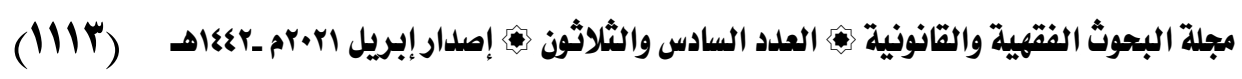

\title{
حق العامل في المعرفة في عقد العمل
}

\author{
الدكتــــور \\ باسر محمد النيداخي \\ مخرسن القانوف المتني \\ مههى الهجمي الهالي للهلوم الإلىارية
}


(IIIE)

حق العامل في المعرفة في عقد العمل 


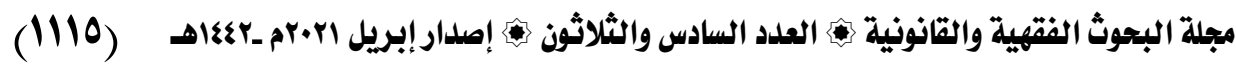
حق العامل في المعرفة في عقد العمل ياسر محمد النيانى. قسم القانون المدني، معهل العجمي العالي للعلوم الإدارية، الإسكندرية، مصر . البريد الإليكتروني: dr.yaser.moh@gmail.com

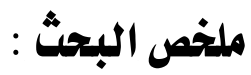
موضوع هذا البحث يدور حول حق العامل في المعرفة في عقد العمل ، حيـث إن علاقة

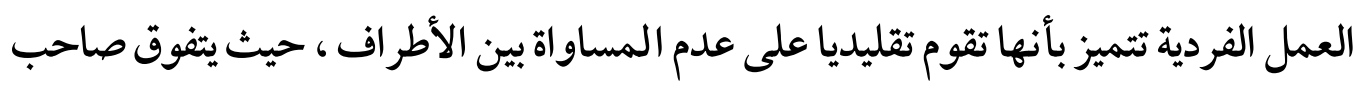

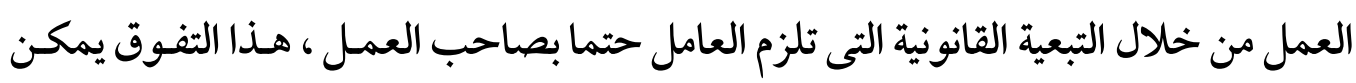

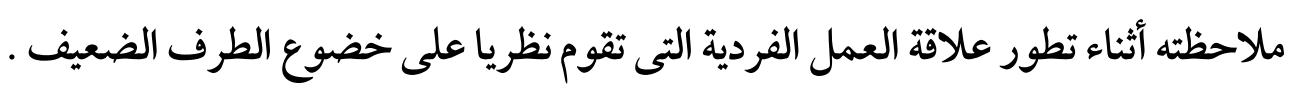

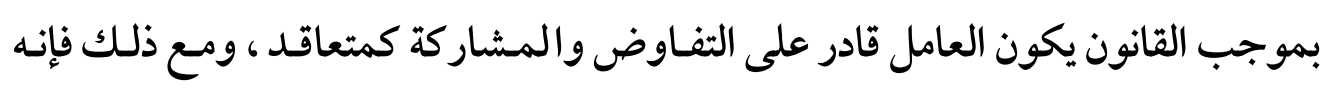
يوجد شك مشروع في حدوث ذلك ؛ يرجع هذا الشك إلى عدم المساواة الأولية بين أطراف

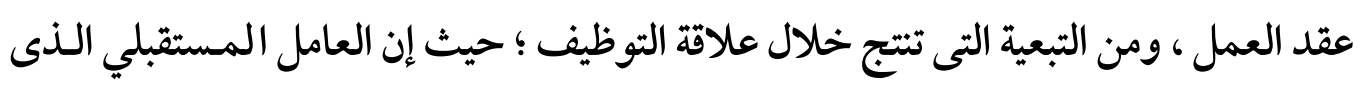

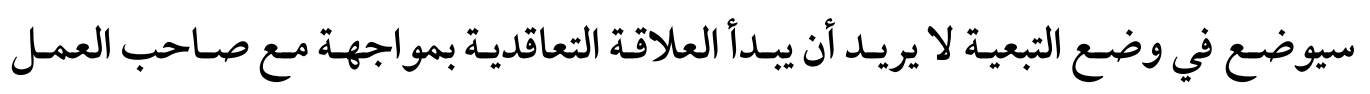
وصاحب سلطة التوظيف .

بسبب هذه القوة التى يتمتع بها صاحب العمل يـتم إنشاء علاقة غير متكافئة بين العامل

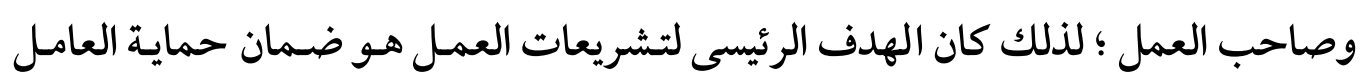
باعتباره الطرف الضعيف ضد إساءة استخدام السلطة المحتملة ؛ وذلك بيناء نظام حمايـة

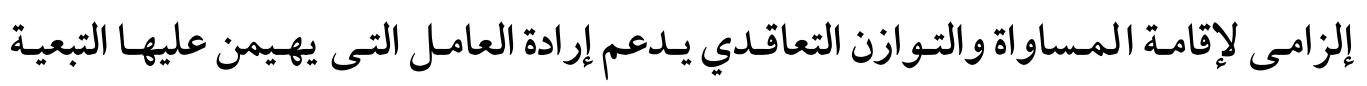

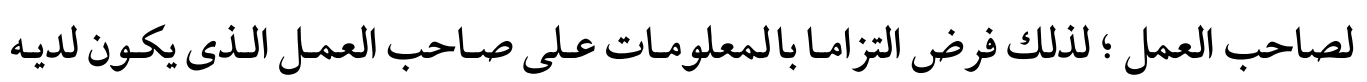

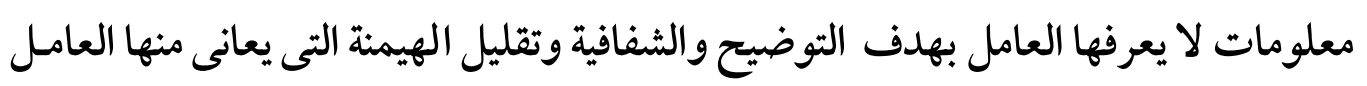
وضمان استعادة المساواة في العقد . 
(III7)

$$
\text { حق العامل في المعرفة في عقد العمل }
$$

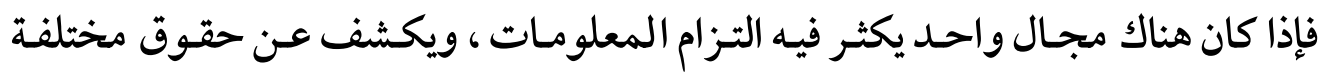

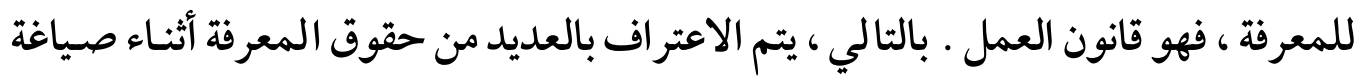

$$
\text { عقد العمل وأثناء تنفيذه و أيضًا أثناء إنهائه . }
$$

الكلمات المقتاحية : عقد العمل الفردى ، حتق العامل في المعرفة ، المعرفة في مرحلة

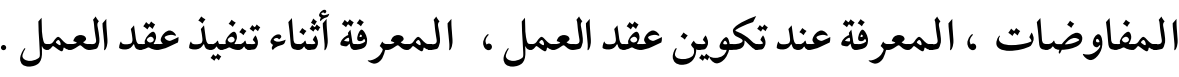




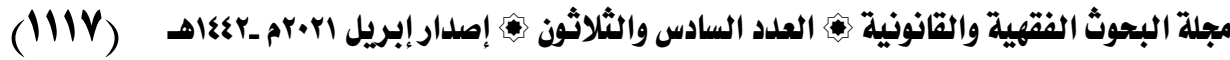

The worker's right to know in the work contract

Yaser Mohamad Elnaydany

Department of Civil Law, Al- Ajami Higher Institute For

Administrative Science, Alexandria, Egypt.

Email : dr.yaser.moh@gmail.com

\section{Abstract:}

The subject of this research revolves around the worker's right to knowledge in the work contract, and since the individual work relationship is characterized by being traditionally based on inequality between the parties, where the worker excels through the legal dependency that inevitably binds the worker to the employer, this superiority can be observed during the development of the work relationship Individualism, which is theoretically based on the submission of the weak party .

Under the law, the worker is able to negotiate and participate as a contractor, however there is a legitimate doubt that this will happen. This suspicion is due to the primary inequality between the parties to the employment contract, and from the dependency that results during the employment relationship; Whereas, the future worker who will be placed in a dependent position does not want to start the contractual relationship with a confrontation with the employer and the employment authority .

Because of this employer power, an unequal relationship is created between the worker and the employer; Therefore, the main objective of labor legislation was to ensure the protection of the worker as the vulnerable party against potential abuse of power; By building a mandatory protection system to establish contractual equality and balance in support of the worker's will, which is dominated by the dependency of the employer; Therefore, imposing an obligation to information on the employer who has information that the worker doesn't know, with the aim of clarity and transparency, reducing the 
(IIIA)

dominance that the worker suffers from, and ensuring the restoration of equality in the contract .

If there is one area where information obligations abound, and reveals the different rights of knowledge, it is the Labor Law . Thus, many knowledge rights are recognized during the drafting of an employment contract, during its execution, and also during its termination .

\section{Keywords:}

Employment Contract Individual, The worker's Right To

Knowledge, Knowledge In The Stage Of Negotiations, Knowledge

When Configuring The Employment Contract, Knowledge

During The Implementation Of The Labor Contract. 


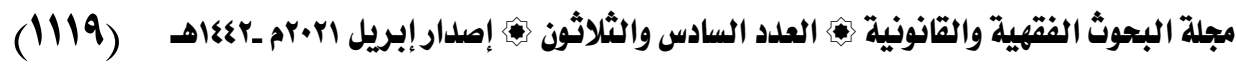

\section{تمهيد}

تستند القواعد التى تحكم تكوين عقد العمل إلى القواعد العامة التى تحكم العقود ، ومـع ذلك فإن هناك بعض الخصوصيات الموجـودة في قـانون العمل والمتعلقـة بمر اعـاة صسحة مو افقة العامل "(1) التى يحكمها ثلاث قو اعد أساسية :

وفقا للقاعدة الأولى فإن تكوين عقد العمل يتم بالقبول أو الموافقة من قبل المستفيد سواء من عرض عقد العمل أو في حالة الوعد بالتعاقد (r). أما القاعدة الثانية المتعلقة بالتعبير عن الموافقة ، فإن عقد العمل يقوم على أساس التوافق

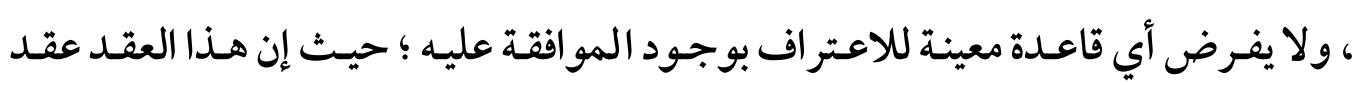
رضائى يكفى تقديم الدليل على وجود الموافقات عليه (م). فعقد العمل عقد رضائى من حيث المبدأ ولا يخضع لأى شكل معين ؛ لذلك يمكن التعبير عن الموافقة بأية وسيلة سواء أكانت المو افقة كتابية أو لفظية (s)

(1)- Martine GOURVES épouse BARBIER, La volonté du salarié dans le rapport de travail, These, Université Lumière Lyon 2, 2010, p.114.

(Y) - فإذا أصدر المستفيد من العرض قبو لا مبـدئيا ولكنه كـان مقترناً بتحفظـات و شروط خاصسة ، في

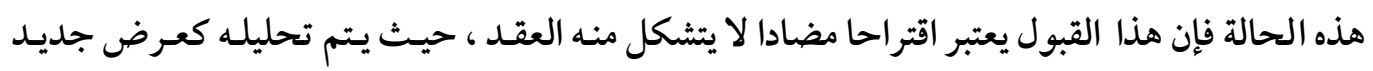

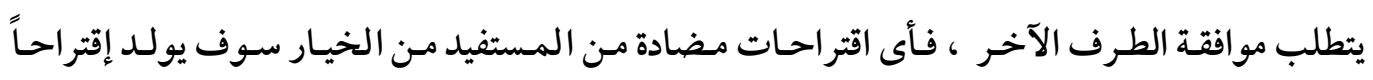

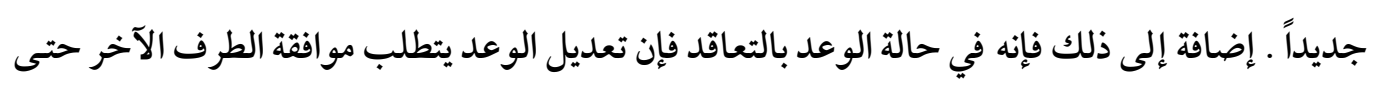

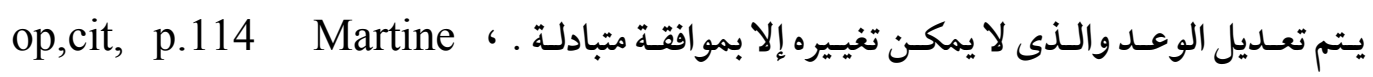
GOURVES

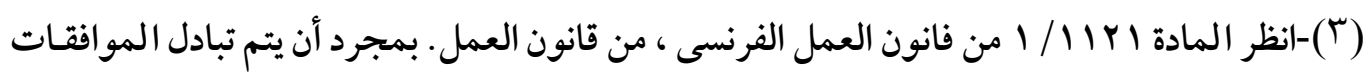

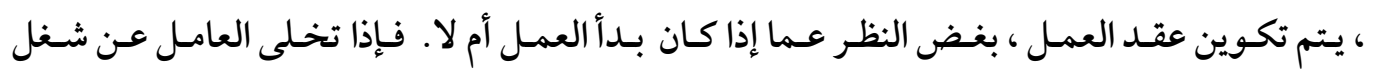

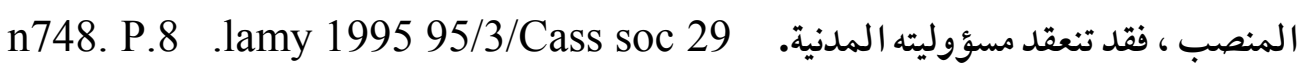
(ع)-يمكن التعبير عن الموافقة بأى مظهر لا يترك أى شـك أو اجتهاد لتفسير هـذا المظهر ؛ لـذلك فئإن

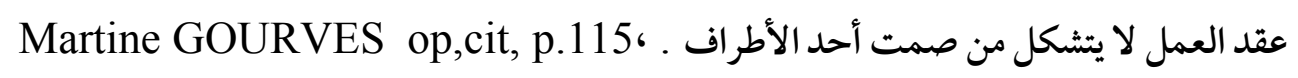


(IIr.)

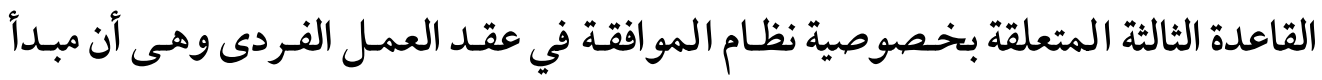

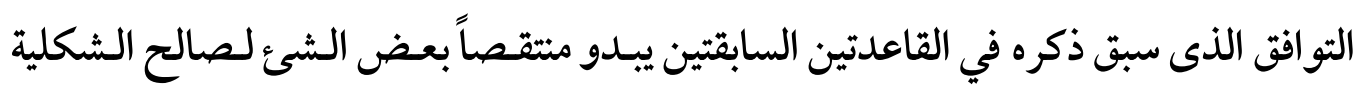
الآخذة في التوسع بسرعة (1) والتى تهدف إلى جذب انتباه المتعاقد نحو نطاق التزاماته ، كما تضمن صحة الارتباط التعاقدى . تصن.

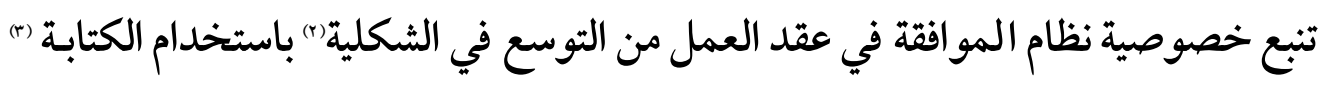

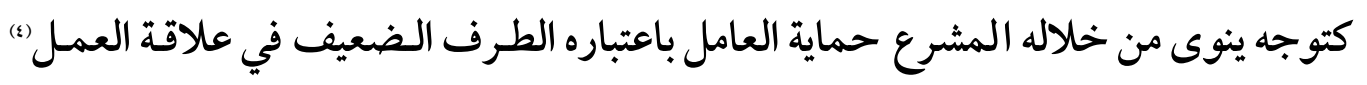

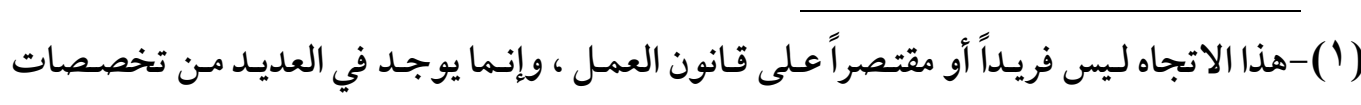

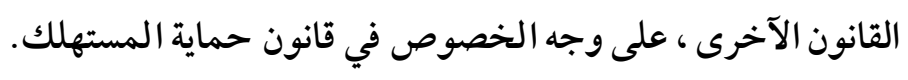

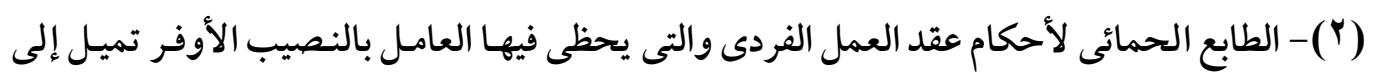

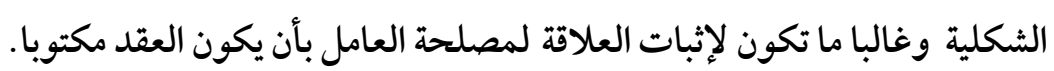

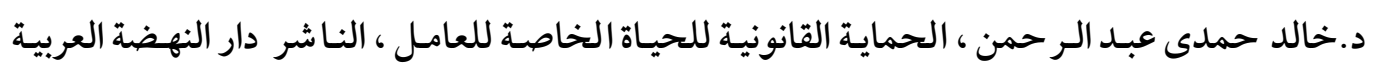
.

(3)-Martine GOURVES op , cit, p. 115

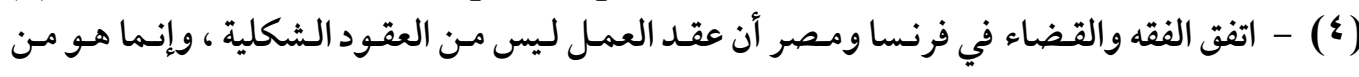

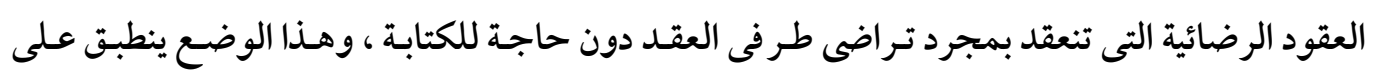

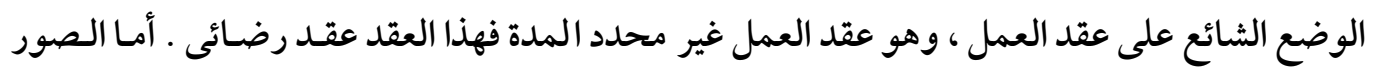

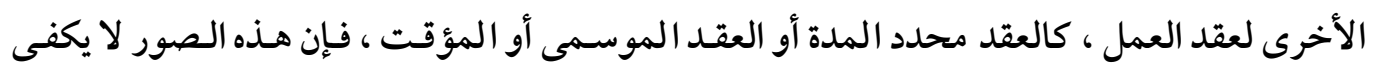

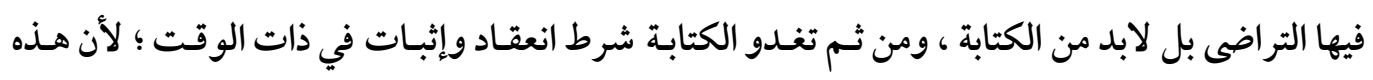

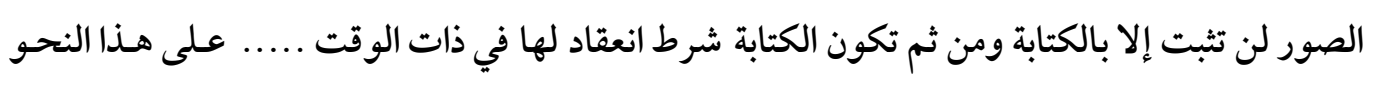

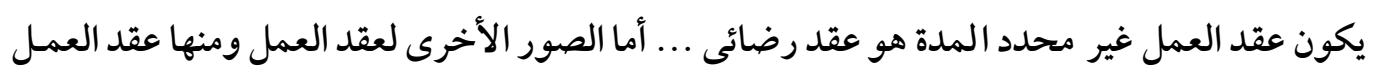

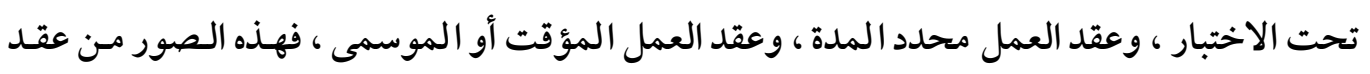

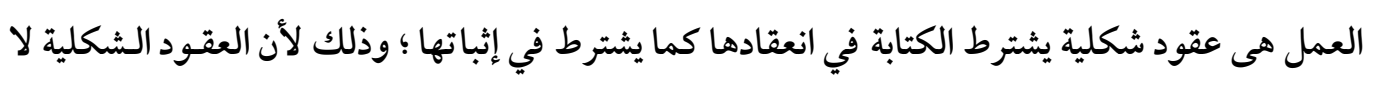

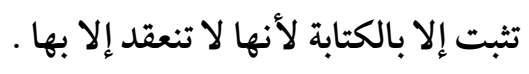




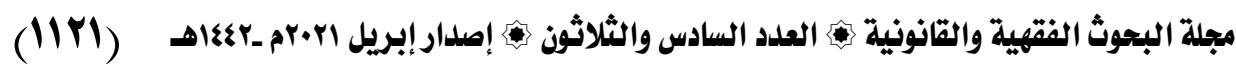

ومن إقرار التزام المعلومات الذى يقع على عاتق الطرف المهيمن (1) ؛ وذلك لتنوير الطرف

$$
\text { الأخر حتى يستطيع تحديد استصواب إبر ام العقد من عدمه (r) . }
$$

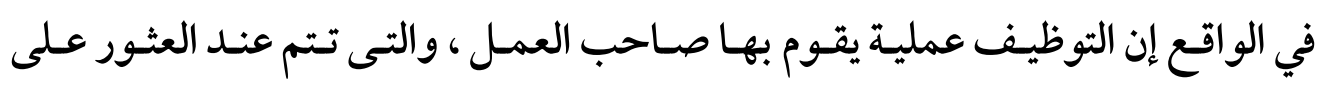
الأشخاص الذين من المحتمل أن يشغلوا الوظائف المتوفرة في منشأته واختيـار الأنسب منهم ويتم التوظيف من خلال عقد العمل الذـى يعتبر وسـيلة للحصصول عـلى الوظيفـة بالنسبة للعامل ، ووسيلة لملء الوظيفة بالنسبة لصاحب العمل ، وهـذا يعنى أن التوظيف يتم عند

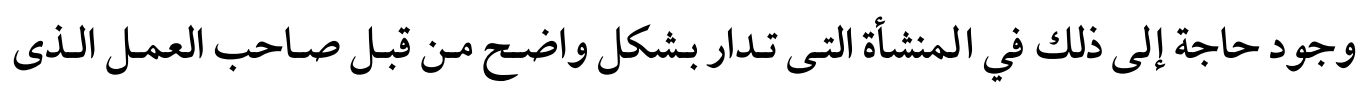
ينظمها ويؤسس وحداتها المختلفة)

د. محمد مصطفى غــازى زيـدان ، دور القـاضى في تحقيتق التوازن في عقـد العمل ، دراسـة مقارنة بين

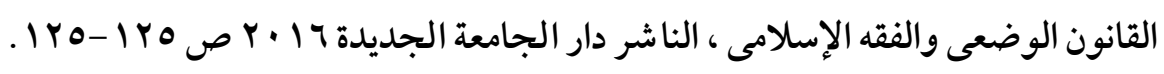

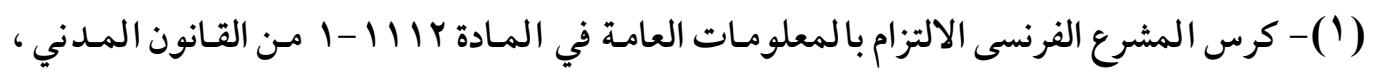
بحيث يكون لها أساس نصي خاص بها. كما أنها الآن منفصلة تمامًا عن الأسس القانونيـة الأخرى التي كانت مرتبطة بها تقليديًا - كان يتم ربط الالتزام بالمعلومـات العامـة مـن خـلال السوابق التضائية بمبـدأ

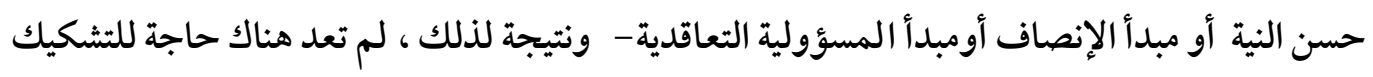

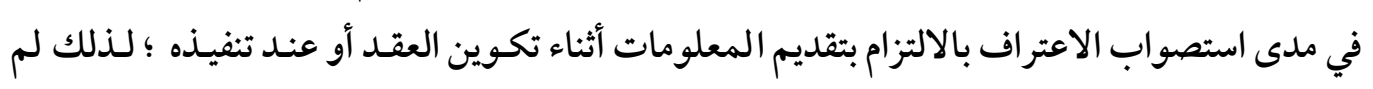

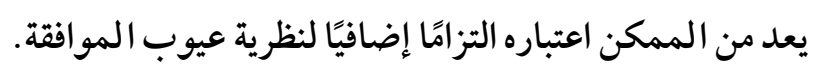
يُفرض الالتزام بالمعلومات الآن في جميع الظروف: تم تأسيسه كمبدأ أساسي في قـانون العقود ليشمل (2)- Martine GOURVES ,op , cit, p. 125 جميع العقود.

(3)- J. PELISSIER. G. AUZERO et E. DOCKES, Droit du travail, Précis Dalloz, 2013, p. 161

(4)- Léa Amic, La loyauté dans les rapports de travail, THÈSE, Université d'Avignon, 2014. p .388 Objet 540 
$(11 Y r)$

فمبادرة إبر ام عقد العمل واختيار العامل تنتمى إلى صاحب العمل صاحب القوة الواقعية

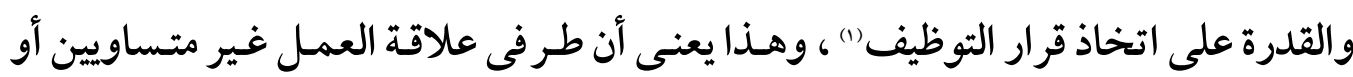

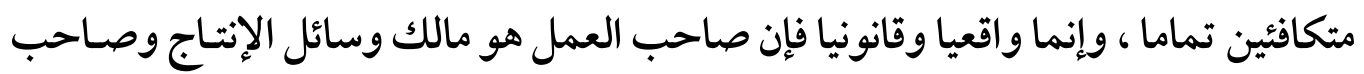
قرار التوظيف (م).

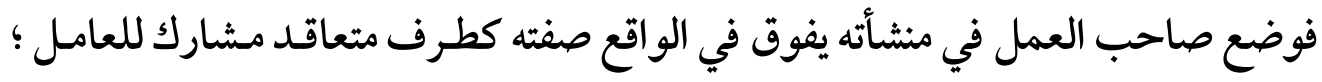

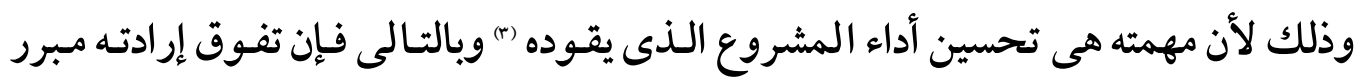
بالكفاءة التى تحفزها صفته ، والتى تضمن لصاحب العمل التعبير عن إرادته واحتر امها في

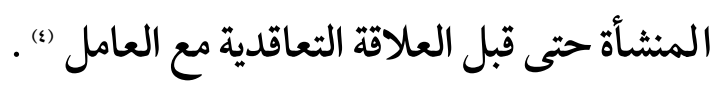
بموجب القانون يكون العامل قادراً على التفاوض والمششار كة كمتعاقـد ، ومـع ذلك فئل فإنه يوجد شك مشروع في حدوث ذلك ؛ يرجع هذا الشك إلى عدم المساواة الأولية بين أطراف

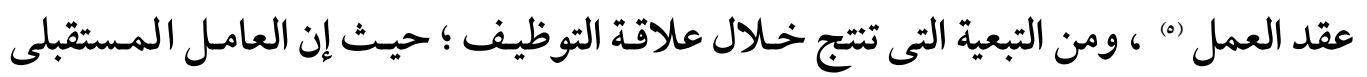

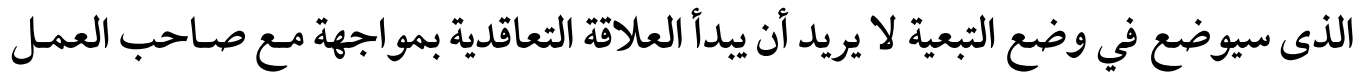

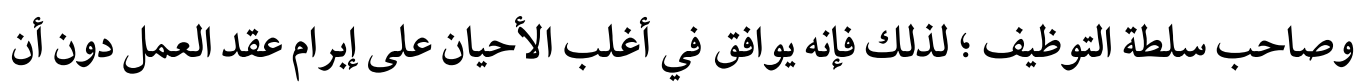

(1)- Martine GOURVES ,op , cit, p. 125 Objet 56

(2)- Léa Amic, op, cit , p.388 Objet 541

(3)- M.A. PEANO, Lřintuitus personae dans le contrat de travail, Dr. soc. 1995, n 2, p. 129- Léa Amic, op, cit, p.390 Objet 544

(4)- Léa Amic, op, cit , p.390 Objet 544

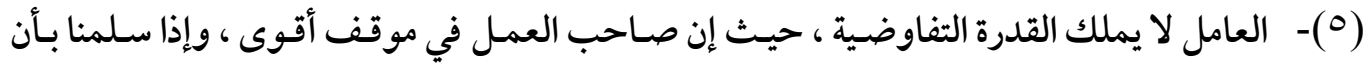

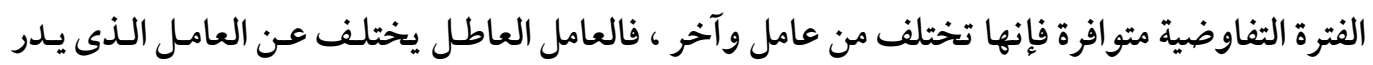

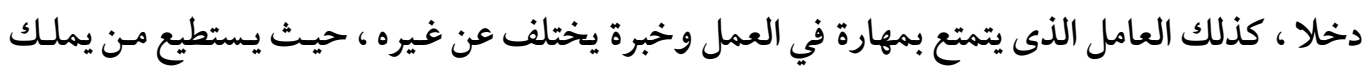

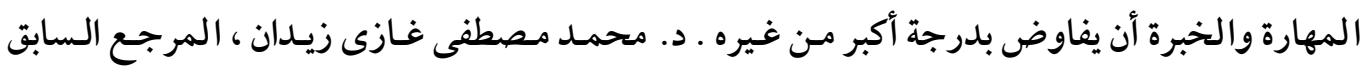




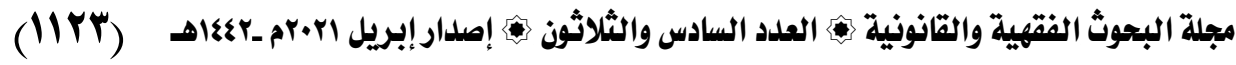
يكون قد قام بالتفاوض على هذا العقد (1). بسبب هذه القوة التى يتمتع بها صاحب العمل يـتم إنشاء علاقـة غير متكافئة بـين العامل وصاحب العمل ، حيث إن القوة تعتبر بالضرورة قيدا على العامل الذى يخضع لها ؛ لـذلك كان الهدف الرئيسى لتشريعات العمل هو ضمان حماية العامل باعتباره الطرف الـيفيف(r) ضد إساءة استخدام السلطة المحتملـة (r) وذلك بينـاء نظام حمايـة إلزامى لإقامـة المساواة والتوازن التعاقدى(s) بدعم إرادة العامل التى تهيمن عليهـا التبعيـة لـصاحب العمـل (o)؛ لـذلك فرض التزاما بالمعلومات والذى يلقى بثقله على الطرف المتعاقـد المهيمن ، و يهـدف إلى

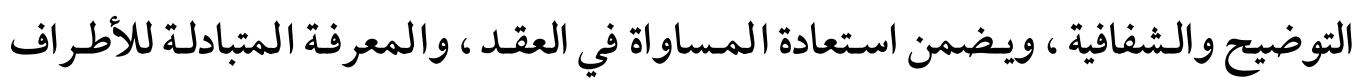
والضرورية للتعبير عن إرادتهم ورغباتهم و الوفاء بالالتزامات المتفق عليها() .

(1) - Martine GOURVES ,op , cit, p. 22 Objet 46

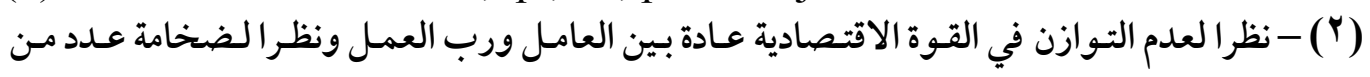

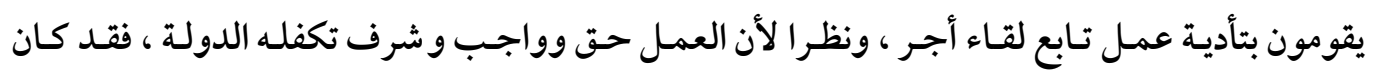

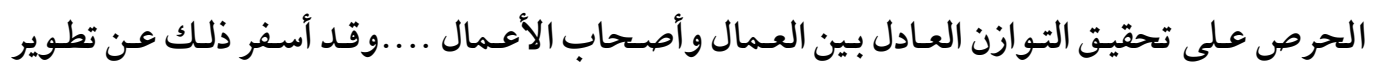

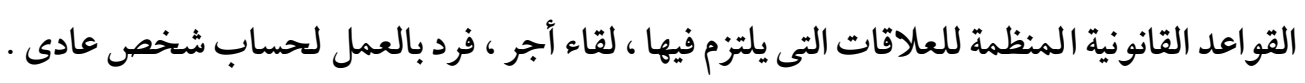

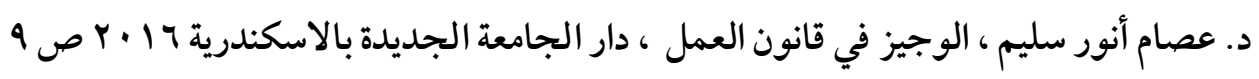
(3)-Martine GOURVES ,op , cit, p. 18 Objet 35

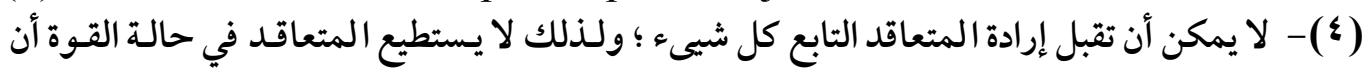

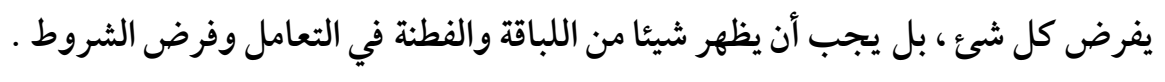
Martine GOURVES ,op , cit, p. 12 Objet 17 (•) - عـن طريـق تعيسين الحـدود القانونيـة في سـلطة صـاحب العمـل وإنـشاء الـضوابط والتوازنـات

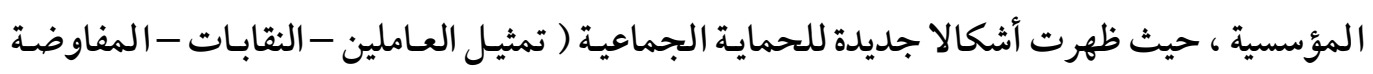
الجماعية )

(6) - Martine GOURVES ,op , cit, p. 12 Objet 16 
(IIrs)

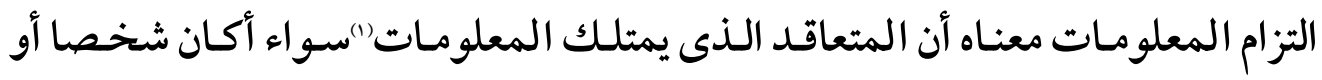
مؤسسة أو سلطة يجب عليه أن يبلغ بها المتعاقد الآخر.

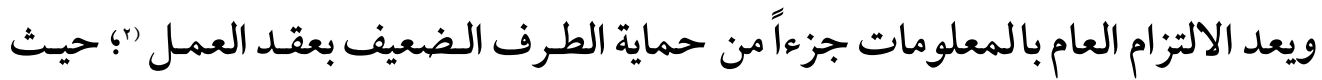
يمكنه من الحصول على أفضل معرفة بالسياق التعاقدى وإعطاء الموافقة المستنيرة الكاملة

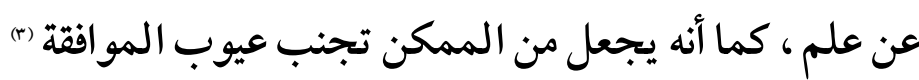
فالمعلومات لا تلغى إرادة المتعاقد ، بل على العكس تعزز التفكير من خـلال التواصل

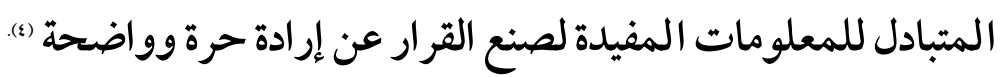

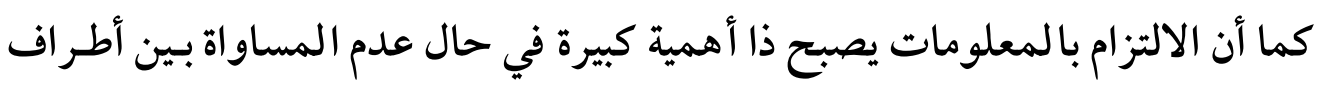

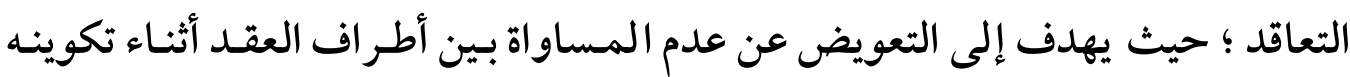
وذلك لصالح العامل (م) باعتباره الطرف الضعيف ، حيث يدعمه بشكل كبير في التعبير عن

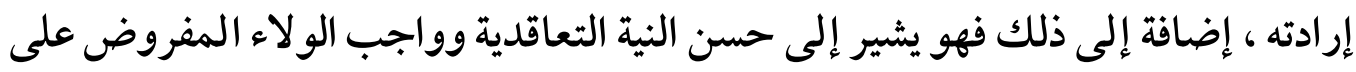
طر فى عقد العمل سواء في مرحلة ما قبل التعاقد أو في حال إبر ام عقد العمل (1)، كما أنه إنه يدعم فكرة التعاون بين المتعاقدين حيث إنه النزام يثقل كاهل طر في عقد العمل (v) ولكن

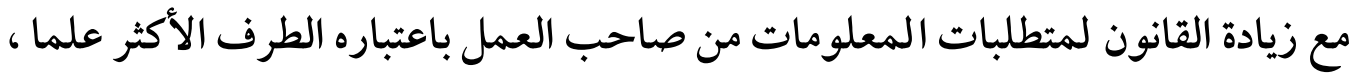

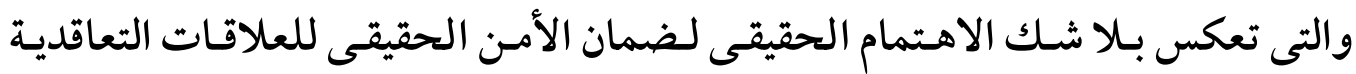

سواء أكان المتعاقد هو الشخص الوحيد الذى يعرفها أو في وضع أفضل لمعرفتها أو على الأقل

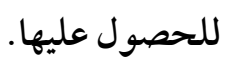

(2)- Martine GOURVES ,op , cit, p. 125 Objet 247

(3)- Ibid

(4)- Ibid, Objet 248

(5)- Ibid

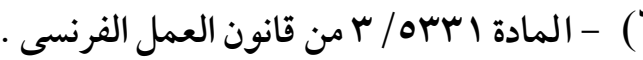

(7) - A.Lepage, Avant-propos à l'étude Le droit de savoir, Rapport annuel de la Cour de cassation 2010, La Documentation française, 2011. 


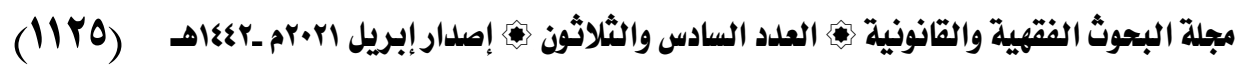
الفردية(1) ويعكس في نفس الوقت تطور الشكلية الإعلامية() الحساضرة وبشـدة في قـانون العمل (r) ( )

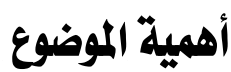

نظر الأهمية المعلومات في عقد العمل كأحـــ أهــم العقود في عصرنا الحـالى ، ونظرا

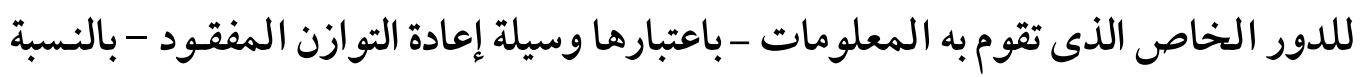

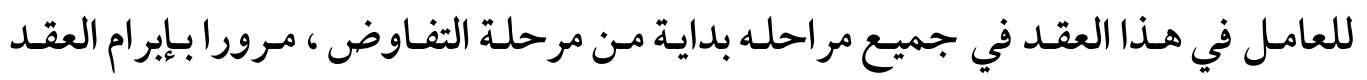

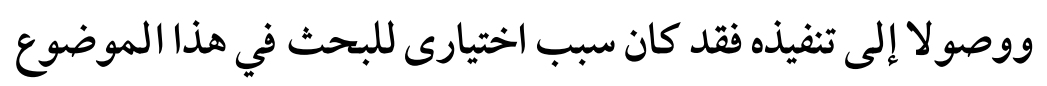

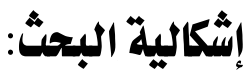

ومن هذا المنطلق فإن إشكالية بحثنا يمكن طرحها كما يلى : مـا هـو أثر حق العامـل في

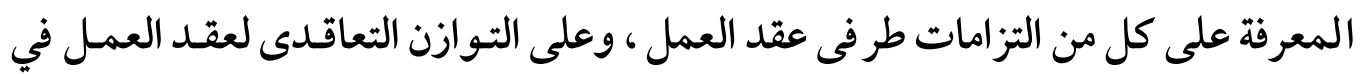

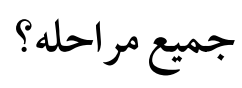

\section{منهج البحث:}

وقد اعتمـدنا في دراستنا على المـنهج التحليلى الوصفى إضـافة إلى المـنهج المقـارن،

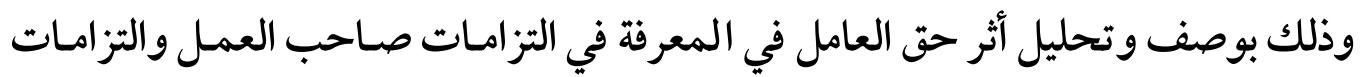

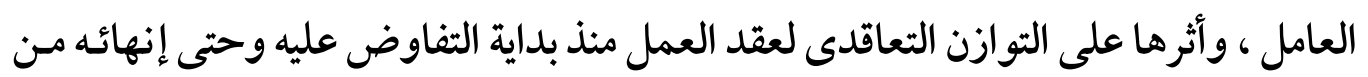

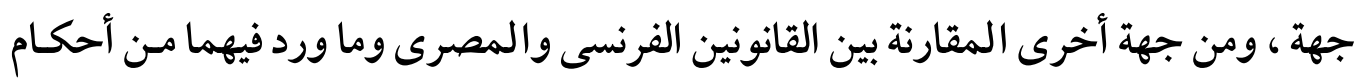
تتعلق بهذا الموضوع.
(1)- Martine GOURVES ,op , cit, p. 126 Objet 251.
(2)- Martine GOURVES ,op , cit, p. 127 Objet 251
(3)- A.Lepage ,op,cit,p.141 
(11rq)

حق العامل في المعرفة في عقد العمل نطاق البحث:

سيقوم الباحث في هذا البحث بطرح مسائله المتعلقة بموضوع حق العامل في المعرفة من

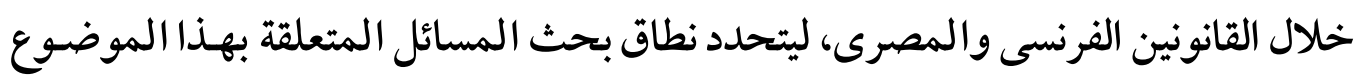
في هذين القانونين من خلال دراسة تحليلية مقارنة.

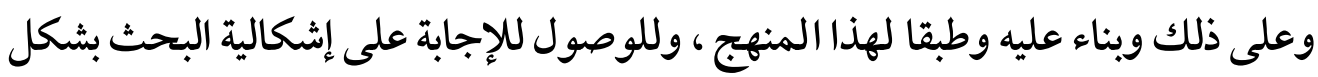
علمي، فإنه سيتم التطرق إلى تناول هذا الموضوع. وقد اقتضت الإجابة على إثـكالية البحـث التطرق إلى تنـاول هـذا الموضـوع في ثلاثة

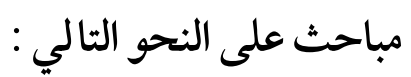
المبحث الأول : حق العامل في المعرفة في الفترة قبل التعاقدية

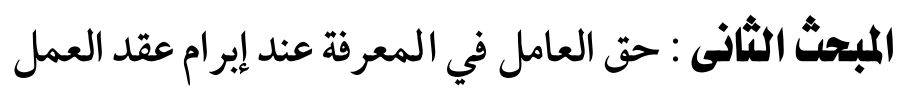
المبحث الثالث : حق العامل في المعرفة أثناء تنفيذ عقد العقد. 


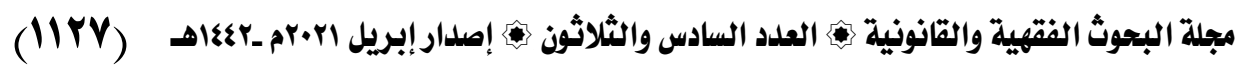

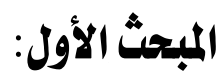

\section{حق العامل في المعرفة في الفترة قبل التعاقدية}

يختلف عقد العمل عن الكثير من العقود الأخرى في أنه يعتبر موضع اهتمام ليس فحسب في المبل منذ انعقـاده ، وخـلال قيامه إلى حين انقضائه ، ولكنه يسبق بإعـداد له . فعلاقـات العمـل

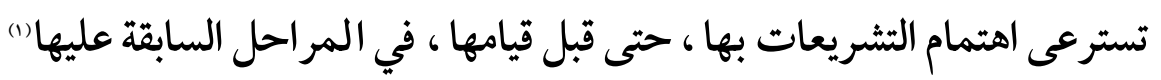

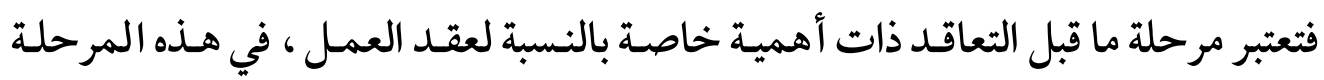

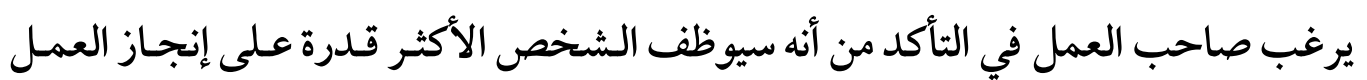

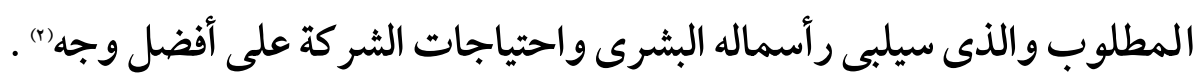
عندما يعرض صاحب العمل وظيفة ما من خلال إعلان مفتوح للجمهور فهذا يعتبر عرضا للدخول في المفاوضات السابقة للتعاقد .

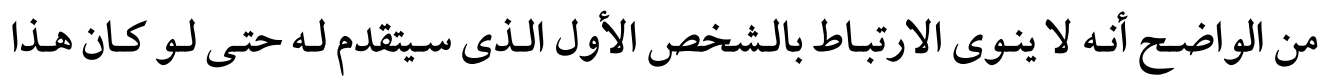

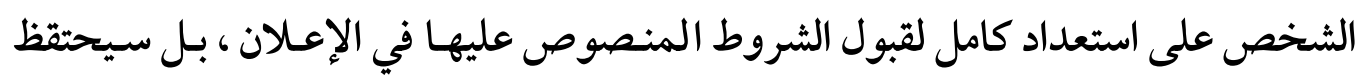
بالحق في الموافقة على الطرف المتعاقد معه (r).

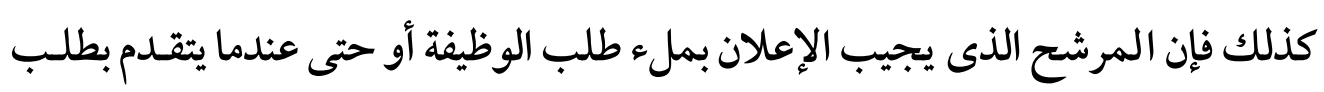
تلقائى إلى صاحب العمل المحتمل فإنه ينوى فقط عرض مهار اته وخبر اتهـ العان.

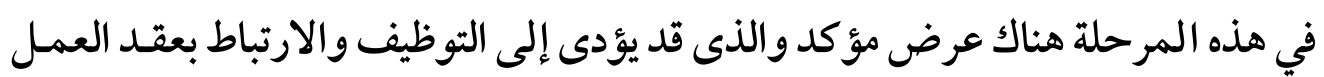
أو الحصول على وعد بالتوظيف.

الطيعة التالة - د. توفيق حسن فرج ، قانون العمل الجديد ، تنقيح وائل بندق ، النا شر مؤسسة إبراهيم الناحل ،

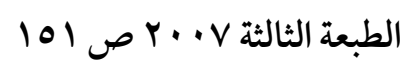

(2) - Marie-Annick PÉANO, L'intuitu personae dans le contrat de travail, Dr.soc. 1995, p. 130

(3) - Martine GOURVES ,op , cit, p. 29 Objet 63 
(11rA)

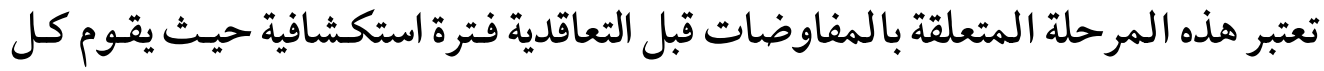

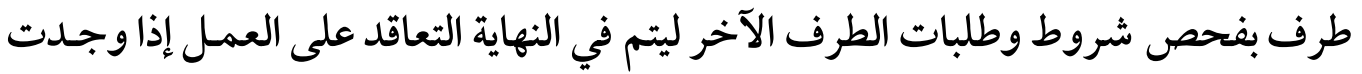

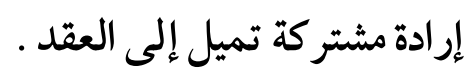

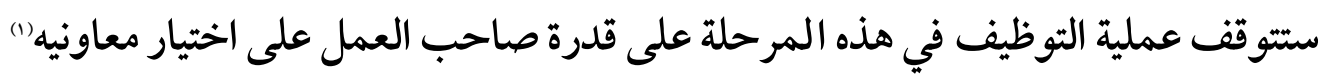

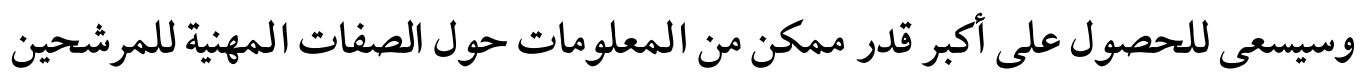

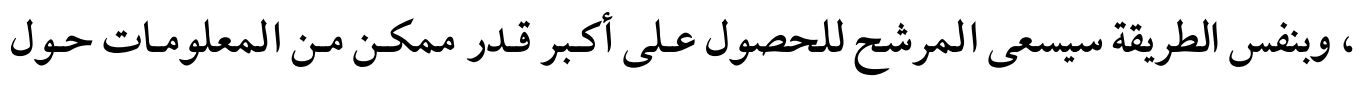

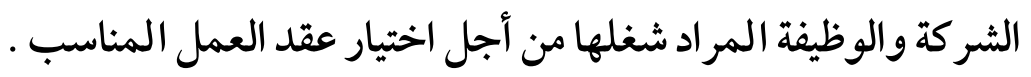

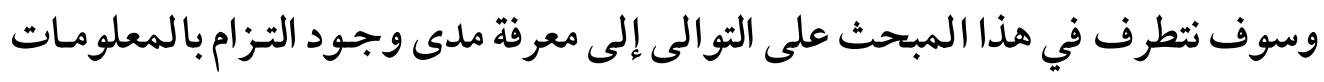

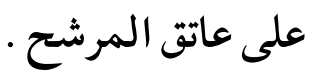

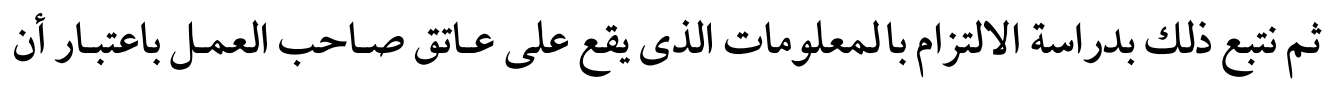

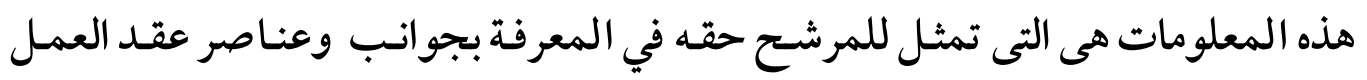
المقبل عليه.

\section{اـ علدم وجود التزام بالمعلومات على عاتق المرشح للتوظيف}

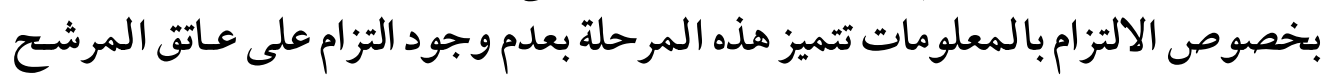

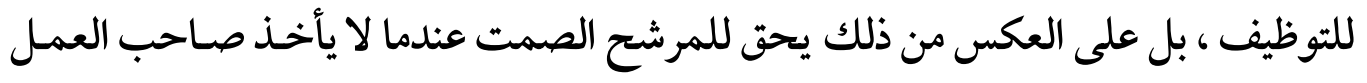
زمام المبادرة للحصول على المعلومات ().

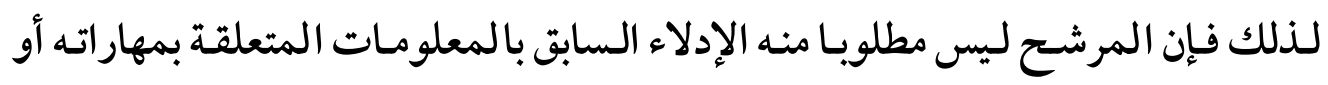

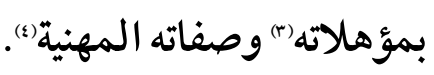

(1) - Cons. const., 20 juillet 1988, Dr.soc. 1988, p. 762

(2) - Martine GOURVES ,op, cit, p. 35 Objet 72-Léa Amic, op, cit, p.406 Objet 578- J. MOULY, note sous Soc. 3 juil. 1990, D. 1991, p. 507 , (3) - J. MOULY, note sous Soc. 3 juil. 1990, D. 1991, p. 507

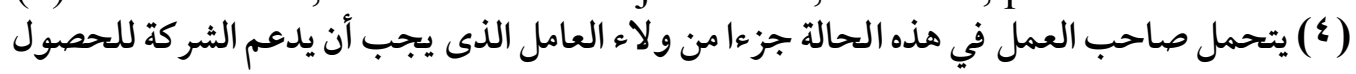

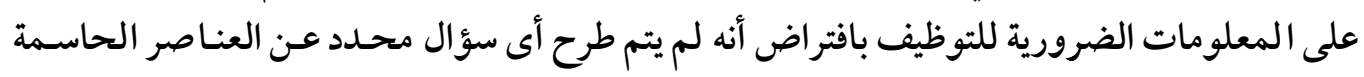
المتنازع عليها والذى يستبعد بشكل فعال الأسئلة الضمنية.

Léa Amic, op, cit , p.411 Objet 588 


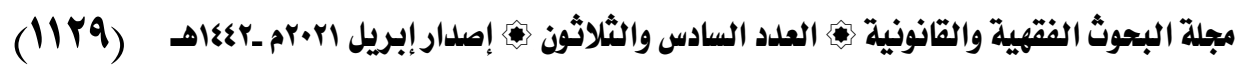

ومع ذلك فيوجد استثناءات نـادرة عـلى هـذه القاعـدة حيـث لا يستطيع المرشـح أن يبقى صامتا ، وإنما يلتزم بإبالاغ صاحب العمل وذلك عند وجود الالتزام بعدم المنافسة الذى يلزمه به صاحب عمل سـابق ( وتعـد هـذه المعلومـة حتميـة ونتيجـة للسو ابق القضائية المستثقة لمحكمة النفض )(") وسوف يكون إحجام المرشح احتيالا وفقا لالتزام المعلومات() . كذلك الحال تسقط الثرعية من صمت المرشح فيما يتعلق بوجـود عقد تمثيـل حصرى

$$
\text { مبرم مع صاحب عمل سابق(r) . }
$$

باستثناء هاتين الحالين الخاصتين لا يتعين على المرشح للعمل توفير معلومات غير مطلوية

منه حتى لو كان يعلم بإمكانية إحداث الصمت للأثر البالغ في تعديل قرار صاحب العمل (s) .

لذلك يجب على صاحب العمل المبادرة للتعرف على شخصية المرشح وصفاته المهنيـة (o)،

فيستطيع صاحب العمل في هذه المرحلة أن يطرح أسـئلة على المرشحح تكون مرتبطة ارتباطسا وثيقا بالوظيفة المراد شغلها).

بشكل عام يجب على أى مرشح أن يستجيب بحسن نيـة للأسئلة التى يطر حها صـاحب العمل (v) وذلك عندما تكون ذات صلة بتقيم الصفات المهنية للمرشح أو تستند إلى بيانـات موضوعية تتعلق به (1) - مولمد

(1)- Soc. 3 janv. 1964, JCP éd. G. 1964, II, 13551, note R. LINDON ; D. 1964 , p. 215 ; Soc. 10 févr. 1965, JCP éd. G. 1965, II, 14181, note G.-H. CAMERLYNCK- Soc. 23 mars 1977, Bull. civ. V, n 227-. Soc. 14 déc. 1983, Bull. civ. V, n 618 ; CA Versailles, 29 juin 2000, Y.

(2) - Léa Amic, op, cit , p.408 Objet 581

(3) -CA Riom, 13 mars 1989, RJS 1989, n 817 ; Gaz. Palais 1990, I, Somm., p.101.

(4) - Léa Amic, op, cit , p.408 Objet 582

(5) - Ibid, Objet 590

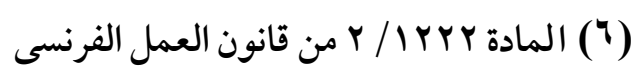

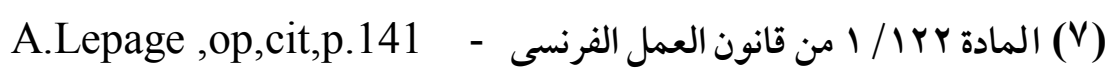
(8)- A.Lepage ,op,cit,p.141 
(11\%॰)

عندما يتلقى صاحب العمل المعلومات الإيجابية من المرشح فإنه ملتزم بالاستفسار عن فئن

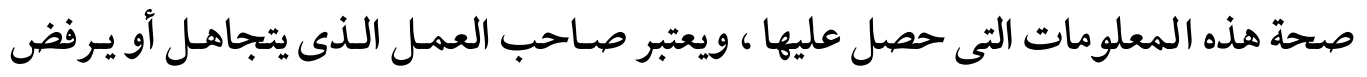

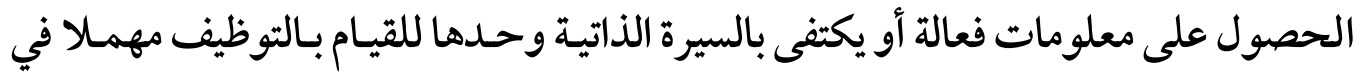
حق نفسه مرتكبا لخطأ لا يغتفر (1) ومسئو لا عن اختياره" (1) .

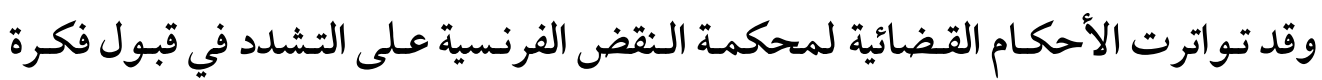
التوصيف الاحتيالى للبيانات الكاذبة المقدمة من المرشح، وعدم افتر اض الاحتيال(ه) ، حيث

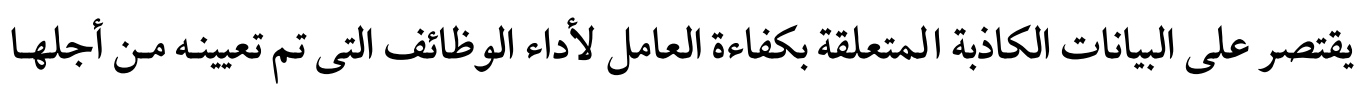

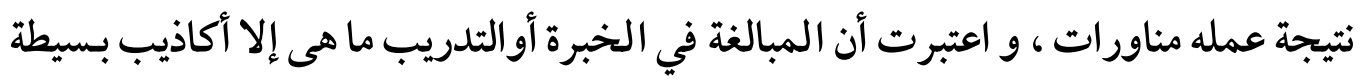

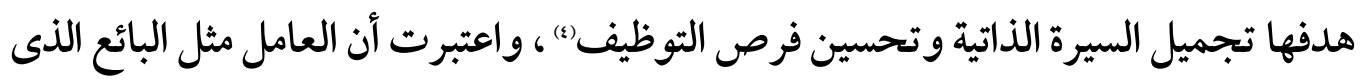
يمدح بضاعته ويرى أن التلاعب في العرض التقديمى الخاص بمهار اته سيكون أكثر جاذبية واهتمام من صاحب العمل ، مثله في ذلك مثل صاحب العمل الذى يثنى على مزايـا الوظيفة

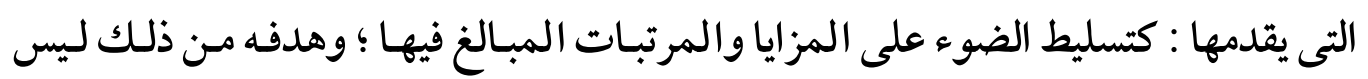

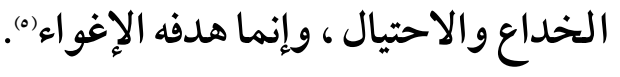

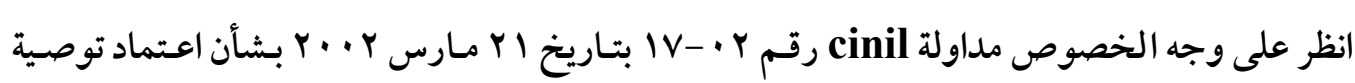

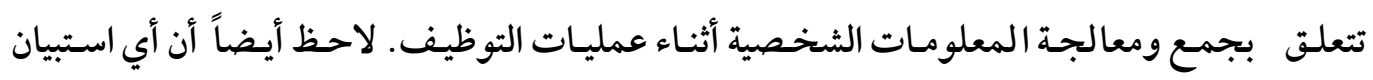

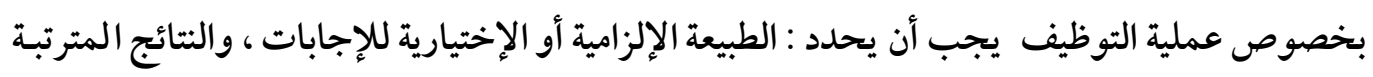

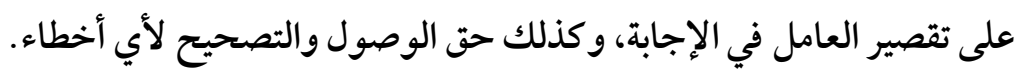

(1)- Léa Amic, op, cit , p.417 Objet 601

(2)- CA Poitiers, 4 mars 1986, Bull. soc. Lefebvre, 1986, p. 481, n 1270

(3)-Grégoire LOISEAU, La neutralisation $d u$ dol du salarié, D. 2006, p. 204 - Cass. soc., 21 septembre 2005, n ${ }^{\circ} 03-44.855$, Bull. civ. V, n $262-$

(4) - Cass. soc., 16 février 1999, no 96-45.565, Bull. civ. V n 74

(5) - Léa Amic, op, cit , p.416 Objet 597 


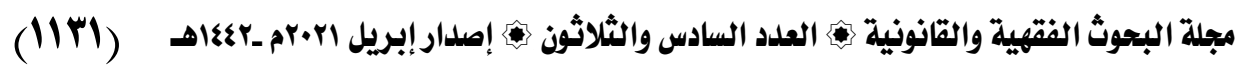

كذلك الحال فإن صاحب العمل ملزم باحتر ام خصوصية المرشـح (1) عند قيامه بـالتحقق من صحة أقو اله ، فيحق للمرشح عدم الإجابة التى تعتبر خـارج النطاق التعاقدى (r) ؛ فيجـب

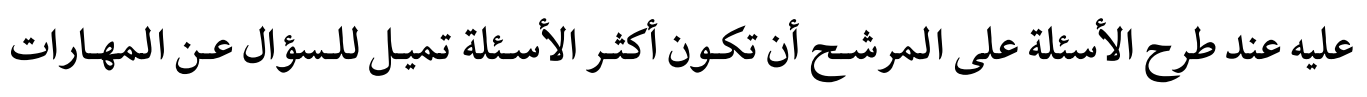

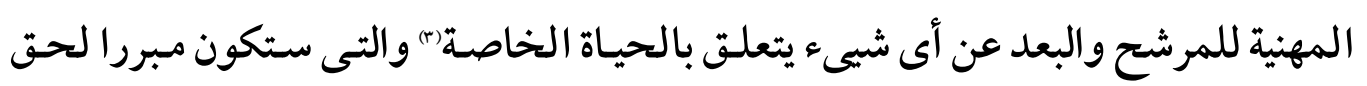

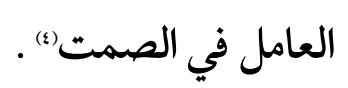
فإذا كان الطبيعى أن صاحب العمل يريد الحصول على أكبر قدر ممكن مـن المعلومـات عن المرشح الذى يخطط لتعيينه ، فيعمل على التنقيب عـن المرشـح الأكثر كفـاءة والأكثر

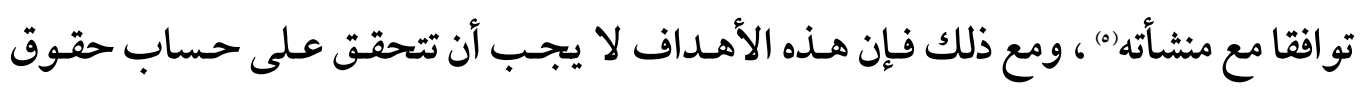

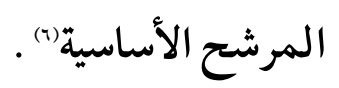

فالمعلومات المتصلة بالحياة الخاصة أو العائلية لا يمكن أن يطلبها صاحب العمل ، كما لا يمكن له التدخل في القرار ات المتعلقة بها ؛ لذلك لا يعد احتيالا من المرشح عدم الإجابة على هذه الأسئلة أو حتى الإجابة الخاطئة عليها ؛ وذلك لأن السؤال في حد ذاته غير شرعى لهن

(1) - لا يجـوز المـساس بالحيـاة الخاصـة أو بحريـة المتقـدمين بحجـة التأكـد مـن صـلاحيته لـشغل

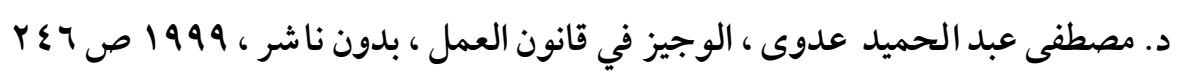

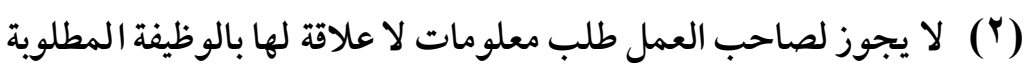

Martine GOURVES ,op , cit, p. 36 Objet 73

(r) - الاقتراب مـن الحيـاة الخاصـة في مجـال علاقـات العمـل مقيـد بأحكـام القـانون ، خاصـة إذا كنـا

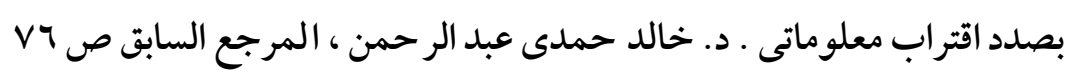

(4)- Martine GOURVES ,op , cit, p. 36 Objet 73

(5)- Léa Amic, op, cit , p.424 Objet 617

(6)-Ibid

(7)- Martine GOURVES ,op , cit, p. 36 Objet 73 
$(11 r r)$

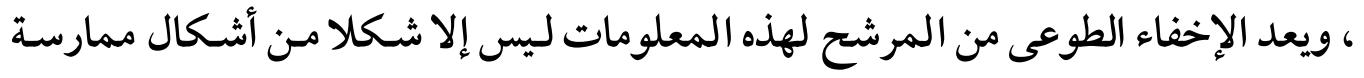
الحق في احتر ام الحياة الخاصة للمرشح للعمل.

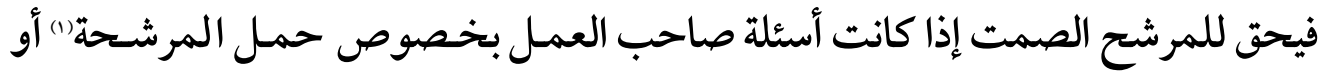
بخصوص مسائل الخطوبة والزواج() ، أو بخصوص المعتقدات الدينية أو السياسية للمرشح

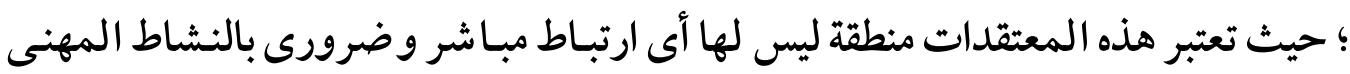
للمرشح ، ويعد السؤال عنها يسيىء إلى مبدأ احتر ام الحياة الخاصة"). ومع فإنه إذا كان من غير الممكن السؤال عن الحياة العائلية والخاصـة للمرشـح ؛ لعـدم

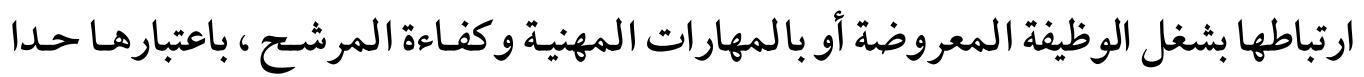

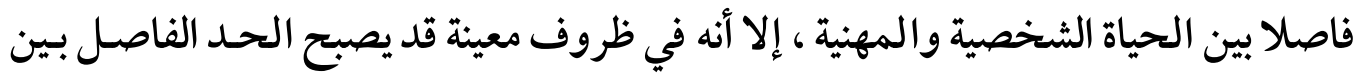

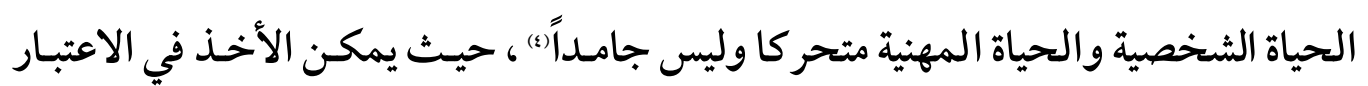

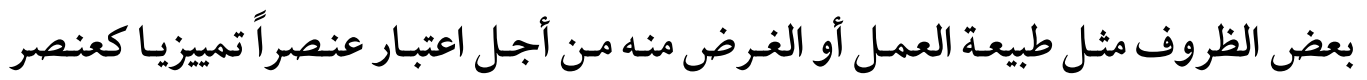

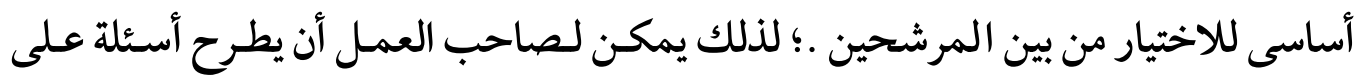
المرشح تتعلق بشخص المرشح وحياته الخاصة وليس فقط بخصوص صفاته المهنية. . .

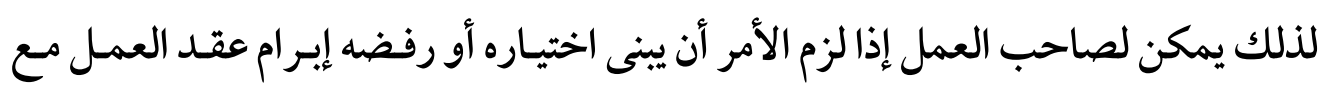

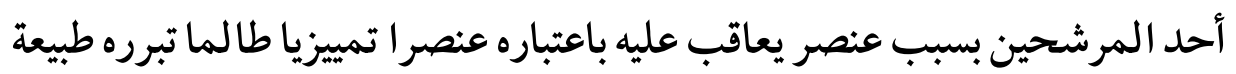

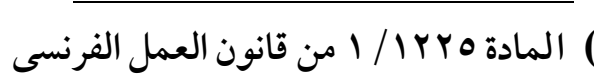

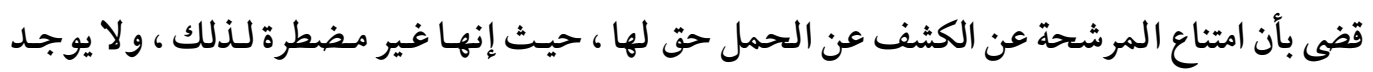

$$
\text { خداع أو سبب لتذرع صاحب العمل بوجود عيب في الموافقة يمنع تكوين العقد. }
$$

Soc. 23 févr. 1972, Bull. civ. V., n 152 , p. 143.

(2)- Léa Amic, op, cit , p.426 Objet 621- Soc. 17 mars 1971, Bull. civ. V, $\mathrm{n}^{\circ} 216$.

(3)- Léa Amic, op, cit , p.425 Objet 620

(4) - Soc. 13 mai 1969, JCP éd. G. 1970, II, 16208, note J.-M. VERDIER ; Soc. 17 oct. 1973 , JCP éd. G. 1974, II,

(5) - Cass. Ass. plén. 19 mai 1978, D. 1978, p. 541 


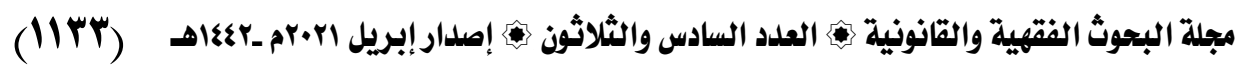

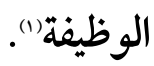

إذن لا يزال من الممكن لصاحب العمل طرح أسئلة مختلفـة بـشأن الصلة بـين العنـاصر المحمية ( سواء أكانت خاصة أو تمييزية ) وبين الوظيفة المحمية)(م) .

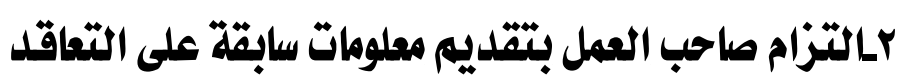

من ناحية أخرى فإن صاحب العمل ملتزم بتقديم معلومات مسبقة إلى المرشح للتوظيف، تكون متعلقة بالوظيفة المقترحة وشروط العمل (r). تعمل هذه المعلومات على تعزيز عملية صنع القرار لدى المرشح ، حيث تظهر المعرفة بالسياق و القضايا في أية عملية صنع قرار حاسمة للاختيـار المستنير ، لاسيما عندما يكون متخذ القرار في وضع غير متكافئ يتميز بالتبعية ؛ لذلك في عقد العمل يخضع قرار المرشح للتعاقد للدعم من خلال المعلومات المقدمة من صاحب العمل للمتقدمين للوظيفة") . إن الالتزام بتقديم المعلومات لصالح المرشح يدعمه بشكل كبير في تعبيره ، إضـافة إلى أنه يشير إلى حسن النية التعاقدية ، ويشكل واجـب الولاء المفـروض عـلى كل مـن الدائن والمـدين في الحـالات التعاقديـة وبخخاصـة في الفـترة الـسابقة عـلى التعاقـد حيـثـ تـساهم المعلومات بلا شك في إعادة التوازن التعاقدى لصالح المرشح.

(1) - في بعض الحالات الاستثنائية للغاية التى تقتضى الضرورة في بعض الوظائف التعاقد على أسـاس

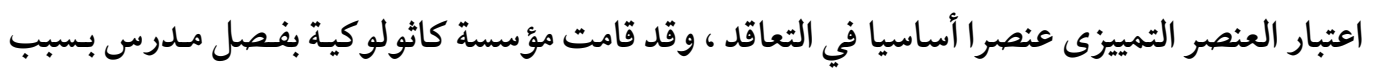

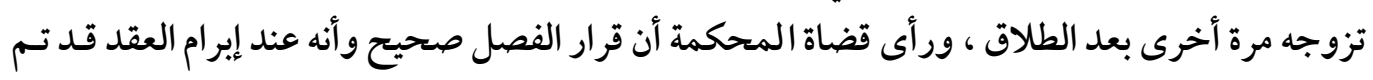

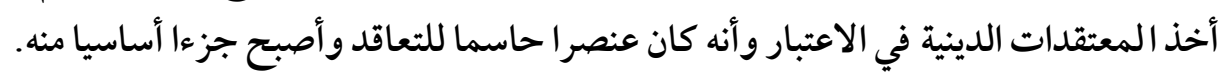
Ass. plén. 19 mai 1978, n 76-41211, Bull. civ. 1978, n"1, p. 1.

(2)- Léa Amic, op, cit, p.430 Objet 628

(3)- Ibid, Objet 579

(4)- Martine GOURVES ,op , cit, p. 38 Objet 77 
(11rs)

في البداية يجب على صاحب العمل أن يقوم بتوفير معلومات كافية عـن الوظيفة المـراد

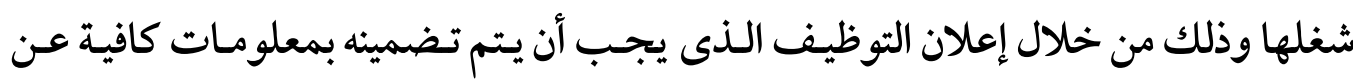

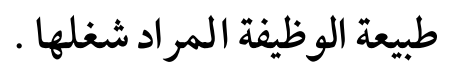

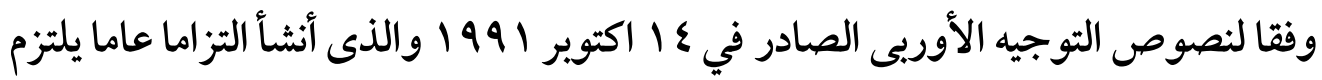

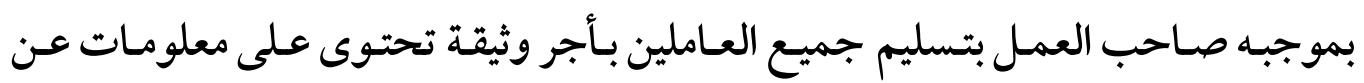

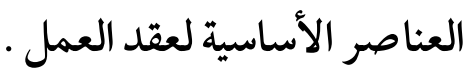
فيجب على صاحب العمل إعطاء العامل وثيقة مكتوبة تحتوى على المعلومـات الواردة

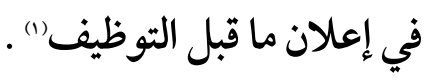

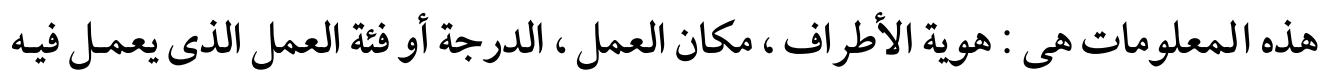

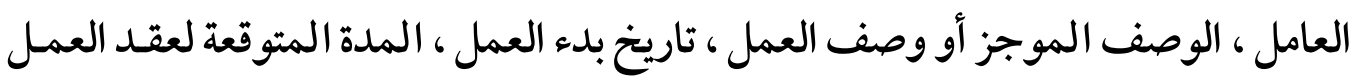

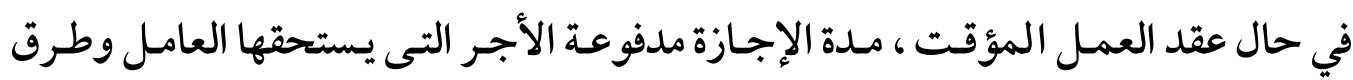

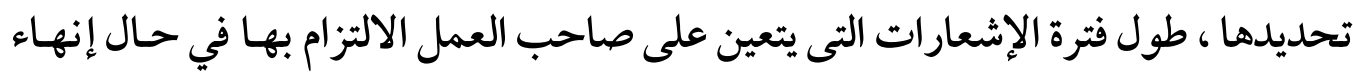

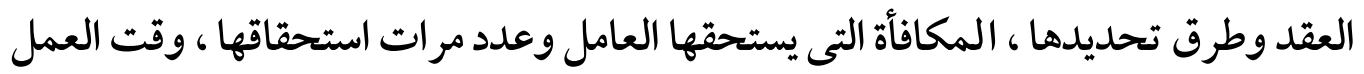

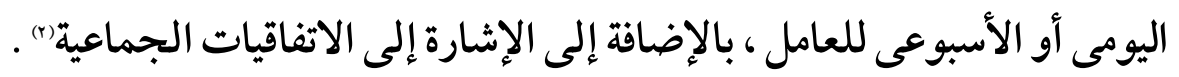

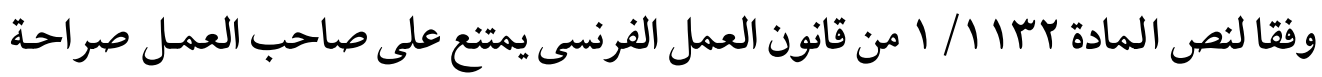

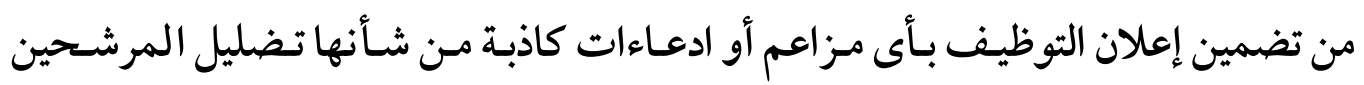

(1) - Martine GOURVES ,op , cit, p. 116 Objet 227

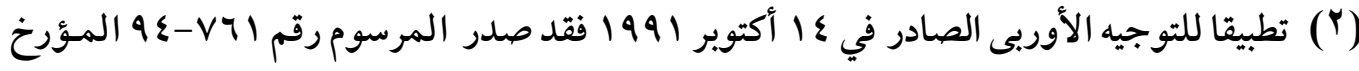

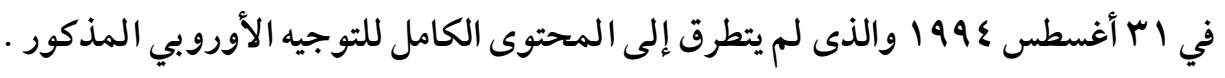




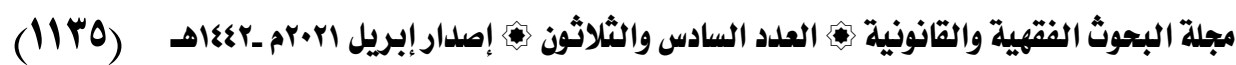

للعمل (1) لاسيما فيما يتعلق بالوظيفة الموجودة بالفعل وبطبيعة ووصف الوفية الوظيفة أو العمل في

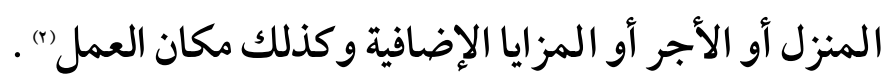

يجـب على صـاحب العمـل إعطاء المرشـح المعلومـات الدقيقـة عـن المنشأة القائمسة بالتوظيف(") وهيكلها القانونى وموقفها المالى (s) .

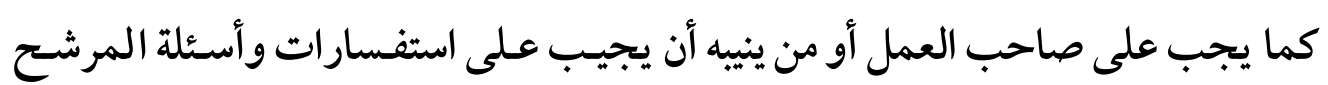
للعمل (0) بخصوص المعلومات التى لا يستطيع الأخير الحصول عليها بنفسه أو لا يستطيع

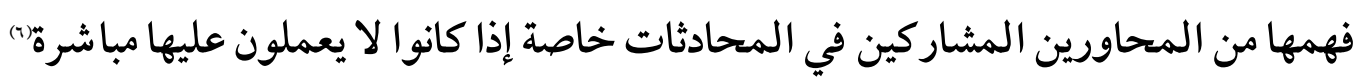

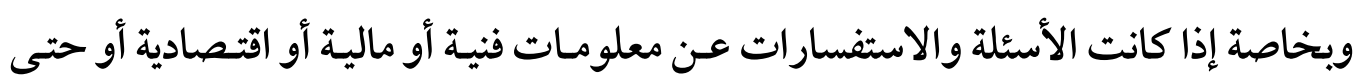
قانونية. بخصوص الوسائل المساعدة في التوظيف والتى سوف يستخدمها صاحب العمل لتقييم

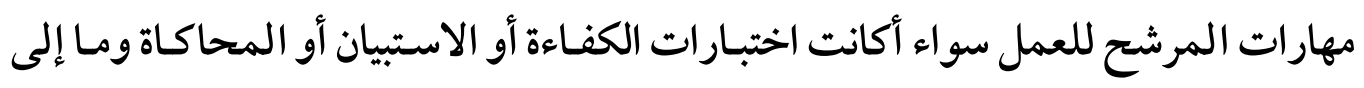

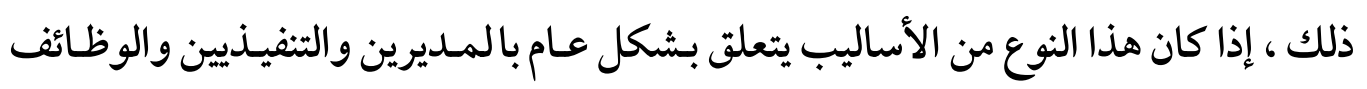

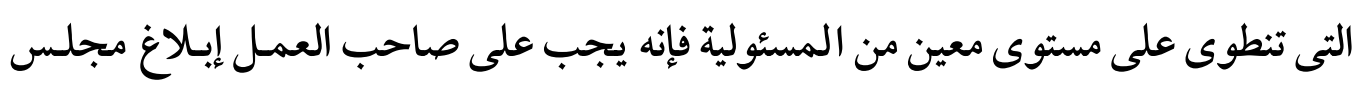

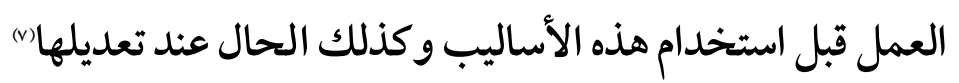

(1) - Martine GOURVES ,op , cit, p. 126 Objet 249

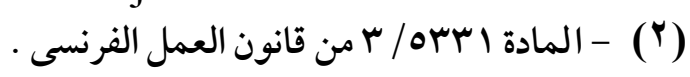

(3)- Léa Amic, op, cit , p.407 Objet 579

(4) - Martine GOURVES ,op , cit, p. 39 Objet 158 - Aurélie Lemettre. Les critères du contrat de travail, Master de droit et pratique des relations de travail, Université Panthéon-Assas Laboratoire de droit social,2010, Objet 302

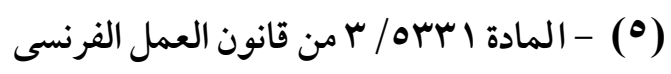

(6)- Martine GOURVES ,op , cit, p. 39 Objet 158

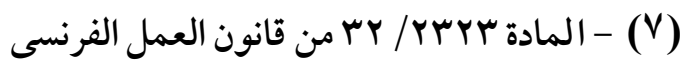


(11rq)

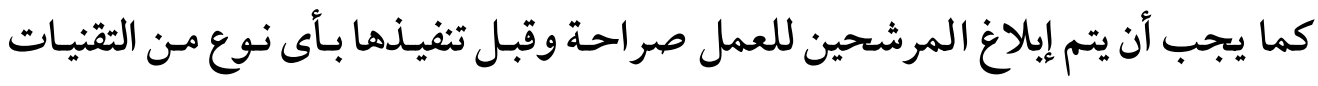

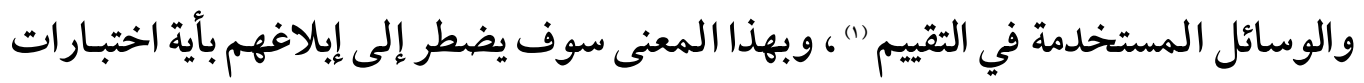

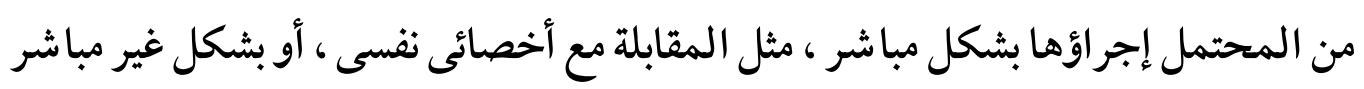

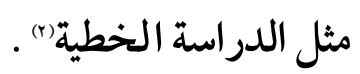
إضافة إلى ذلك فإنه يجب وضع علامة على استبيانات التوظيف تدلل على كون إجابات

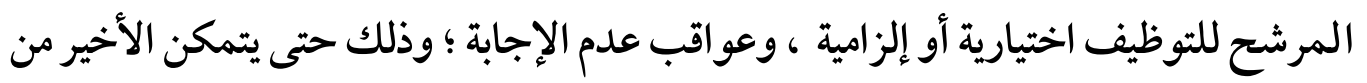

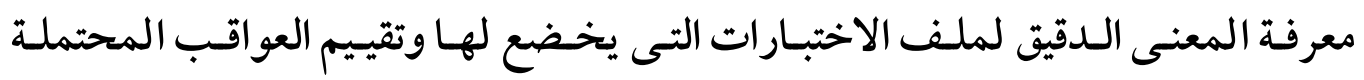

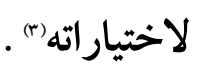

كذلك الحال بخصوص البيانات التى يتم جمعها من المرشح للعمل فإنه يجب أن يكون

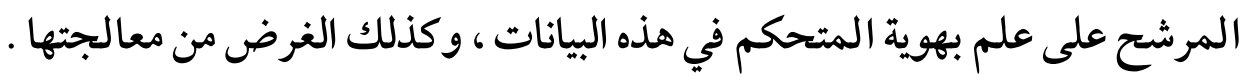

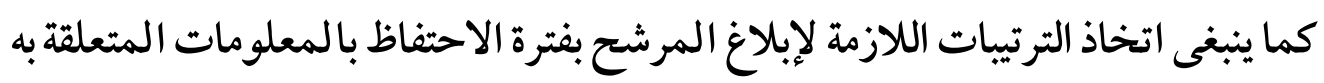

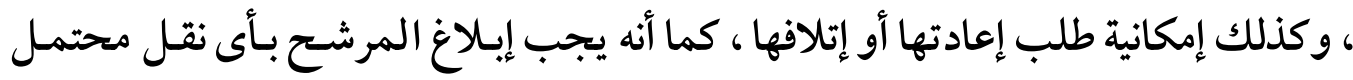

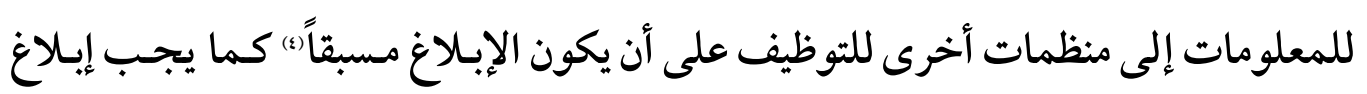

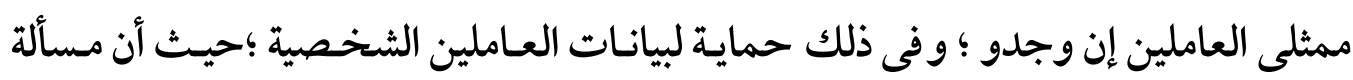
التحاق العامل بالعمل قد تجعله يمتثل لرغبات صـاحب العمـل في المو افقـة على عمليـات معالجة ونقل بياناته الخاصة.).

(1) - لا يمكن جمع أي معلومات تتعلق بالمرشح لوظيفة مـا بواسطة الجهاز الذي لم يوجه انتباهــ Objet 635 Léa Amic, op, cit , p.434

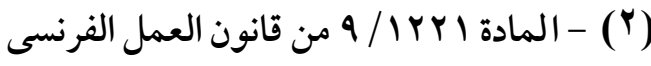

(3)- Martine GOURVES ,op , cit, p. 38-39

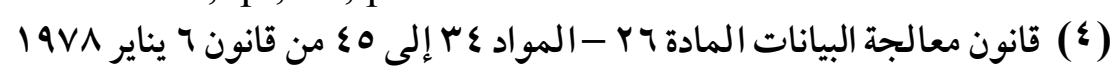

(5)-Panagiota Perraki, La protection de la vie personnelle du salarié en droit comparé et européen : étude comparative des droits français, 


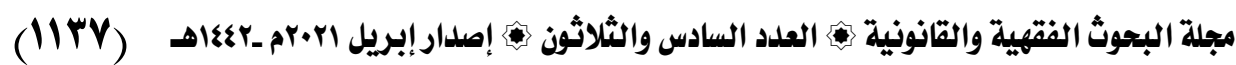

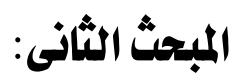

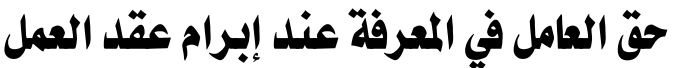

إن القو اعد المطبقة على إبر ام عقد العمل مستمدة مـن القـانون المـدنى ، باعتبـاره القـانون

العام للعقود"(1)، فيتم إبر ام عقد العمل وفقا للشكل الذى يحدده الأطر اف المتعاقدة . ومسع ذلكك فإنـه يجــب الأخــ في الاعتبـار الطبيعـة الخاصـة لعلاقـة العمـل القائمسة بـين متعاقدين: أحدهما طرف قوى ومهيمن على علاقة العمل ( صاحب العمل )، والآخر طرف ضعيف وتابع (العامل) الذى يحتاج إلى حماية تشريعية لا سيما وأنه يوجـد حالة مـن عـدم المساواة وعدم التوازن بين أطر اف عقد العمل خاصة فيما يتعلق بالقدرة في الحصول عـلى له المعلومات ذات الصلة ، وسيستغل صاحب العمل ضعف وجهل العامل الذى سيكون في

وضع لا يسمح له بتقدير الالتزامات التى سيقدمها وبخاصة إذا كان بحاجة إلى العمل (r) .

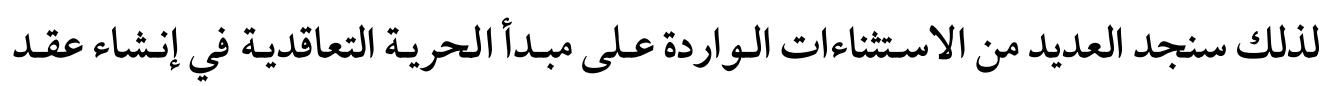
العمل (r) ، حيث نجد أن الموافقة سيكون لها شكل خاص في العديد من أشكال عقد العمل. تنبع خصوصية نظام الموافقة في عقد العمل في القانون الفرنسى مسن صسود الشكلية في التعبير عن الإرادة باستخدام الكتابة كتوجه هدفه حماية العامل (s)، إضافة إلى ضرورة احتواء العقد على المعلومات الإلز امية عند الاقتضاء.

hellénique, britannique et européen, these, universite de Strasbourg 2013.p.274

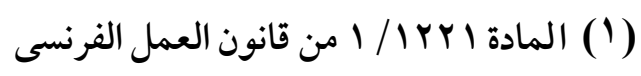

(2) - Martine GOURVES ,op , cit, p. 122 Objet 241

(3)- A.Lepage ,op,cit,p. 142

(4) - Martine GOURVES ,op , cit, p. 115 Objet 225 
(IIrA)

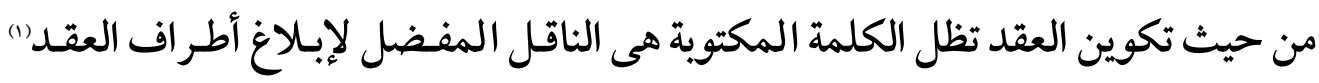

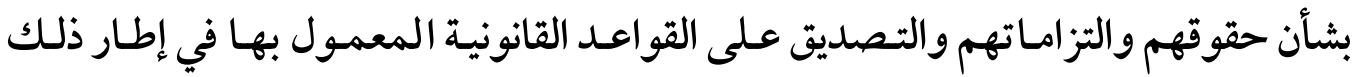

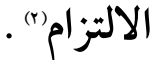

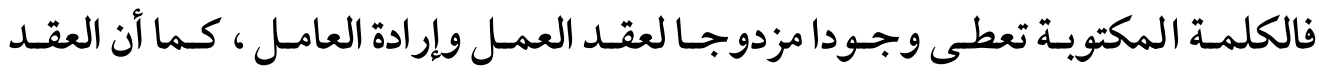
المكتوب يتم استخدامه كأداة قانونية لخدمة الأهداف الجماعية التى حددتها لتها السلطة العامة

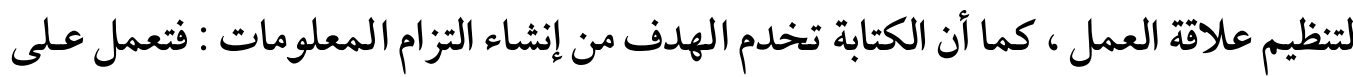

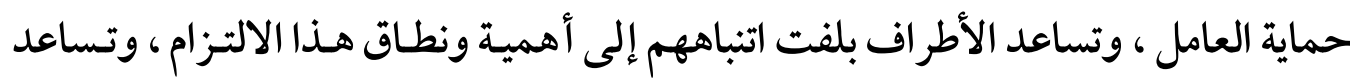
على مراعاة الشروط والالتزامات ونضج التفكير لاتخاذ القرار في أفضل الظروف الممكنة التهنة ،

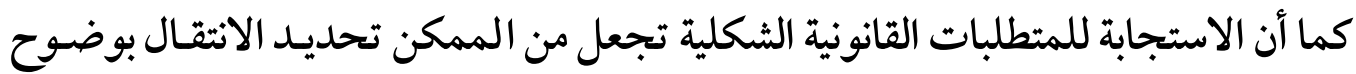
من المشروع إلى الفعل ، من النية إلى المو افقة"(r) .

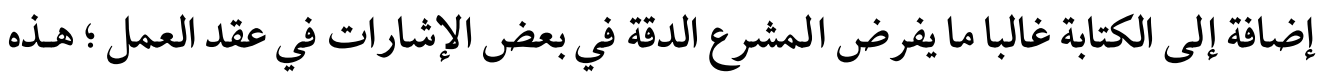

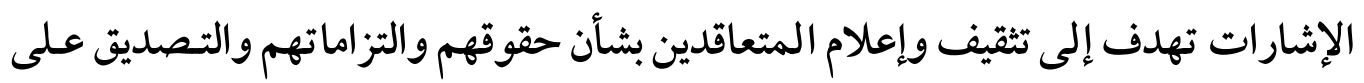

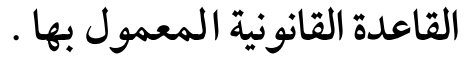
فرض المشرع الصياغة المكتوبة () لإضفاء الطابع الرسمى على اجتماع الإرادات في بعض

(1)- A.Lepage ,op,cit,p. 142

(2)- Martine GOURVES ,op , cit, p. 116 Objet 227

(3)- Martine GOURVES ,op , cit, p. 117 Objet 228

( ) - تنص المادة Yr من قانون العمل المصرى على أنه " يلتزم صـاحب العمل بتحرير عقد العمل

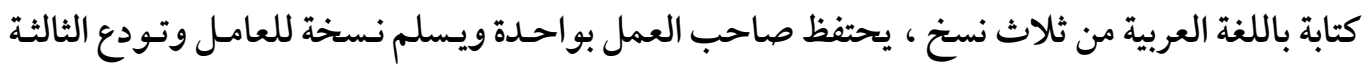
مكتب التأمينات الاجتماعية المختص. ـ ويجب أن يتضمن العقد علي الأخص البيانات التالية: اسم صاحب العمل وعنوان صاحب العمل.

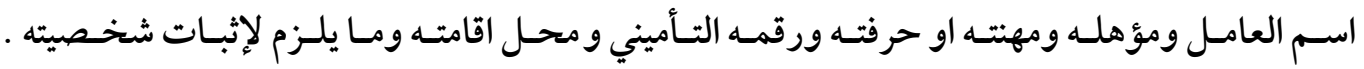

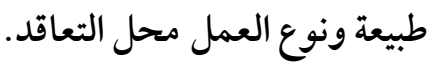




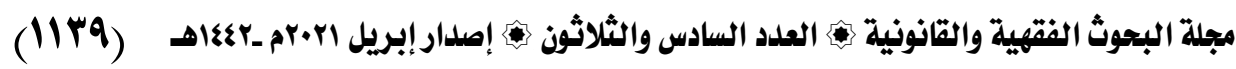
العقود المحددة (1) ( العقد محدد المدة - العقد المؤقت - عقد العمل بدوام جزئى - عقـد

$$
\text { التدرج المهنى - العقود المبرمة مع أصحاب الأعمال ) }
$$

بالنسبة لعقد العمل غير محدد المدة فلا يجب مراعاة أى إجراء شكلى مـالم يتم الاتفـاق على خلاف ذلك ؛ لذلك الكتابة غير مطلوبة ، ومـع ذلك يـوصى بـشدة بـصياغة عقـد العمل لمنع أى نزاع يتعلق بتنفيذ العقد ؛ لذلك تنص الاتفاقيات الجماعية على الالتزام بكتابة العقد غير محدد المدة وإضفاء الطابع الرسمى عـلى قبـول الطـرفين • فبإذا تمـت كتابـة العقد غير محدد المدة فيجب كتابته باللغة الفرنسية(r) .

فإذا كانت الأرضية المشتر كة أن القانون لا يتطلب صياغة عقد مكتوب ، فإن الحقيقة تبقى أن العديد من العناصر القانونية في علاقات العمل تعمل لصالح إنشاء كتابـة : فعلى سـبيل المثال يلزم المشرع صاحب العمل إعطاء العامل وثيقـة مكتوبـة تحتوى على المعلومـات الأجر المتفق عليه وطريقة موعد أدائه و كذلك سائر المزايا النقدية والعينية المتفق عليها ، وإذا لم يوجـد عقد مكتوب للعمل وحده إثبات حقوقه بكافة طرق الإثبات.

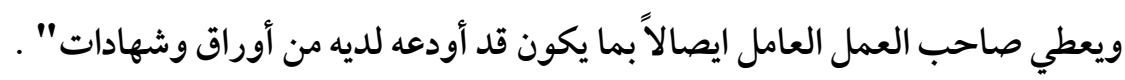

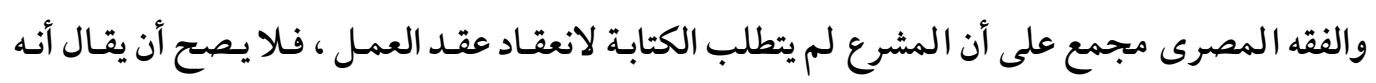
عقد شكلى ، بل هو عقد رضائى ، حيث إن الكتابة ليست ركنا لازما لإنعقاد عقد العمل .

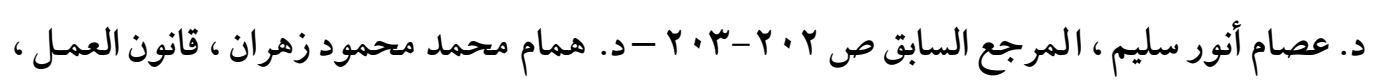

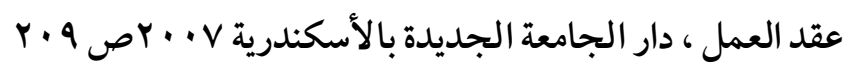

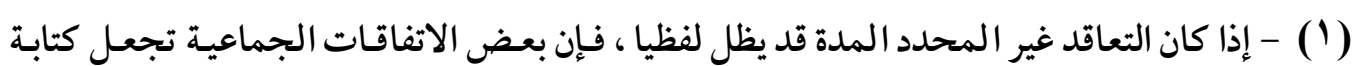
عقد العمل إلزامية.

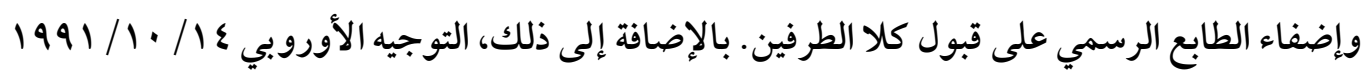

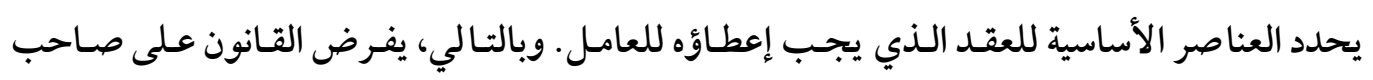
العمل إعطاء العامل وثيقة مكتوبة تحتوي على المعلومات الواردة في بيان ما قبل الموافقة.

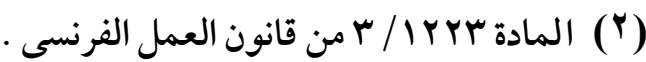


(11క*)

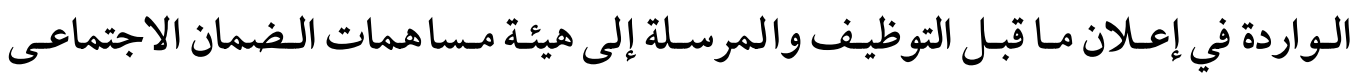
.(')(URSSA)

بالنسبة لعقد العمل محدد المدة فإن اللجوء إلى الكتابة إلزاميا ، وفى حـال غياب الكتابة

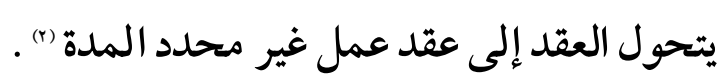

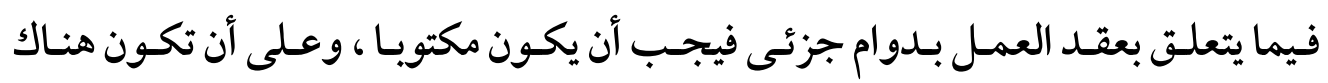

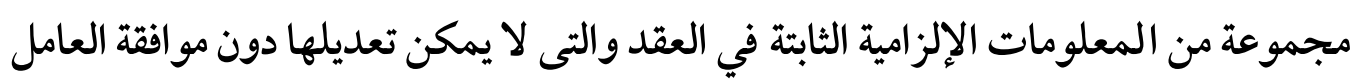

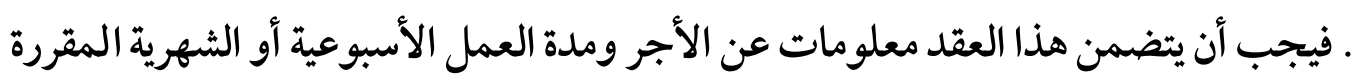
، وتوزيع العمل بين أيام الأسبوع أو أسابيع الشهر (") .

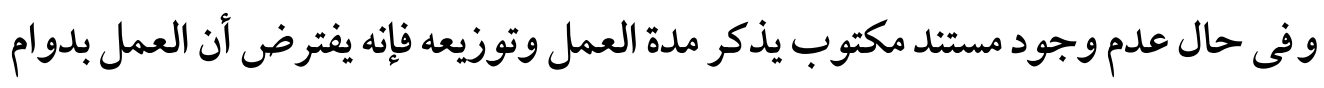

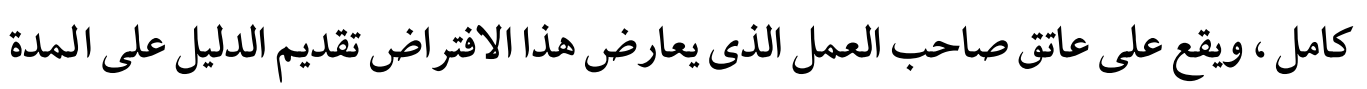
الأسبوعية أو الثهرية المحددة والمتفق عليهاء) . بخصوص توزيع ساعات العمل فإن محكمة النقض الفرنسية(م)ترى أنه غير مطلوب ذكرها

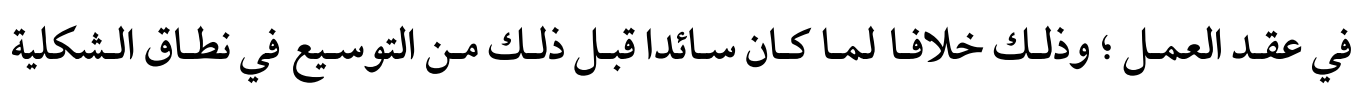

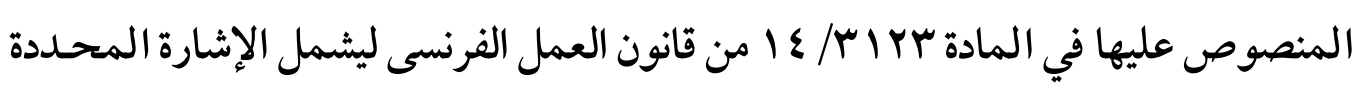

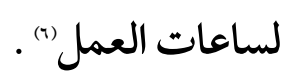

(1)- Martine GOURVES ,op , cit, p. 116 Objet 227

$$
\text { (Y) }
$$

(4)-A.Lepage ,op,cit,p.143-_Soc., 9 avril 2008, Bull. 2008, V, no 84, pourvoi no 06-41.596

(5)- Cass. soc., 14 décembre 2016, $\mathrm{n}^{\circ}$ 15-16.131, Publié au bulletin, Décision attaquée : Cour d'appel de Dijon, du 05 février 2015

(6)- A.Lepage ,op,cit,p.143 


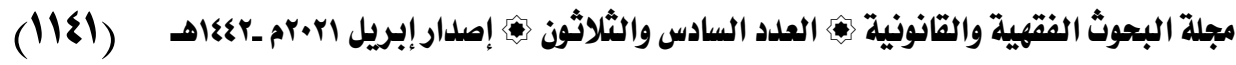
بالنسبة للعقد العمل المؤقت فإن الكتابة إلزامية وفق لنص المـادة ا هY I / 1 ا مـن قانون العمل الفرنسى ، وفى حال استمرار الشركة في توظيف العامل بعـد انتهاء مهمتـه دون إبـرام عقد العمل فإن هذا العامل يعتبر مرتبطلا بالشر كة المـستخدمة له بموجـب عقـد عمل غير

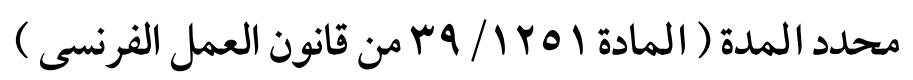
العقوبة لعلدم كثابة عقد العمل: رأينا فيما سبت أن المششرع الفرنسى يطلب في كثير مـن الأحيـان ضرورة القيام ببعض الإجر اءات الشكلية ومنها الكتابة لبعض عقود العمل ، وهذا يعنى أن هـذا الإجـر اء جـوهرى عند ولادة عقود العمل المعنية ، وتعد مظهر ا من مظاهر توافق إر ادات أطر افه' (1) . فإذا كان عقد العمل مثله مثل جميع العقود يقوم على الموافقة المستنيرة الحرة من أطر افه

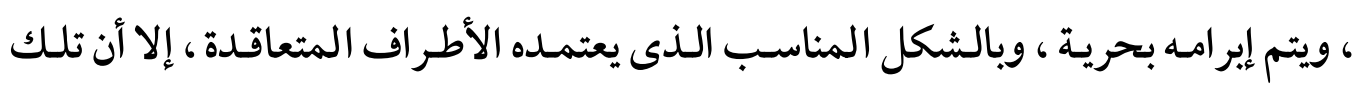
الحرية التعاقدية تعنى حرية الأطر اف في الدخول في العقد وذلك دون شرط الشكل وتحديد

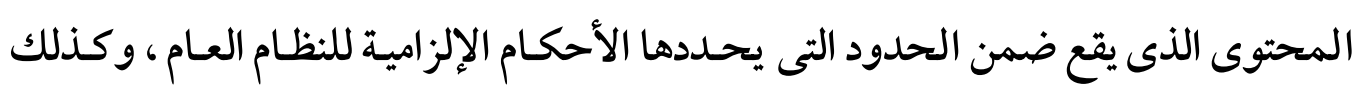
القيود الواردة في قانون العمل "(r) . في الواقع تتنوع النصوص التى تنطلب الامتثال للإجر اءات الشكلية التى يتعين إكمالها من الأطر اف التى توقع عقود عمل معينه كما سبق أن أوضحنا ، سواء أكان الإجر اء المطلوب هو

حيث إن نقص المعلومات الخاصـة بالعامـل عن سـاعات عملـه يمكـن أن يكـون خطير العواقـب على صاحب العمل بإعادة تصنيف عقد العمل إلى عقد عمل بدوام جزئى . .Soc., 9 avril 2008, Bull. 2008, V, no 84, pourvoi no 06-41.596 (1)- Martine GOURVES ,op , cit, p. 118 Objet 231.

(2)-SANGARE YACOUBA, LES SANCTIONS EN DROIT DU TRAVAIL , THESE , UNIVERSITE DE CERGY-PONTOISE, 2012 ,p.42 
(llsr)

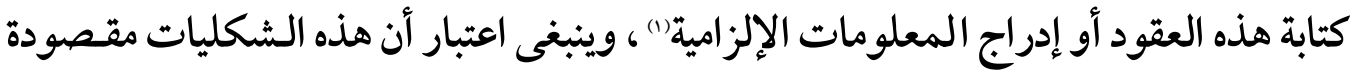
للتحقق من التزام عقد العمل بالافتراضات والثروط المنصوص عليها من قبل المشرع) (") .

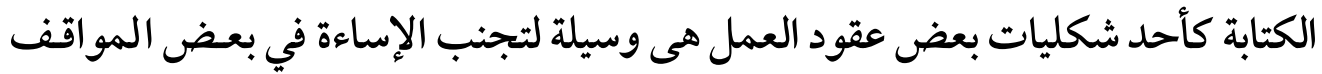
من جانب أحد أطر اف عقد العمل ، في الواقع يمكـن أن نجـــ أن أحـد أطر اف عقد العمل

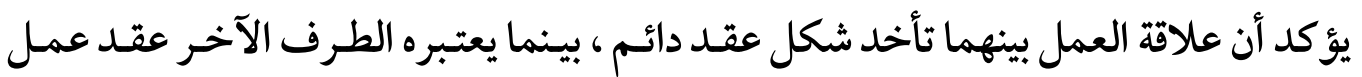
محدد المدة). (1).

لذلك تبدو الكتابة كدعم لهذه العلاقة ، وضرورية عندما نواجه عقدعمل محـدد المـدة ، وذلك بخلاف عقد العمل غير محدد المدة) . وفى حال عدم الامتثال لشرط الكتابة سيتم إعادة تصنيف العقد من عقد عمل محدد المدة إلى عقد عمل غير محدد المدةثم) . وهذا الحل في عدم الامتثال للشكلية المطلوبة لعقد العمل محدد المدة ولغيره من العقود المطلوب كتابتها (1) يبدو كحل أفضل ينص عليه القانون ، وبالتالى فيإن إعادة التصنيف دون تطبيق قواعد بطلان عقد العمل هدفه استعادة العقد الحقيقى ودون التوقف عند الاسم الذى ألى

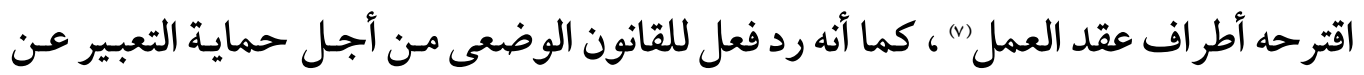

(1)- Martine GOURVES ,op , cit, p. 119 Objet 333

(2)- Annee Severine DHENNIN, la nullite du contrat de travail, THESE, UNIVERSITE DE DE LILLE2, 2001 .p.118

(3)- Ibid,p.116

(4) - Ibid

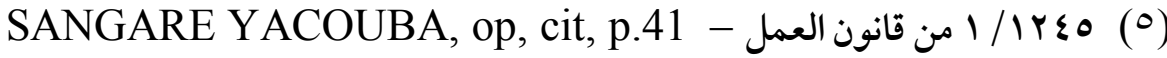
(T) يتم إعادة تصنيف عقد التلمذة الصناعية كعقد عمل غير محدد المدة ونتيجة لذلك يتلقى المتدرج أجر يحسب على أساس الحد الأدنى للأجور الخاصة بمهنته .

(7)- Annee Severine DHENNIN,op,cit ,p. 123 


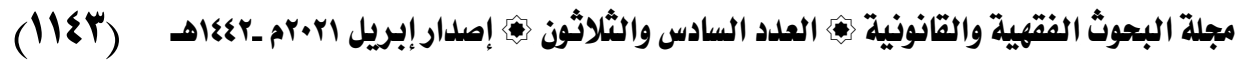

مو افقة العامل ، وتعبير اعـن الاهـتمام الواضـح بتـأمين علاقـة العمل التعاقديـة") حيـث تعتبر شكلية عقد العمل موضـوعة لحمايـة العامـل ؛ لـذلك فـإن عقوبـة الإبقـاء على العقـد بإعـادة تصنيفه إلى عقد دائم توفر حماية خاصة للعامل فقط ، الذى يمكنه وحـده الاحتجـاج بإعـادة تصنيف العقد ، ولا يمكن لصاحب العمل المطالبة بإعادة التصنيف(r) ، كما أن إعادة التصنيف

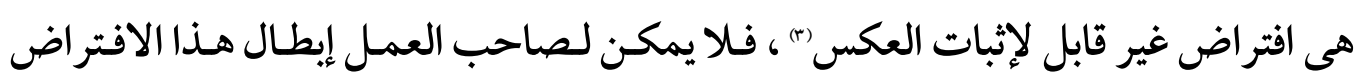
القانونى من خلال تقديم دليل على وجود عقد شفهى مبرم لفترة محددة (s).

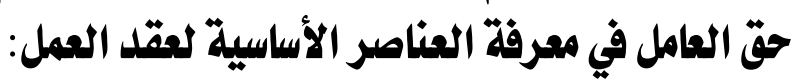

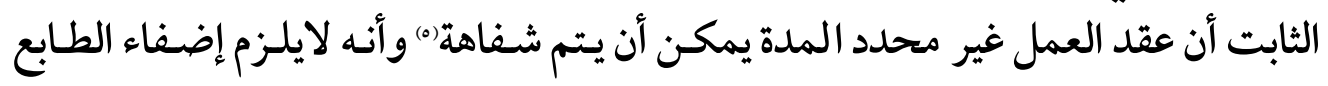
الرسمى عليه ؛ لذلك من الممكن أن ينفذ العامل عقدا لا يعرف نطاقه الحقيقى ()، و وفى مثل

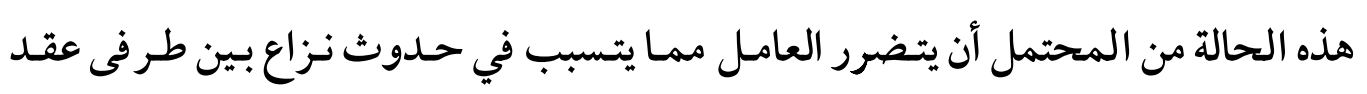

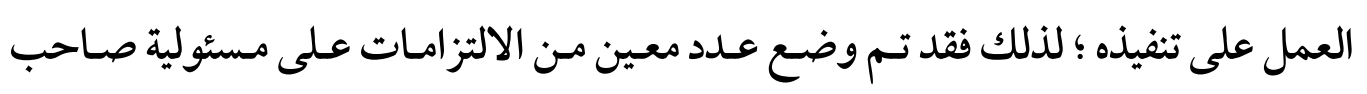
العمل بحيث يوفر للعامل مجموعة كاملة من المعلومات .

(1)- Martine GOURVES ,op , cit, p. 119 Objet 233

\section{SANGARE YACOUBA,op,}

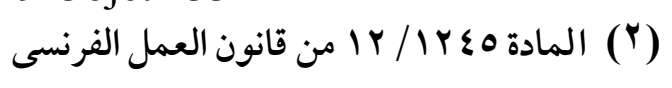

SAN 1987, Bull. 1987, V, no 481, pourvoi no 85-45.258- Soc., 4 décembre 2002, Bull. 2002, V, no 367, pourvoi no $00-43.750$; Soc., 7 avril 2004, Bull. 2004, V, no 106, pourvoi no 02-40.231

(3)- Cass. soc. 21 mai 1996, D. 1996 p. 565, obs. Yves CHAUVY

(4)- SANGARE YACOUBA,op, cit, p.42-43- Annee Severine DHENNIN,op, cit ,p. 116-117

(5) -Cass. soc., 14 mars 1995, n 91-43.788, Inédit

$$
\text { (1) لذلك تنص معظم الاتفاقيات الجماعية على الالتزام بكتابة عقد العمل غير محدد المدة }
$$


(11)

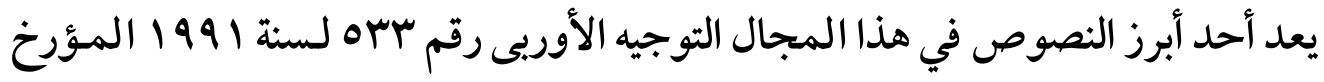

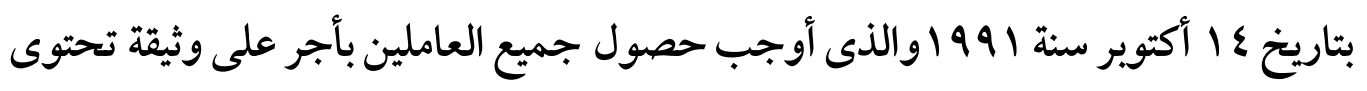
على العناصر الأساسية لعقد العمل (1) .

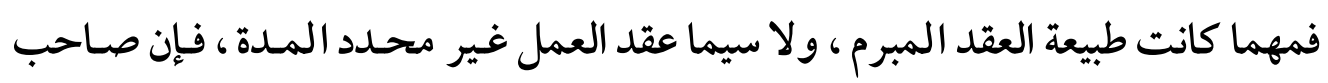

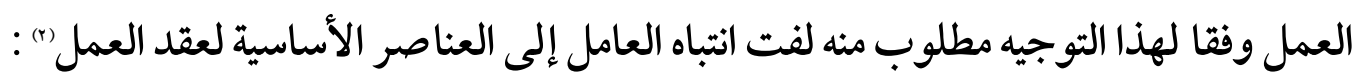
مثل طبيعة العمل والأجر ومكـان العمل وسـاعات العمل والاتفاقيات الجماعيـة السارية وغيرها من العناصر الأساسية لعقد العمل.

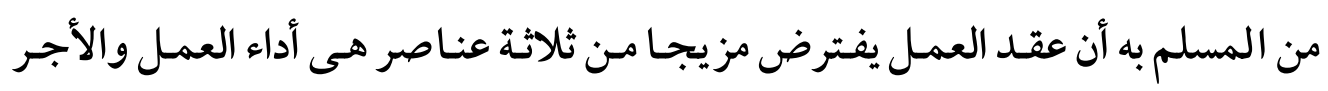
ورابطة التبعية () ، وهذه العناصر تسمى العناصر التعاقدية والتى إذا غـاب أحسدها فلـن نكسون

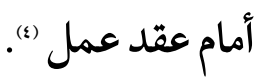

فالأجر هو موضسوع الالتزام الرئيسى لصاحب العمل ، وهو مقابل للعمل الذى يؤديـ

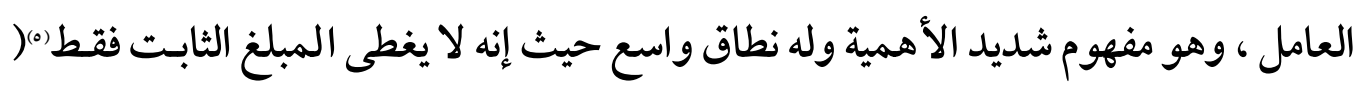

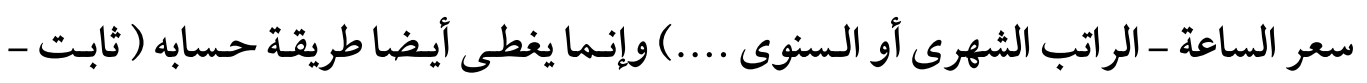

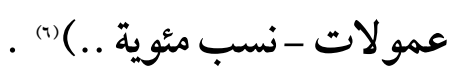

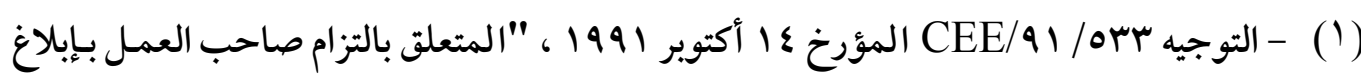
العامل بالشروط المنطبقة على العقد أو على علاقة العمل " المؤرها

(2) - A.Lepage, op,cit,p.144

(3) - Jean PÉLISSIER. La détermination des éléments du contrat de travail, le Droit Ouvrier, MARS 2005, p.92-

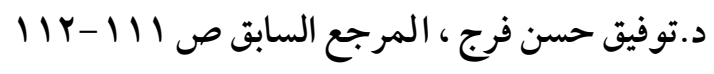

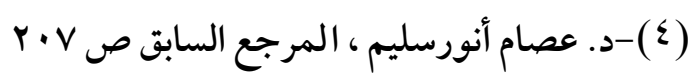

(5)- Martine GOURVES ,op , cit, p. 86 Objet 175

(6)-Cass.Soc. 30/05/2000, Liais. Soc. du 22/06/2000 jp n ${ }^{\circ} 680$ et du $20 / 07 / 2000 \mathrm{jp} \mathrm{n}^{\circ} 683$ 


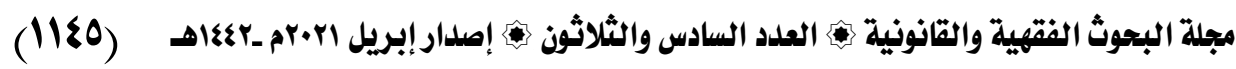

كذلك الحال فإن طبيعة الوظيفة وأداء العمل هو موضوع الالتزام الرئيسى للعامـل ، حيـث يتم تعيينه وفق تدريبه الوظيفى وخبر اته لأداء وظيفة معينة تقابل مؤهلاته .

بالتالى فإن الأجر و العمل همـا العنصـر ان الأساسـيان المميـزان للعمـل (1)، والمفـترض أن يكون العامل قد وافق عليهما وقت تكوين العقد سو اء أكان عقداً مكتوباً أم لا(r) .

أما الفئة الثانية من عناصر عقد العمل : مثل مكان العمل ومدته وتوزيع العمل والاتفاقيات الجماعية فهى مرتبطة بالمجال التعاقدى إذا كان هناك بند صريح بذلك

وسوف نستعرض تباعا هذه العناصر على النحو التالى :

المدة العمل

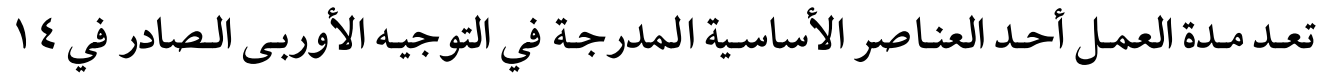
أكتوبر سنة | 199 ، وبصرف النظر عن هذا التوجيه وبـصرف النظر عن كونـه ملزمـا أم أنه مجرد تصوية ، فإن الشائع أن مدة العمل ليست جزءًا من جوهر العقد إلا مـن خحلال ذكرهـا في العقد هو الذى يجعلها عنصرا أساسيا في العقد "(r) . هذا وتعد مدة العقد عنصرا ضروريا في عقـد العمل محـدد المـدة (s) ، و الـذى يجـبـ أن يحدد فيه مدة العقد وتاريخ التعيين وتاريخ انتهاء العقد .

أما بخصوص ساعات العمل فإنها لا تعتبر ضرورية للعقد ، وفى حال عدم وجود شرط

(1)- Henrik de Brier, - La mobilité du salarié, Thèse, Université d'Avignon, 2015 . p.82 - Cass. soc., 3 mars 1998, $\mathrm{n}^{\circ}$ 95-43274, Herzberg, note G. COUTURIER, La rémunération, élément essentiel du contrat de travail, Dr. soc. 1998, p. 523

(2) - Martine GOURVES ,op , cit, p. 86 Objet 175

(3)- Serge Diena Diakiese: Modification du contrat de travail en vertu de la loi congolaise,Université protestante au Congo, L'année académique 2004/2005,p.31 rAV د همام محمد محمود زهران ، المرجع السابق ص'

(4)- Martine GOURVES ,op , cit, p. 87 Objet 176 
$(11 \leqslant 7)$

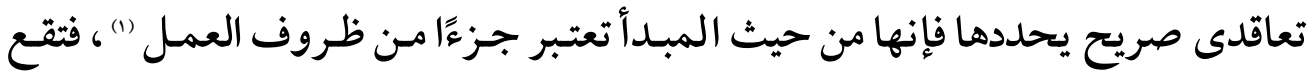

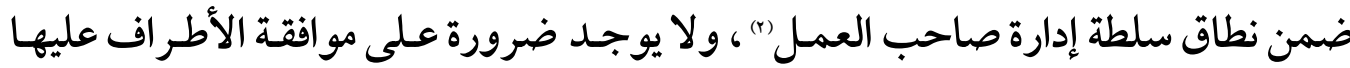
أثناء تكوين العقد ، ما لم يعرب طر فى عقد العمل عن رغبتهما في ذكرها على وجه التحديد

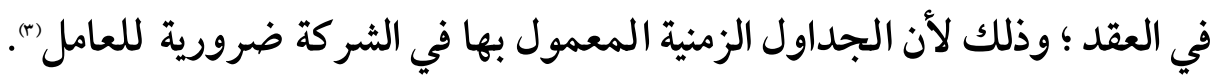

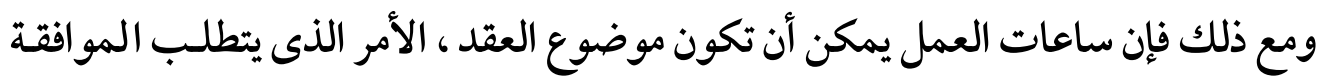

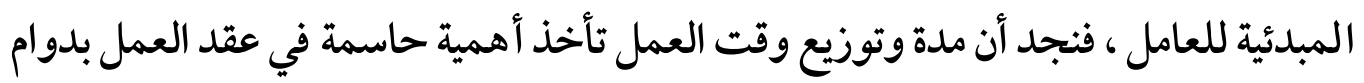

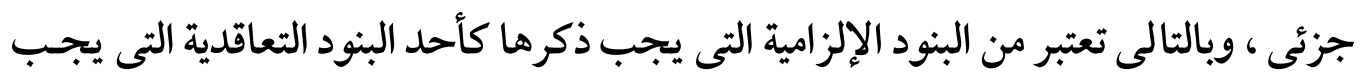

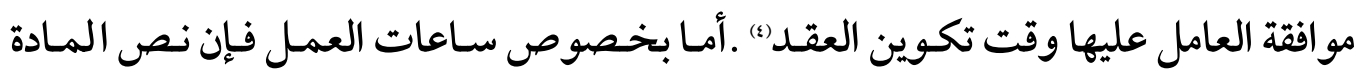

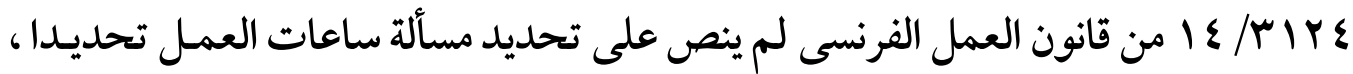
ومع ذلك فإن محكمة النقض الفرنسية كانت توسع من نطاق الشكلية المنصوص عليها في المادة سالفة الذكر ليشمل الإشارة لساعات العمل .

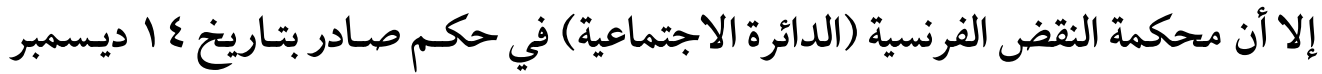

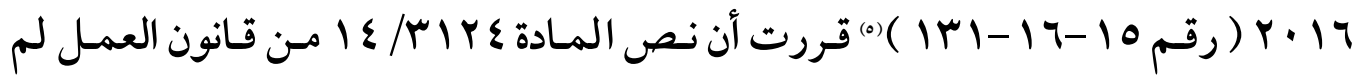

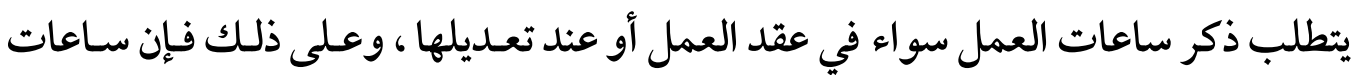

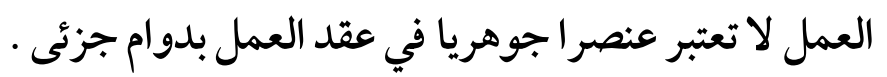

(1)- Ibid ,Objet 177- Cass.Soc. 22/02/2000, Liais.Soc. du 06/03/2000, jp n664. Cass.Soc. 02/02/1999, Dr. Soc. 1999 p 419

$$
\text { الجداول الجماعية هي أيضا موضوع المعلومات عن طريق النشر. }
$$

Martine GOURVES ,op , cit, p. 88 Objet 177.

(3) - Ibid

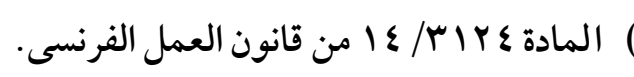

(5)- Cass. soc.,14 décembre 2016, $\mathrm{n}^{\circ}$ 15-16.131, Publié au bulletin, Décision attaquée : Cour d'appel de Dijon, du 05 février 2015 


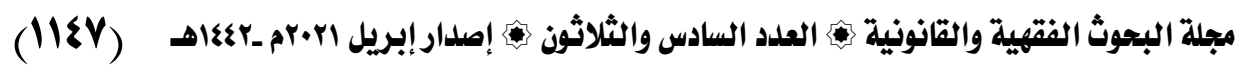

وبرغم الاتجاه الجديد لمحكمة النقض إلا أن الممارسة العملية تستحسن ذكر سـاعات العمل ضمن عقد العمل بدوام جزئى . r. مكاز العمل

إن مكان أداء العمل ليس في حد ذاته عنصر ا أساسيا في عقد العمل وإنما يأتى تحت سلطة صاحب العمل في تنظيم العمل (1) ما لم تتجه النية المشتر كة للمتعاقدين إلى غير ذلك((). في حال عدم وجود بند تعاقدى بشأن مكان العمل فإن مكان العمل يتم تفسيره على أساس

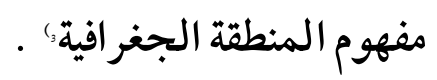

فإذا كان مكان العمل محهـدداً بموجـب بنـد تعاقـدى أو بموجـب اتفـاق جمـاعى فـإن هـذا المكان يصبح عنصراً تعاقـدياً يتجـاوز السلطة التنظيميـة لصحاحب العمل ، ليصبح عنصراً

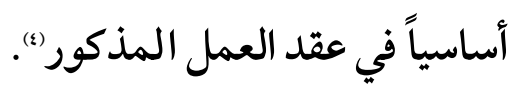

يعد ذكر مكان العمل في عقد العمل ذو طبيعة إعلامية(م) للفت انتباه العامل (") ، مـا لم يكن هناك بند واضح ودقيق بأن العامل سـوف يؤدى عمله حصريا في هـذا المكـان، مـع موافقة العامل على هذا البند الحصرى أثناء تكوين العقد (v) ، في هذه الحالة فإن صاحب العمل لن يستطع تغيير هذا الموقع حتى ولو كان التغيير لمكان داخل المنطقة الجغر افية للعمل (م).

(1)-Henrik de Brier,op,cit,p.78 Objet 113 - Serge Diena Diakiese,op,cit,p.28.

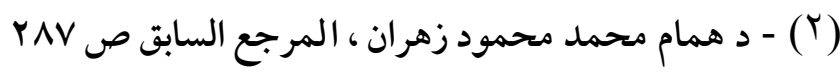

(3)- Martine GOURVES ,op , cit, p. 84 - Cass. soc. 20/10/98 Boghossien c Sté Jelt CM, Dr.Soc. 1998 p 1046 obs. Ph.Waquet, RJS 1/99 n8. V.infra Titre II, Chapitre

(4)- Henrik de Brier,op,cit,p.78 Objet 113

(5)- Jean PÉLISSIER,op,cit,p.94

(6)- Henrik de Brier,op,cit,p.90 Objet 129

(7)- Martine GOURVES ,op , cit, p. 84 Objet 176

(8)- Jean PÉLISSIER,op,cit,p.95 
$(11 \leqslant \wedge)$

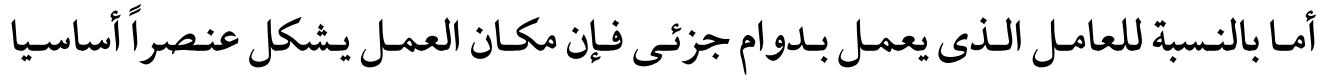

$$
\text { وجوهرياً في عقد العمل (1). }
$$

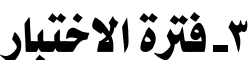

تعد فترة الاختبار من ضمن البنود التعاقدية التى لا تفترض () ، وإنما تنشأ من اتفاق أطر اف

عقد العمل (ه) ، حيث يجب على العامـل التعبير عن إرادته بالموافقة على الخضوع لفترة الاختبار وذلك ببند عقدى يقرر ذلك") ، وفى حال عدم وجود هذا البند التعاقدى فـلا يمكن

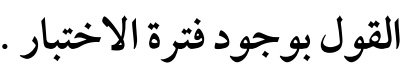

فلكى تكون هناك فترة اختبار فإنه يجب أن يتم النص عليها صر احة في خطاب الارتباط أو

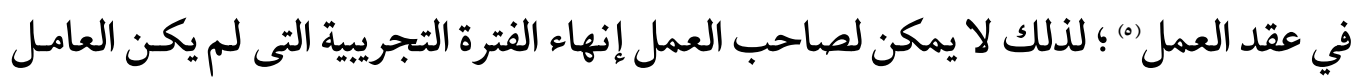

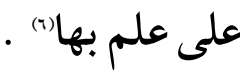

ويعد هذا البند أحد البنود التى لا تلقى ترحابا من قبل العامل ؛ وذلك لأنه يتخوف من إساءة استخدام صاحب العمل سلطته في الإنهاءء" .

(1) - Serge Diena Diakiese,op,cit,p.29

(2)- Cass. soc., 23 novembre 1999, n 97-43.022, Bull. civ. V, n 448

$$
\text { I } 19 V \text { (T) }
$$

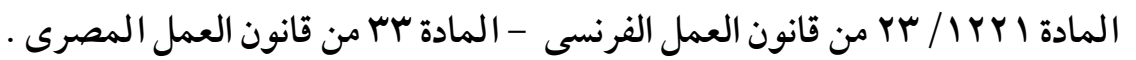

(5)- Martine GOURVES ,op , cit, p. 67et 93

(6)- Cass. soc., 20 novembre 2007, $\mathrm{n}^{\circ}$ 06-41.212, Bull. civ. V, n 194

(7)- Martine GOURVES ,op , cit, p. 94 Objet 189 


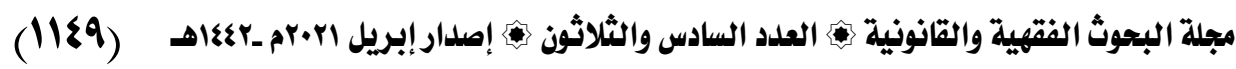
الغرض من فترة الاختبار هو تقييم صاحب العمل للقدرات الفعلية للعامل (1) ؛ ليتين كفاءته وصلاحيته للعمل وحسن تعاونه مع غيره مـن العـمال(r) ، كـما أن العامـل يستطيع أن يقيس عبء الوظيفة التى سيشغلها ومدى ملاءمتها له (r) . وتعد فترة الاختبار مستقلة تماما عن التفاوض والوعد بالتعاقـد ، بـل وحتى عقــ العمـل ، حيث يحق لأى طرف من أطراف عقد العمل الانسحاب منها بحرية كاملة في أى وقت دون

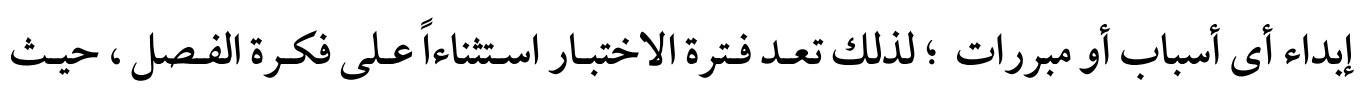
يستفيد منها وبشدة صاحب العمل بشكل رئيسى ، كما أنها تعد تنازل من العامل عن حقوقه إذا تم فصله ؛ لذلك من المهم التحقق من أن العامل قد وافق على هذا التنازل(s) . وحيث إن التنازل لا يفتر ؛ لذا فبإن فـترة الاختبـار لا تفـترض كما سـبق القـول ، وإنما

$$
\text { يجب أن تنشأ عن اتفاق الطرفين · }
$$

كذلك فإن تجديد أو تمديد الاختبار لا يفترض وإنما لابد من أن ينشأ من القبول الصريح من قبل العامل وعلى أن يكون هذا القبول للتجديد قبل انتهاءفترة الاختبار (ه).

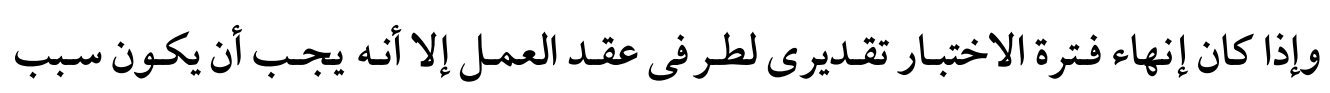
الإنهاء موجوداً شرعياً، فلابد أن يعتمد صاحب العمل على أن الإنهاء بسبب عنصر متعلق بأداء عمل العامل المتعاقد وليس بسبب عنصر غريب عن أداء العمل (1) .

(1)-CA Paris, 23 nov. 1990, D. 1992, Jurisp. p. 101, note G. PIGNARRE. L'article L. 1221-20 C. trav. Reprend - Soc. 19 févr. 1997, Bull. civ. V, nº 69 ; Soc. 27 janv. 1997, Bull. civ. n 33

$$
\text { r.r. (r) }
$$

(3)- Léa Amic, op, cit , p.443 Objet 656

(4)- Martine GOURVES ,op , cit, p. 92 Objet 187

(5)- Ibid, p. 94

(6)- Léa Amic, op, cit , p.444 Objet 658- Soc. 18 juin 1996, JCP éd. G.

1996, II, 22739, note C. PUIGELIER 
(110.)

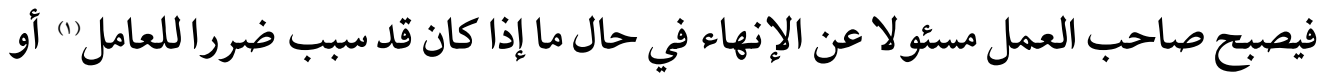
أنه خالف الغرض من الاختبار أو أن الإنهاء كـان سريعا ولم يستطع صـاحب الإنهاء العمل تقييم

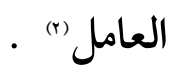

وقد حدد المشرع مدد قصوى لفـترة الاختبار ، بـما في ذلك التجديد ، وذلك وفقـا لفئة

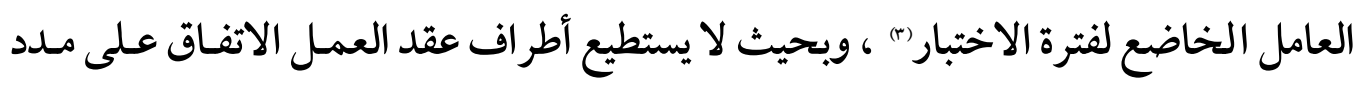

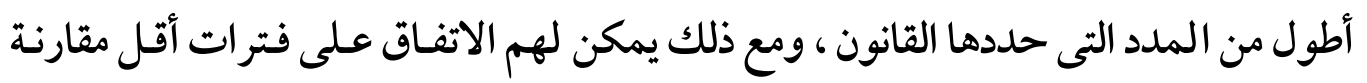
بتلك المنصوص عليها من قبل المشرع (s) .

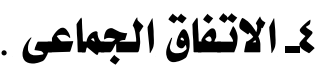
ابتدع قانون العمل تقنيناته القانونية الخاصة للتعامل مع خصوصية العلاقات التى يحكمها ، حيث إن عدم المساواة بين العامل وصاحب العمل هى العلاقة الأساسية التى تشكل بـلايلا

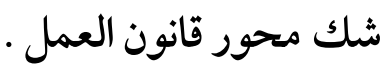
وحيث إن قانون العمل يسعى إلى تعويض العامل عن التبعية القانونية التى تمنعه - بصفته

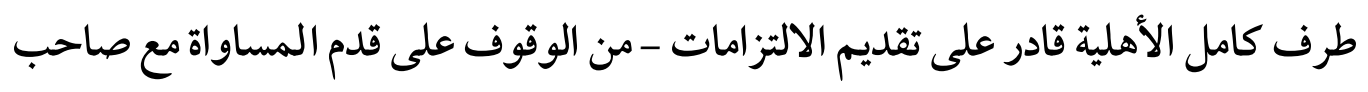
العمل صاحب القوة ؛ حث إن العامل لا يعتبر متعاقـدا عاديـا فقط وقـت التعاقد وإنـما هـ

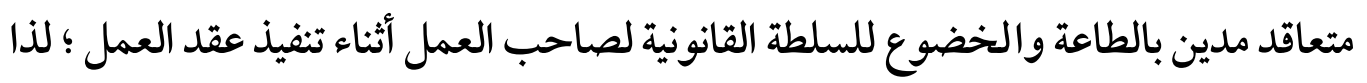
كان من الضرورى موازنة هذه القوة ، وذلك بالوسائل القانونية ، والتى منها وسائل جماعية

(1)- Cass. soc., 5 mai 2004, ${ }^{\circ}$ 02-41.224, Bull. civ. V, $\mathrm{n}^{\circ} 123$

(2)- Cass. soc., 15 novembre $2005 \mathrm{n}^{\circ}$ 03-47.546, Bull. civ. 2005, V, $\mathrm{n}^{\circ}$ 321- CA Paris, 11 déc. 2008, n 07-2548 (le salarié s'était présenté à 9 heures pour prendre son poste et s'était vu.

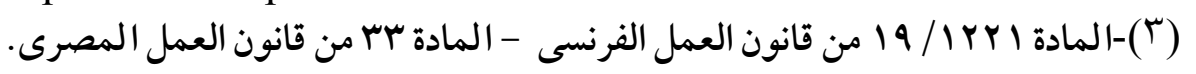

(4)- Martine GOURVES ,op , cit, p. 94 


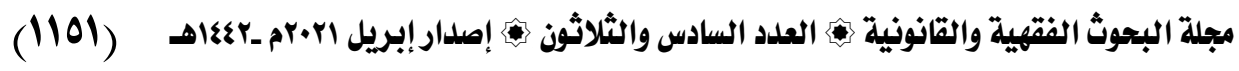
حيث تم استبدال العامـل كمدحـاور لـصاحب العمـل بالمفاوضـة الجماعيـة التى ينتج عنها الاتفاق الجماعى الذى يحل محل العقد الفردى كمصدر للحقوق والالتزامات") . تكمن أصالة هذا العمل الجماعى في أساسه المزدوج ، حيث مبـأ الحريـة التعاقديـة مـن

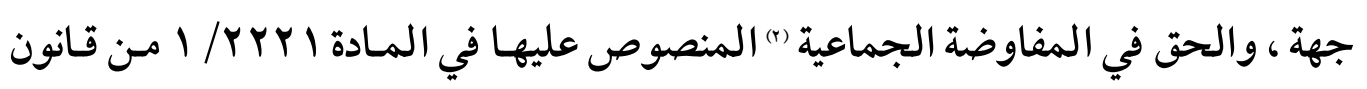
العمل الفرنسى. وحيث إن الاتفاق الجماعى هو أحد القواعد التى تحكـم العلاقـة التى تربط بـين العامل

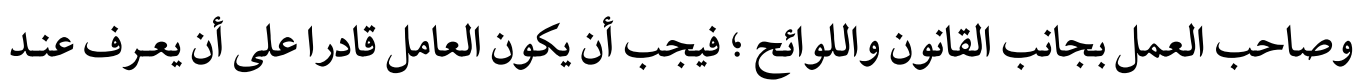
التزاماته فيما يتعلق بالاتفاق الجماعى ؛ لذلك يجب على صـاحب العمل أن يعطى العامل وقت التعيين معلومات حول النصوص التقليدية المعمـول بها في مؤسسته ، ومـن ضـمنها تقديم قائمة بنصوص الاتفاقيات الجماعية المعمول بها . فيجب إبلاغ العامل بوجود اتفاق جماعى ، كما يجب وضعه في مكان يسمح له بالمعرفة : وهذا يعنى أن العامل يتمتع بحقه في الحصول على معلومات حول وضعه الجماعى وفقـا

(1) - لا شك أن مركز كل عامل من العمال فرادى أضعف في القوة الاقتصادية من مركز صـاحب العمل

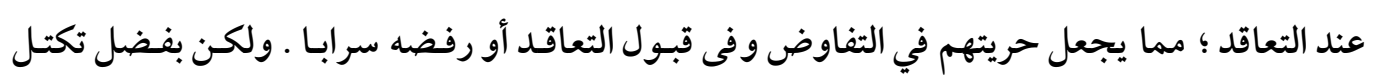

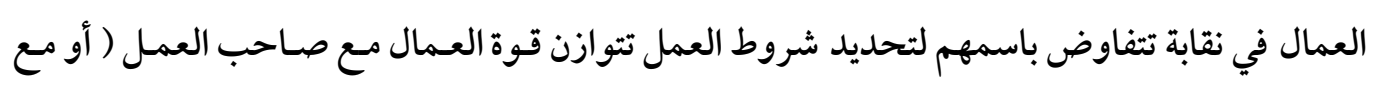
أصحاب الأعمال ) في مناقشة شروط العمل التى تبرم على مقتضاها عقود العمل الفردية .

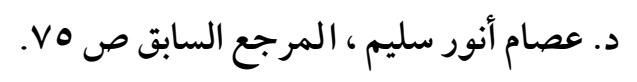

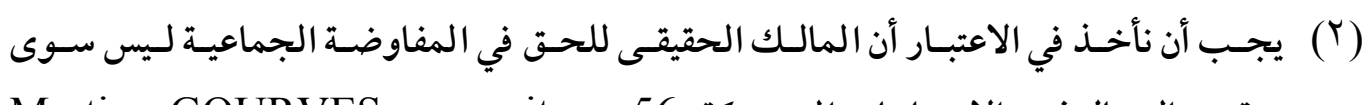

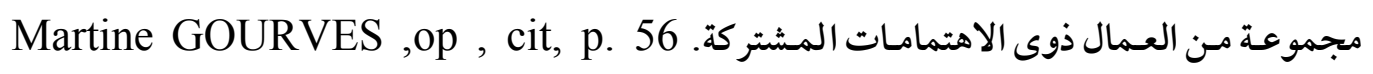


(llor)

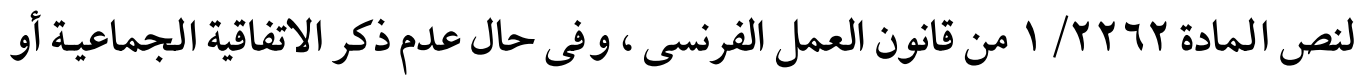

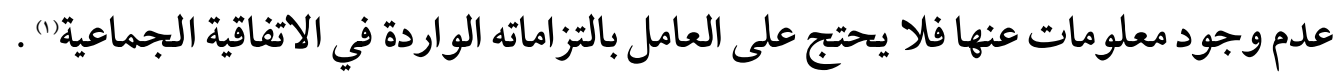
ويتم تحديد شروط إبلاغ العمال وممثليهم عن القانون التعاقدي المعمول به في الشركة

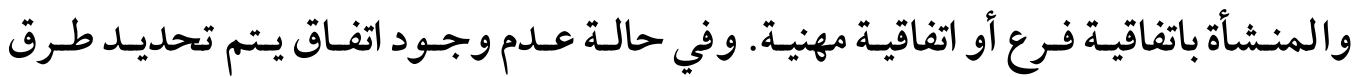
المعلومات المتعلقة بالنصوص التعاقدية المعمول بها من خلال اللوائح").

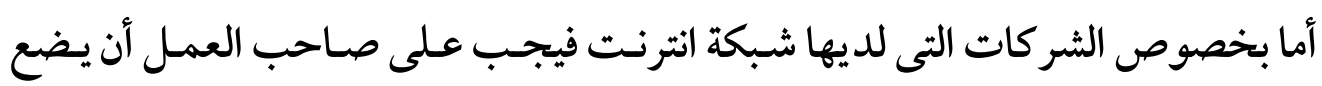
عليها نسخة محدثة، تكون متاحة للعاملين ، من اتفاقية العمل الجماعية التى يلتزم بها.

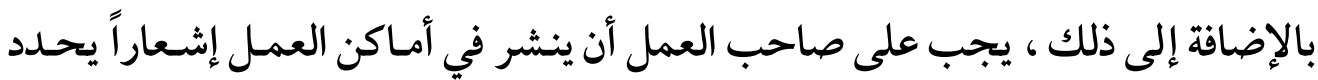

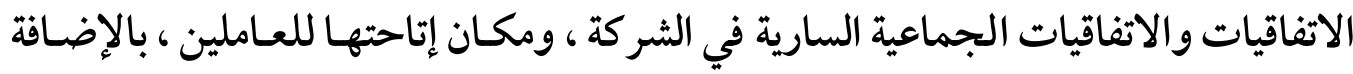
إلى الشروط والأحكام التي تسمح باستشار تهم ، في نسخة حديثة ، أثناء ساعات العمل وفي (ت) مكان العمل ويعاقب على عدم عرض الاتفاقية الجماعية بعـدم قابليـة تنفيذ أحكامها ضـد العـمال

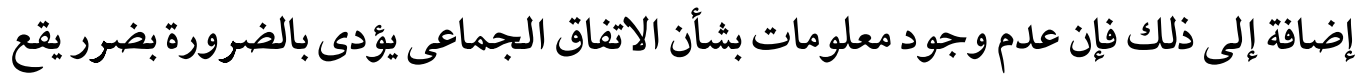

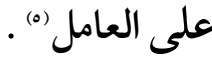

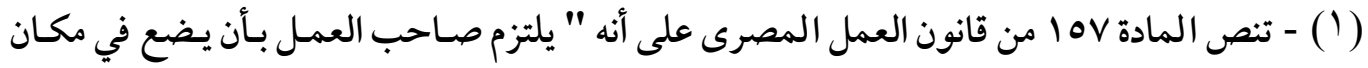

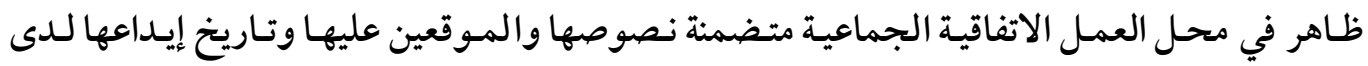

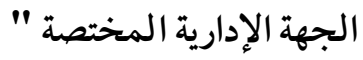

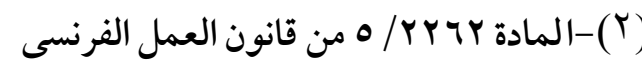
(r) (4)- Martine GOURVES ,op , cit, p. 70 - Cass.Soc 26/09/2002, Jurisdata $\mathrm{n}^{\circ}$ 2002-015600. Cass. Soc 14/02/96 Légi social $\mathrm{n}^{\circ} 7426$. Cass. Soc 30/10/97 Légi social

(5)- A.Lepage ,op,cit,p.145 - Soc., 19 mai 2010, pourvoi no 09-40.265 . 


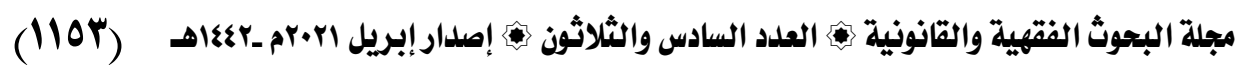

ويبجب أن تقدم هذه المعلومات في غضون شهرين من بداية العمل ، لا سـيما مـن خلال

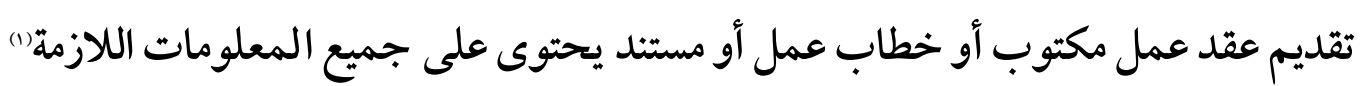

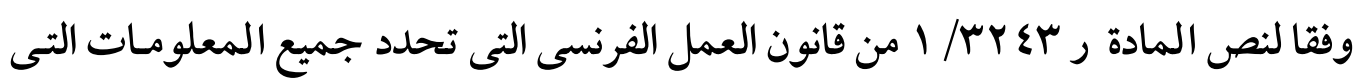
يجب أن تكون موجودة بقسيمة الراتب(") وإذا كـان شرط تطبيـق الاتفــاق الجماعـى مـرتبط بمعرفـة العامـل المـسبقة لمعلومـات

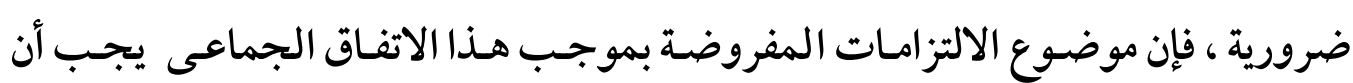

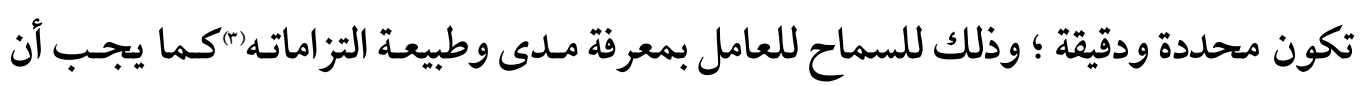
يكون لهذه الالتزامات هدف محتمل ، بمعنى أنه يمكن للمدين تحقيقه ، وفقا للقول المأثور

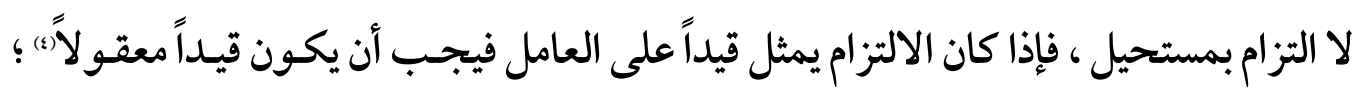
لذلك يمكن الطعن في شرعية بعض الالتزامـات التى تـرد في الاتفـاق الجماعى إذا كانـت تفرض التزامات إضافية تقيد حقوقهم الأساسية والحريات الفردية أو الجماعية(ه) . على العكس من ذلك يمكن عن طريق الاتفاق الجماعى إعطاء حقـوق للعـاملين أفضل مما في القانون() ،حيث إن الاتفاق الجماعى لـه الأسبقية في التطبيق عـلى قـانون العمل إذا كانت الأحكام الواردة فيه أكثر ملاءمة للعامـل ، عـلى سبيل المثـال مـنح إجـازة للمناسبات العائلية أكبر من عدد الأيام التى نص عليها قانون العمل "(v) .

(1)- A.Lepage ,op,cit,p.145

(Y) يتعين على صاحب العمل إبلاغ العامل في قسيمة الراتب بالاتفاقية الجماعية المعمول بها

(3)- Martine GOURVES ,op , cit, p. 65 Objet 144

(4)- Ibid

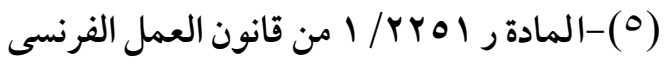

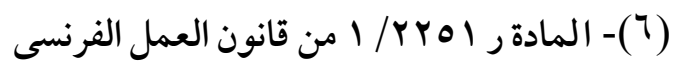

(7)- Martine GOURVES ,op , cit, p. 65 Objet 145 
$(110 \xi)$

كما ينطبق نفس الشئ بخصوص عقد العمل (1) ، حيث يكون للاتفاق الجماعى الأسبقية

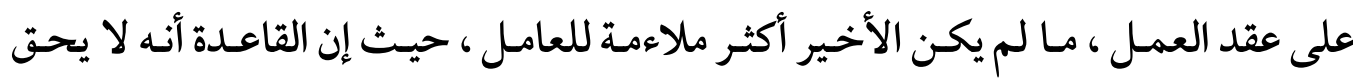

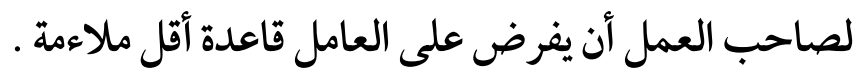

ومع ذلك فإنه فيما يتعلق بالاتفاق الجماعى بالحفاظ على العمالة وتطويرها ، فإن الاتفاق الجماعى يكون ملزما للعاملين بغض النظر عما إذا كان عقدهم يحتوى على بنود أكثر فائدة ،

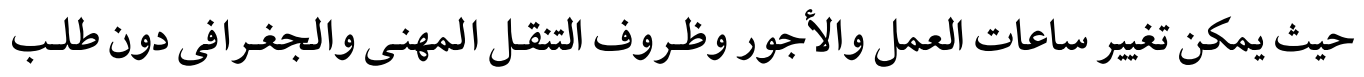

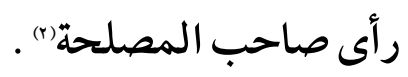

كذلك يمكن أن تكون معلومات العامل حول الاتفاقية الجماعية المعمول بها مصددرا

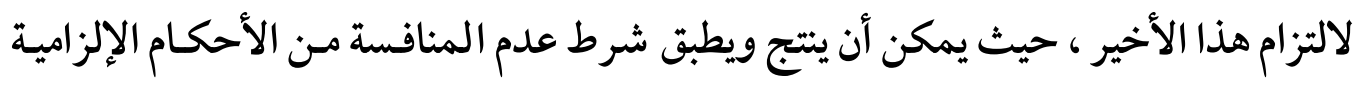
للاتفاق الجماعى إذا كان قد تم إبلاغ العمال بوجود الاتفاقية السارية وتمكينهم من الاطلاع

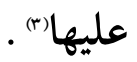
وكـذلك الحـال بـشأن وجـوب إنفـاذ التـزام التنقـل النصوص عليـه مـن خـلال الاتفـاق الجماعى () ، حيث يمكن لصاحب العمل الاعتماد على هـذا الالتزام الموجود بالاتفاقية الجماعية في حال عدم وجود شرط التنقل في عقد العمل ؛ وذلك عندما يكون نص الاتفاقية كافيا في حد ذاته ، وتم إبلاغ العامل بوجود هذه الاتفاقية الجماعية وقت ارتباطه بعقد العمل

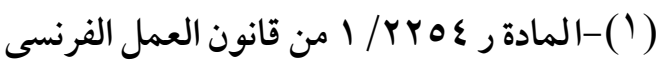

$$
\begin{aligned}
& \text { (Y) }
\end{aligned}
$$

(3)- A.Lepage ,op,cit,p.145-146 - la Cour de cassation dans un arrêt du 8 janvier 1997Bull.civ. V nº 8 - Soc., 9 juillet 1976, Bull. 1976, V, no 451, pourvoi no $75-40.662$

(4)- Martine GOURVES ,op , cit, p. 65 Objet 152 


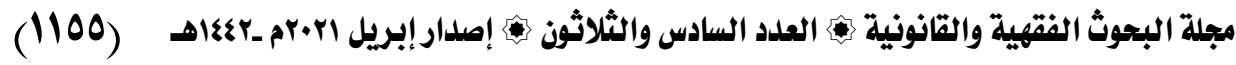

، ووضعه في وضع يسمح له بالتعرف والاطلاع على الاتفـاق الجماعى وبنوده" وبخاصـة

البنود الضرورية المتعلقة بشروط ممارسة شرط التنقل وتحديد المنطقة الجغر افية (r).

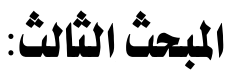

\section{حق العامل في المعرفة أثناء تنفيذ عقد العمل}

إن التبعية و التسلسل الهرمسى ، سواء أكـان قانونيـا أم اقتصاديا ، يطوقان علاقـات العمل الفردية إلى حد تحويلها إلى مبارزات تهدف إلى تر جمة تنافس المصالح سواء أكانت تلك الخاصة بالعمال أو الخاصة بصاحب العمل.

كـذلك لا يمكـن إنكـار أن نجـاح صـاحب العمـل مـرتبط برفاهيـة العامـل ؛ إذ إن تحـالف المصالح هو الذى يجب أن يختم عقد العمل ، والذى يجب أن تحدث في هدوء وسكينة ، حيث يجب على كل شريك أن يمكن الآخر من تنفيذه بأفضل الطرق الممكنة (r). ومع ذلك فإن علاقات العمل غالبا ما تتميز بوجـود حوارات سـاخنة وقنوات للتوترات : فنجد صاحب العمل لديه دائما رغبة مستمرة في تعديل علاقة العمل والتى قد يقابلها رفض من العامل (s) ، كذلك هو حال العامـل بـصفته طرفـا تعاقديا يمكـن أن يكـون لديـه الرغبـه في تعديل عقد عمله ، وذلك دون أن يشكل هذا في حد ذاته سوء سلوك مهنى معاقب عليه (ه . .

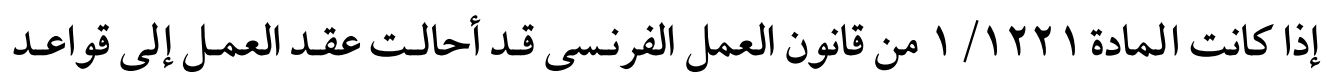
العقد الواردة في القانون المدنى ، وهذا يعنى أنه لا يمكن فرض أى تعديل على عقـد العمل

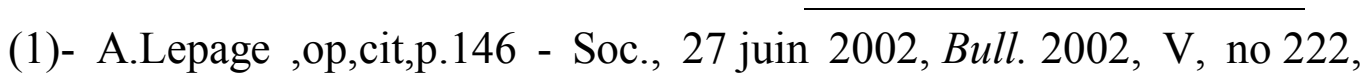
pourvoi no 00-42.646

(2)- A.Lepage ,op,cit,p.146 - Soc., 24 janvier 2008, Bull. 2008, V, no 23, pourvoi no 06-45.088

(3)-Alexandre BARÈGE, L'éthique et le rapport de travail, 2008, p. 275

(4) - Léa Amic, op, cit , p.459 Objet 678

(5)- Martine GOURVES ,op , cit, p. 135 - Cass. Soc . 14/11/89, Cahiers prud'homaux $1991 \mathrm{n}^{\circ} 4$ 
$(1107)$

سواء من القاضى أو من أى من المتعاقدين بإرادة منفردة ، وإنما لكى يـتم التعـديل واستبدال

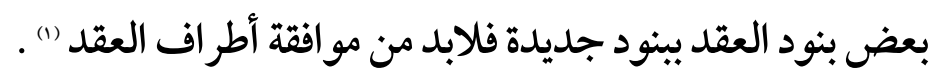

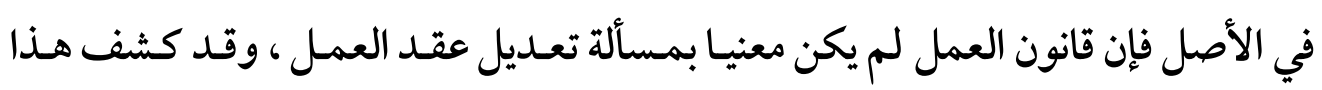

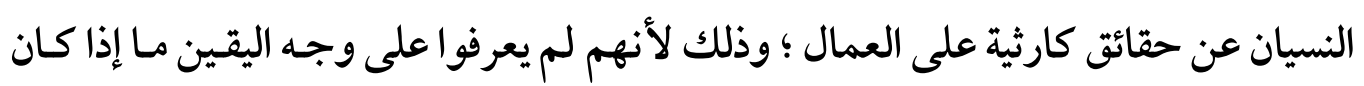

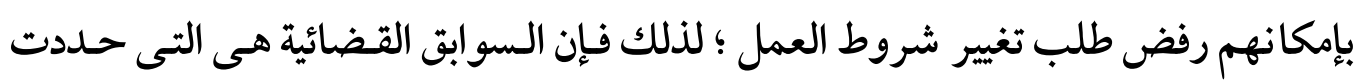
قو اعد التعديل في عقد العمل مستهدية في ذلك باستخدام قواعد القانون العام للعقود (") .

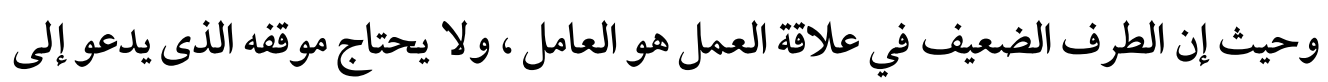

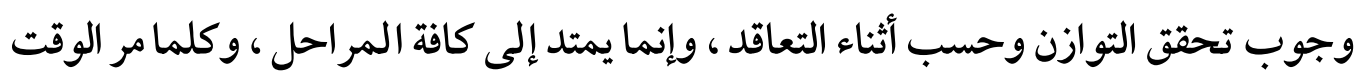

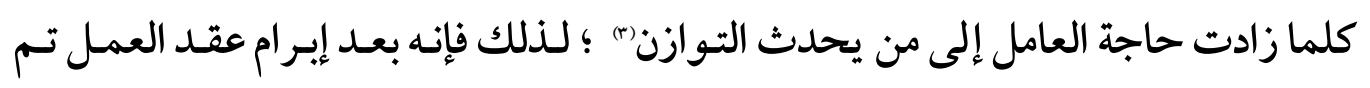

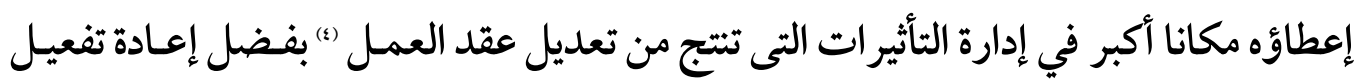

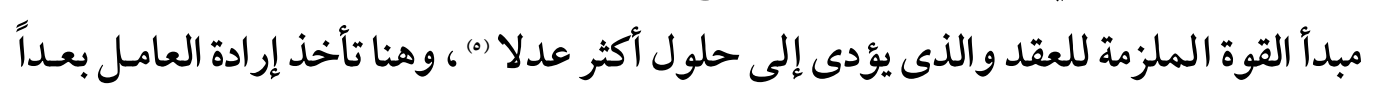

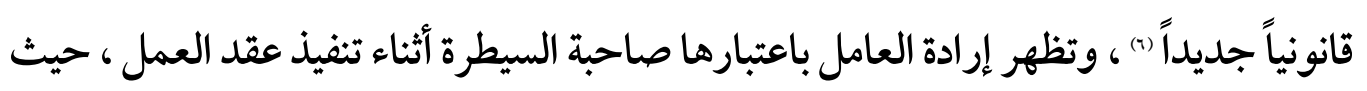

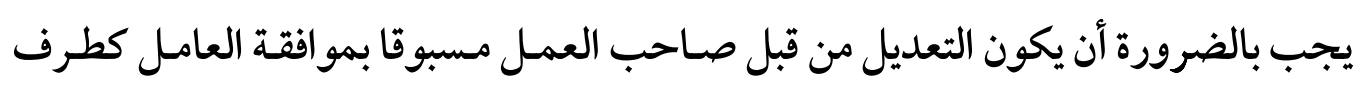

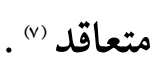

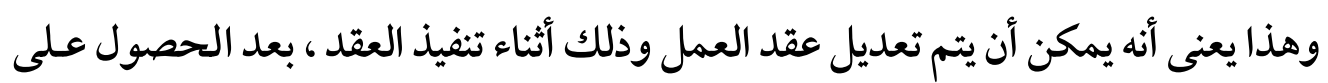
مو افقة العامل ، بتعديل عنصر من عناصر عقد العمل مثل المنطقة الجغر افية أو مدة العمل .

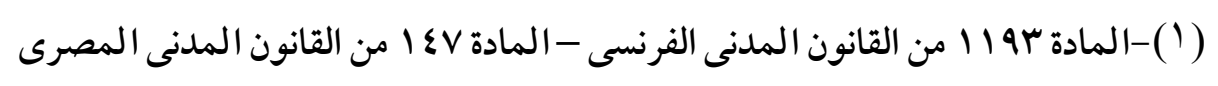

(2)-Franck PETIT, la modification du contrat de travail, Le Droit Ouvrier• AOÛT2016・ $n^{\circ} 817$. P.483

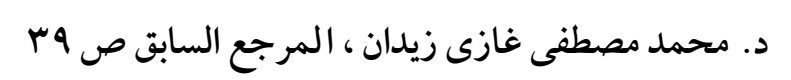

(4) - Martine GOURVES ,op , cit, p. 129 Objet 257

(5) - Serge Diena Diakiese,op,cit,p.9

(6)- Martine GOURVES ,op , cit, p. 129 Objet 257

(7)-Ibid, p. 143 Objet 283 - Cass. Soc 11/07/01, Bull.civ. V 2001 n 264 


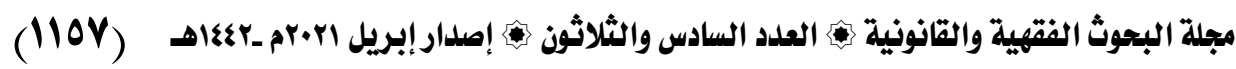

ومع ذلك فإن الحاجة إلى الحصول على قبـول العامل في كـل تعـديل يجعـل الإدارة في موقف صعب في كل مرة ؛ لذلك ظهرت فكرة وضـع البنود التعاقديـة المسبقة وذلك أثنـاء صياغة عقد العمل ، فحو اها الحصول مسبقا على قبول العامل لفكرة تعديل عقده ، وأوضـح الأمثلة على مثل هذه البنود إدراج بند حرية التنقل ضمن نصوص عقد العمل والذى يسمح لصاحب العمل بالحصول مسبقاً على موافقة العامل على تغيير مكان العمل "(1).

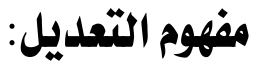

إذا كان تعديل عقد العمل يتطلب ضرورة موافقة العامل ، إلا أنه ليس كل تعديل أو تغييير في ظروف العمل يتطلب دائما هذه الموافقة ، وإلا فإننا نتعـدى عـلى سـلطة صـاحب العمل الإدارية في إدارة وتنظيم مؤسسته ؛ لذلك نجد السوابق القضائية أنشأت التمييز بين التغييرات الجوهرية والتغييرات غير الجوهرية :

بخصوص التغييرات الجوهرية فهى تلك التى تنطلب مو افقة العامل والتى تتعلق بتعـديل ومراجعة العناصر الأساية لعقد العمل كالأجر والقطاع الجغرافى وسـاعات العمـل وغيرهـا من العناصر الأساسية لعقد العمل ، وكـذلك الحـال إذا كـان تعـديل عقـد العمـل يـؤدى إلى لى الإخلال بالظروف المعيشية للعامل (r) .

أما التغييرات غير الجوهرية وهى المتعلقـة بـالتغيير في ظـروف العمـل ، فهى تقـع تحـت السلطة الإدارية لصاحب العمل ، ولا يتطلب موافقة العامل عليها ، حيث إنها تقع تحت فكرة التبعية لصاحب العمل ؛ لذلك يجب أن يقبل العامل ما يـأمره بـه صـاحب العمل أثنـاء تنفيذ عقد العمل ، كما أن رفضه يعد خطأ يستوجب العقاب التأديبى (r) .

د. همام محمد محمود زهران المرجع السابق ص ع ا I - Franck PETIT, op,cit,P.483

(2)- Serge Diena Diakiese,op,cit,p. 20

(3)- Léa Amic, op, cit , p.445 Objet 679 - Soc. 29 janv. 2014, n 12-27724 (au sujet de la modification du lieu de travail) ; Soc. 23 mai 2013, $\mathrm{n}^{\circ} 12$ - 
$(110 \Lambda)$

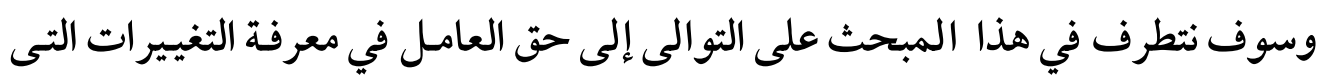

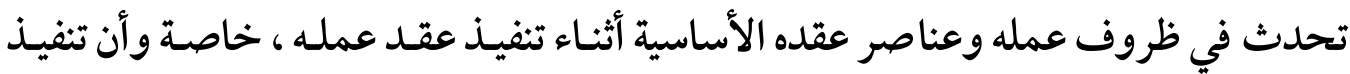
عقد العمل يقع تحت سلطة توجيه وتنظيم صاحب العمل والذى سيكون مقيدا بحظر إسـاءة

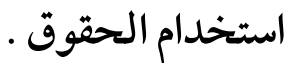

\section{اـحق العامل في معرفة التفييرات في أجره}

يعد الأجر الذى يتقاضاه العامل مقابل للعمل عنصر ا أساسيا في عقد العمل (1) ، ولا يمكن

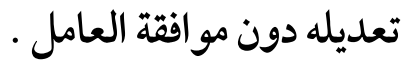

فلا يمكن لصاحب العمل تعديل الأجر المتفق عليه في بداية التعاقد بين الطرفين ولو إلى لى لهون

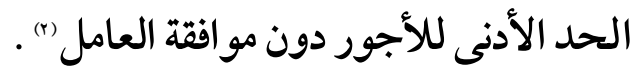

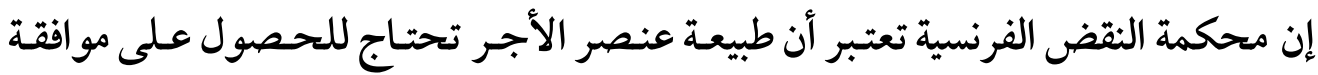

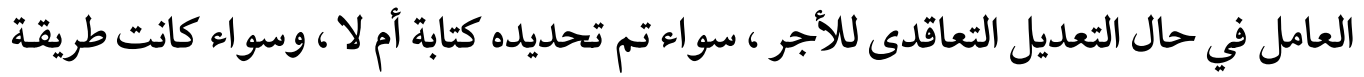

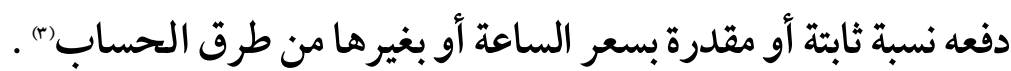

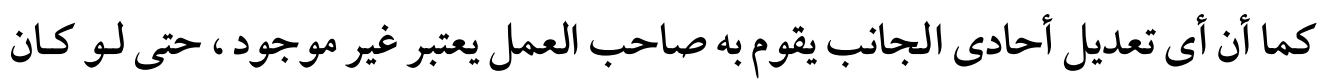

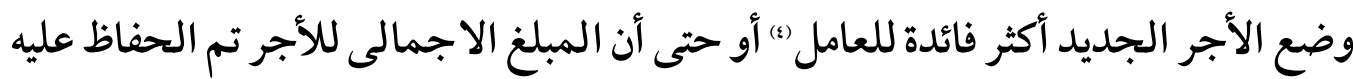

12995 (une discrimination avérée) ; Soc. 29 janv. 2014, n 12-23789 (le non paiement d'éléments de salaire).

(1) - Serge Diena Diakiese,op,cit,p.20.

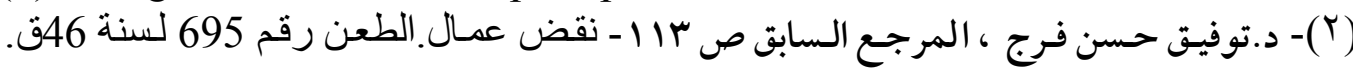

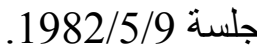

(3)- Martine GOURVES ,op , cit, p. 139 - Cass. Soc 03/03/98, Dr. Soc. 1998 p 523. Cass. Soc 09/12/98, RJS 1999 n ${ }^{\circ}$ 45. Cass. Soc 18 / 04/00, D. 2000 info rapides p 41. Cass. Soc $18 / 04 / 00$, JCP G 2000 Actualité p 895. Cass. Soc 03/07/01, Liais. Soc. 16/07/01 jp n ${ }^{\circ} 730$. Cass. Soc 17/10/01, Liais. Soc. 29/10/01 jp n 738

(4)- Martine GOURVES ,op , cit, p. 140 - Cass. Soc. 18 oct. 2006, ${ }^{\circ}$ 05-41.643 


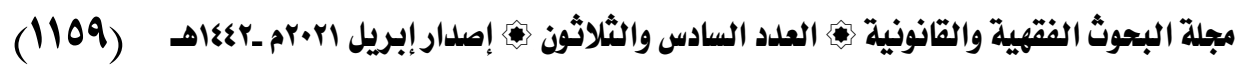

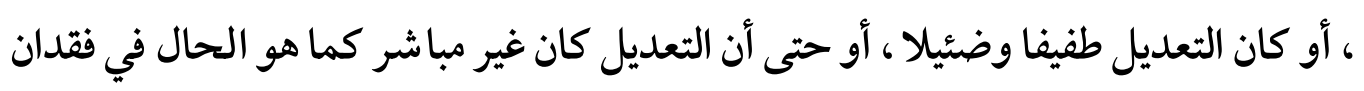

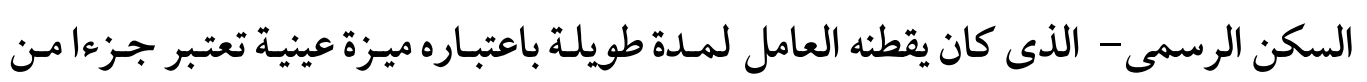

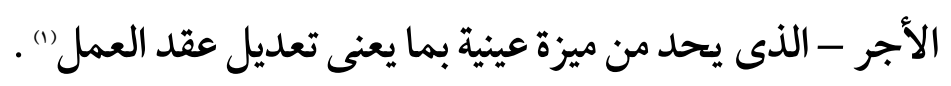

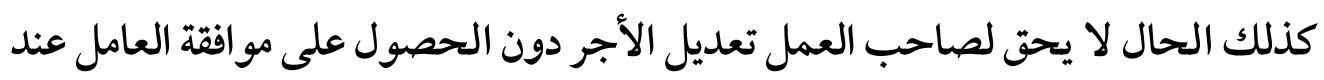

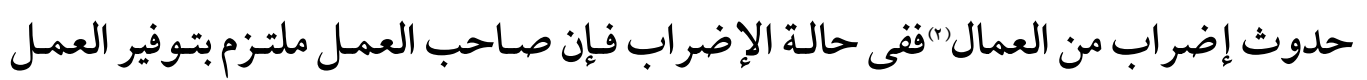

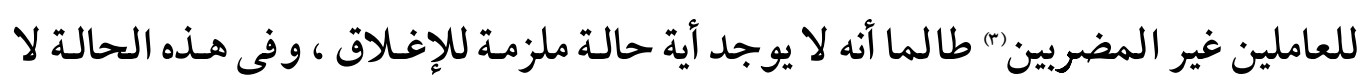

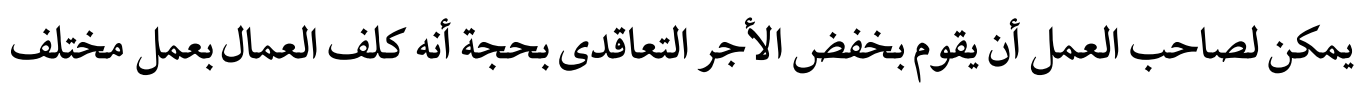
عن العمل الذى يؤدونه عادة. كذلك فإنه حتى لو كان هناك بند تعاقدى يمنح صاحب العمل سلطة تعديل الأجر كليا أو

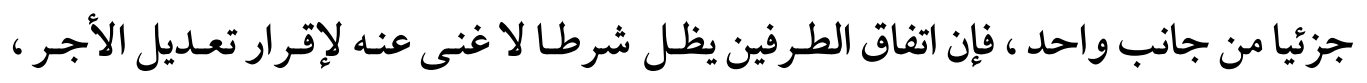

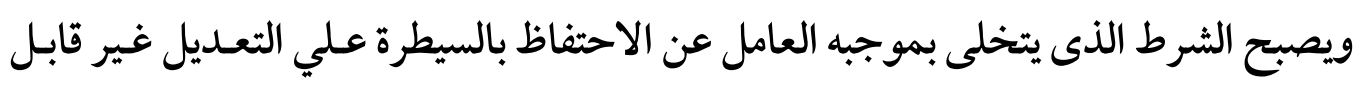

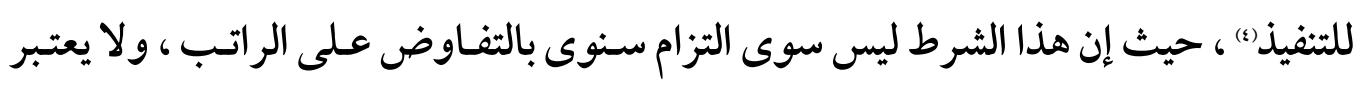
تعبير اعن السلطة السيادية لصاحب العمل في تعديل الأجر (o).

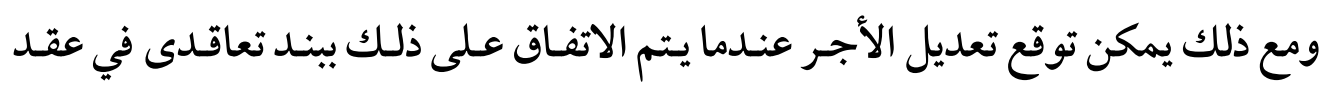

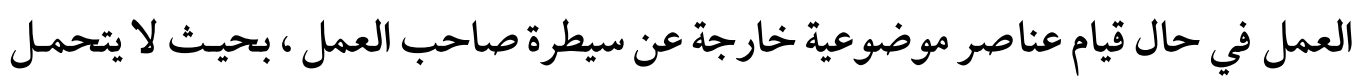

(1) - Cass. Soc. 14 nov. 2007, JCP S 2008, 1078, n. B. Bossu

(2)-Martine GOURVES ,op , cit, p. 140 - Cass. Soc 4/10/00, Dr. Soc.12/12/00 p 1156.

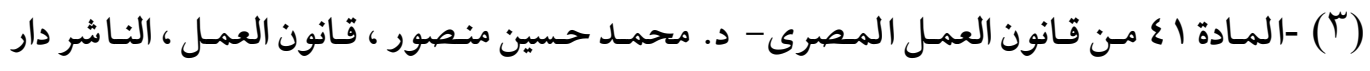

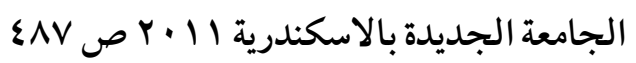

(4)- Serge Diena Diakiese,op,cit,p.24 - Cass. Soc., 27 fév. 2001, Dr. soc. 2001, p. 514, n. C. Radé ; M. FabreMagnan, préc.

(5)- Serge Diena Diakiese,op,cit,p.24 
(117.)

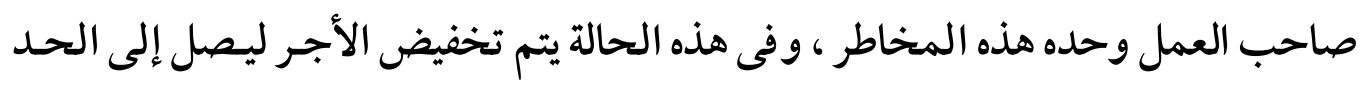
الأدنى القانونى أو التعاقدى الذى تم الاتفاق عليهـ" . .

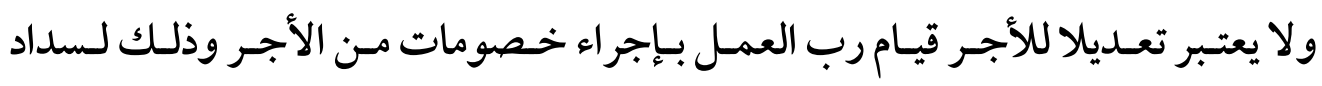

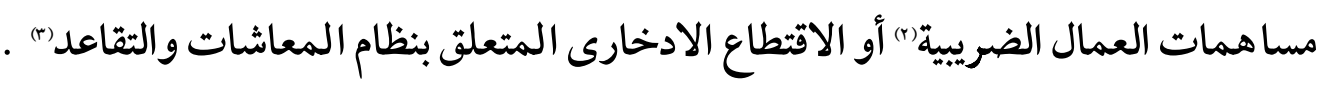

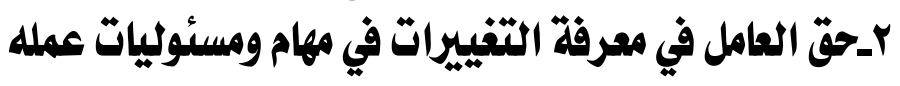

إن العمل المثفق عليه يشكل البطاقة المهنية للعامل ، ويعد اعتر افـا تعاقديا بمهارات العامل وخبراته وسبيا للتعاقد معه ، وهو سبب التزام صاحب العمل بدفع الأجر (s).

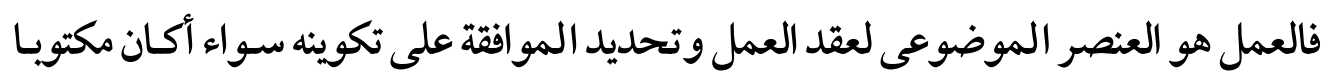

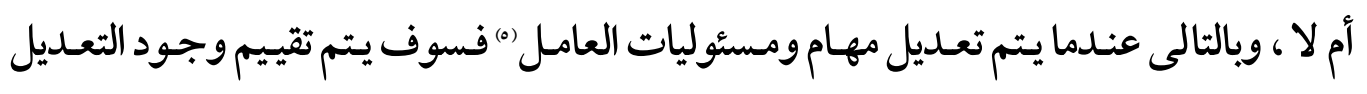

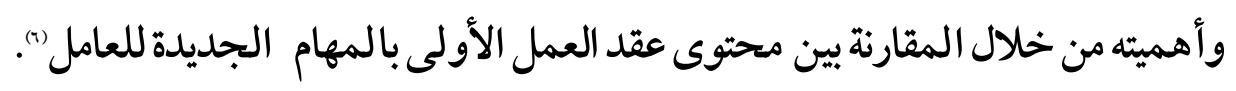

(1)- Cass. Soc., 4 mars 2003, M. c/ société Comptoir général ameublement, $\mathrm{n}^{\circ}$ 01-41.864.

(2) - Serge Diena Diakiese,op,cit,p. 25

(3)- Ibid

(4) - Martine GOURVES ,op , cit, p. 137 Objet 276

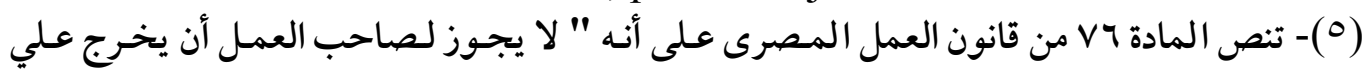

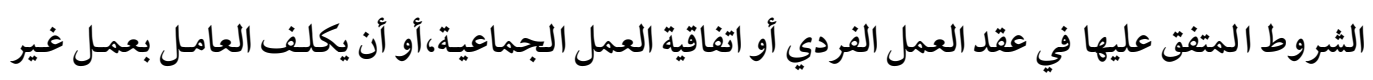

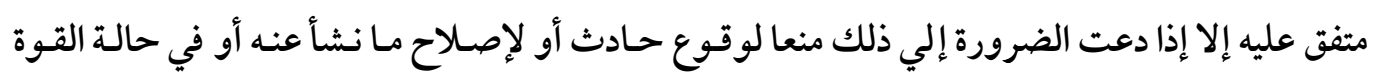

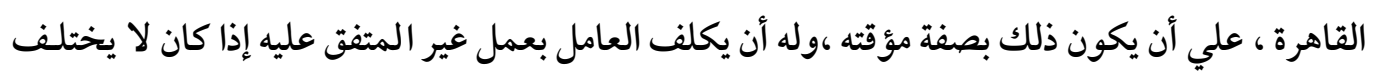

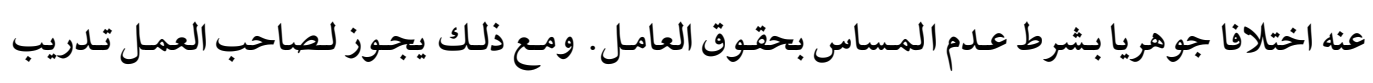
العامل وتأهيله للقيام بعمل مختلف يتماشي مع التطور التقني في المنشأة .

(6)- Serge Diena Diakiese,op,cit,p.26

قضت محكمة النقض المصرية بأنه " وإن كان لرب العمل السلطة في تنظيم منشأته أو إعـادة تنظيمها

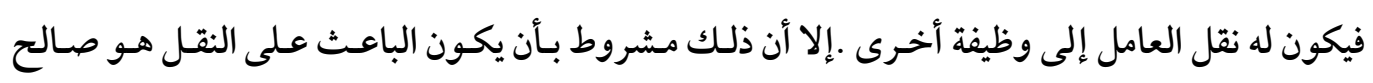

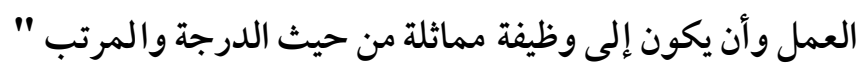




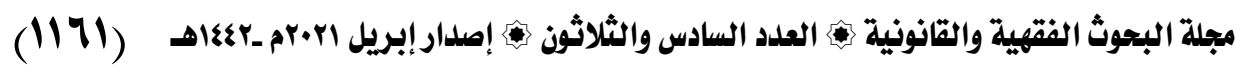
ستؤخذ المهام السابقة في الاعتبار عند تحديد ما إذا كان هناك تعديل على العقد بعد تغيير مهام الوظيفة أم لا ، فعلى سبيل المثال فإن تخفيض الدرجة المهنية يعتبر بمثابة تعـديل عـلى عقد العمل (1) إذا تسبب في تقليل صلاحيات العامل ومسئولياته() حتى ولو تـم الحفـاظ على لى

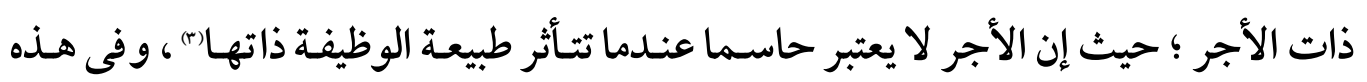
الحالة فإن موافقة العامل مطلوية وبالتالى يكون للعامل الخيار بـين قبـول أو عـدم قبـول مثل هذا التعديل على وظيفته (s). كذلك فإن موافقة العامل مطلوبـة حتى إذا تـم خفضـ الدرجـة المهنيـة بعـد اقتر اح إعـادة التصنيف من جانب صاحب العمل بسبب العجـز النـاتج عـن مرض أو حـادث غير مهنى ، حيث يحق للعامل رفض حل إعادة التصنيف (o). ولا يعتبر تعديلا لعقد العمل تغيير المهام الوظيفية مع الحفاظ على المسئوليات والأجر (ج) ، وبنفس الطريقة إذا تم تكليف العامل بمهام مختلفة عن تلك التى تم تنفيذها سابقا إذا كانت تتو افق مع مؤهلاته(v) أو إذا كان هناك ظروفا استثنائية تبرر أداء مهام دون مستوى التأهيل ، وقد يؤدى رفض التنفيذ من جانب العامل إلى عقوبات تأديبية).

"التعـويض في حالـة نقـل العامـل لوظيفـة أقل ميزة أو ملاءمـة عنـد عـدم قيـام حالـة الضـرورة أو القـوة القاهرة"

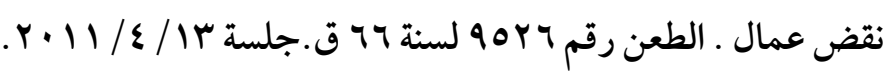

(1) - Serge Diena Diakiese,op,cit,p.26- Cass.Soc . 09/04/, Liais. Soc. 22/04/2 jp n ${ }^{\circ} 765$. Cass. Soc 14/06/00, Bull. civ V 2000

(2) - Cass. Soc , 30 mars 2011, appel no 7182409

(3)-Serge Diena Diakiese,op,cit,p.26- rVq دمام محمد محمودزهران ، المرجع السابق صمون

(4)-Martine GOURVES ,op , cit, p. 138 Objet 276

(5) - Ibid

(6) - Serge Diena Diakiese,op,cit,p.26

(7) - Ibid - Cass. Soc 23juin 2010, appel $n^{\circ} 08-45368$.

(8) - B. Boubli : Sur les modification du contrat de travail et la loi Aubry Semaine sociale Lamy $1998, \mathrm{n}^{\circ} 849$ 
$(117 r)$

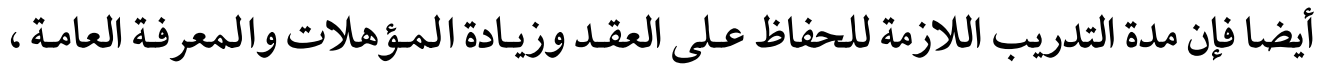

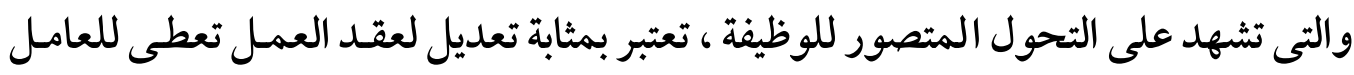
الحق في إمكانية رفض هذا التدريب"). بخصوص الترقية فيرى بعض الفقه أنها لا يمكن أن تؤدى إلى تعديل عقد العمل ؛ وذلك فيك

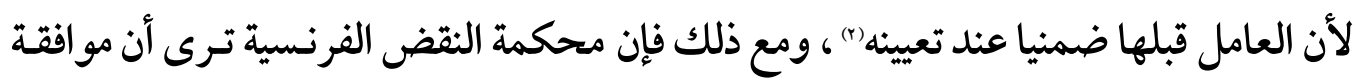
العامل ضرورية في حالة الترقية وعلى وجه الحصوص إذا كانت هـذه الترقية تنطوى على دئى

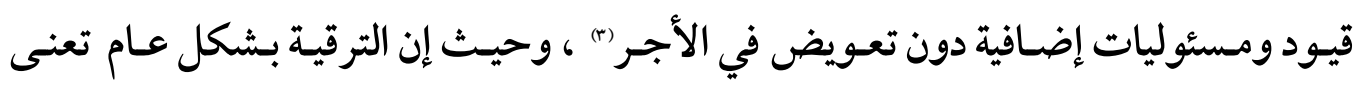

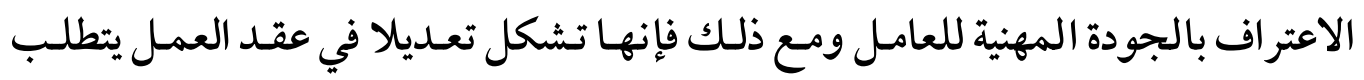

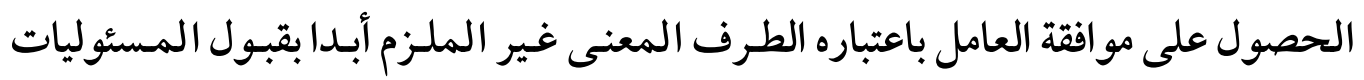

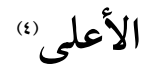

\section{r_حق العامل في معرفة تطورات مكان العمل}

سبق أن ذكرنا أن مكان العمل ليس في حـد ذاته عنصرا من العنـاصر الأساسية في عقدـ العمل ، ومع ذلك فإنه في حال عدم ذكر معلومات عن مكان العمل فإن مكان العمل سيرتبط

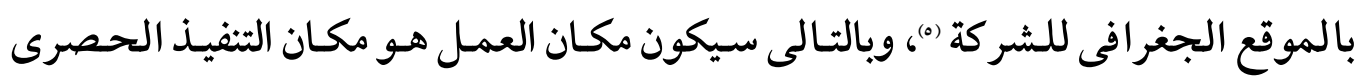
للنشاط الاقتصادى للشر كة).

(1)- Serge Diena Diakiese,op,cit,p.27

(2) - B. Boubli, op.cit. n 849

(3)-Martine GOURVES ,op , cit, p. 138 - Serge Diena Diakiese,op,cit,p.27- Cass. Soc 16/12/98, RJS 2/99 nº 154.

(4) - Martine GOURVES ,op , cit, p. 137-138 Objet 276

(5)- Ibid, p.144 Objet 286

(6)- Henrik de Brier,op,cit,p.90 Objet 130 


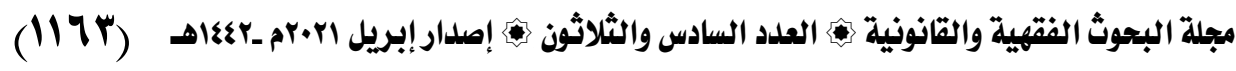
وعلى ذلك فإن تغيير مكـان العمل يعتبر تعـديلا في عقـد العمل عنـدما يستلزم تغيـير في المنطقة الجغر افية ؛ لذلك يجب موافقة العامل على مثل هذا التعديل .

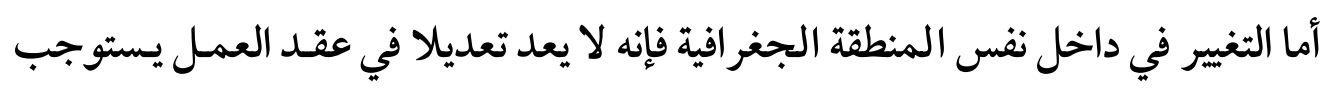
مو افقة العامل ، وإنما هو مجرد تغيير بسيط في ظروف العمل (1) ، ومـع ذلك فيإذا كـان عقـد العمل قد نص ببند واضح ودقيق على أن يؤدى العامل عمله حصريا في المكان الذىى يـذكر بعقد العمل ، فقى هذه الحالة يشكل أى تغيير في مكان العمل بما في ذلك التغيير في نفس القطاع الجغر افى تعديلا لعنصر أساسى في عقد العمل ، ولا يمكن فرضه على العامل (r). قد يتفق طرفا عقد العمل كتابة على أن العامل يو افق مقـدما عـلى العمل خــارج المنطقـة الجغر افية المحددة ، فيما يعـرف بشرط التنقل (r) ، في هـذه الحالة يجـب أن يحـدد شرط التنقل المنطقة الجغر افية الجديدة بدقـة شـديدة ، وعندما يريـد صـاحب العمـل تطبيق هـذا الشرط فيجب على العامل الامتثال لأمر النقل (s) ، بشرط أن يكون في ذات المنطقة المحددة

(1) - Henrik de Brier,op,cit,p.90 Objet 130- Martine GOURVES ,op , cit, p. 149 Objet 287 - Cass. soc., 16 décembre 1998, $\mathrm{n}^{\circ}$ 96-40227, obs. in P.WAQUET - Cass. soc. 3 mai 2006, appel no 41880-04

(Y)- في سياق مكافحة فيروس كورونا فإنه من المتوقع أن يتم فرض نشاط جزئى على العامل المحمى

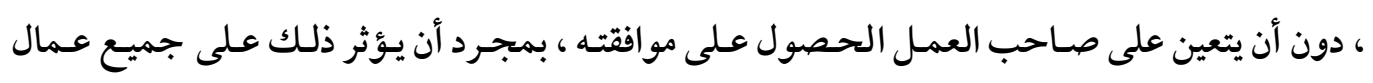
الشر كة أو المؤسسة التى تم تعيين الشخص المعنى بهـا ، وهـذا الحكـم الانتقـاصى موجـود في القـانون

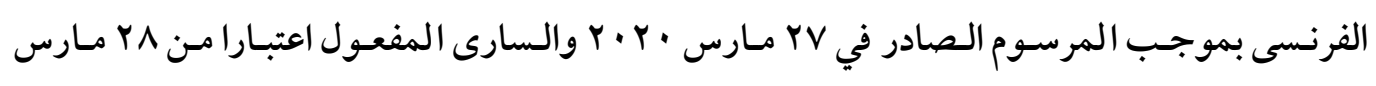

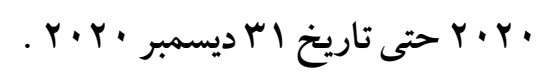

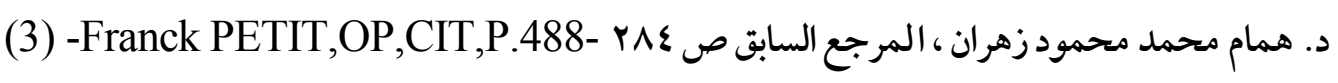

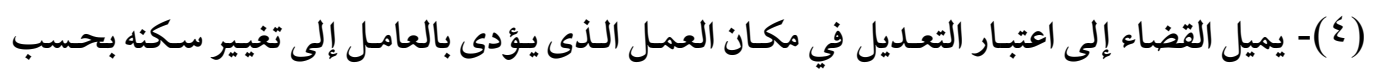
الأصل تغييرا جوهريـا ، إلا أن شرط حرية التنقل يستفاد من طبيعة نشاط المشرورع أو طبيعة المهام

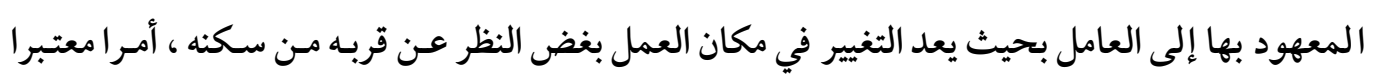

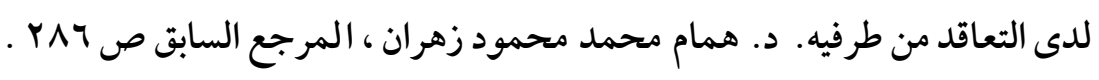


(117ร)

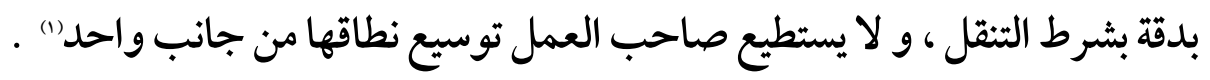

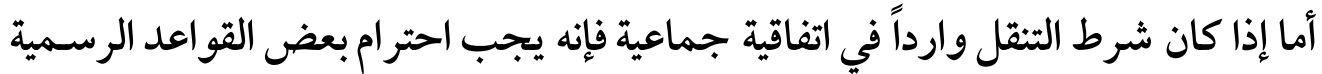

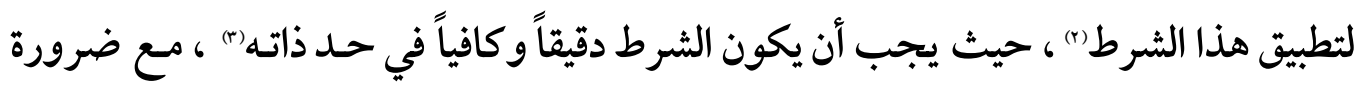

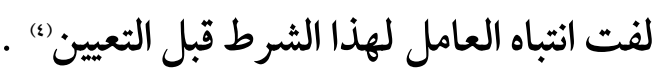

كذلك فإن التنقل في الظروف الاستثنائية يعتبر قانونيا إذا كان مرتبطا بمصلحة العمل ،

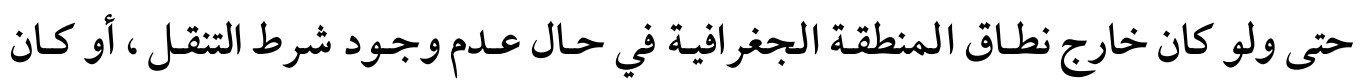

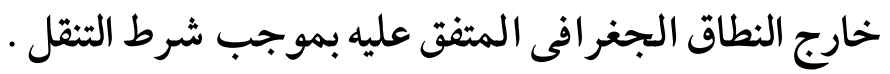

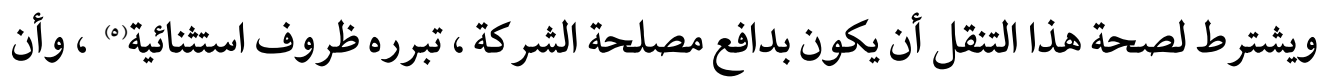
يتم إبلاغ العامل مقدما خلال فترة معقولة تفصل المعلومـات عن التنفيذل() ؛ حتى يستطيع التكيف مع الظروف الواقعية.

(1)- Cass. Soc. 12 juil. 2006, $\mathrm{n}^{\circ}$ 04-45.396)- (Cass. Soc. 7 juin 2006, $\mathrm{n}^{\circ}$ 04-45.846, Dr. Ouv. 2006, p. 529-Cass. Soc. 14 octobre 2008, $\mathrm{n}^{\circ}$ 06-46.400.

(2)- Henrik de Brier,op,cit,p.94.

(3)- Ibid - cass. soc., 24 janvier 2008, $\mathrm{n}^{\circ}$ 06-45088, obs. J. SAVATIER, Dr. soc., 2008, p. 498

(4)- Henrik de Brier,op,cit,p.94

(5)- Ibid,p.92 Objet 135 - conditions de validité, note sous cass. soc. 3 février 2010, RDT, 2010, p. 226

(6)- Léa Amic, op, cit , p.487 Objet 722

رفض العامل لقبول تنفيذه التنقل دون اعتبار الإشعار المنصوص عليه في الاتفاق الجماعي لا يشكل

خطأو لا يمكن إضفاء الشرعية على الفصل التأديبي(Soc. 15 nov. 2006, no 05-41772)

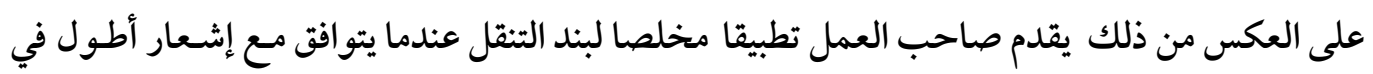

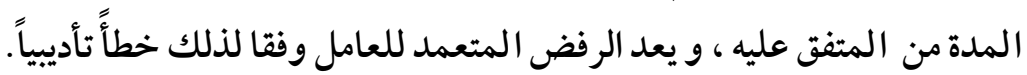

(Soc. 28 févr 2001, Bull. civ. V, n 259)- Soc. 14 oct. 2008, no 07-4307Soc. 21 juin 2006, no 04-44866 ; Soc. 3 juin 1997, no 94-43476 (en l'espèce, deux semaines pour une mutation de Marmande à Pau) . 


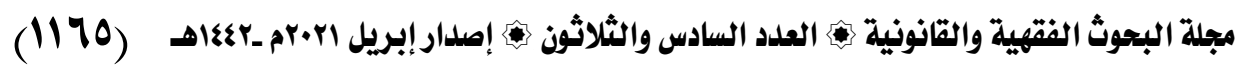

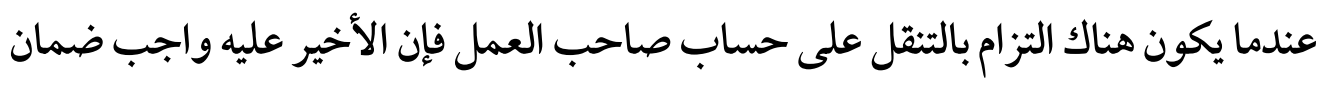
تكيف العاملين مع تطور وظائفهم إذا لزم الأمر عن طريتق التدريب وإعـادة التصنيف داخل

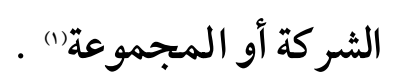

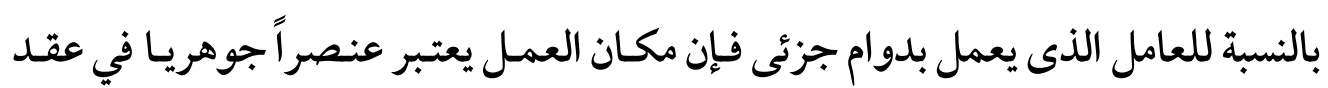
العمل (r) ، وبالتالى لا يمكن تعديله دون مو افقة العامل . أما بخصوص السفر في بعض الأحيان خارج المنطقة الجغر افية فإنه لا يعتبر تعـديلا في ولي

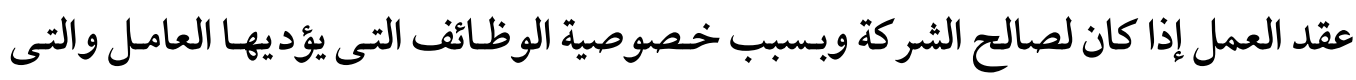

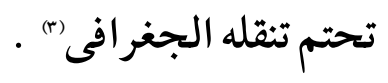
بخصوص تغيير مكان العمل ، إذا كان التغيير جماعيا لجميع عمال المشروع تبعا لتغيير

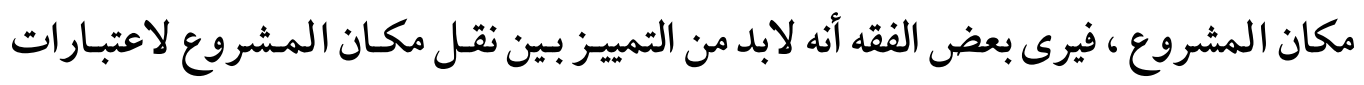
ترجع لصاحب العمل ومصلحة العمل ، شأن التوسع ونمو المشروع أو التمتع بإعفـاءات

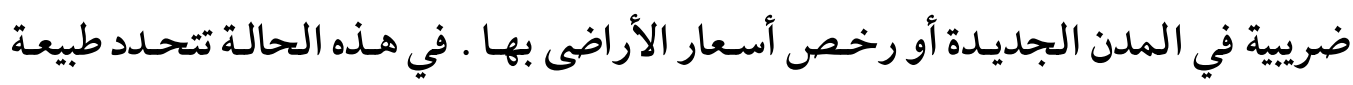

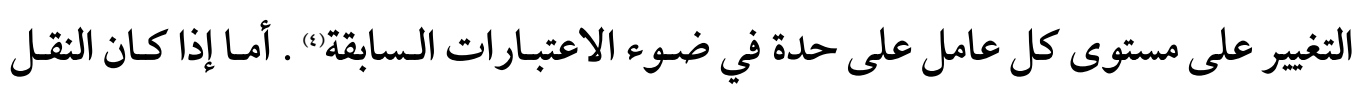

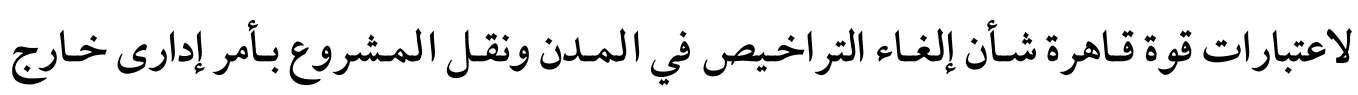

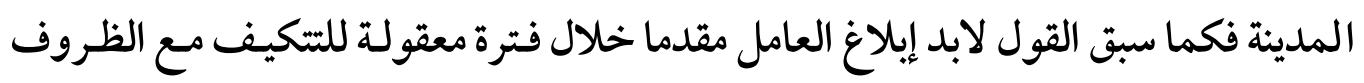
الواقعية وتفصل المعلومات عن التنفيذ.

(1)- Serge Diena Diakiese,op,cit,p.30

(2)- Serge Diena Diakiese,op,cit,p.29

(3)- Martine GOURVES ,op , cit, p. 146 Objet 290 - Franck PETIT,OP,CIT,P.489

السفر في بعض الأحيان خـارج المنطقة الجغرافية لا يعتبر تعـديل لعقدـ العمل، حيـما يكون مبرره

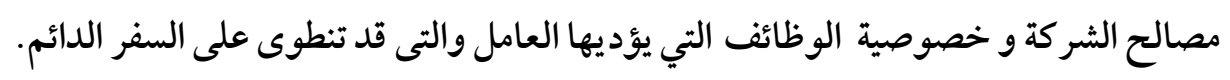
Cass. Soc., 22 janv. 2003, p. 433, obs. J. Savatier

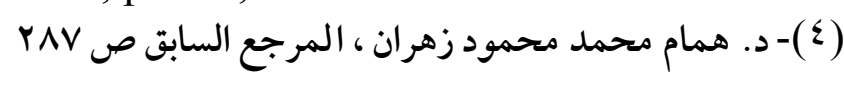


(1177)

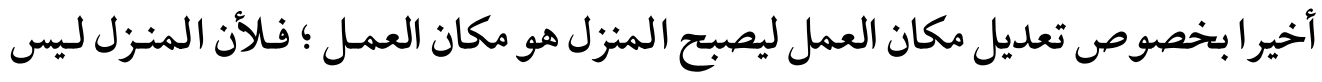

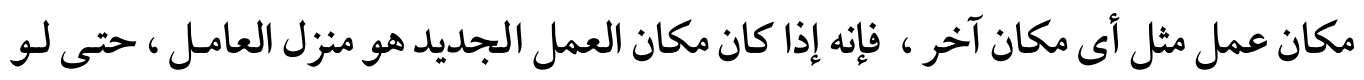

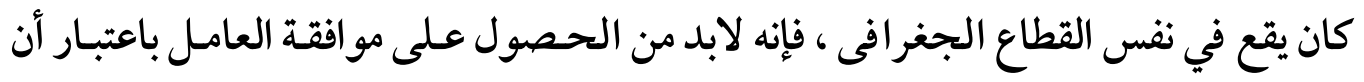

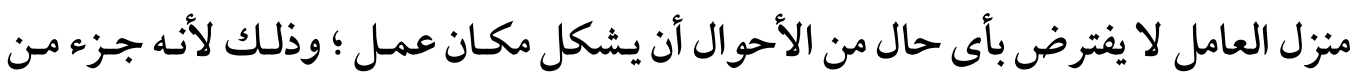

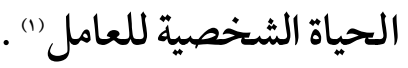

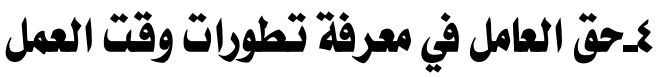

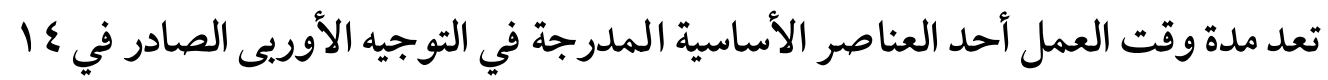

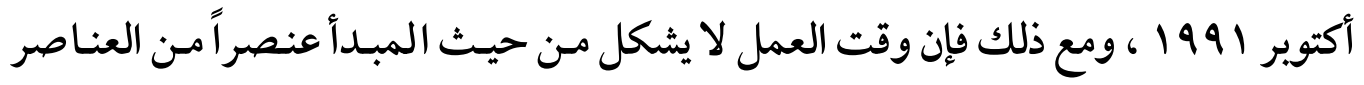
الأساسية لعقد العمل إلا إذا تم ذكره في عقد العمل (م) .

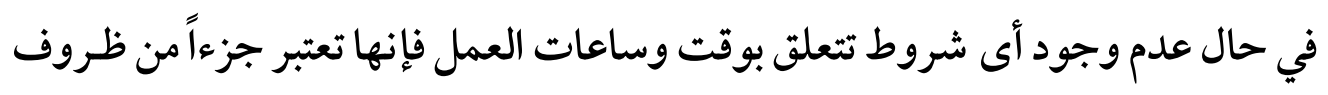

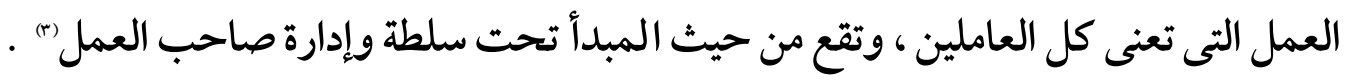

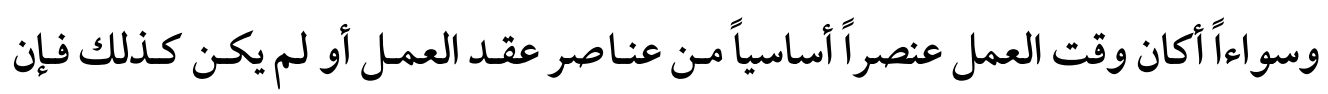
مسألة تغيير وقت العمل من قبل صاحب العمل أثناء تنفيذ عقد العمل سوف تفسر عمدر على عنى أنها تعديل لوقت العمل أو تغيير بسيط في ظروف العمل (s) .

(1)- Martine GOURVES ,op , cit, p. 146 Objet 290 - Cass. Soc 02/10/01,Jp soc. 2001,Ed. Legis - Cass.Soc. 31/05/2006, Liais.Soc.13/06/2006, jp n ${ }^{\circ} 962$.

(2) - P.H. Antonmattei : Les éléments du contrat de travail - Dr. Social

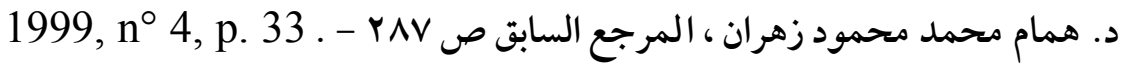

Martine GOURVES ,op , cit, - -

(4) - Serge Diena Diakiese,op,cit,p.43

Objet 177 p. 88 


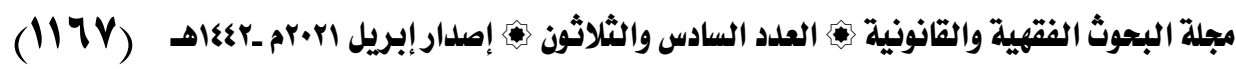

فإذا كان تحديد ساعات العمل الجديد ة تعديلا ضئيلا فسيتم تحليله على أنه تعديل

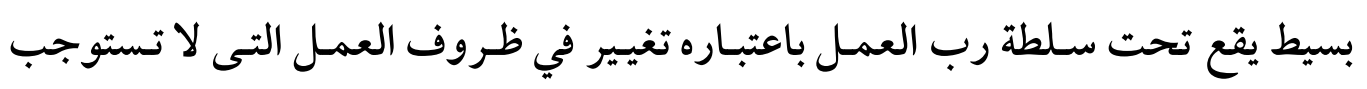

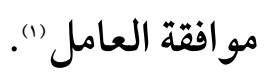

أما خفض ساعات العمل المنصوص عليها في عقد العمل فإنه يعتبر بالضرورة تعـديلا

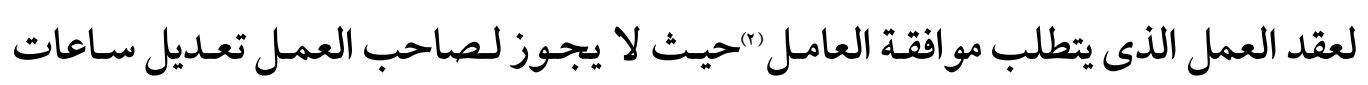
العمل بالزيادة أو النقصان دون موافقة العامل لتهل.

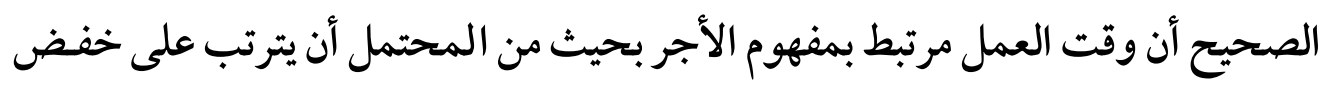

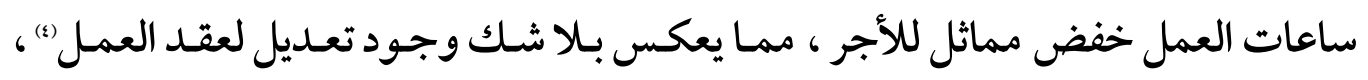
وينطبق نفس المبدأ على زيادة ساعات العمل حتى ولو كانت مصحوبة بزيادة الأجر (o) لماتل

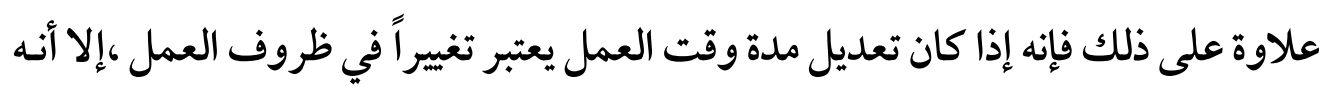

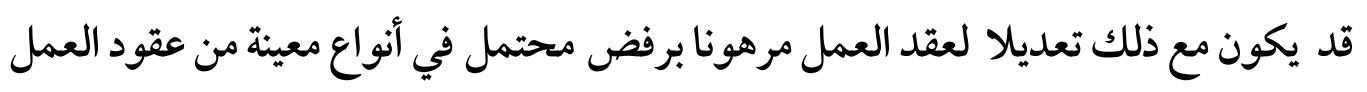

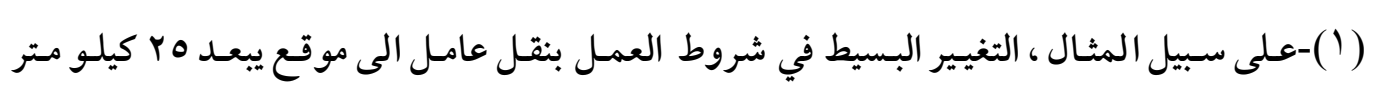

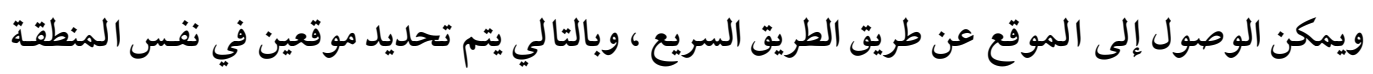

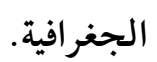

(Cass. Soc. 27 sept. 2006, $\mathrm{n}^{\circ}$ 04.47.005)

وانظر كذلك cass. Soc, 3 novembre 2011 No. 10-14.702

(2) - Martine GOURVES ,op , cit, p. 141 Objet 280 - cass. Soc 20/10/98 Dr. Soc. 1998 p 1045 et suiv. obs. Ph. Waquet

(3) - Martine GOURVES ,op , cit, p. 141 Objet 280

(4) - Martine GOURVES ,op , cit, p. 141 Objet 280 - Cass. Soc 16/02/99, Bull.civ. V 1999 n ${ }^{\circ} 72$.Cass. Soc 21/03/00, Liais. Soc. 03/04/00 jp nº 668 (5)- Martine GOURVES ,op , cit, p. 141 Objet 280 - Cass. Soc 10/03/98 BC n 124 , Dr. Soc. 1998 p 492 obs. Barthélemy 
(1171)

مثل : عقد العمل محدد المدة ، وعقد العمل بدوام جزئى أو بمعدل ثابت أو عقود العـاملين المحميين(1)

كما أن لصاحب العمل أن يجرى ما ير اه مناسبا لمصلحة العمل من تغيير أو تعديل لفترات

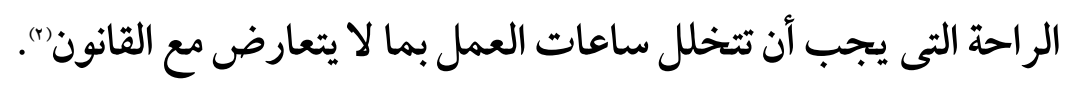

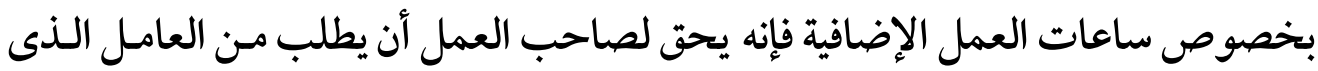

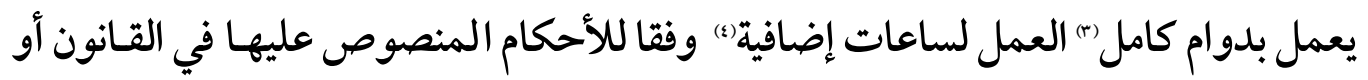

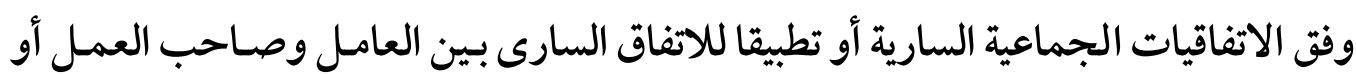

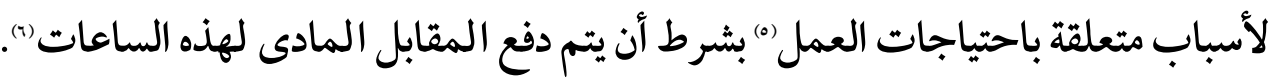

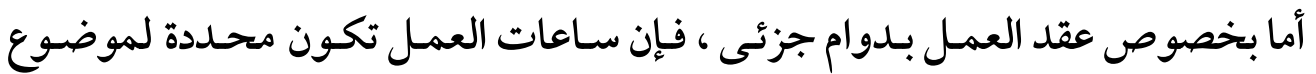
العقد") وبالتالى فإنه يحق للعامل رفض تنفيذ ساعات العمل الإضافية باعتبارها تعديلا لعقد (a) العمل

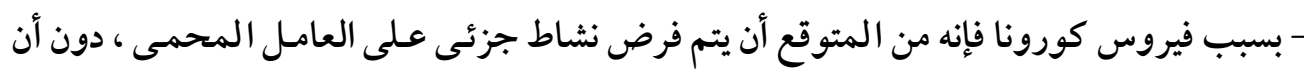

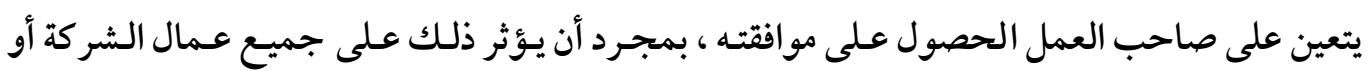

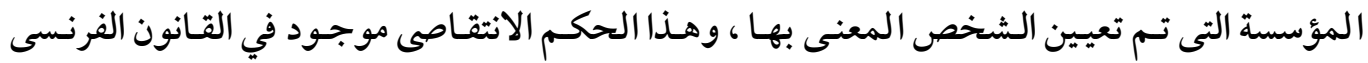

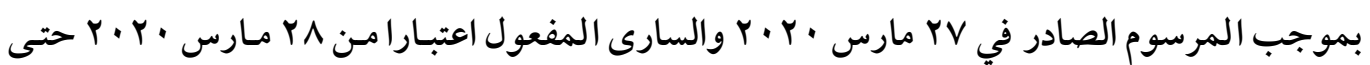
r.r. تاريخ الr ديسمبر

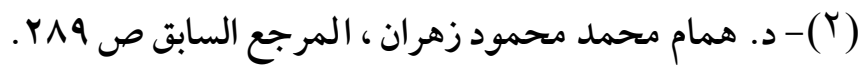

(3)- Martine GOURVES ,op , cit, p. 141 Objet 280

(4) - Ibid, p. 150 Objet 298

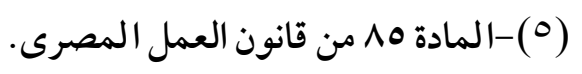

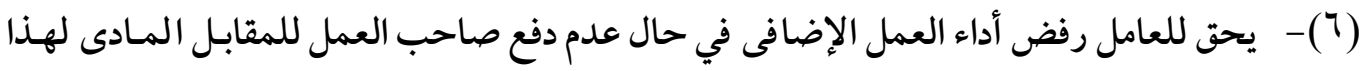
العمل Cass . Soc 07/12/99,Liais. Soc. 09/03/00 jp n n 665 (7)- Martine GOURVES ,op , cit, p. 88 Objet 177

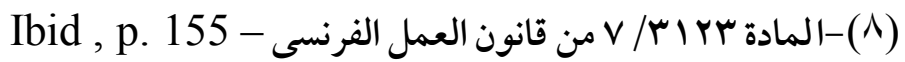




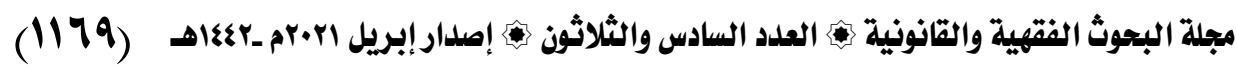
كذلك فإن بعض عمليات إعادة تنظيم وقت العمل تتوقف على طبيعة ومدى التعديل الناتج عنها ، و كذلك التوقع الدقيق للتحول العميق لاقتصاد العقد، وبالتالى تتطلب موافقة العامل ، ومن أمثلة ذلك : الانتقال من جدول ثابت إلى ساعات متغيرة') أو من وظيفة يتم العمل فيها نهارا إلى العمل الليلى (r) ، أو التغيير من جدول مستمر إلى جـدول غير مستمر (r)، وكذلك التعديلات على عدد أيام العمل في الأسبوع، أو إجبار العامل على العمل في أيام الإجازات() ، أو تحويل وظيفة بدوام دائم إلى وظيفة بدوام جزئى (o) . فنظر اللقيود التى تنطوى عليها التعديلات السابقة فإنه لابد من موافقة العامل المسبقة على

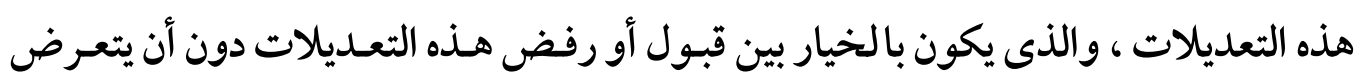
لعقوبة تأديبية. في عقد العمل بدوام كامل يمكن تغيير تنظيم وقت العمل من خـلال تطبيق نـص المـادة Y Y ا Y T من قانون العمل الفرنسى ، و فى هذه الحالة فإن تعديل وقت العمل لا يعتبر تعديلاً

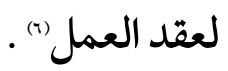
أما بخصوص عقد العمل بدوام جزئى فبإن هـذا العقـد يجـب أن يحتـوى عـلمى مجموعـة معلومات إلزامية(v) منها المدة الأسبوعية أو الثهرية وتوزيع أيام الأسبوع أو أسـابيع الشهر ،

(1) - Martine GOURVES ,op , cit, p. 88

(2)- Ibid, p. 142 - Serge Diena Diakiese,op,cit,p.43

- Cass.Soc. 13/12/2006, Liais. Soc. 27/12/06 arrêt en bref jp n 989.Cass. Soc 22/05/01, Liais. Soc. 05/06/0 jp n 721, Bull.civ.n ${ }^{\circ} 178$. Cass. Soc 27/02/01, Bull.civ V $2001 n^{\circ} 61$.

(3)- Martine GOURVES ,op , cit, p. 142 - Cass. Soc . 18/12/00, Liais. Soc. 09/03/02 jp n 708--Cass. Soc . 23/01/01, Bull.civ. 2001 V n¹9 p.12

(4)- Martine GOURVES ,op , cit, p. 142 - Soc 16/05/91, Dr. Soc. novembre 1994 p 856

(5) - Martine GOURVES ,op , cit, p. 142

(6) - Franck PETIT,OP,CIT,P.489 
(IIV*)

وهذه العناصر تعتبر جزءا من عقد العمل بدو ام جزئى ويجب أن تكون ثابتة في هذا العقددا" ، ولا يمكن تعديلها دون مو افقة العامل (").

بالتالى فإن خفض أو زيادة وقت العمل الأسبوعى أو الشهرى للعامل بـدوام جزئى يعتبر

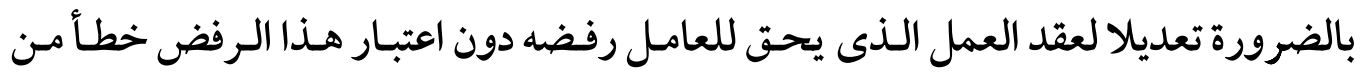

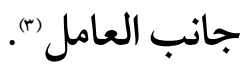
بالمثل فإن توزيع ساعات العمل يشكل عنصرا من عناصر عقد العمل بدوام جزئى والذى لا يمكن تغييره دون موافقة العامل (s). ولكى يتم تعديل هذا العقد يجب أن ينص عقد العمل على مبدأ التعديل المحتمل لتقسيم

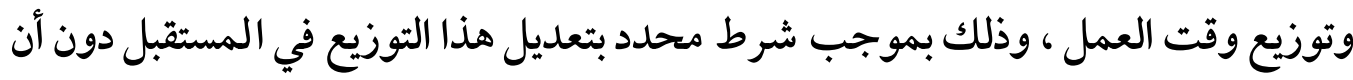

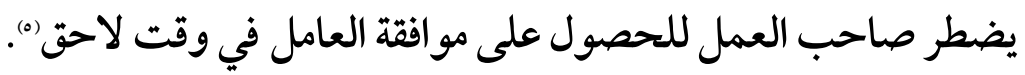

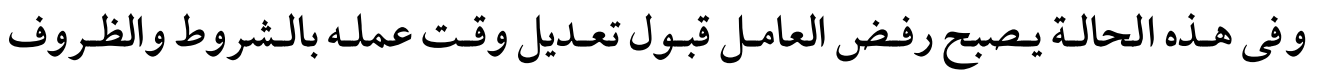
المحددة خطأ أو سببا للفصل . لماله وفى حال عدم وجود مثل هذا الشرط التعاقدى فإن العامل يحتفظ بحقه في رفض التغيير في ساعات عمله ولا يعد الرفض في هذه الحالة خطأ أو سببا للفصل (1) .

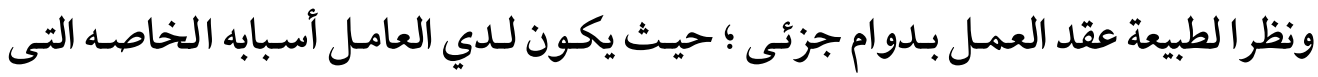
تضطره للعمل بدوام جزئى : كتوفير وقت للحياة الأسريـة والخاصـة ، والالتزامـات العائلية بـونية

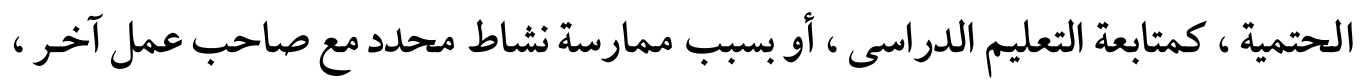

(1) - Martine GOURVES ,op , cit, p. 149 Objet 296

(2) - Ibid, p. 149 Objet 297

(3)- Ibid, p. 149 Objet 296

(4)- Ibid, p. 149 Objet 297 - Cass. Soc 07/07/98, Bull. civ. V n 373 ;Cass.

Soc . 06/04/99 Liais. Soc. 31/05/99

(5)- Martine GOURVES ,op , cit, p. 149 Objet 297.

(6)- Martine GOURVES ,op , cit, p. 150 . 


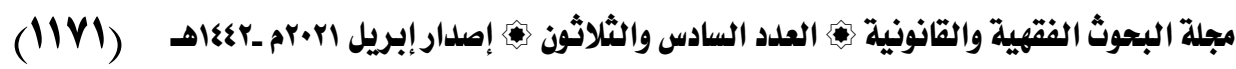

أو بسبب النشاط المهنى الخاص به ؛ لذلك حتى في ظل شرط مسبق بحق صـاحب العمل في تعديل توزيع قت العمل المنصوص عليه بعقـد العمل إلا أنـه يحـق للعامـل رفض هـذا التعديل بسبب التزاماته الأسرية الملحة") أو فترة نشاطه الثابتة سو اءاً للدى الغير أو لحسابه الخاص ، و لا يشكل لرفض في هذه الحالة خطأ أو سببا للفصل (r) . علاوة على ذلك فإن أى تعديل لا يتم تنفيذه فورا، وإنما يجب أن يكـون هنـاك فترة زمنيـة يحترمها صاحب العمل بين الإخطار والتنفيذ في حسال وجسود أى تغيير في توزيـع سـاعات العمل بين أيام الأسبوع أو أسابيع الشهر ، حيث يجب أن يتم إخطار العامل قبل التنفيذ بسبعة أيام على الأقل (r) ، ويمكن خفض هذه المدة إلى ثلاثة أيام في حال وجود حدث استثنائى (s) أما بخصوص تكليف العامل بالعمل لساعات عمل إضافية ، فكما سبق القول فـإن العامل بدوام جزئى يتمتع بالقـدرة عـلى رفض تنفيذها ، دون أن يشكل هـذا الرفض خطاً أو سـبيا للفصل ، وذلك عند عدم وجود بند تعاقدى ينص على استخدام العامل لساعات إضـافية ، أو كون الساعات الإضافية المطلوب من العامل أدائها تتجـاوز الحـدود المنصوص عليهـا في العقد (o) ، و كذلك عندما يتم إبلاغ العامل دون احترام فترة الإشعار . بالمقابل فإن رفض العامل العمل لساعات إضافية محددة بالعقد حسب الشروط القانونية المطبقة سيشكل خطأ قد يبرر الفصل (1) .

(1) - Franck PETIT,OP,CIT,P.491.

(2)- Martine GOURVES ,op , cit, p. 150 Objet 297- Cass. Soc . 07/07/98, RJS 10/98 n 1183 .

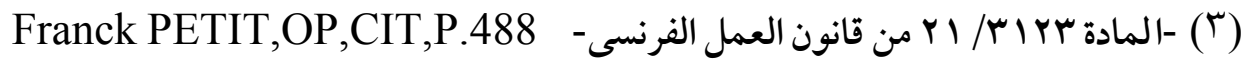
Martine GOURVES ,op , cit, p.150 Objet 297

(5)- Martine GOURVES ,op , cit, p. 150 Objet 298

(6)- Martine GOURVES ,op , cit, p. 150 Objet 298 
(livr)

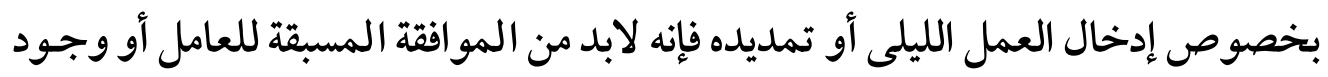

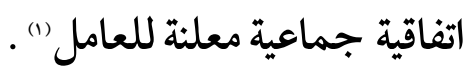
كما أن التغيير في الجدول الزمنى النهارى إلى الجدول الليلى يعتبر تعـديلا لعقـد العمل

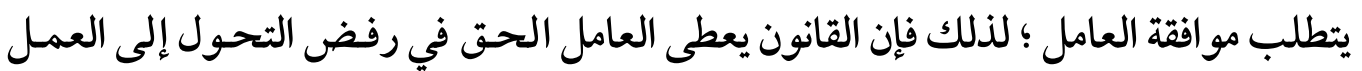

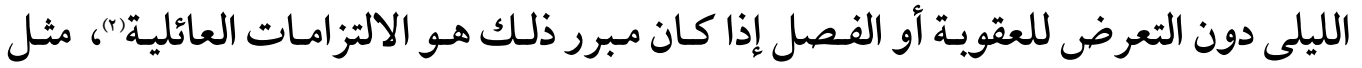

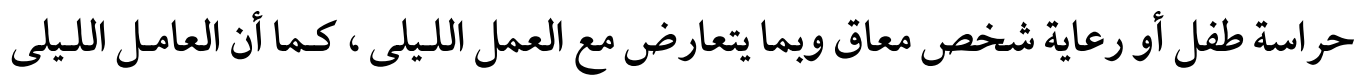
يمكنه كذلك أن يطلب تكليفه بوظيفة يوميـة نهاريـة إذا كان لديـه نفس الالتزامـات العـات العائلية

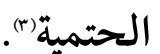

كما أن المشرع من أجل تسهيل إمكانية انتقال العاملين من جدول بدوام جزئى إلى جدول بدوام كامل أو العكس فقد أعطى أولوية لتخصيص وظيفة تنتمى إلى فئتهم المهنية أو العمالة

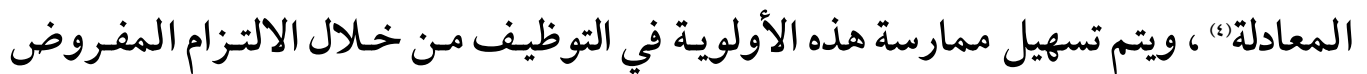

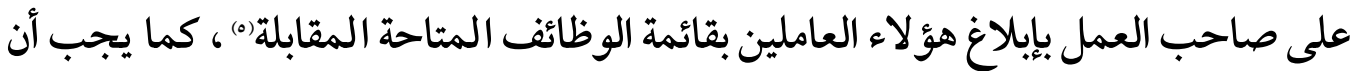
تخضغ هذه المعلومات للنشر المحدد فيما يتعلق بالوظائف التى قد تتوافق مع الفئة المهنية أو لوظيفة معادلة للعاملين بدوام جزئى الذين يرغبون في تولى وظيفة بدوام كامل أو للعاملين بدوام كامل الذين يرغبون في تولى وظيفة بدوام جزئى (1) .

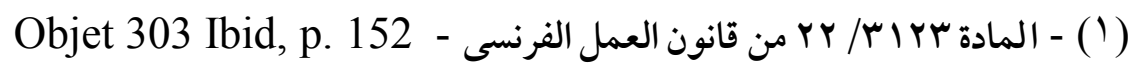
(2)- Martine GOURVES ,op , cit, p. 152 Objet 303

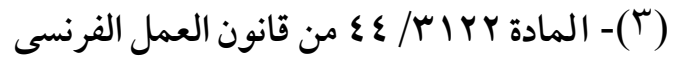

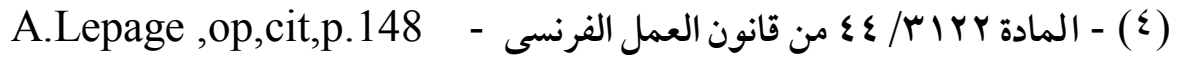

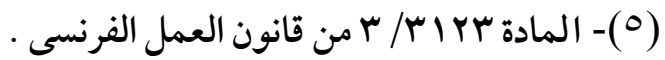
(6)- A.Lepage ,op,cit,p.148 - Cass. Soc . 23/01/01, Bull.civ. 2001 V nº19 p 12 


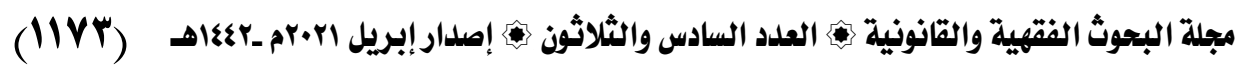
هـحق العامل في معرفة التفريرات في وضعه الجماعى

أثناء تنفيذ عقد العمل يمكن أن تطر أ الكثير من الأحداث التى تؤثر على تطبيت الاتفاقيات الجماعية التى يخضع لها العامل والثر كة أو المؤسسة التابع لها . فإذا كان تطبيق الاتفاق الجماعى ناشئ من الالتزام الأحادى مـن جانـب صـاحب العمل ، وهذا يعنى التطبيق الطوعى للاتفاقية الجماعية ، والذى قد يكون تطبيقا كليا أو تطبيقـا جزئيـا لبعض أحكام الاتفاق الجماعى "(1) . كما يمكن أن ينتج التطبيق الطوعى للاتفـاق الجماعى مـن بنـد محـدد في عقدـ العمل ،

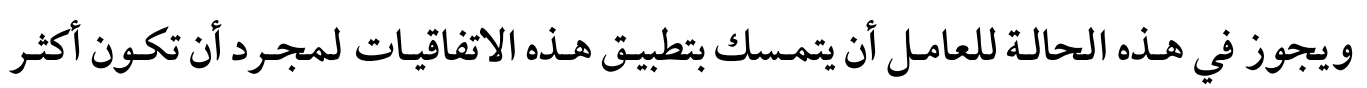

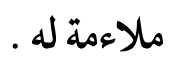
ومع ذلك فإن التطبيق الطوعى للاتفـاق الجماعى لا يعنى أن صـاحب العمل لديـه التزام

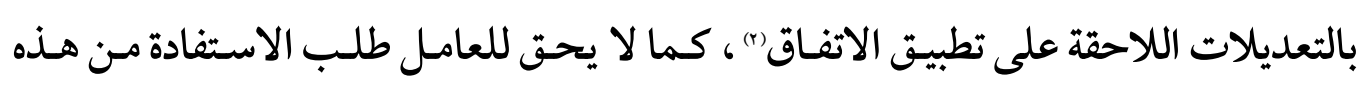
التعديالات

ومع ذلك فإذا رغب صاحب العمل في إنهاء تطبيت هـذا الاتفـاق الجماعى فـإن موافتـة العامل ضرورية ؛ وذلك لأن الأمر متعلق بتعديل عقد العمل وليس تغيير ا بسيطا في ظروف العمل (s)

( (1) - قد يتعلق تطبيق الاتفاق الجماعى ببعض العمال أو بعض الفئات ، وهذا التطبيق الطوعى لا يغطى جميع أحكام الاتفاق الجماعى. (r)

(3)- cass. SOC. , 20 décembre. 2006, $\mathrm{n}^{\circ}$ 05-40.292

(4)- cass.SOC. , Le 2 avril 2003, $\mathrm{n}^{\circ} 00-43.601$ 
(IIV\&)

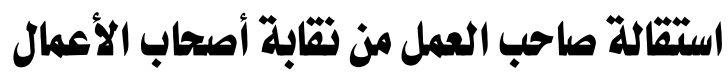

قد يحدث أن يستقيل صاحب العمل مـن نقابة أصحاب الأعمال ، في هذه الحالة فيان صاحب العمل سيلتزم بمواصلة تطبيق الاتفاقيات الجماعية الموقعة منه قبل استقالتها') ، مـن

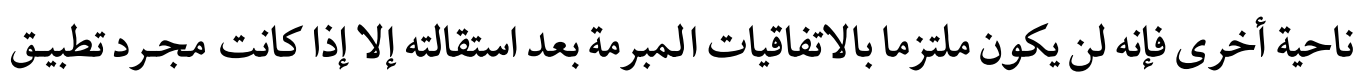

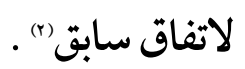

في هذه الحالة يجب على صاحب العمل المستقيل إبلاغ مجلس العمل وكذلك ممثلى

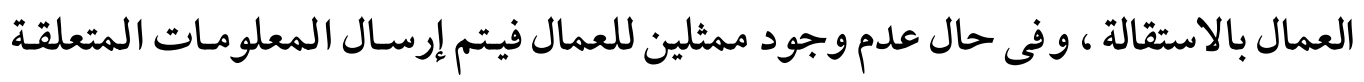
بالاستقالة إلى العمال أنفسهم" (r) .

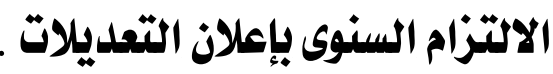

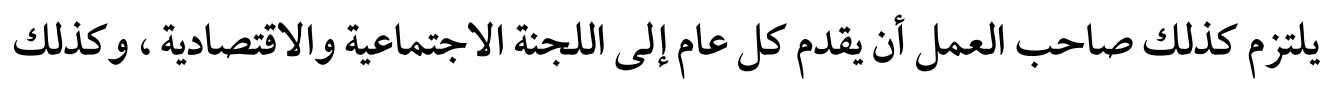

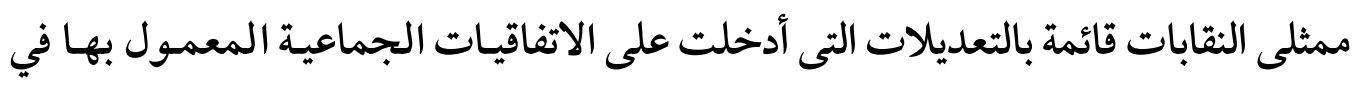

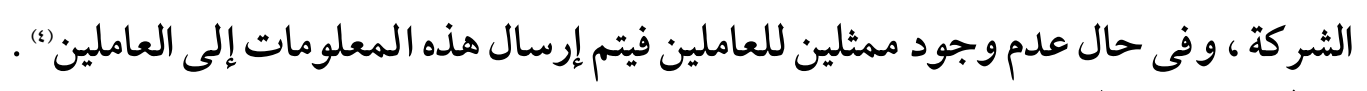

\section{أثر تفيير النشاط على الاتفاقيات الجماعية وجية}

إذا قام صاحب العمل بتغيير نشاط الشركة ، وكان هذا التغيير ينطوى على تطبيق اتفاقية جماعية أخرى فسوف يستمر سريان الاتفاقية الجماعية السابقة حتى حلول ميعاد تطبيق

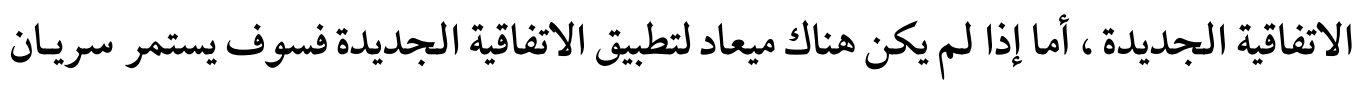
الاتفاقية الجماعية السابق لمدة عام واحد وذلك بعد انقضاء مهلة الإشعار البالغة ثلاثة شهور

(1) - المادة Y Y r T من قانون العمل .

(2)- cass.SOC. , Le 10 février 1999, n ${ }^{\circ}$ 96-40.851

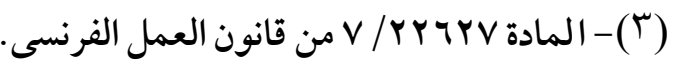

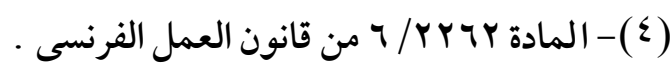




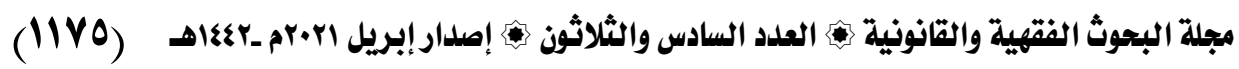
وهذا يعنى أنه سيظل تطبيق الأحكام الأكثر ملاءمـة للعامل في الاتفاقية الجماعية السابقة

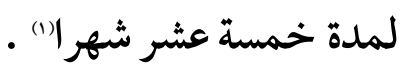

\section{الاستحواذ على الشركة}

أما في حالة ما إذا تم الاستحواذ على شركة صاحب العمل فإننا نكون أمام افتراضين :

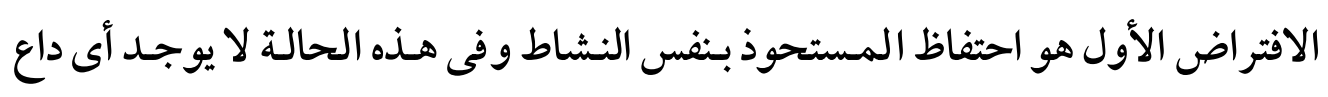
لإجراء تغيير على الاتفاقية الجماعية طالما أنهاصحيحة.

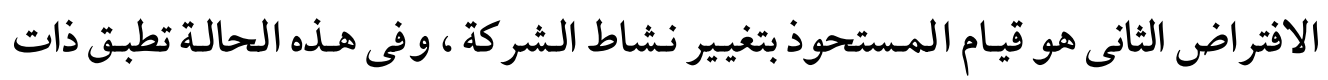

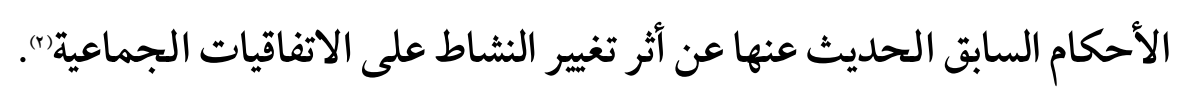

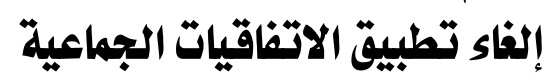
قد يحدث أن يطبق صاحب العمل اتفاقا جماعيا لا يتو افق مع نشاطه الرئيسى ، في هـذه

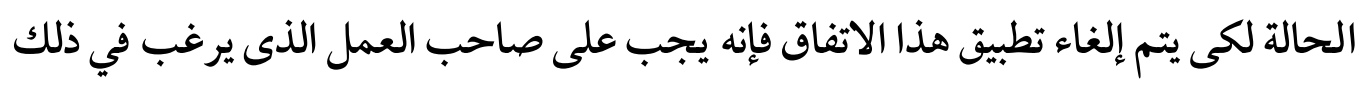

$$
\text { أن يبادر إلى إعلان نقض هذه الاتفاقية) . . }
$$

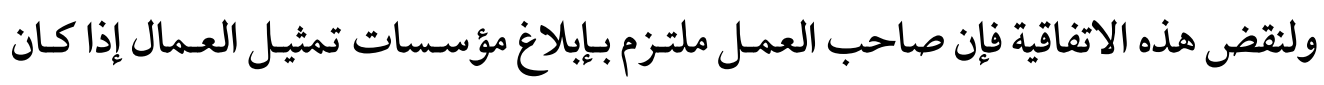
هناك قرار بإلغاء تطبيق الاتفاقية الجماعية مع تحديد الموعد النهائى لذلك . كما يلتزم كذلك بإبلاغ كل عامل على حدة ، ويمكن أن يتم استثناء هذا الإعلان الفردي إذإِ

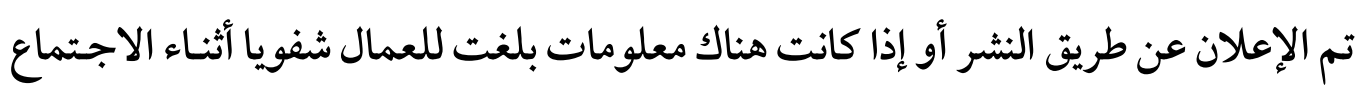
معهم أو عن طريق الإشارة البسيطة في قسيمة الر اتب .

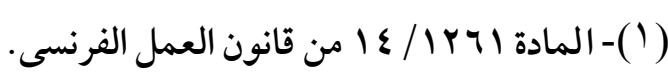

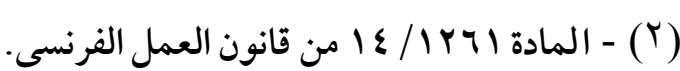

(3)- Cass. South Oil Company, 31 janvier 1996, N o 93-41.254 
(11V7)

في الممارسة العملية يتم إبلاغ العاملين عن طريق إرسال خطاب فردى مسجل مع مع إشعار

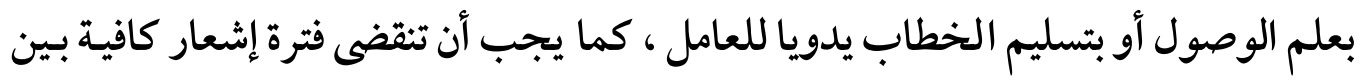

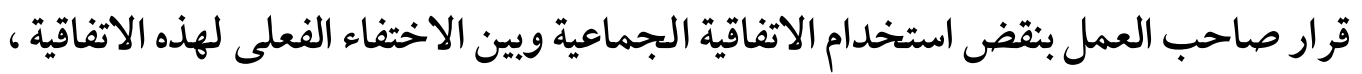

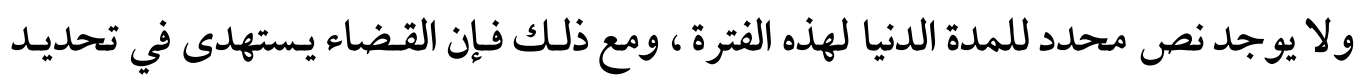
معقولية هذه الفترة بعدد المستفيدين من الاستحقاق وأهمية التغيير للعـاملين ومـدة التطبيق

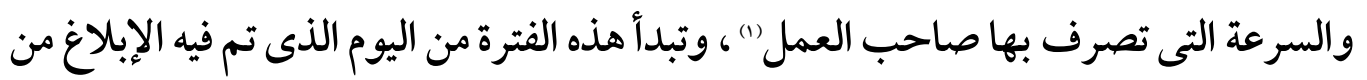

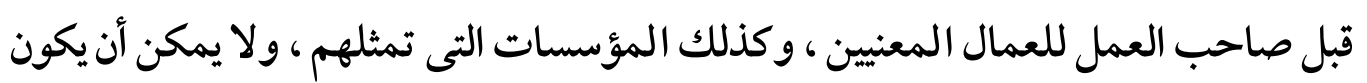

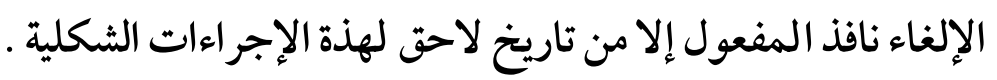

\section{7ــق العامل في المعرفة في حال بيع الشركة.}

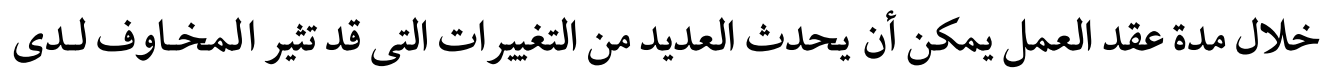
العاملين ، لا سيما فيما يتعلق بالعو اقب المتوقعة على عقد عملهم ، أحد هذه المخاوف هـو يحي

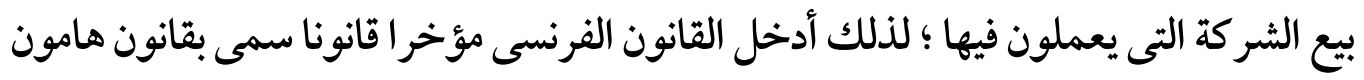

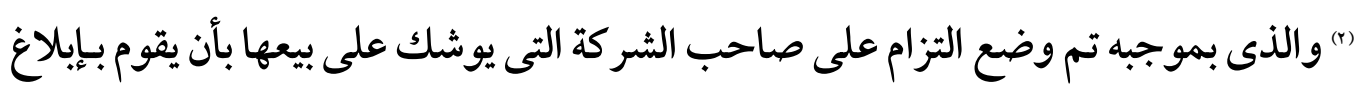

العاملين بهذا البيع ؛ حتى يقوموا بتقديم عرض للشر اء بدلا من من عملية البيع المخطط لها.

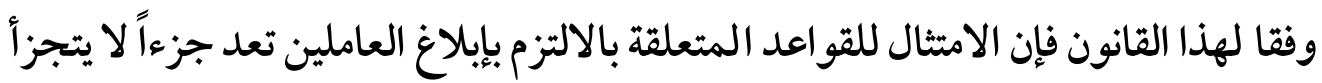
من الخطوات الإلزامية في نقل الأعمال ولا يمكن للممارسين لعملية البيع إهمالها بأى حال من الأحوال . - من الحطوات

(1)- CASS. SOC, 22 décembre 1988, $\mathrm{n}^{\circ}$ 86-42715 - CASS SOC, 24 octobre $1997, \mathrm{n}^{\circ}$ 96-40927.

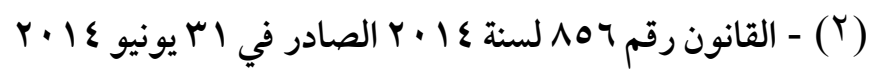




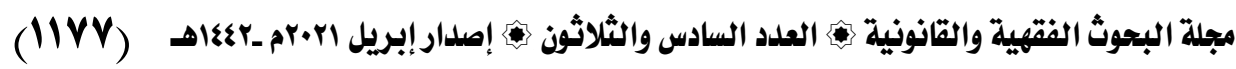

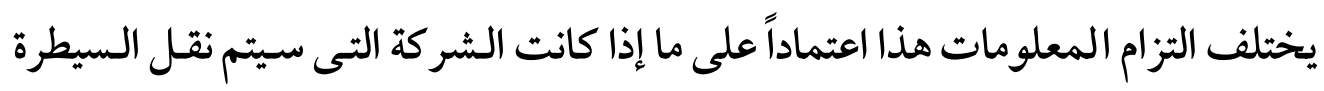
عليها توظف أقل أو أكثر من خمسين عاملالا" .

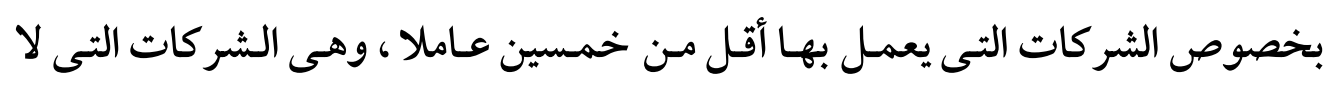
يشترط أن يكون لها مجلس عمل ، فإن إبلاغ العاملين يجب أن يتم قبل شهـرين على الأقل

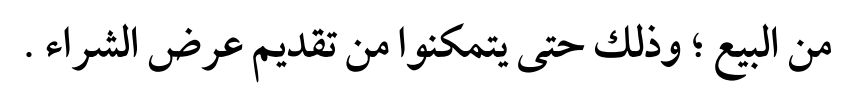

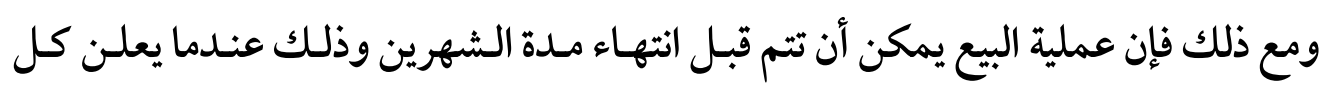
العاملين عن قرارهم بعدم تقديم عرض شراء (ب).

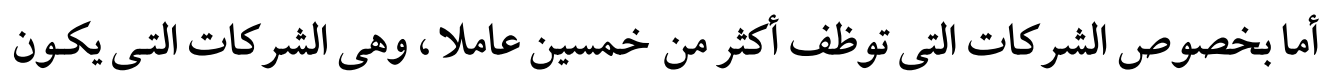

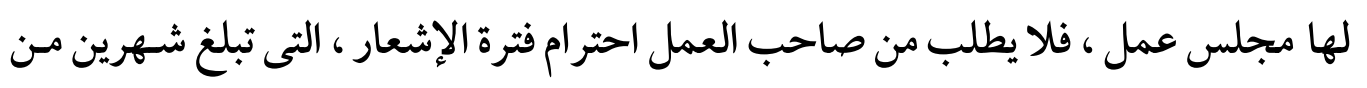
تاريخ إبلاغ العامل كما في الحالة السابق ، قبل إتمام عملية البيع وإنما يجب تنفيذ الالتزام بالمعلومات للعامل على أبعد تقدير في نفس الوقت الذى يقوم فيه صاحب الشاري الشر كة بإحالة مشروع البيع إلى مجلس العمل (r).

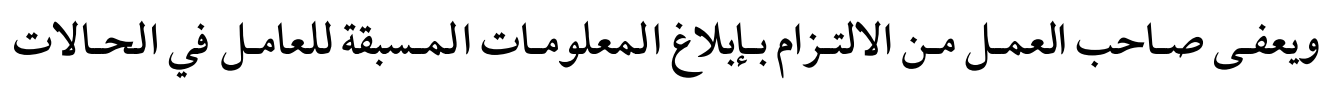
الأثية)(s)

الحالة الأولى: إذا كان البيع للزوج أو الأصل أو الفرع.

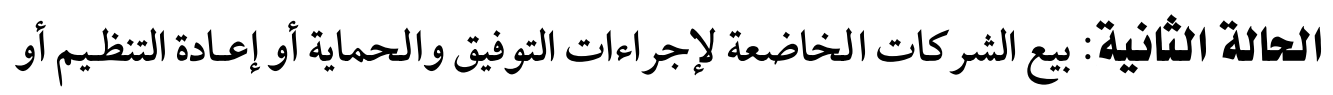
التصفية .

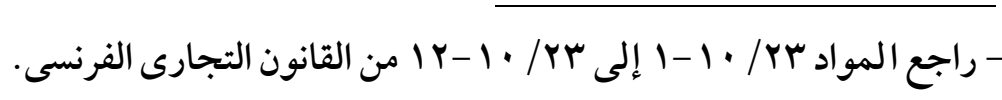

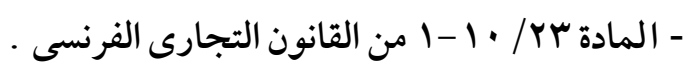

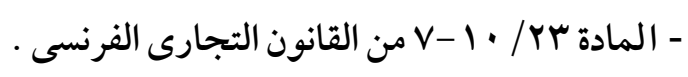

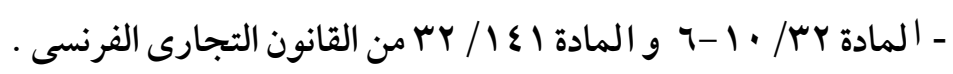


(l1YA)

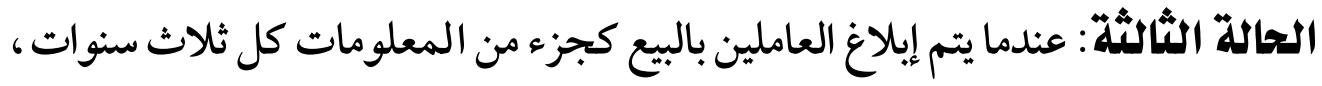

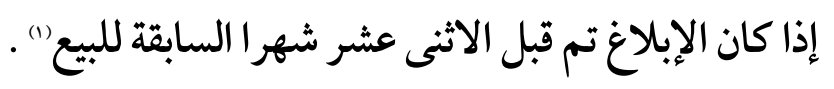

بخصوص المعلومات التى سيتم إبـلاغ العـاملين بها ، فهى معلومـات محـدودة للغايـة ،

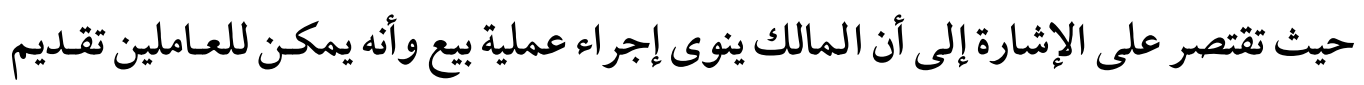

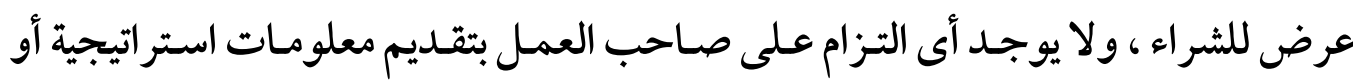
محاسبية أو مالية عن الشركة أو تقديم معلومات عن هويية المشترى أو سعر المعاملة .

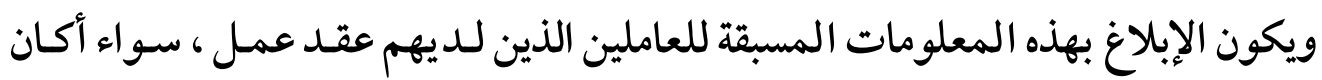

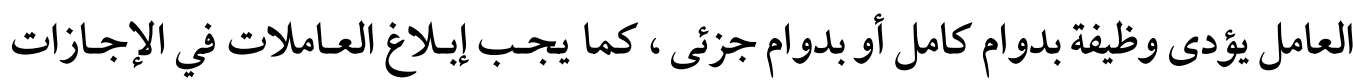

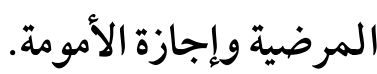

ويتم الإبلاغ من المالك إذا كان هو المشغل ، أما إذا كان المالك غير المشغل فإنه يبلغ المهان

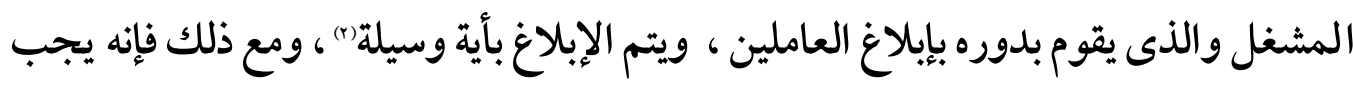

(1) - وفقا للمادة 1 1 من قانون هامون فقد تم إعداد نظام معلومات للعمال حول احتمالات استيلاء

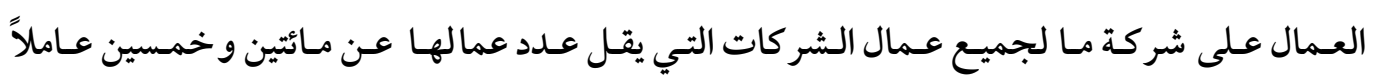
الخاضعين للكتاب الثاني من القانون التجاري.

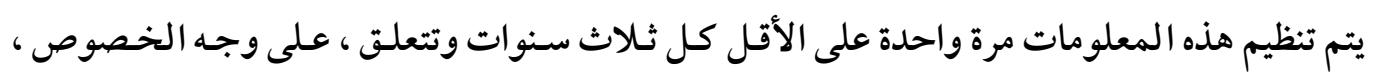

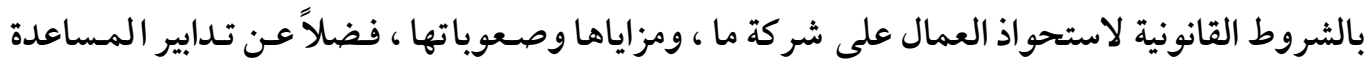
التي يمكنهم الاستفادة منها. تغطي المعلومات أيضًا الإرشادات العامة للشركة فيما يتعلق بامتلاك رأس مالها ، والها ، ولا سيما سياق

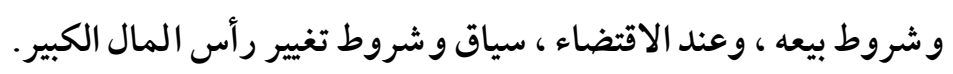

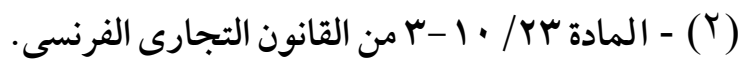




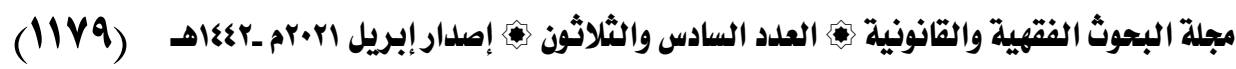

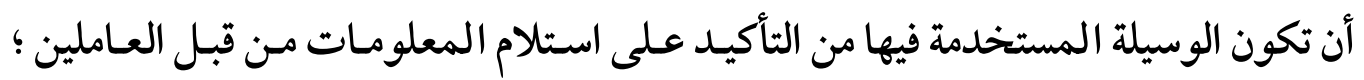

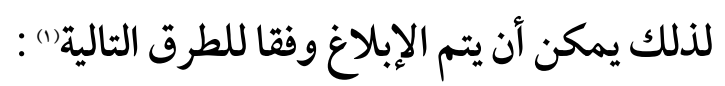

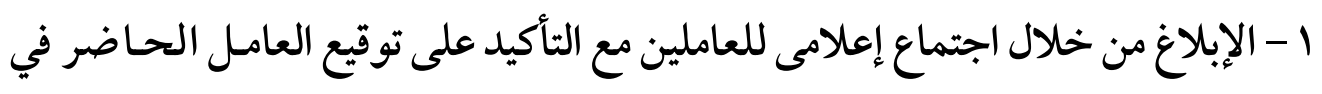

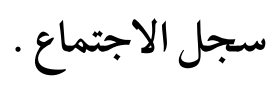
r - عن طريق شاشة ، حيث إن تاريخ استلام المعلومـات هـ الــى يـتم إلصاقه مـن قبل العامل في سجل مصحوب بتوقيعه يشهد على علمه بهذا الإرسال.

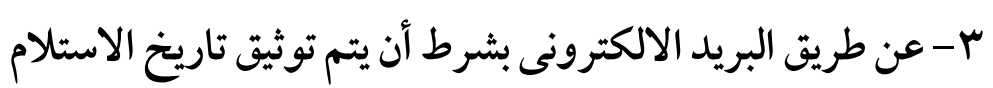

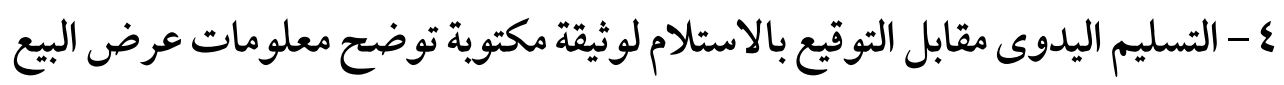
0 - بخطاب مسجل بعلم الوصول 1 - بفعل خارج نطاق القضاء أو بأية وسيلة يحتمل من خلالها لها التأكد من تاريخ الاستلام. عقوبة نقص المعلومات في الأصل كانت عقوبة عدم وجود معلومات مسبقة للعاملين هى بطلان عقد البيع ، إلا أن

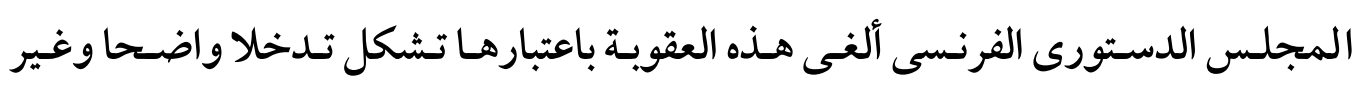
متناسبة) (r) بعد ذلك تم استبدال عقوبة البطلان بالتعويض المدنى ، فأصبح يحق للعامل رفع دعوى المئ

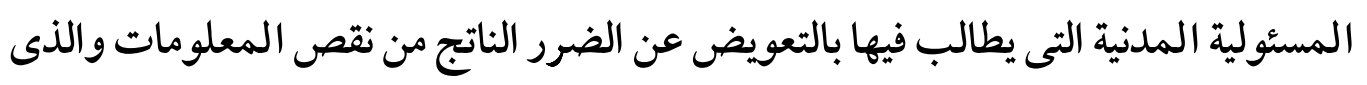

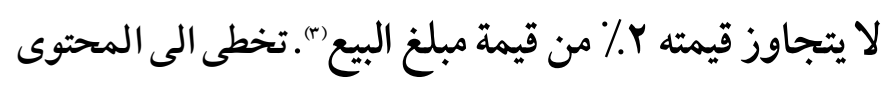

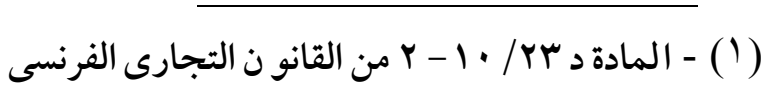

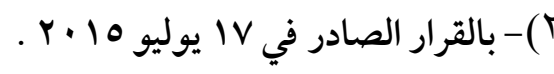

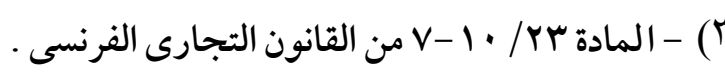


إذا قدم عاملا أو أكثر عرضا للشر اء فإن صاحب العمل له الحرية في قبول التفاوض معهم من عدمه ، ولا يوجد أى إلزام عليه بقبول عرض العامل ؛ لذلك يمكن القول بأن هذا الالتزام

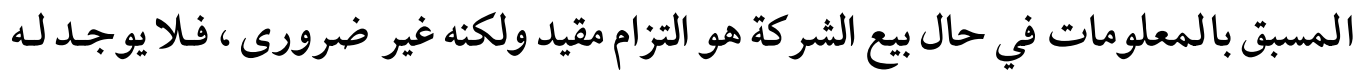

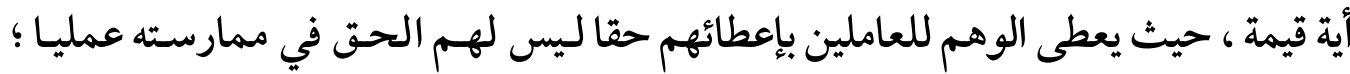
لذلك فهو تشريع عديم الفائدة.

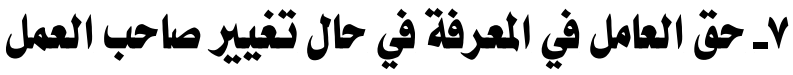

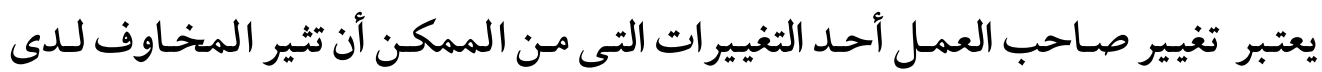

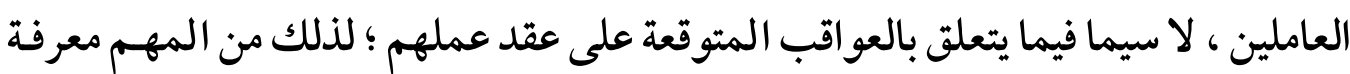
حقوق العامل عند حدوث تغيير صاحب العمل .

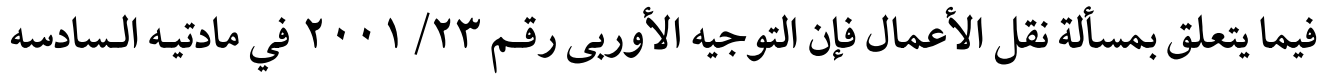

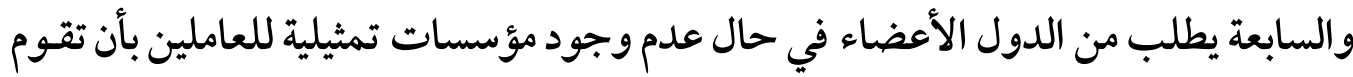
الشركة بتوفير معلومات مسبقة للعاملين المعينين عى تـاريخ نقـل الأعمال وسببه وعو اقبـه القانونية والاقتصادية والاجتماعية ، وعن التدابير المتوخاة فيما يتعلق بالعمال").

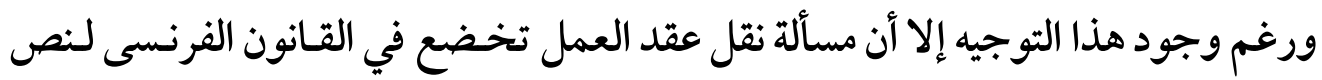

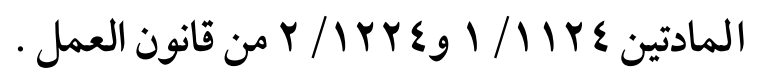

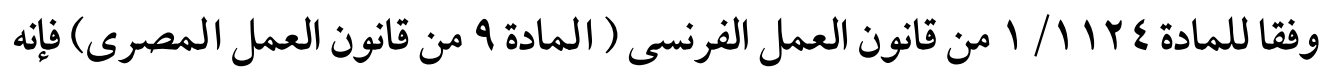
عند حدوث تغيير في الوضع القانونى لصاحب العمل ، ولا سيما عن طريق الميراث أو البيع

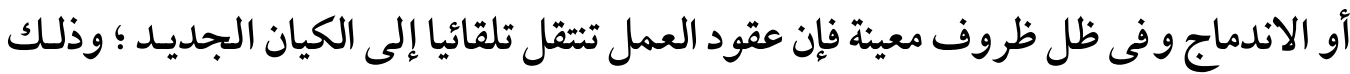
بهدف ضمان استمر ارية الأعمال.

(1)- A.Lepage ,op,cit,p.149 - Panagiota Perraki,op,cit,p.319 


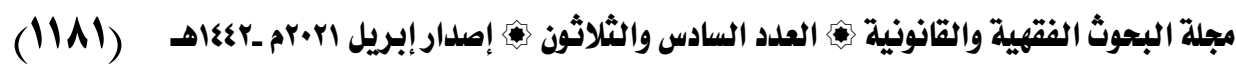
ويحدث هذا النقل التلقائى لجميع أنواع العقود : محدد المدة أو غير محدد المدة ، بدوام كامل أو بدوام جزئى ، عقد تدريب مهنى أو عقد تلمذه أو أى نوع آخر من عقود العمل . ويطبق مبدأ النقل حتى لو كان العامل في فترة الاختبار ، أو إذا كان عقد العمل معلقاً وقـت تغيير صاحب العمل سواء أكان العامل في إجازة تعليم الأولاد أو إجـازة أمومـة أو في إجـازة مرضية ، فقى كل هذه الأحو ال يسفيد العامل من حقه في الاحتفاظ بعقد عمله. لذلك فإن نقل العاملين يتم بشكل تلقائى وبدون إجر اءات رسمية ، ولا يمكـن للعامـل أن يعارض هذا النقل إلا في الحالة التى يستلزم فيها النقل تعديلات يرفضهاها")

\section{هل يترتب على ثقل عقد العمل تعليله إلهي}

من حيث المبدأ لا يترتب على نقل عقد العمل تعديله ، ويمكن للعامل رفض تعديل عقـد عمله إذا كان يخضصع لتعديلات جوهرية ، ومع ذلك يمكـن أن تـتم تغيير ات في عقـد العمل بالاتفاق المتبادل بين العامل و صاحب العمل الجديد ، وفى هذه الحالة من الضرورى إجراء

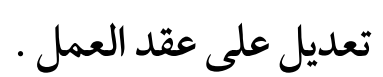

أمـا بـخـصوص إحـداث تغيسير في ظـروف العمـل فإنهـا مـن التعـديلات المـصرح بهـا

والمنصوص عليها باعتبارها تعديلات غير جوهرية ، و التى يمكن أن يؤدى رفض العامل لها إلى اعتباره سوء سلوك جسيم يستوجب الفصل .

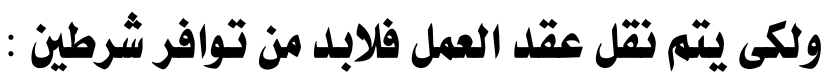
الشرط الأول : أن يكون الاحتفاظ بعقود العمل في وجـود نقل كيـان اقتصادى مستقل قادراً على العمل كمشروع كامل يسمح بممارسة نشاط اقتصادى يؤدى إلى مصالح خاصة ، بغض النظر عما إذا كان النشاط المنقول رئيسياً أم ثانوياً (r) .

(1)- CASS . SOC 1 juin 2016 no 21114314 - CASS SOC 17 avril $2019 \mathrm{~N}$ - 17-17880

(2) - CASS. Soc, 19 févr. 1981, n 79-42.484. 
(llar)

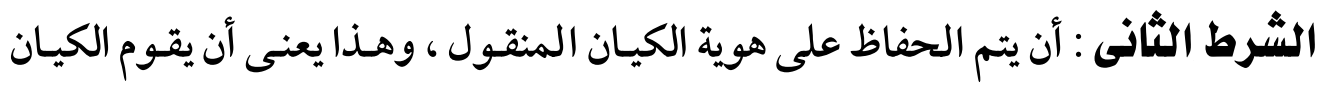

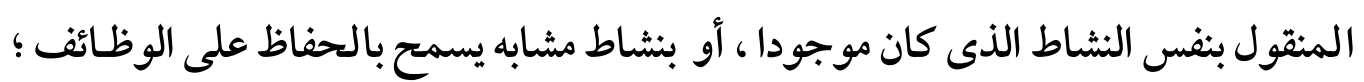
لذلك يجب لأن يستمر النشاط مع صاحب العمل الجديد بنفس الوسائل ل.

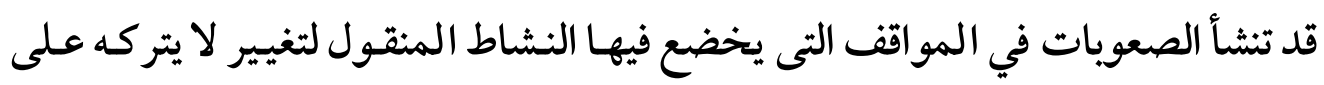

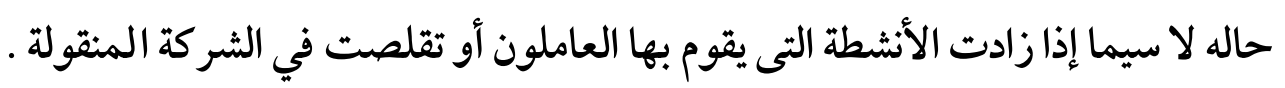

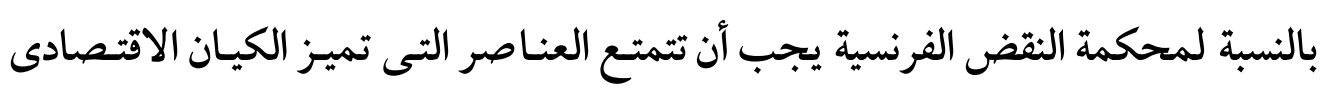

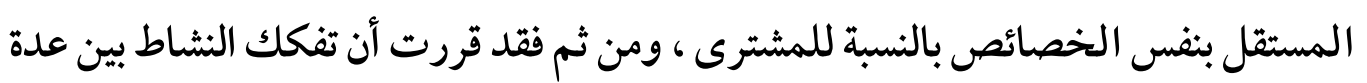

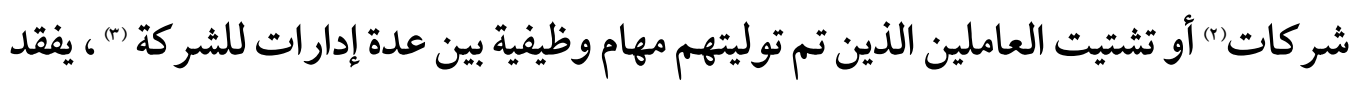

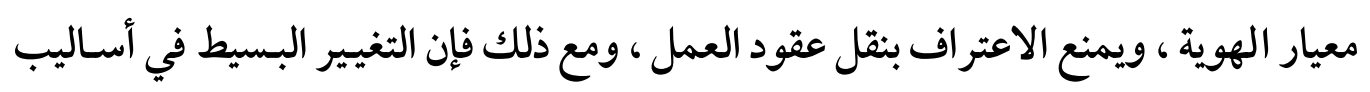

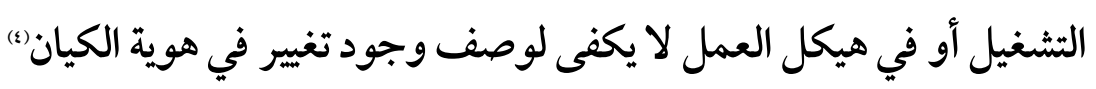

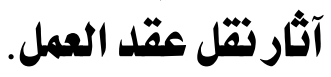

وفقا للمادة ؟ ؟ Y / / ا من قانون العمل الفرنسى( المادة 9 عمل مصرى) فإنه في حالة نقل

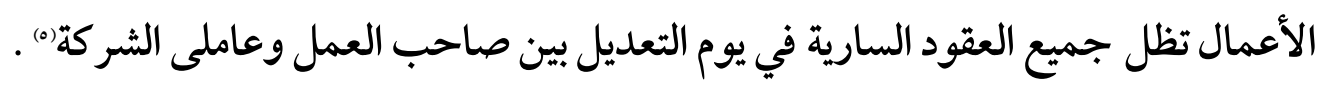

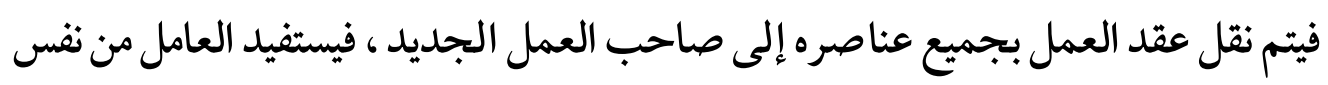

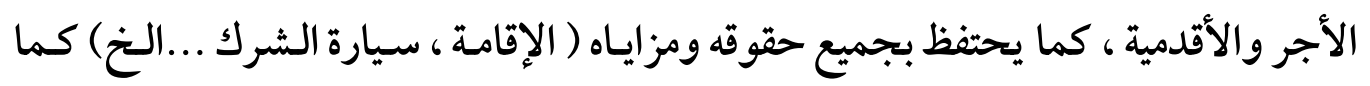

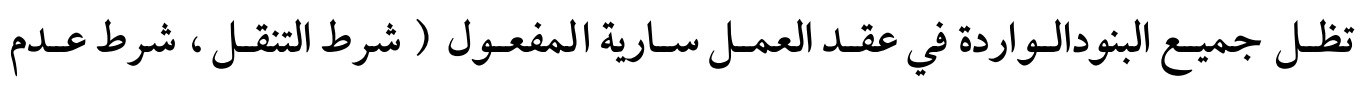

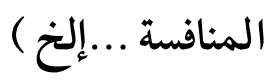

(1)- CASS. Soc, 12 oct. 1999, $\mathrm{n}^{\circ}$ 97-42.850.

(2) Cass, soc, 28 mai 2003, $\mathrm{n}^{\circ} 02-41.999$.

(3)- Cass. Soc, 12 déc., 1990, n 87-45.251.

(4)- Cass, soc, 12 oct. 2004, n 02-44.309.

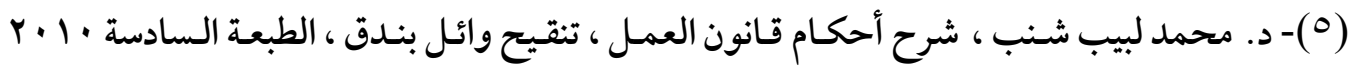

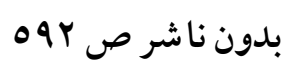




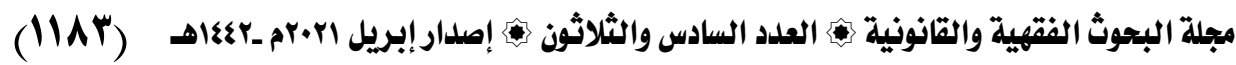

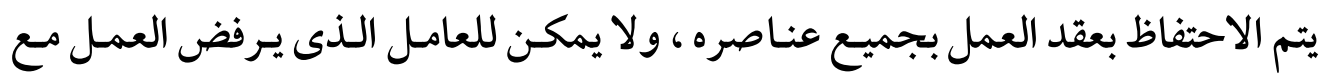

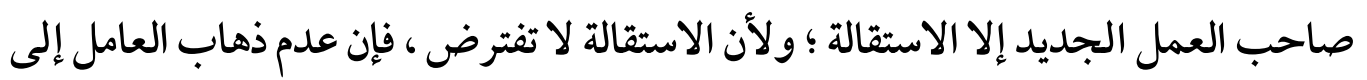

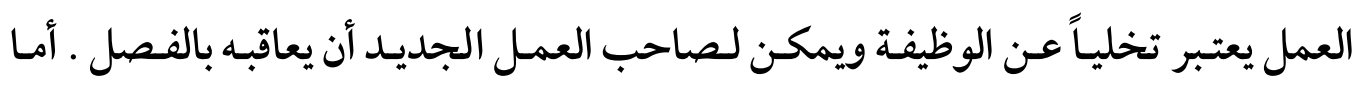
بخصوص ممثلى العاملين فإنهم يحتفظون بنفس الولاية .

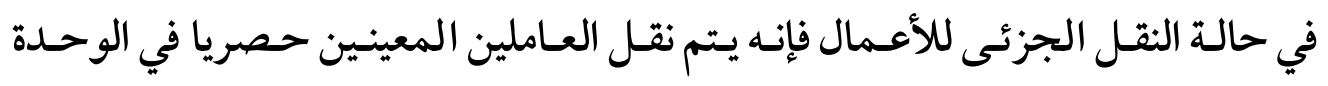

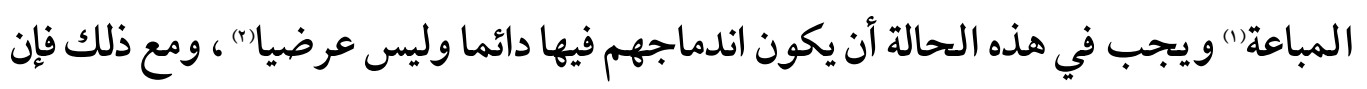
محكمة النقض الفرنسية أقرت قابلية عقد العمل للتجزئة ، وهذا معناه حدوث النقل الجزئى

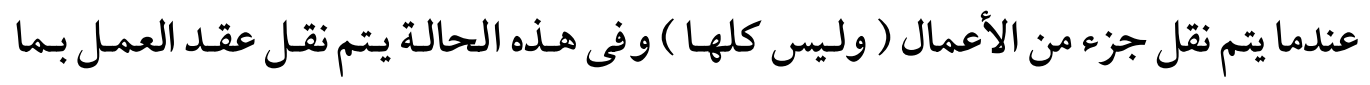
يتناسب مع الجزء المنقول إلى صاحب العمل الجديد ، فيتم الحفاظ على عقد عمل العامل

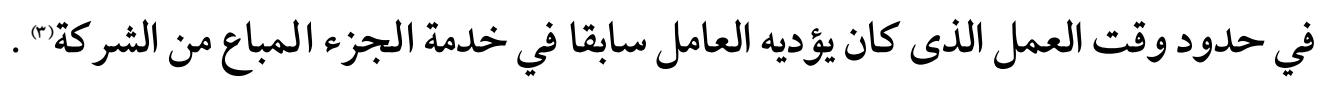

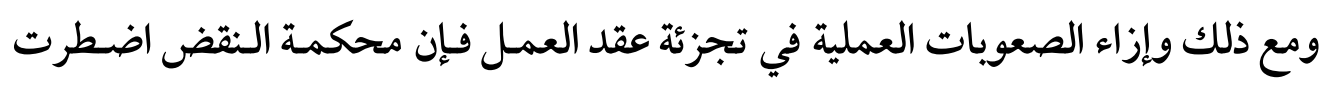

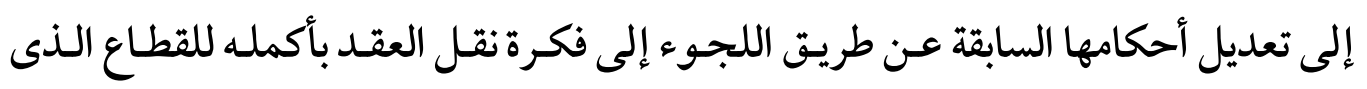
يستحوذ على معظم نشاط العامل (s).

\section{Aمعرفة العامل عن وسائل المراقبة.}

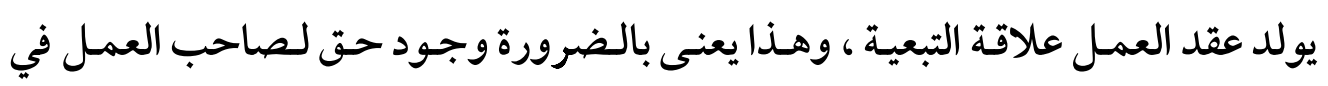
السيطرة على أداء المهام الموكلة إلى العامل.

(1)- Cass. Soc, 17 mars 1988, ${ }^{\circ} 85-45.444$.

(2)- Cass. Soc, 24 juin 2009, $\mathrm{n}^{\circ}$ 07-45.245.

(3)- Cass. Soc, 2 mai $2001\left(n^{\circ} 99-41.960\right)$ - Cass. Soc, 8 juillet $2009\left(\mathrm{n}^{\circ}\right.$ 08-44.396.)

(4)- Cass. Soc,30 mars 2010 ( $\mathrm{n}^{\circ} 08-44.227$ et 08.42 .065$)$. 


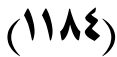

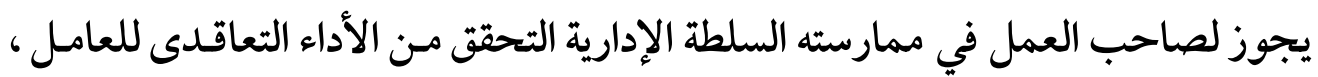

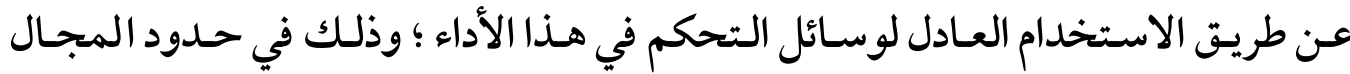

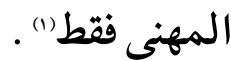

صاحب العمل له الحق في مر اقبة نشاط عماله في أوقات العمل ل() بما له من سـلطة الرقابة والإشر اف عليهم خلال فترة العمل "(r) .

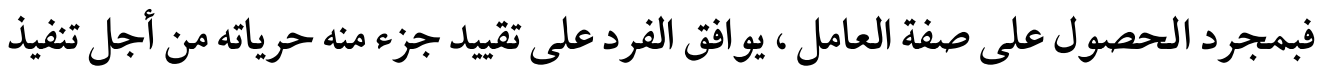
التزاماته المهنية. يجب أن ينفق جزء من وقته في العمل وخلال هذه الفترة ، يُطلب منه أداء واجباته بموجب سيطرة وسلطة صاحب العمل . هذا هو جوهر عقد العمل . و صاحب العمل هو قبل كل شيء صاحب عمل لديه مصلحة في توجيه النشاط الذي يقوم به الشركة ، و أيضًا

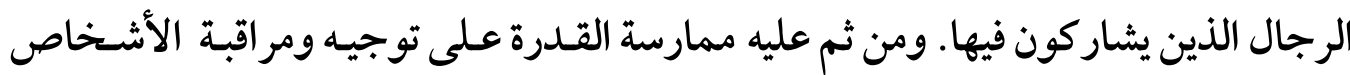
الذين يعملون لديه ، من أجل التأكد من أنهم يؤدون مهامهم بشكل صحيح ونه وأن عمله مربح (s) .

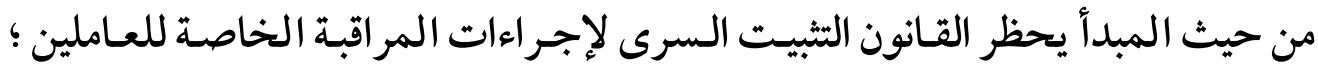
ولكى يقوم صاحب العمل بمر اقبة عادلة فإنه يجب أن يفى مسبقا بالتز امه بـإبلاغ العـاملين ،

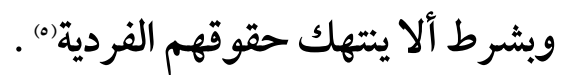

وإذا كـان مـن الجـائز لصاحب العملـل مر اقبـة نشاط العامل كجـزء مـن سـلطته الإداريـة والتظيمية ، إلا أنه يوجد حالات معينة و محددة يجب فيها على صاحب العمل مر اقبة نشاط

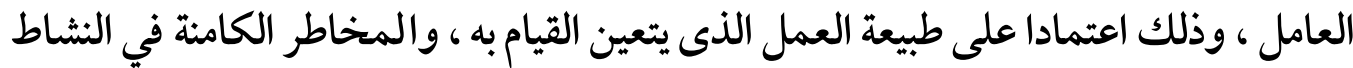

(1)-Madame Alice MANNES, LA CONSCIENCE EN DROIT SOCIAL, THĖSE , UNIVERSITÉ PANTHÉON-ASSAS (PARIS II) 2018 ,p.257

(2)- Assemblée générale du 14 mars 2000, appel n ${ }^{\circ}$ 98-42.090, Bull. N101

(3)- Assemblée générale du 4 juillet 2012, appel n ${ }^{\circ}$ 11-30.266, Bull.

(4) - Panagiota Perraki, op , cit,.p. 10

(5)- Léa Amic, op, cit , p.497 Objet 736 


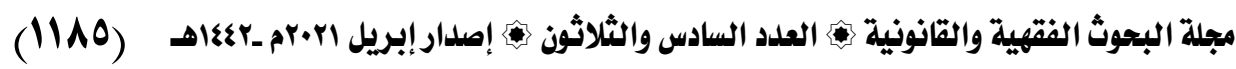
، و فى هذه الحالة سيخضع العامل لمر اقبة تعرضه للخطر ( مثل المر اقبة الإشعاعية ) وذلك كجزء من واجبه في المنع ، حيث يطلب من صاحب العمل القيام بذلك واتخـاذ قرار بـشأن تـدابير المراقبـة التى تهـدف إلى السماح بالتـدخل السريع مـن قبل خـدمات الطـوارئ في الحالات الطارئة لأداء بعض الأعمال التى تنطوى على مخاطر خاصة وخطيرة') . المر اقبة إذن هى أحد الإجر اءات الأمنية التى يجب تحديدها وتنفيذها) . ما يهمنا في هذه الدراسة هو معرفة أحوال المراقبة المصرح بها ، ومـدى حـق العامل في العلم المسبق بوجود هذه المراقبة ، وأثر الدليل الناتج عن هذه المر اقبة كوسيلة للإثبات أمام جهات القضاء. من حيث المبدأ فإن المر اقبة البسيطة في مكان العمل مـن قبـل صـاحب العمل لا تتطلب إعلام مسبق للعامل (r) ، ولا تشكل في حد ذاتها طريقة إثبات غير قانونية ()، ومع ذلك يمكن أن تنشأ المشاكل عند الحصول على تقنيات معينة من أجل التحكم في نشاط العاملين · لتطبيق هذا النوع من المراقبة فإن صاحب العمل يلتزم بعدد معين من الالتزامات :

هذه الصناعات بصناعات التدفق ، بما في ذلك الصناعة الكيميائية والصناعة النوويـة التى تعتبر النمـوذج الأصلى لها، وهـذه الصناعات تتطلب أن يكون النشاط مر اقب باستمر ار للتحكمم في

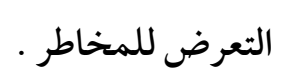

Lucie Jubert, L'organisation du travail et la prévention des risques .professionnels, l’Université Paris Nanterre , 2019 ,p.27 Objet 369 (Y) - من قبيل ذلك نظام البصمات لمنطقة معينة في داخل منشأة نوويـة ، بهـدف تـوفير الحمايـة لهذه.

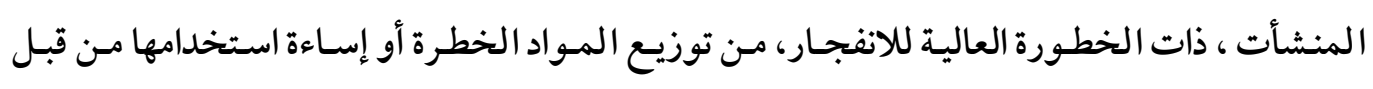
أطر اف غير مصرح لهم باستخدامها .

(3)- Madame Alice MANNES,op,cit, p. 258

(4)- Cass. soc., 26 avril 2006, $\mathrm{n}^{\circ}$ 04-43.582, Bull. civ. V, $\mathrm{n}^{\circ} 145$ 
$(1117)$

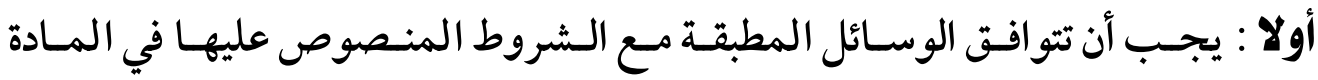

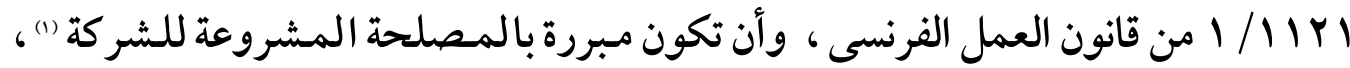

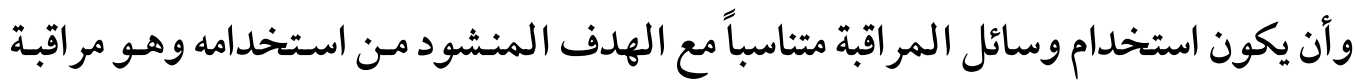
نشاط العامل المهنى فقط (") دون انتهاك لخصوصياته وحرياته الشخصية").

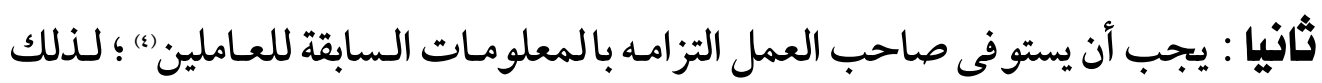

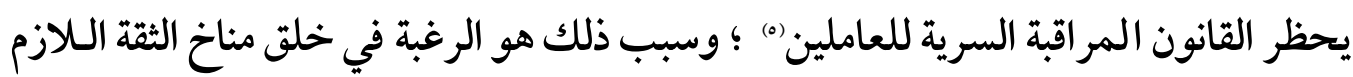

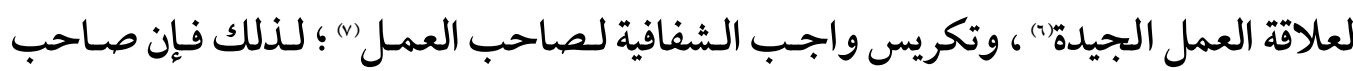

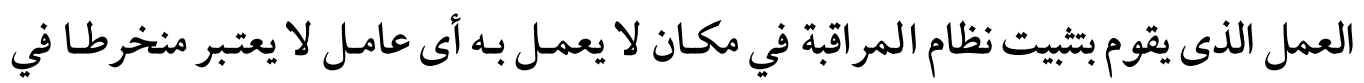

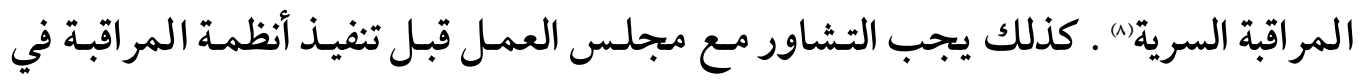

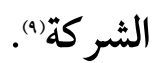

(1)- Cass. soc., 3 avril 2001, n 98-45.818, Bull. civ. V, $\mathrm{n}^{\circ} 115$

(2) - Délibération n ${ }^{\circ} 2009-201$ du 16 avril 2009 de la CNIL

(3) - Madame Alice MANNES,op,cit, p.257- Grand Robe, 12 janvier $2016, \mathrm{n}^{\circ} 61496 / 08$

(4)- Panagiota Perraki,op,cit,p.265 - cass.Soc. 10 janv. 2012, nº 10-23482, Bull. civ. V, n 2 ; RDT 2012, p. 223, obs. A. GARDIN ; JCP S 2012 (0) - المراقبة السرية ينبغي السماح بها فقط بما يتوافق مع الضمانات التي ينص عليها التشريع الوطني

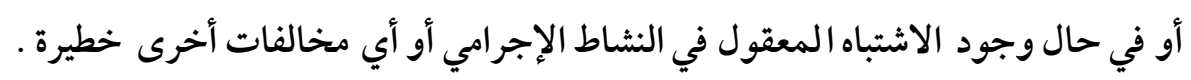

Panagiota Perraki, op , cit,.p.10

(6) - Léa Amic, op, cit , p.498 Objet 737

(7)- Ibid

(8)- Assemblée générale, 31 janvier 2001, appel No. . une 98-44.290 , le taureau. $2001, \mathrm{~V}, \mathrm{n}$ a 28

(9)- cass. Soc , 15 mai 2001 , Appel No. . une 99-42.219, le taureau. 2001 , V, n a 167- Soc., 7 juin 2006, pourvoi $\mathrm{n}^{\circ}$ 04-43.866, Taureau. 2006, V, $\mathrm{n}^{\circ} 206$. 


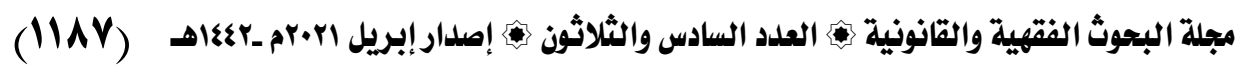
بخصوص نظام المر اقبة بالفيـديو فلابـد أن تكـون موضـوع معلومـات للعامـل ، وضرورة استشارة مجلس الأعمال"(1) ، وفى حال مخالفة ذلك فإنها تعتبر غير قانونية ولا يؤخذ بالدليل

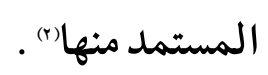
أما بخصوص استخدام وسيلة المر اقبة بالفيديو التى يقصد منها ضمان أمان الشر كة ، ولم يكن الاستخدام للتحكم في العامل في أداء واجباته ،فإنه يؤخــذ بالـدليل المـستمد مـن هـذه المر اقبة(r) ، وقد قضى بأن العامل لا يستطيع التمسك بـشروط تطبيت وسـائل وتقنيـات مراقبـة نشاط العامل في المتجر ؛ وذلك لأن عدم عدالة الدليل تعنى غموض المناورات من صاحب العمل بقصد القبض على العامل المخطئ دون علمه(s) ، و فى هذه الحالة فإن صاحب العمل لم يقم بأية مناورات ( كإرسال رسائل مفخخة دون علم العاملين بقصد اصطيادهم )(ه) أثناء قيامه بتر كيب وسائل المراقبة التى تستهدف أمان المتجر. فيما يتعلق بتسجيلات المحادثات الهاتفية ، فإن التسجيلات السرية تعتبر وسيلة غير عادلة وغير مشروعة في الإثبات()؛ لذلك فـإن تسجيل المحادثات الهاتفيـة مهـما كانـت دوافعـه ، سواء أكان تسجيلاً للصور أو الصوت دون علم العامل يشكل وسيلة إثبات غير قانونية (v).

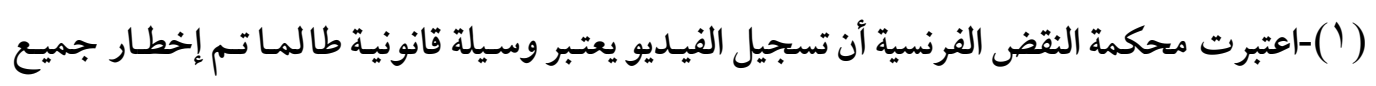
عمال مصنع الجعة والبار الخاص بالكازينو بوجود كاميرات مر اقبة تعمل في الدوام . Cass.Soc. 2 févr. 2011, n 10-14263

(2) - Madame Alice MANNES,op,cit, p.258 - Soc. 7 juin 2006, $\mathrm{n}^{\circ}$ 04-43866- Cass. soc., 5 novembre 2014, $\mathrm{n}^{\circ} 13-18.427$, Bull. civ. V, $\mathrm{n}^{\circ}$ 255 ; RJS $1 / 15 \mathrm{n}^{\circ} 2$.

(3) - cass. Soc., 19 avril 2005, pourvoi $\mathrm{n}^{\circ}$ 02-46.295, Taureau. 2005, V, $\mathrm{n}^{\circ} 141$

(4)- Soc. 26 juin $2013, \mathrm{n}^{\circ} 12-16564$

(5)- Soc., 10 décembre 1997,pourvoi no 95-42.661, Taureau. 1997, V, no434

(6)- Soc. 29 janv. 2008, no 06-45814

(7)- Soc., 20 novembre 1991, pourvoi no 88-43.120, Taureau. 1991, V, no 519 
$(11 \mathrm{AA})$

وعدم مشروعية الدليل تنشأ من السرية ، وليس مس انتهاك الخصوصية ؛ لـذلك فإنه يتم

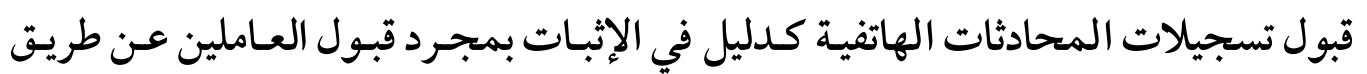

إبلاغهم المسبق من قبل صاحب العمل ، وبذلك يصبح التصنت وسيلة صالحة للإثبات")

وينطبق نفس الحكم على مراقبة الرسائل القصيرة (SMS) إذا تم تسجيلها بواسطة جهاز

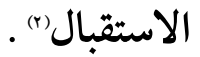

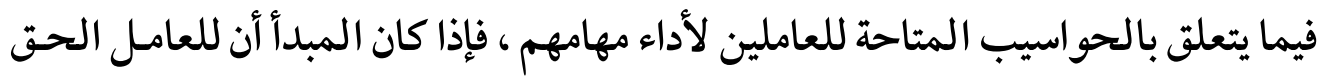

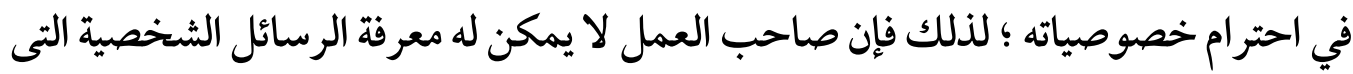

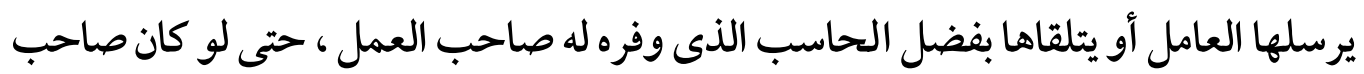
العمل يحظر الاستخدام غير المهنى (r).

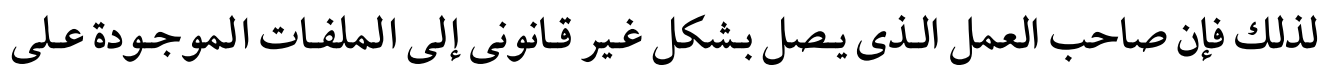

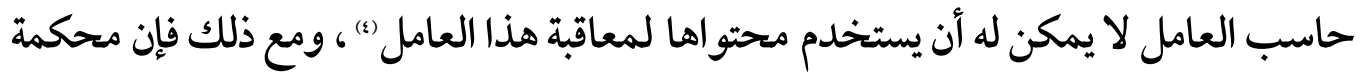
النضض الفرنسية خففت من حدة هذا الأمر بعض الشئ حيث اعتبرت أن الملفات التى ينشئها العامل باستخدام أداة تكنولوجيا المعلومات التى يتيحها له صاحب العمل يفترض حست أنها لأداء

(1)- Soc. 14 mars 2000, no 98-42090, Bull. civ. V, no 101, D. 2000. IR 105.

(2)- Soc. 23 mai 2007, no 06-43209, Bull. civ. V, no 85 ; RDT 2007, p. 530, obs. R. DE QUENAUDON- Soc. 6 févr. 2013, no 11-23738, D. 2013, p. 1775

(3)- Soc. 2 oct. 2001, JCP E 2001, 1918, note C. PUIGELIER ; Sem. soc. Lamy 15 oct. 2001, p. 8, note G. LYON-CAEN ; v. S. BRÉZIN et I. DE BENALCAZAR

(4)- Léa Amic, op, cit , p.503 Objet 743 


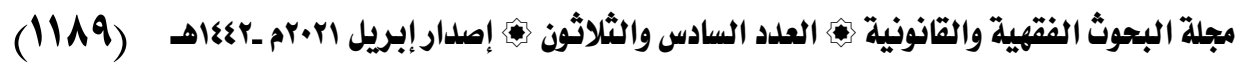

العمل وذات طبيعة مهنية ، بحيث يحق لصاحب العمل فتحها دون حضور العامل ، وذلك ما

$$
\text { لم يحدد العامل كونها "شخصية "(1). }
$$

كما اعتبرت أن ذكر كلمـة مستنداتى لا يعطى الملف طابع شخصى () أو مجـرد إلصاق الاسم الأول أو اللقب أو الأحرف الأولى على الملف (r). ويطبق نفس الأمـر بالنسبة للبريـد

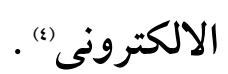

بخصوص العمل عن بعد فإن صاحب العمل يجب أن يحترم خصوصية العامل عن بعـد، وإذا كانت طريقة المر اقبة موجودةً فيجب عليه إبلاغ العامل بذلك ، وعلى أن تكون المر اقبـة متناسبةً مع الهدف منها ، وأن تتم وفقا لأحكام القانون ونمان. أما بخصوص الاتصالات عبر الانترنت التى يقيمهـا العامـل عـلى مواقـع الانترنـت خـلال وقت العمل ، وبفضل تكنولوجيا المعلومـات التى أتاحها لـه صـاحب العمل لأداء عمله ، فيفترض أن يكون لها طابع مهنى ، بحيث يحق لصاحب العمل البحث عنها من أجل التعرف

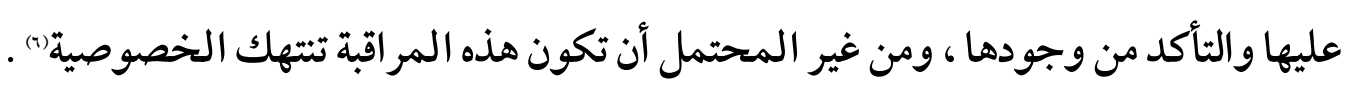
أما بخصوص مر اقبة الانترنت خارج ساعات العمل ، فإن صاحب العمل يجـب أن يتقـدم بطلـب إلى المـشغل (v) ، و استشـارة لجنة الشر كة ، وكـذلك الالتـزام بالمعلومـات الفرديـة

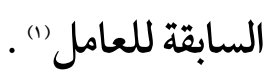

(1)- cass.Soc. 18 oct. 2006, no 04-48025, Bull. civ. V, no 308, p. 294 ; JCP S 2006, no 1946, note J.-Y. FROUIN - cass. Soc., 10 mai 2012, pourvoi no 11-13.884, Taureau. 2012, V, no 135

(2)- Soc. 10 mai 2012, no 11-13884, Bull. civ. V, no 135

(3)- Soc. 21 oct. 2009, no 07-43877, Bull. civ. V, no 226 ; Soc. 8 déc. 2009, no 08-44840, RJS 2010, no 144

(4)- Soc. 5 juil. $2011, \mathrm{n}^{\circ} 10-17284$

(5)-Panagiota Perraki, op , cit,.p.320

(6)-Soc. 9 juil. 2008, no 06-45800 ; Soc. 9 févr. 2010, no 08-45253- Soc., 12 février 2013,pourvoi no 11-28.649, Taureau. 2013, V, no34

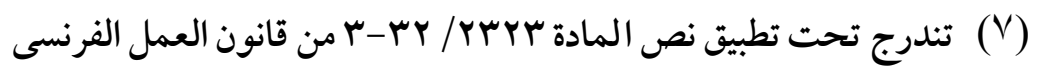


(119.)

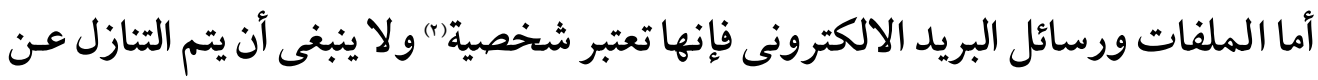

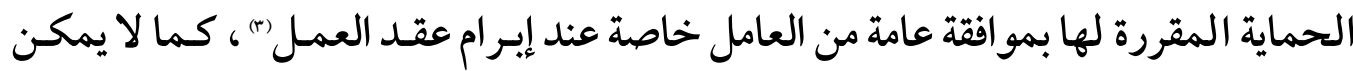

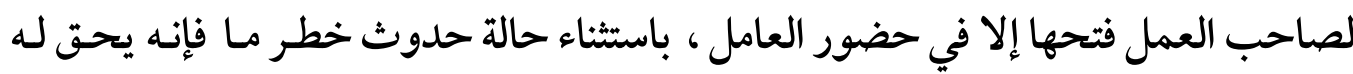
فتحها"(5)

أما بخصوص نظام تحديد الموقع الجغر افى لضمان التحكم في ساعات العمل ، فهو أمر

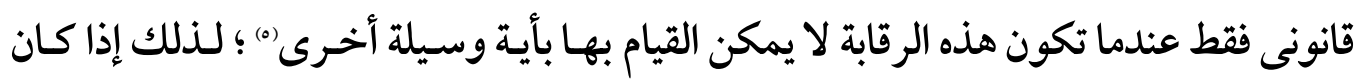

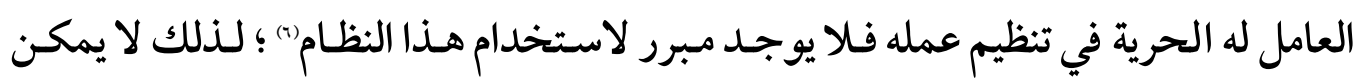

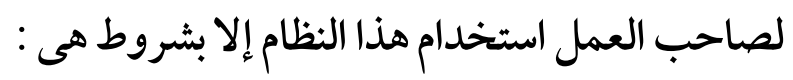
1-أن يكون هذا النظام للأغر اض المعلنة للجنة الوطنية لمعالجة البـة البيانات والحريات

(CINIL)

- (1)Soc. 15 mai 2001, no 99-42937, Bull. civ. V, no 168 ; RJS 7/2001, no 830

(Y) - بخصوص الرسائل العادية فإنه " إذا اطلع صـاحب العمـل على الرسالة الخاصة بأحـد العمال

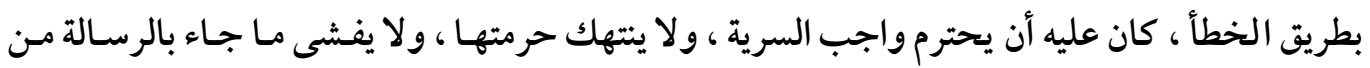

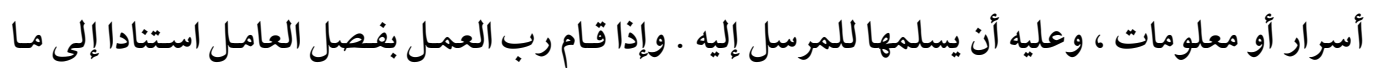

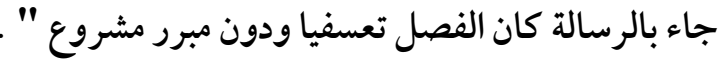

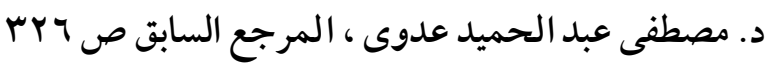

(3)-Panagiota Perraki,op,cit,p. 274

(4)- Léa Amic, op, cit , p.508 Objet 748

(0)-عاقبت محكمة النقض الفرنسية صاحب العمل الذى استخدم أداة تحديد الموقع الجغراقى بشكل

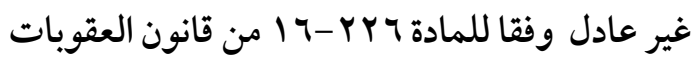

Cass. soc., 29 janvier 2008, nº 06-45.814, JSL 2008, 229-14 (6)-Léa Amic, op, cit , p.509 Objet 750 - Soc., 3 novembre 2011, pourvoi no 10-8.036, Taureau. 2011, V, no 247 


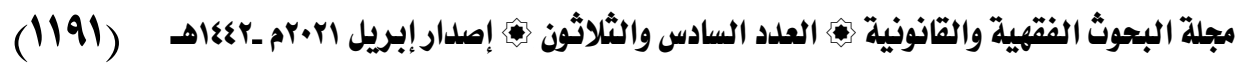
r -لفت انتباه العامل لاستخدام هذا النوع من المر اقبة").

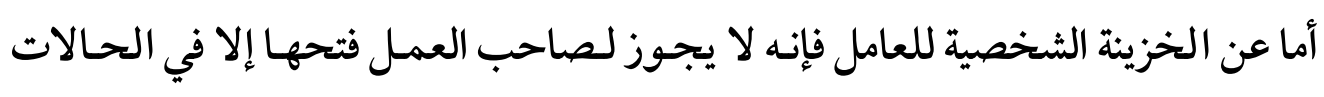
وبالثروط التى تحددها اللائحة الداخلية وبحضور العامل المعنى ، ويعتبر بند اللائحة غير قانوني إذا وفر لإدارة السلطة ، في أي وقت وبدون تـوفير معلومات مسبقة للعامل، لفتح غرف تغيير الملابس أو الخزائن الفردية الموجود بها ملابسه وأغراضه الشخصية). أما عن تفتيث حقيبة العامل الخاصة للتحقت من محتوياتها ، فلا يجحوز تفتيشها بـدون المعلومـات المـسبقة للعامـل ، أو مو افقته الـضرورية لـذلك وبـشرط تحـذيره مـن حقـه في معارضة هذا الأمر أو طلبه حضور شاهد اهّ) ومع ذلك يجحوز تفتيش هـذه الحقائب في ظل وجود ظروف استثنائية ، فيجوز لصاحب العمل تقييد الحريات الفردية والجماعية للعاملين(s)

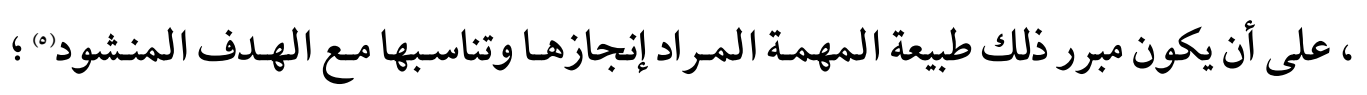

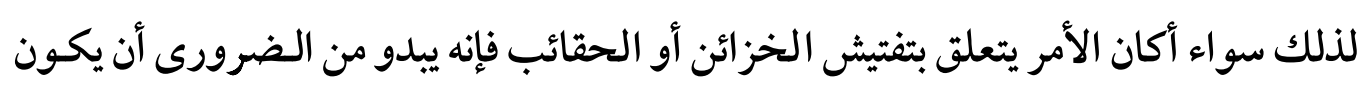

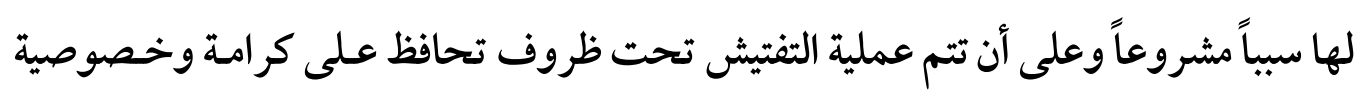
العامل (1) ؛ لذلك فإن الرقابة اليومية والممنهجة لحقائب العاملين يتجاوز القيود التى يمكن

(1)-Soc. 3 nov. 2011, no 10-18036, Bull. civ. V, no 247 ; JCP E 2012, no 1926 , note CORRIGNAN-CARSIN

(2) - Panagiota Perraki,op,cit,p.352-353

(3) - Ibid - Soc., 11 février 2009, pourvoi no 07-42.068, Taureau. 2009, V, no 40

(§)- يمكن لصاحب العمل بعد التشاور مع مجلس العمل أن يطلب فتح حقائب عماله من قبل حراس

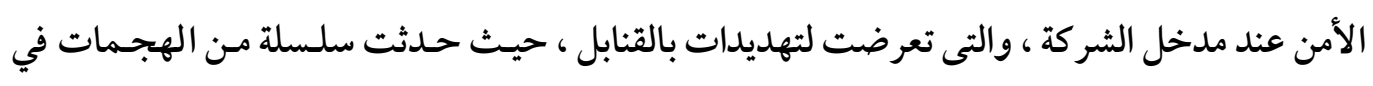

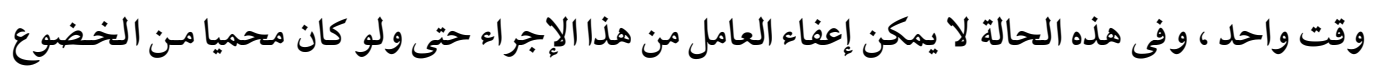
لهذا الإجر اء ، مبرر ذلك الظروف الاستثنائية ومتطلبات الأمن المتناسبة مع الهدف المنثود

Soc.3 avril 2001, pourvoi no 98-5.818, Taureau. 2001, V, no 115

(5) - Soc. 3 avril 2001, n 95-45818, Bull. 2001, V, no 115

(6) - Panagiota Perraki,op,cit,p.353 
(llar)

حق العامل في المعرفة في عقد العمل

لصاحب العمل فرضها قانونا على عماله ؛ من أجل ضمان الأمن داخل الثر كة بسبب الطبيعة العامة وغير المبررة').

\section{جعمرفة العامل عن مخاطر العمل .}

صاحب العمل هو الشخص الذى يطبق نهج الحماية في شر كته ، فهو مسئول عن صسحة

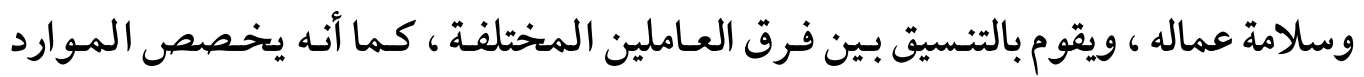
اللازمة للحفاظ على الصحة البدنية والعقلية لجميع عماله .

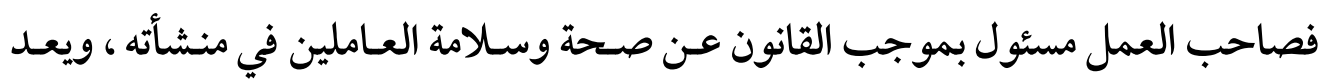

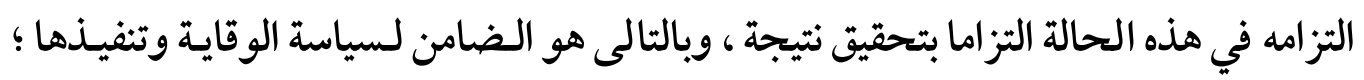

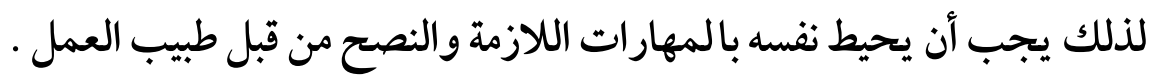

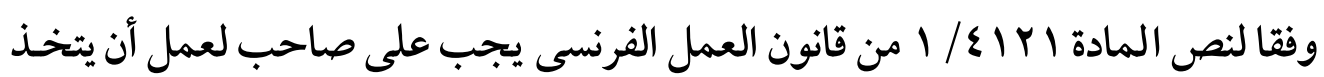

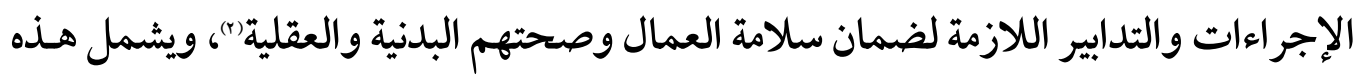

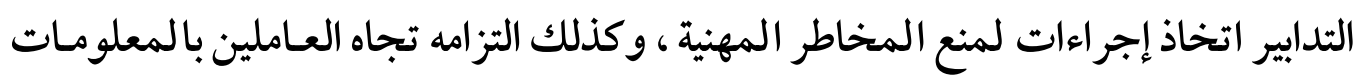
والإجر اءات التدريبية المتعلقة بهذه المخاطر (") .

(1) - Léa Amic, op, cit, p.513 Objet 755 - CA Rennes 6 févr. $2003 n^{\circ}$ $02-2859$

(2) - A.Lepage ,op,cit,p.155

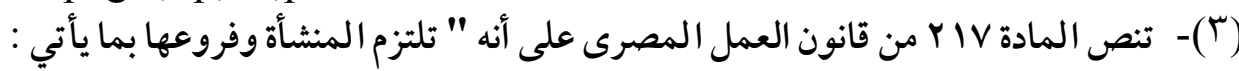

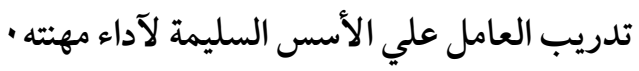

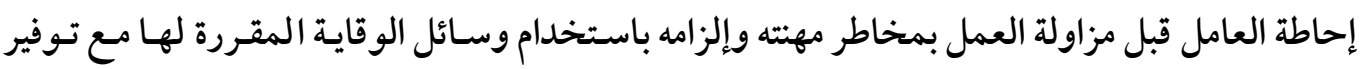

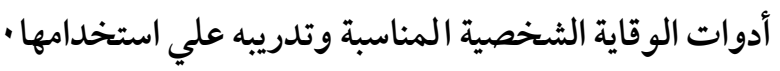

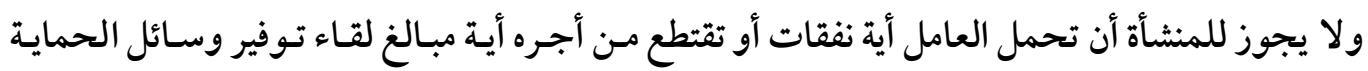

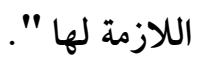




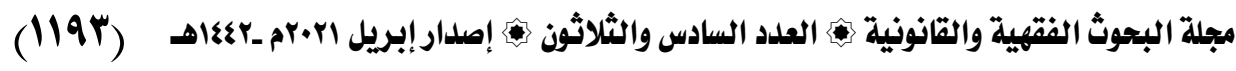
وفقا لنص المادة ر | | | | | من قانون العمل الفرنسى فإن صاحب العمل ملتزم بأن يدون في وثيقة واحدة نتائج تقييم المخاطر التى يقوم بها على صحة وسلامة العمال(1) ، مع مراعاة

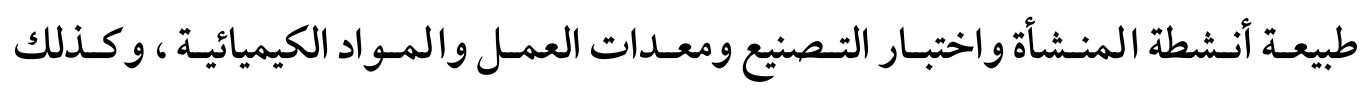
الاستعدادات في تجهيز أو إعادة تجهيز أمـاكن العمل أو التركيبـات وفى تعريـف محطات العمل ، كما يتضمن هذا التقييم جـردا للمخـاطر المحـددة في كل وحـدة عمـل بالشر كة أو المؤسسة ، بما في ذلك تلك المتعلقة بالبيئات الحرارية.

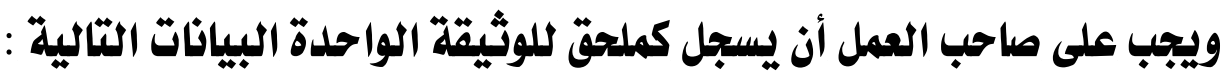

•البيانات الجماعية المفيدة لتقيم التعرض الفردى لعوامل الخطر التى مـن المحتمـل أن تسهل في الوقاية .

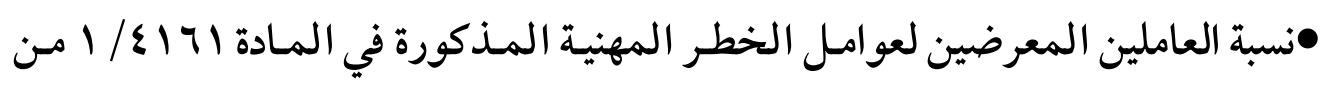
قانون العمل الفرنسى (r) ويتم تحديث هذه الوثيقة كل عـام على الأقـل، أو عنـد اتخـاذ أى قـرار تخطيطلى رئيسى بتعديل شروط الصحة والسلامة أو ظروف العمل ، و كذلك عند جمع أية معلومات إضافية

( (1) وفقا لنص المادة ه 10 من قانون العمل المصرى تلتزم المنشأة وفروعها بـإجر اء تقييم وتحليل

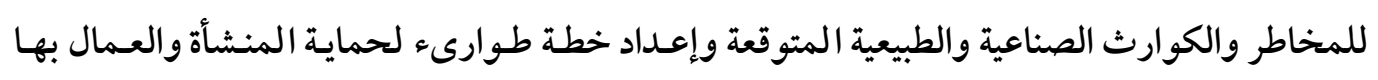

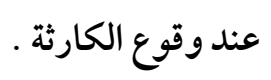

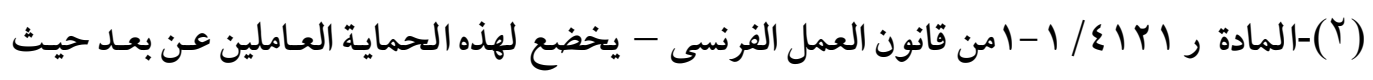

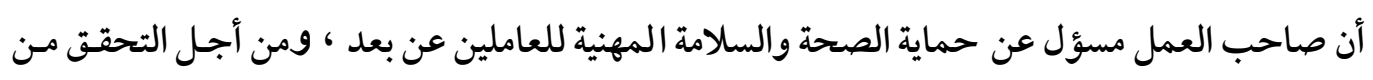

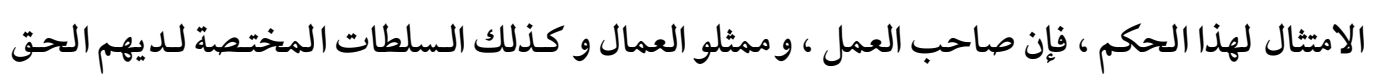

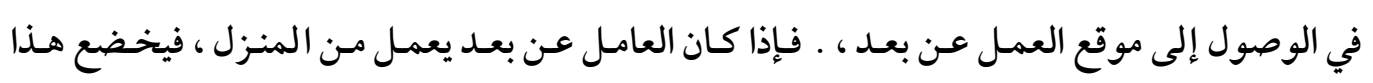

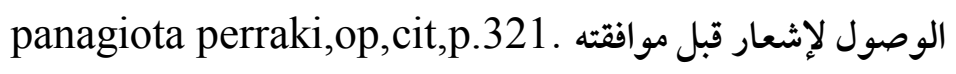


(119६)

ذات صلة بتقيم المخاطر في وحدة العمل (1) .

ويجب أن تكون هذه الوثيقة متاحة للعمال ؛ لذلك يتم نشر إشعار يوضح إجراء إتات وصول

العمال إلى هذه الوثيقة وذلك في مكان مناسب يسهل الوصول إليه في مكان العمل له (ه) . لذلك ستكون المعلومات المعلنة للعامل ، إضافة إلى التزام صاحب العمل بالثدريب هما

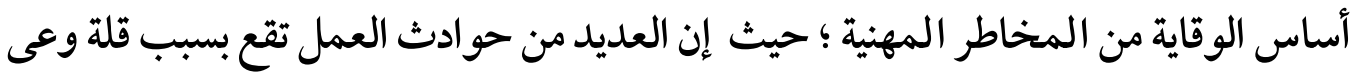
العاملين بالمخاطر الموجودة في الشركة . مالمان.

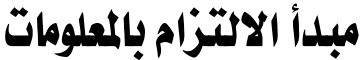

يجب على صاحب العمل أن يقدم للعمال معلومات عن مخاطر الصحة والسلامة المهنية

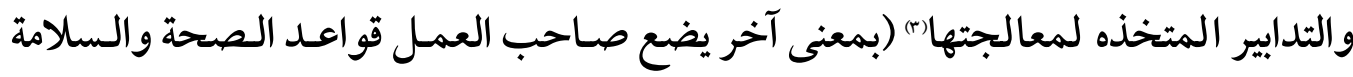

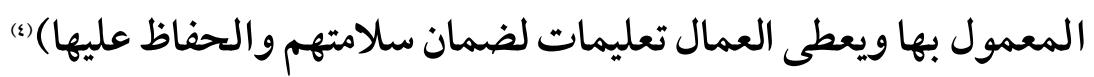
فيقوم صاجب العمل بإبلاغ العمال بالمخاطر التى تهلد صحتهم وسلامتهم بطريقة يمكن

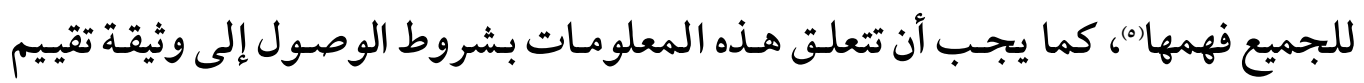
المخاطر ، وتدابير الوقاية من المخاطر المحددة بوثيقة تقييم المخاطر ، ودور خدمة الصحة

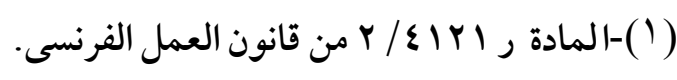

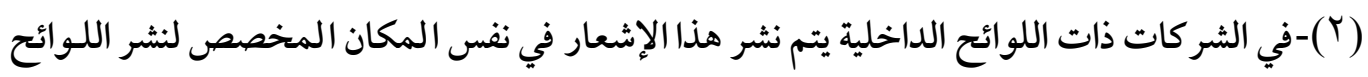

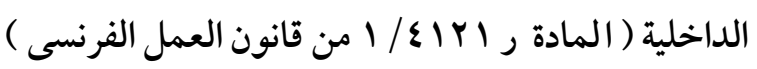

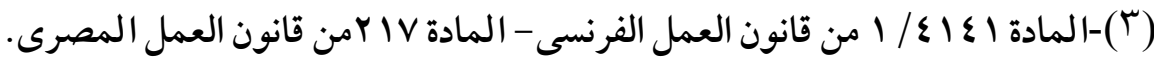

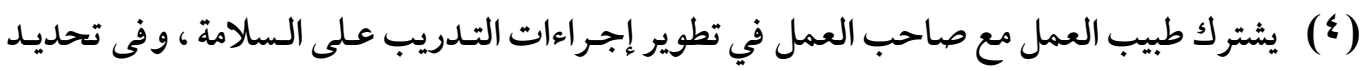

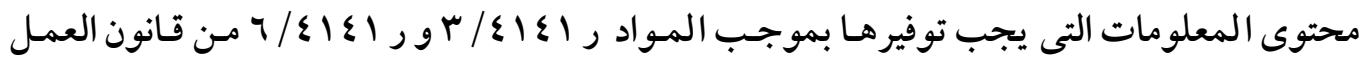
(5) - Lucie Jubert, op,cit,p.519 - Cass. Soc., 11 septembre 2019, no 17-24.879 à 17-25.623 ; à paraître ; JCP S, 2019, act. 335 ; Dalloz actu., 18 septembre 2019, note Luc de Montvalon 


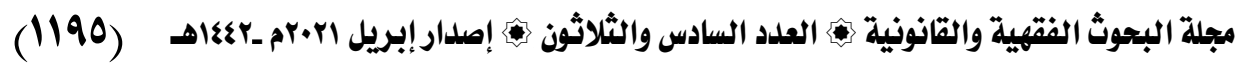
المدنية ، و كذلك دور ممثلى العاملين قى الوقاية من المخاطر المهنية ، والأحكام الواردة في

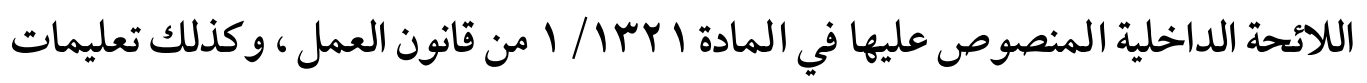
السلامة من الحر ائق الواجب اتباعها في حال وقوع حـادث ، وهويـة الأشـخاص المسئولين

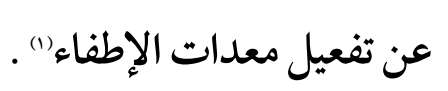

ومع ذلك تتطلب بعض الأحكام الخاصة من صاحب العمل إصدار معلومات عن الوضع الشخصى للعامل فيما يتعلق بمخاطر العمل، فنجد أن صاحب العمل ملزم بإبلاغ العامل كل عام بورقة التقييم الفردى للعو امل المشقة بالنسبة لبعض العاملين" (") .

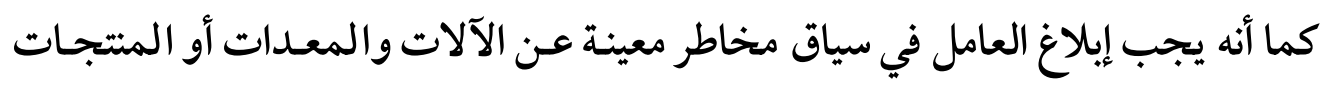

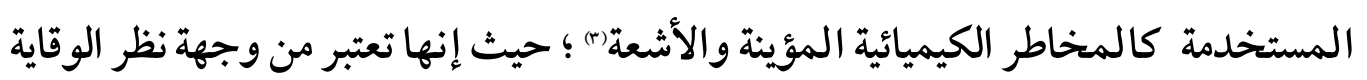
مختلفة عن كل حالات الخطر خاصة وأنها غيرمرئية).

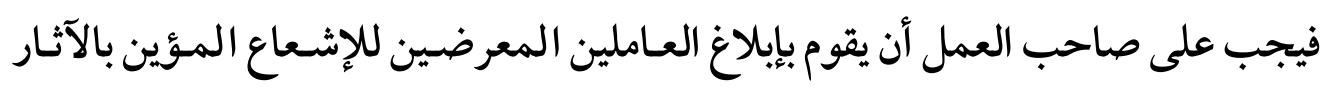

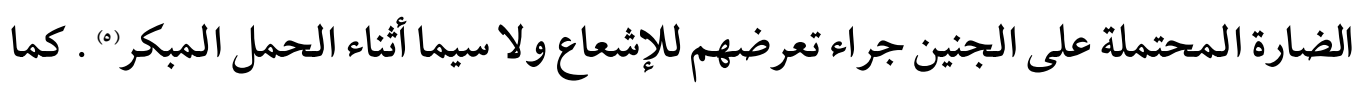

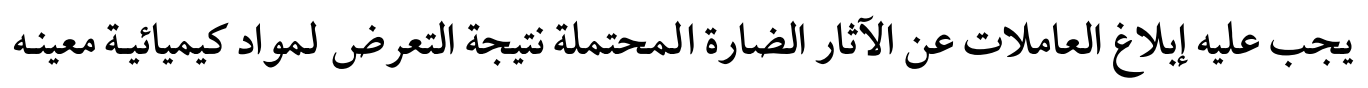

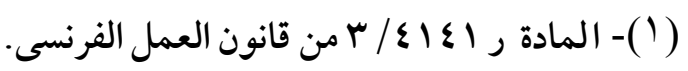

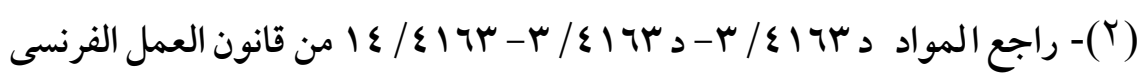

Objet 998 Lucie Jubert, op, cit, p.529

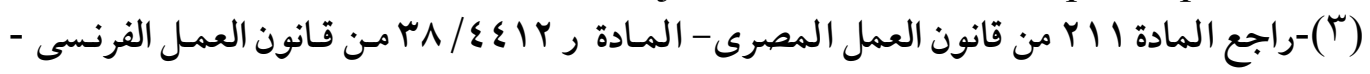

(4)- Lucie Jubert, op, cit, p.370 Objet 693

Lucie Jubert, op, cit, p.529

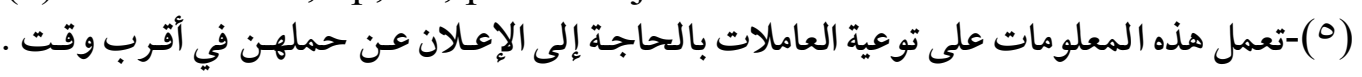

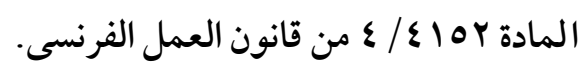


(1197)

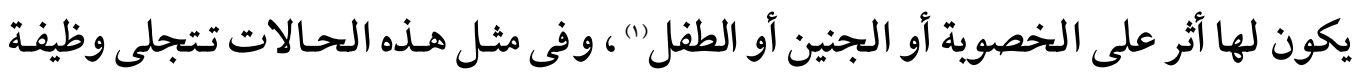

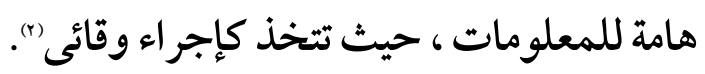

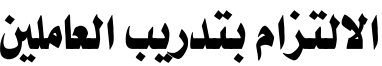

كذلك يجب أن تقترن المعلومات التى يقدمها صاحب العمل إلى العامل بتدريب على السلامة من أجل منع المخاطر المهنية) (مان. حيث يقوم صاحب العمل بإرشاد العامل حول الاحتياطات التى يجـب اتخاذهـا للضضمان

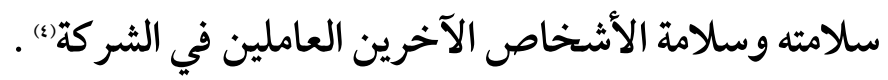

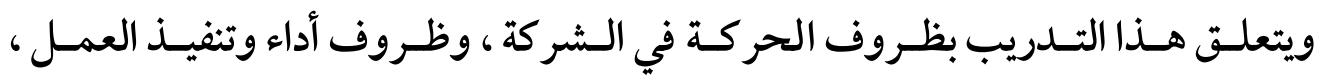
والإجراءات الواجب اتخاذها في حال وقوع حادث أو كارثة ، وفى حال عدم وجود تدريب للعاملين فإن صاحب العمل يصبح مسئو لا جنائيا ومدنياء) . ويعتبر الوقت المخصص للمعلومات وللتدريب وقت عمل ؛ لذلك يجب أن يتم إعطاء المعلومات وإتمام التدرب خلال ساعات العمل العادية . يتضح لنا مما سبق أن المعلومات المتعلقة بمخاطر السلامة والصحة المهنية تنقسم إلى لى قسمين : قسم من المعلومات متعلق بـدور المشاركين في الوقاية ، وقسم ثنانى عبارة عن التعليمات وقو اعد السلامة وطبيعة المواد والمعدات .

(2) - Lucie Jubert, op, cit, p.528 Objet 996

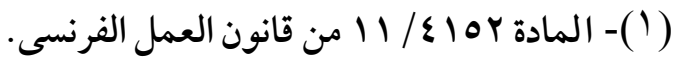

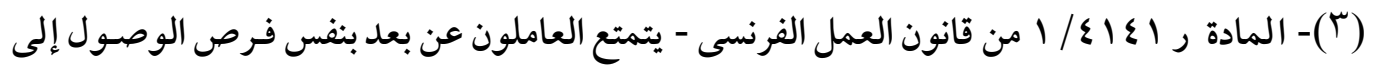

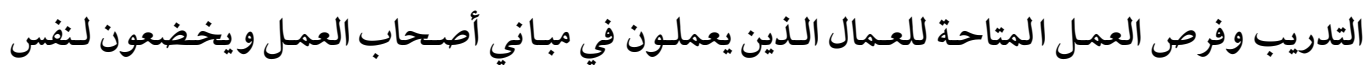

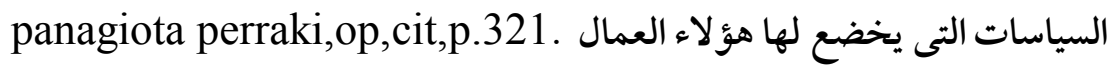

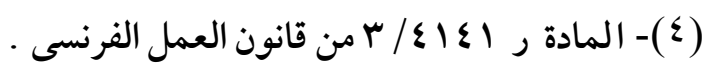

(5)- Cass. soc. 07/05/2014 n॰13-14749- Cass. soc. 30/11/2016 n ${ }^{\circ} 15$ 15162 - Cass. crime, 14 mai $2013, \mathrm{n}^{\circ} 12-81.847$ 


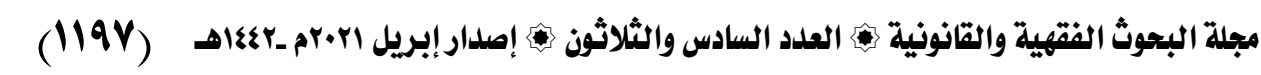
كما يتضح لنا من قراءة أحكام قانون العمل الفرنسى أن التزام صـاحب العمل بـالإبلاغ

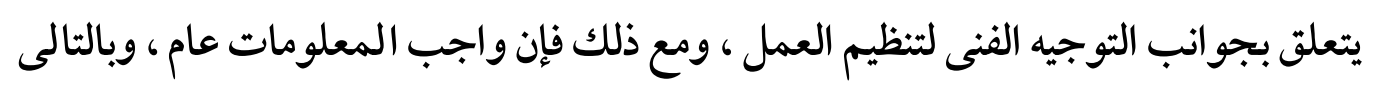

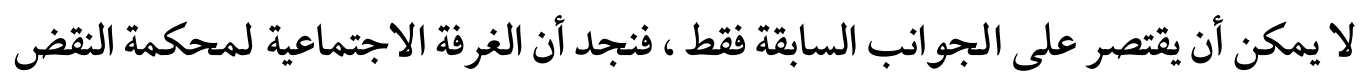

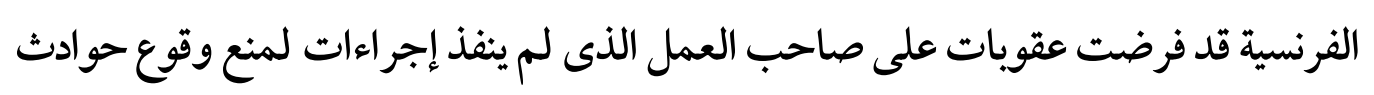

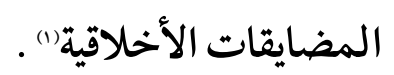

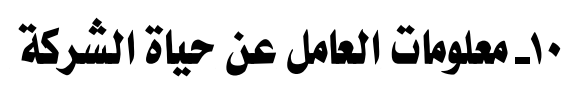

يجب اطلاع العامل على المزيد من المعلومات العامة المتعلقة بحياة الشركة عن طريق النشر (").

فيإذا كـان المـشرع يلـزم الـشر كات والمؤسسـات في أحسوال معينـة بوضـع اللـوائح

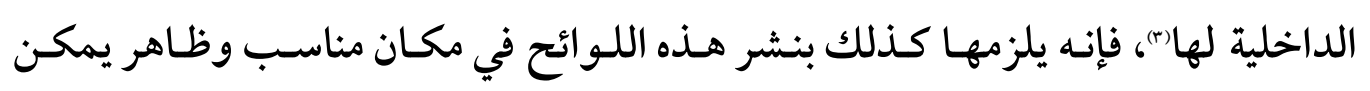

(1)- Cass. Soc., 1 juin 2016, n 14-19.702 ; Bull. civ., V, n 123; RJS, 2016/8, p. 608; JCP G, 2016, 822, note Jean, Mouly; D., 2016, p. 1681, note Julien Icardet Yannick Pagnerre; RDT, 2016, note Benoît Géniaut; JSL, 2016, 413, note Jean-Philippe Lhernould; RTD civ., 2016, p. 869, note Patrice Jourdain. Voir également : Cass. Soc., 5 octobre 2016, n 15-20.140 ; inédit

(2)- A.Lepage ,op,cit,p.150

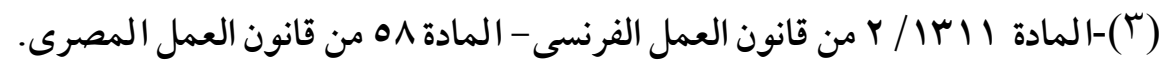


(1191)

الوصول إليه بسهولة في أماكن العمل التى يتم فيها العمل (1) ؛ وذلك حتى يـتمكن العـمال من الاطلاع عليها (ن.).

وتحتوى هذه اللوائح على قو اعد تنظيم العمل والقو اعد المتعلقة بالانضباط ولا سيما مـا

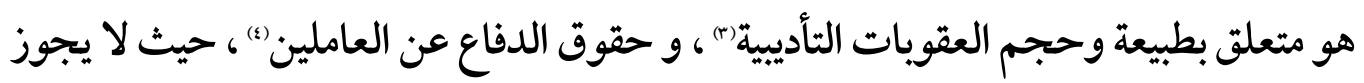

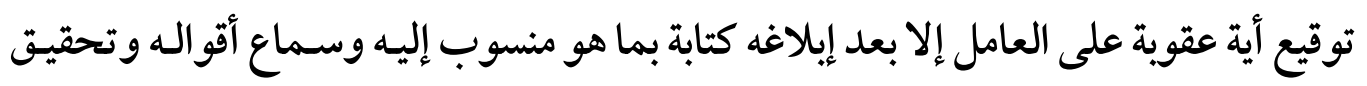
دفاعه وإثبات ذلك في محضر يودع في ملف خاصدا.

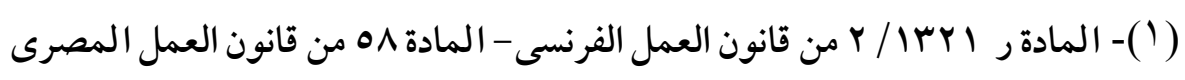

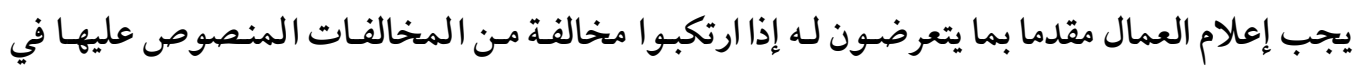
اللائحة.

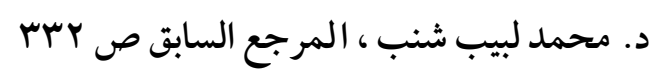

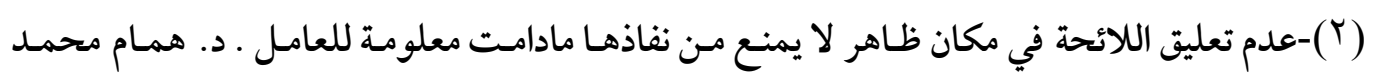

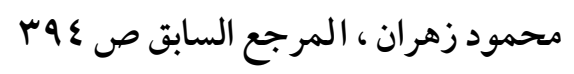

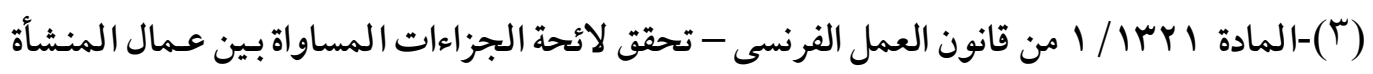

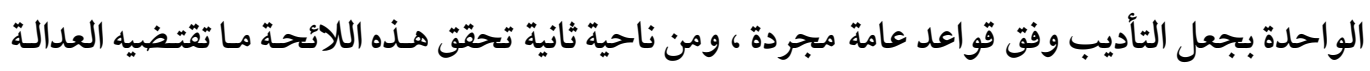

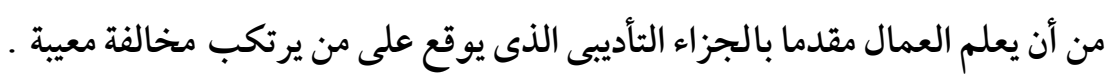

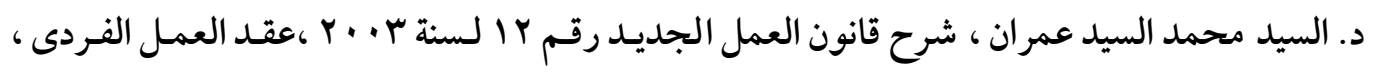

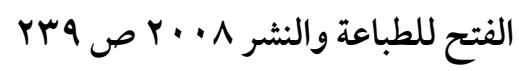

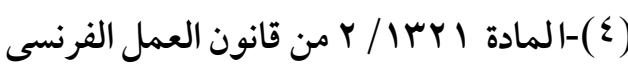

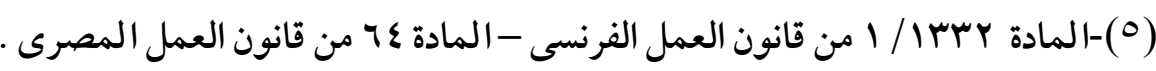

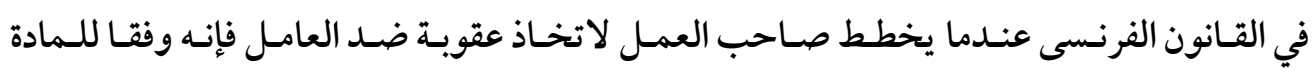

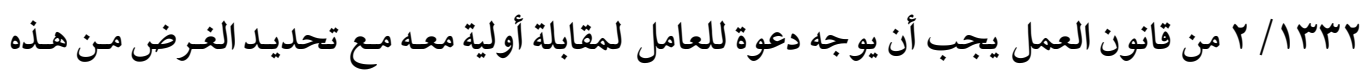

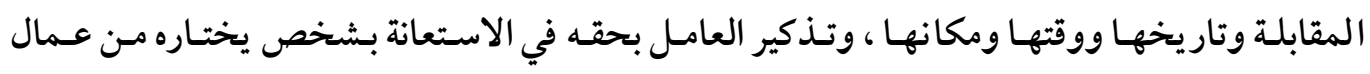

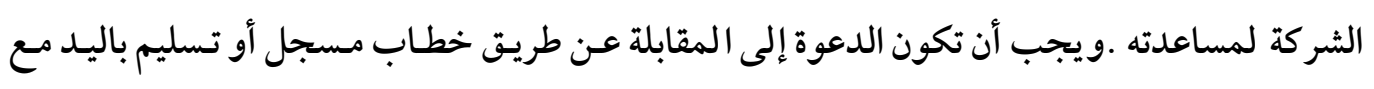




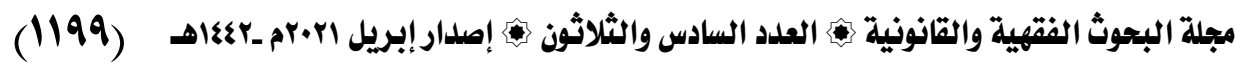
كذلك تحتوى اللوائح الداخلية في القـانون الفرنسى عـلى الإجــ اءات التنفيذيـة لأنظمـة الصحة والسلامة المهنيـة في الشركة أو المؤسسة ، والشروط التى يمكن بموجبها دعـوة

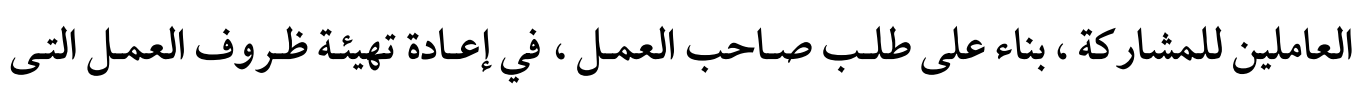
تحمى سلامة وصحة العاملين إذا بدا أنهم معرضون للخطر (1) ، كما تحتوى علمى الأحكام المتعلقة بالتحرش الأخلاقى والجنسى (ب). ولا يجوز أن تحتوى اللوائح الداخليـة عـلى أحكـام مخالفـة للقـوانين وأحكـام اتفاقيـات العمل الجماعية المعمول بها في الثر كة أو المؤسسة ، كما لا يجوز أن تفرض قيوداعـلى حقوق الأفر اد والحريات الفردية(م)، ولا أن تحتوى اللوائح الداخلية على أحكام تمييز ضـد أحس العاملين في وظائفهم أو عملهم (s) ، ومع ذلك يمكن أن تحتوى على أحكام تنص على حيـاد العامل وتقييد التعبير ؛ وذلك إذا كانت هذه القيود مبررة بممارسـة حقوق وحريـات أساسية أخرى أو بضرورات الأداء السليم للشركة إذا كانت تتناسب مع الهدف المنشوددم . .

التوقيع (وفقا للمادة ر بrr / / ا عمل ) ويـتم إبلاغ العامـل بالعقويـة وبأسـابها كتابـة عن طريق طريق

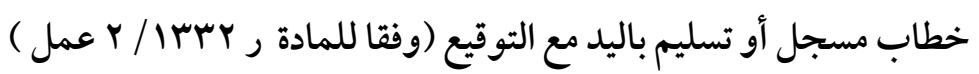

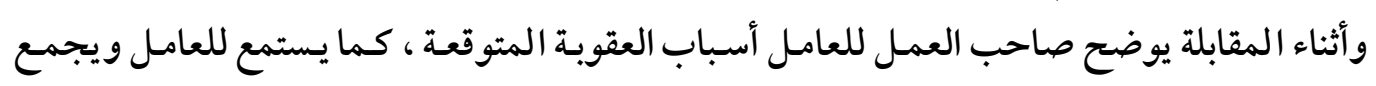
تفسير اته بخصوص الخطأ التأديبى المنسوب إليه.

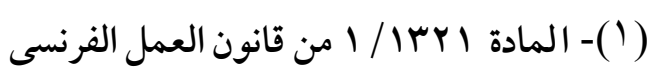

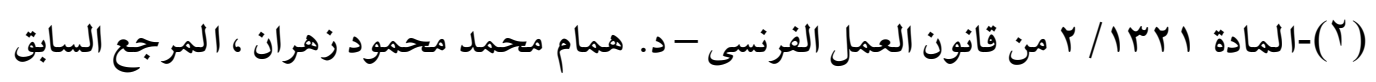
ص ص p

(3) - Panagiota Perraki, op , cit,.p.90

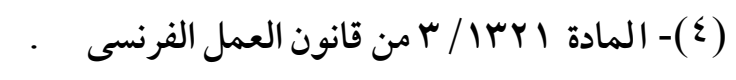

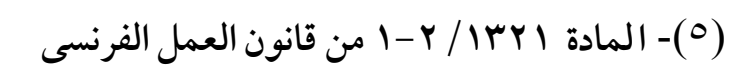


(Ir.•)

و حتى يتم تطبيق اللوائح الداخلية ، يجب على صاحب العمل إكمال إجراءات التسجيل

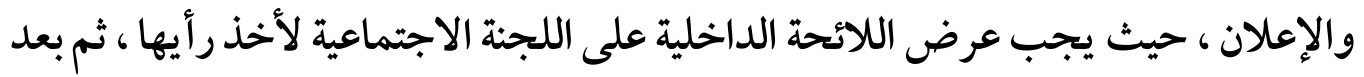
ذلك يتم إبلاغ مفتش العمل ، ولا يـتم العمل بهـا إلا بعـد مرور مـدة شهر مـن اكتمال هـذهـ

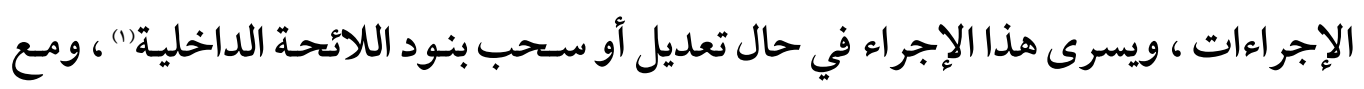
ذلك فيمكن تطبيق الالنزامات المتعلقة بالصحة والسلامة المهنية على الفور عندماتها تبرر الضرورة ذلك ، وفى هذه الحالة يتم على الفور وفى نفس الوقت إبـلاغ اللجنة الاجتماعية

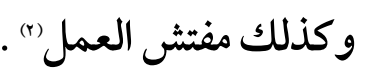
كذلك يوجد الكثير من المعلومات المتعلقة بحياة الشر كة أو المؤسسة التى يجـب أن

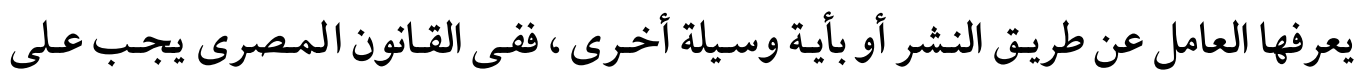

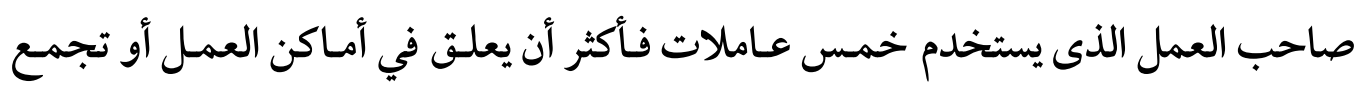

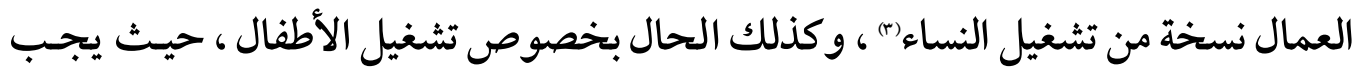
على صاحب العمل الذى يقوم بتشغيل طفل أو أكثر أن يعلق في مكان ظاهر في محل العمل نسخة تحتوى على أحكام عمل الأطفال(s).

في قانون العمل الفرنسى يلتزم صاحب العمل بأن يضع ، في أماكن يسهل الوصسول إليها

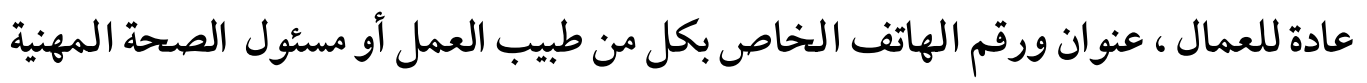

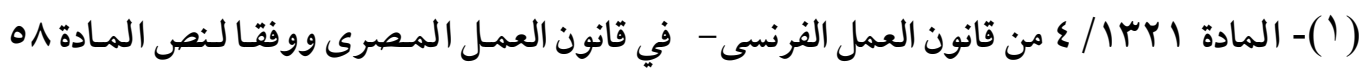

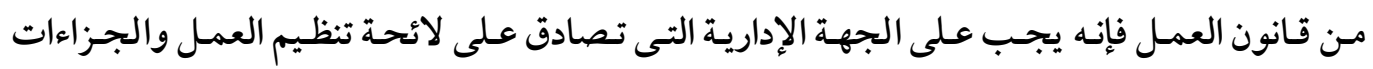

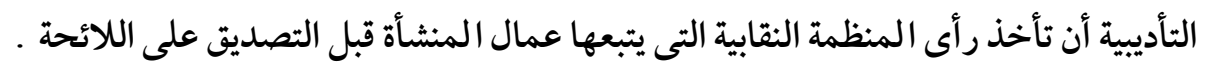

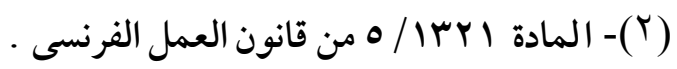

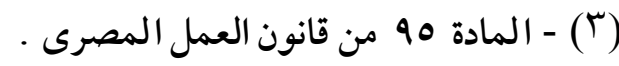

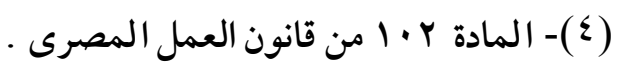




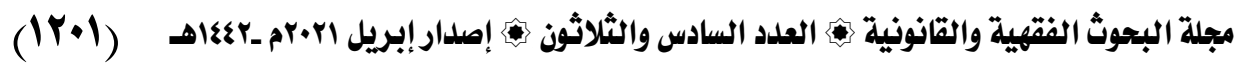

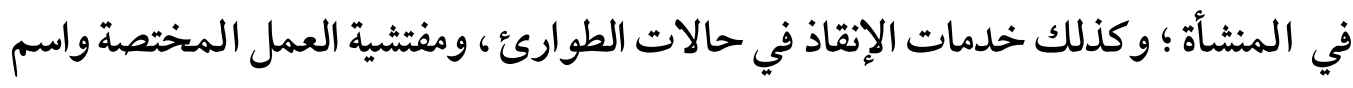

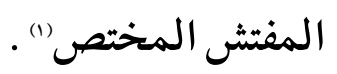
كما يجب إبلاغ العامل بترتيب القيام بالإجازة ، بأي وسيلة ، قبـل شهـر مـن تركه العمل للقيام بالإجازة). كما قرر قانون المشرع الفرنسى بخصوص الر احة الأسبوعية في الشركات والمؤسسات

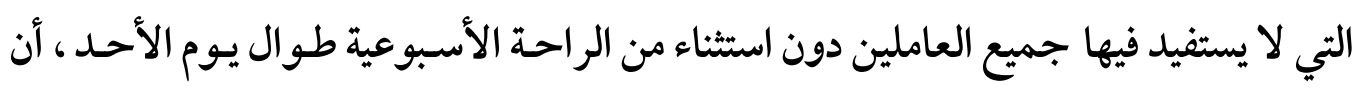

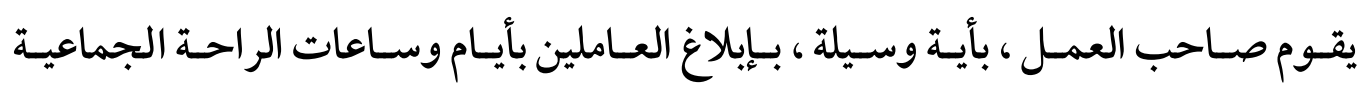

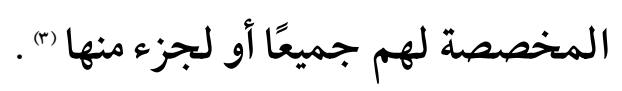

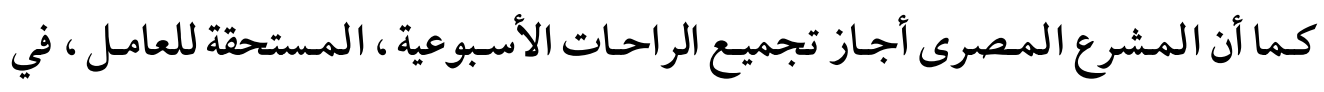

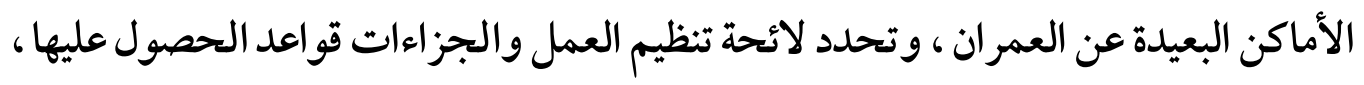

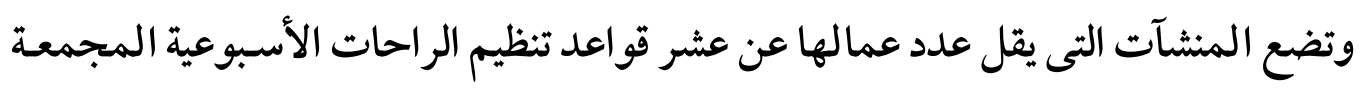
بها وفقا للفر ارات التى تصدرها المنثأةث).

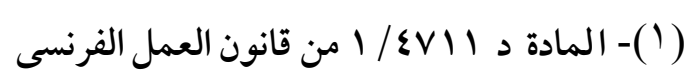

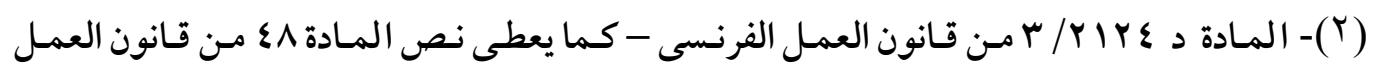

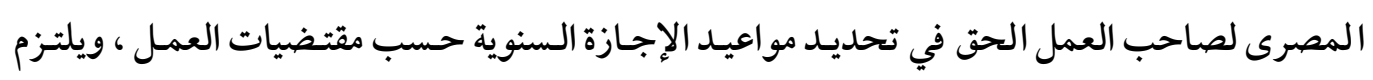

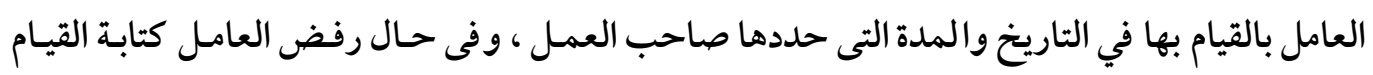
بها سقط حقه في اقتضاء مقابلها.

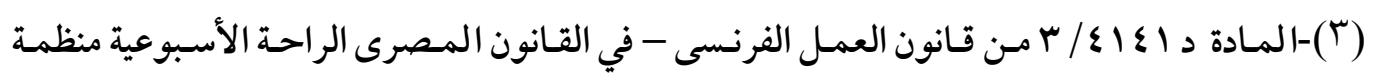

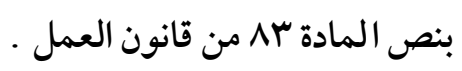

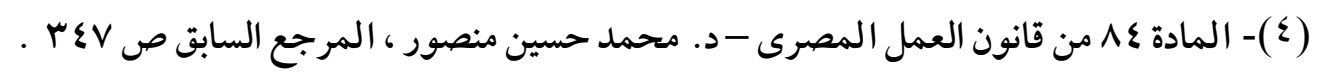


كما يجـب إبـلاغ العـاملين بوجـود و محتوى اتفاقيـة المـشاركة في الأربـاح بأيسة وسـيلة منصوص عليها في هذه الاتفاقية ، وفي حالة عدم القيام بذلك ، عن طريق النشر (1) .

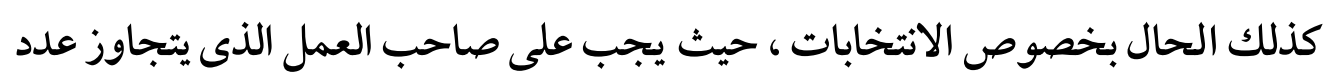

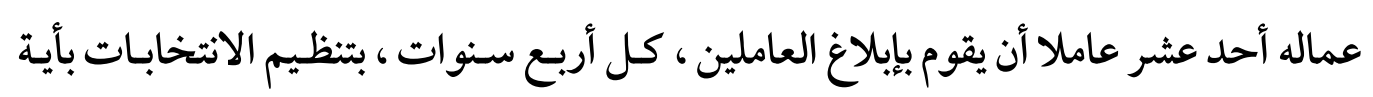

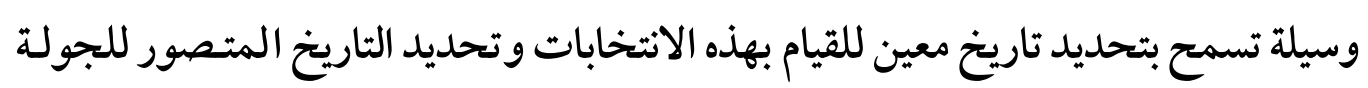

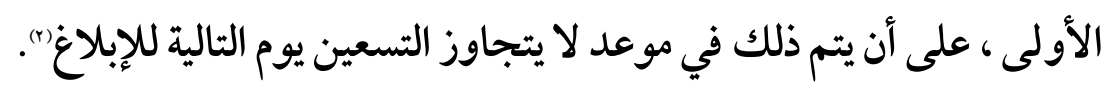

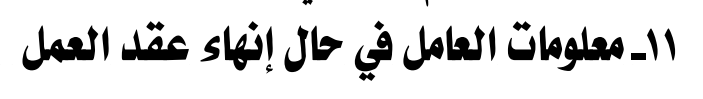

قد يتم إنهاء عقد العمل بالاتفاق المتبادل ، ومع ذلك مـن الشائع أن ينتج فقط مـ إرادة طرف واحد سواءًا أكان العامل أو صاحب العمل.

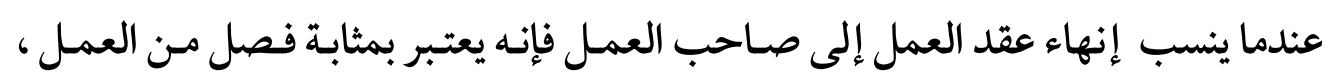

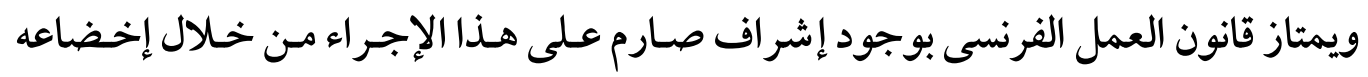

$$
\text { للعديد من الالتزامات الشكلية والموضوعية"). }
$$

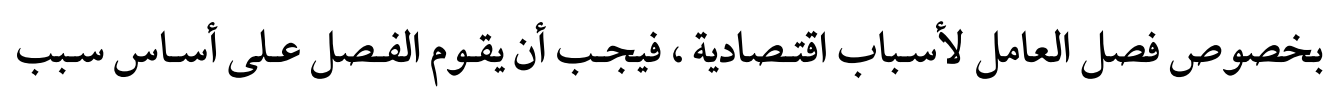

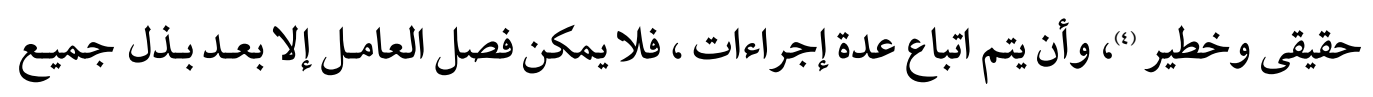

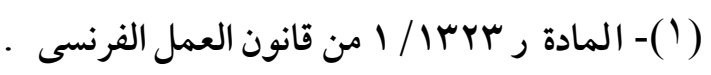

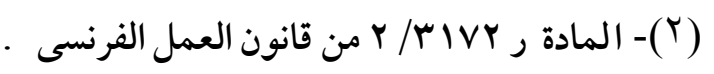

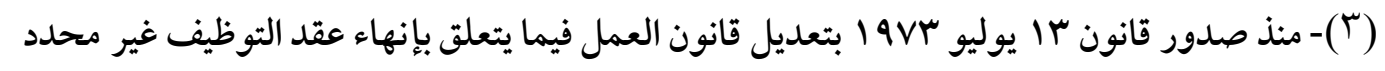




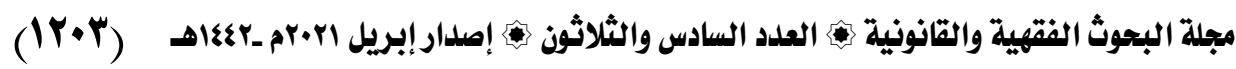

الجهود اللازمة لتدريب وتكييف العامل مع المهام الجديدة'(1) ، وبحيث تكون عروض إعـادة التصنيف مكتوبة ودقيقة ، وتتم على وظيفة تتدرج ضسمن نفس الفئة التى يشَغلها العامل أو وظيفة معادلة بأجر معادل ، وفى حال تعذر ذلك ووفقا لمو افقـة العامل الصر يحة تـتم إعـادة التوزيع على وظيفة في فئة أقل (r) . في حال تعذر إعادة التصنيف(r) وأراد صاحب العمل الشروع في عمليـة الفصل لأسباب اقتصادية() فإن هذا الفصل يمر حتما بثلاث مر احل مميزة للغاية(0) وهى على النحو التالى:

\section{المرحلة الأولى : دعوة العامل للمقابلة الأولية مذابلية}

يجب على صاحب العمل إرسال دعوة للعامل لإجر اء مقابله معه قبل الفصل ، وتتـم هـذه الدعوة وفق شكلين محددين ، إما بخطاب مسجل أو برسـالة يتم تسليمها باليـ للعامل (1) ،

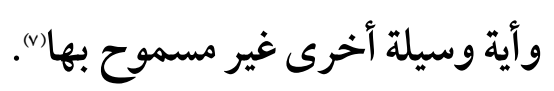

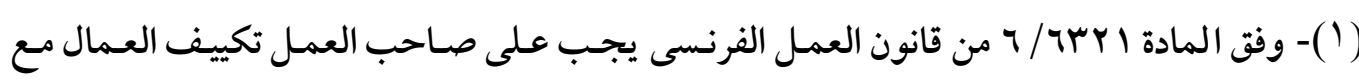

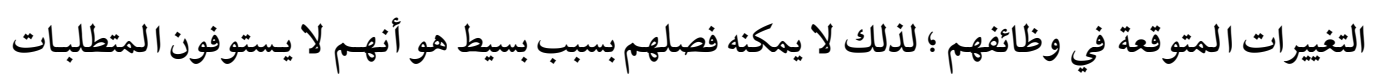

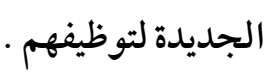

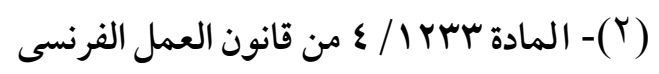

(T)- قد تنص الاتفاقية الجماعية على تقييم بخلاف ما ينص عليه قانون العمل ، وبالفعل فقد تم الحكم

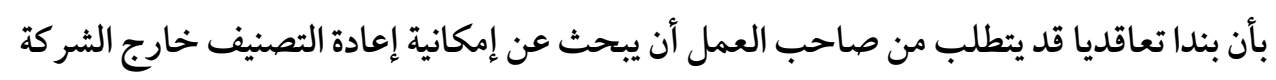

Cass. soc., 28 mai 2008, n 06-460090

$$
\text { (๕) - يتم تقييم الصعويات الاقتصادية في تاريخ الإخطار بالفصل }
$$

Cass. soc., 9 Nov 2009, n $08-43648,2009$

(5)-Manoëlla RASSELET, LES RUPTURES DU CONTRAT DE TRAVAIL, these, UNIVERSITÉ DE NANTES.2007, P.572

$$
\text { (7) (7) المادة سrr / / } 11 \text { من قانون العمل الفرنسى }
$$

(7)- Manoëlla RASSELET op,cit, p.573-Cass. soc., 13 septembre 2006, n 0445.698, CSBP, janvier 2007, n०186, S 15, obs. F.-J. PANSIER; JCP, S, n 4445 du 31 octobre 2006, 1862, note D. CORRIGNAN-CARSIN ; RJS11/06, n'1164. 


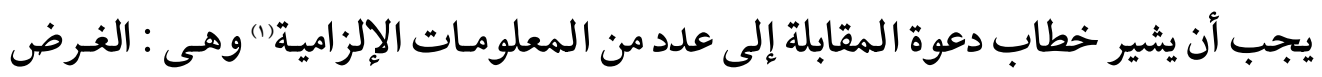

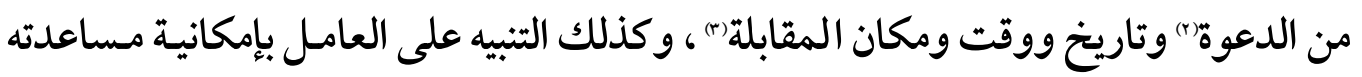
من قبل شخص من اختياره يتتمى إلى عمال الشر كة أو الاستعانة بمستشار من خارج الشركة إذا لم يكن هناك ممثلون عن العاملين في الشر كة").

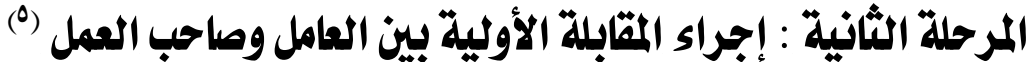

وحيث إن المقابلة هدفها الوحيد هو مصلحة العامل ، والعمل على تجنب فقدانه لوظيفته ؛

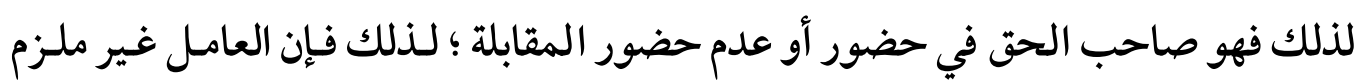

$$
\text { (1) (1) (1) }
$$

Manoëlla RASSELET op,cit, p.574

(Y) - يجب أن يشير الخطاب بإشارة لا لبس فيها إلى أنه من المتصور فصل العامل ، وفى غياب هـذه

$$
\text { الإشارة فإن محكمة النقض الفرنسية تعتبر الفصل غير مشروع. }
$$

Cass. soc., 16 janvier 2007, Jur. soc., avril 2007, p.132

(َّ)- السوابق القضائية تحصرمكان المقابلة في مكان تنفيذ العمل أو المركز الرئيسى ، وذلك مـا لم

$$
\text { توجد ظروف تبرر تغيير مكان المقابلة إلى مكان آخر . }
$$

Cass. soc., 9 mai 2000, no7-45.294, Bull. civ., V, n¹71

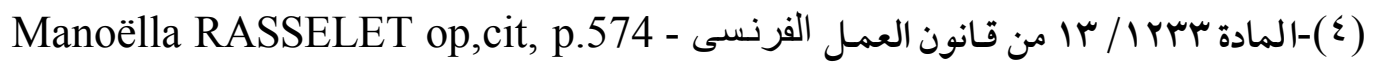

$$
\text { وانظر الأحكام القضائية : }
$$

Cass. soc., 5 mars 1997, CSBP1997, S 88 - Cass. soc., 6 février 2001, n98-43.597, Bull. civ., V, n०44 - Cass. soc., 29 avril 2003, n01-41.364, Bull. civ., V, $\mathrm{n}^{\circ} 145$; CSBP2003, n¹52, S 330, obs. C. CHARBONNEAU ; RJS7/03, n'860; TPS, juillet 2003, n²54, p.19

(0) يلتزم صاحب العمل بإجر اء مقابلة سابقة على الإنهاء بصرف النظر عن حجـم المنشأة كبيرة أو

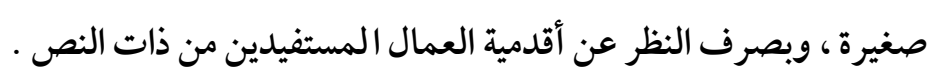

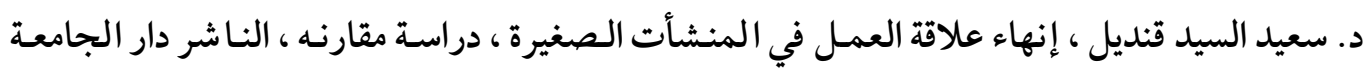

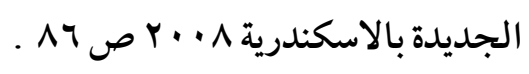




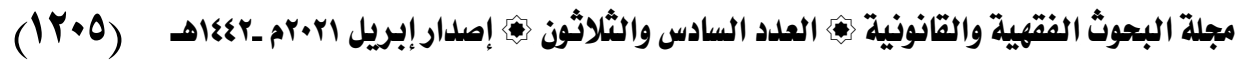

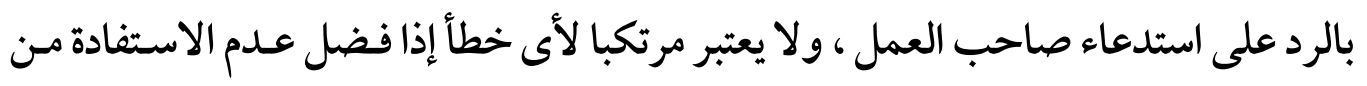
هذه القاعدة الإجرائية وقرر عدم حضور المقابلة').

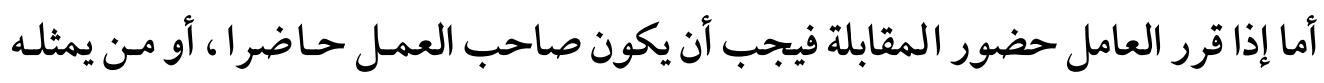

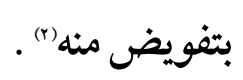
ولا تتم المقابلة على الفور بمجرد استلام العامل للدعوة للمقابلة ، وإنما يلزم قانون العمل

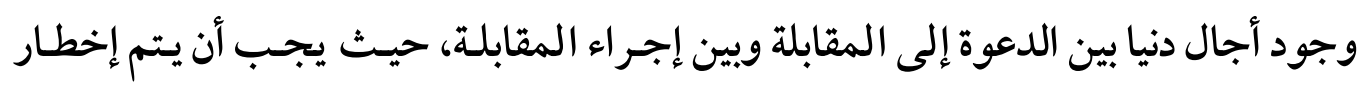

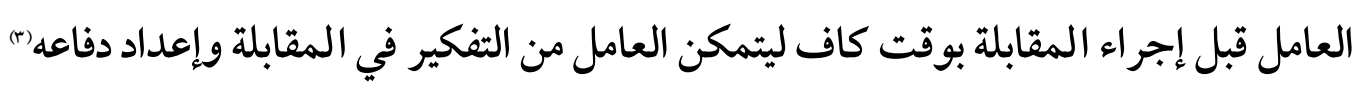

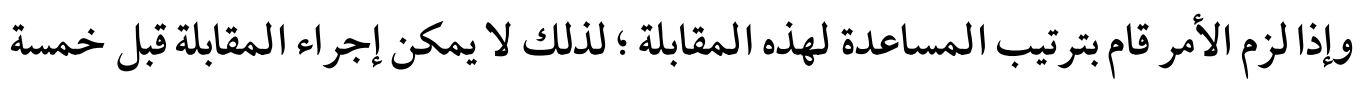
أيام على الأقل بعد استلام العامل لخطاب الدعوة للمقابلة (s) .

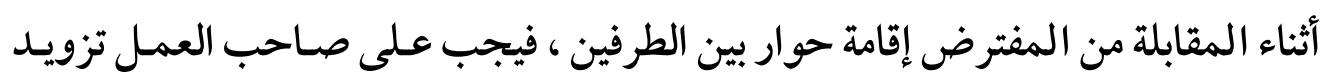

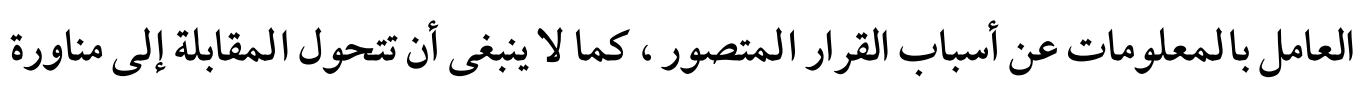

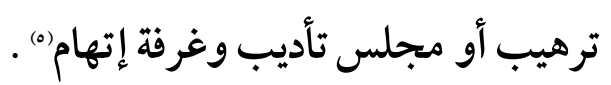

(1)- Cass. soc., 15 mai 1991, n89-44.670, Bull. civ., V, n²35; RJS6/91, n740.

Cass. soc., 28 novembre 2001, n98-41.308, Bull. civ.,V, n³94 ; RJS2/02, $\mathrm{n}^{\circ} 157$.

(2)- Cass. soc., 26 mars 2002, $\mathrm{n}^{\circ} 99-43.155$, CSBP2002, $\mathrm{n}^{\circ} 141$, S 267, obs. C. CHARBONNEAU ; Dr. soc.2002, p.784, obs. J. MOULY; JCP, G, 2002, IV, 1837 ; RJS6/02, n669; TPS, juin 2002, n ${ }^{\circ} 176$, p.12

(3) - Manoëlla RASSELET op,cit, p.575

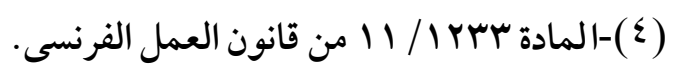

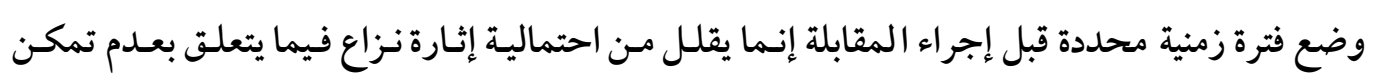

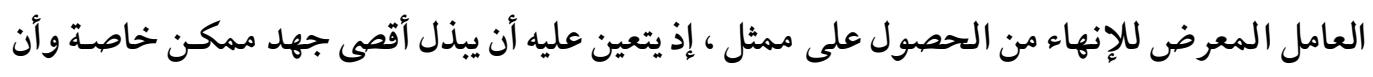

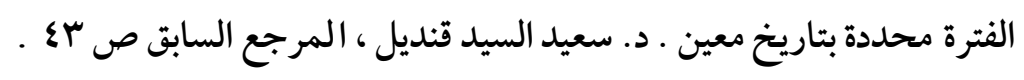
(5) - Manoëlla RASSELET op,cit, p.577 Objet 525 


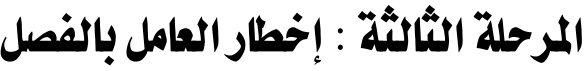

بعد انتهاء المقابلة لا يوجد إلزام على صاحب العمل بكتابة تقرير عما تم فيها")، كذلك لا

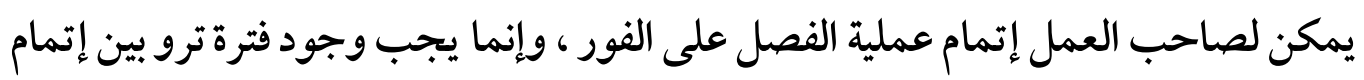
المقابلة وقرار الفصل ؛ حتى يتم السماح لصاحب العمل بعدم التسرع في اتخاذ قرار الفصل.

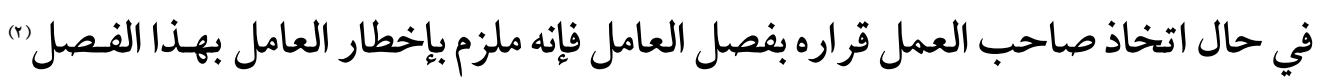
بخطاب مسجل بعلم الوصول وذلك في خلال فترة لا تقل عن سبعة أيام بعد إجر اء المقابلة

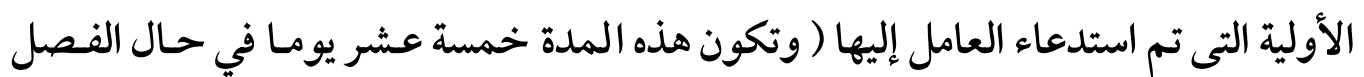

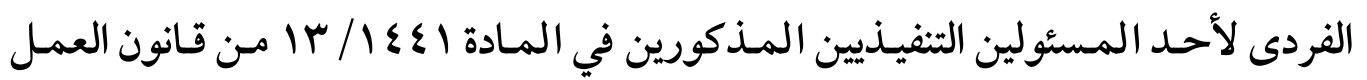

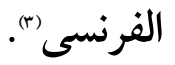
يجب أن يتضمن خطاب الفصل معلومات عن الأسباب الاقتصادية للفصل (s)، كما يشير

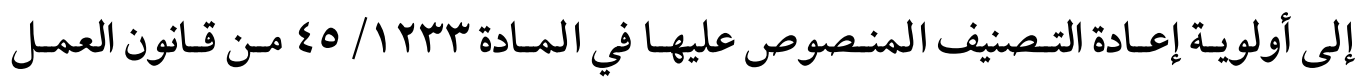

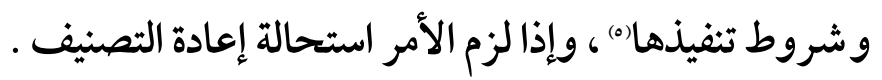

(1) - Ibid Objet 527

(T) - - يتم تقييم الصعوبات الاقتصادية من تاريخ الإخطار بالفصل.

Cass. soc., 9 Nov 2009, nº $08-43648,2009$

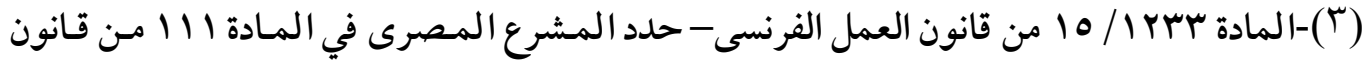

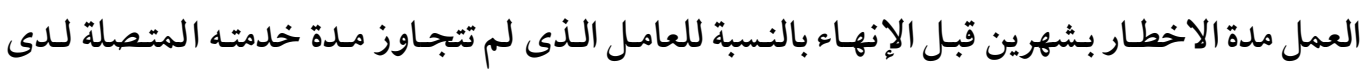
صاحب العمل عشر سنوات ، وحدد ثلاثة شهور لمن زادت مدة خدمته عن عشر سنوات متصلة.

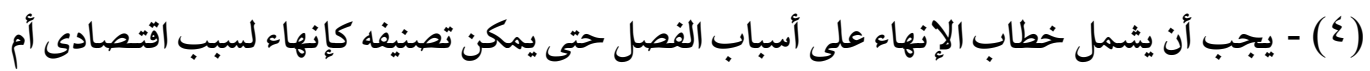

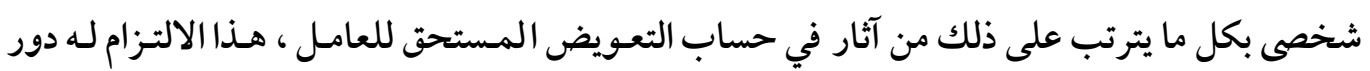

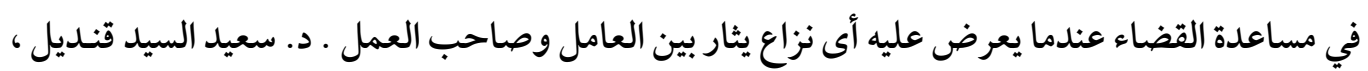

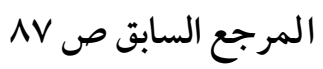

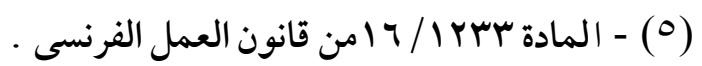




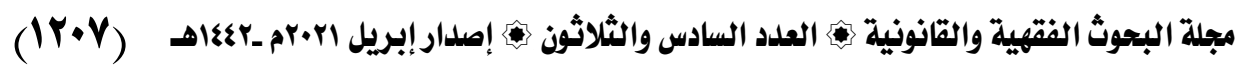
خاتمة اللدراسة

\section{في ختام هذه اللدراسة يمكن استخلاص النتائج التالية :}

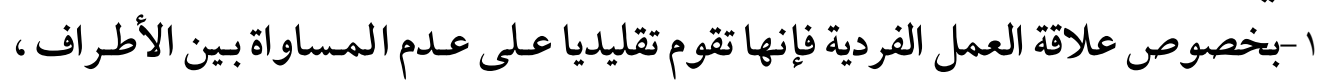
حيث يتفوق صاحب العمل من خلال التبعية القانونية التى تلزم العامل حتما بصاحب العيل العمل.

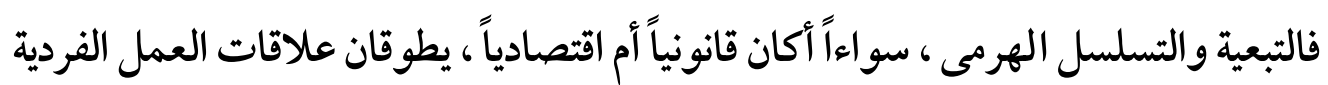

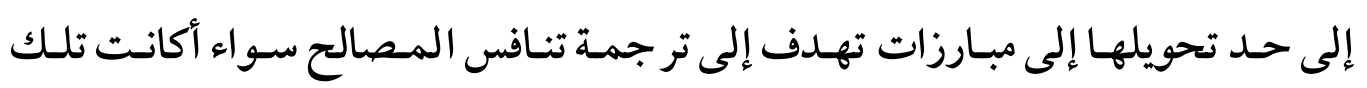

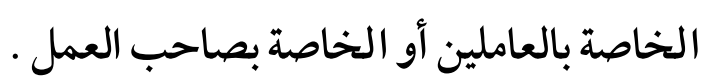

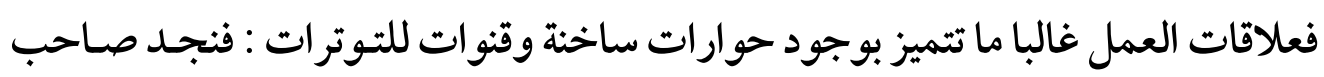

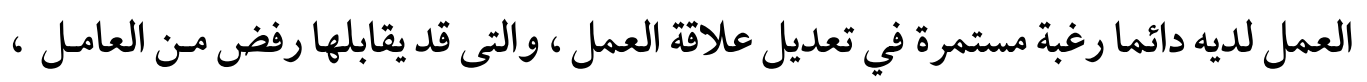

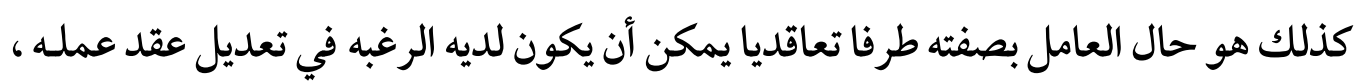
وذلك دون أن يشكل هذا في حد ذاته سوء سلوك مهنى معاقب عليه .

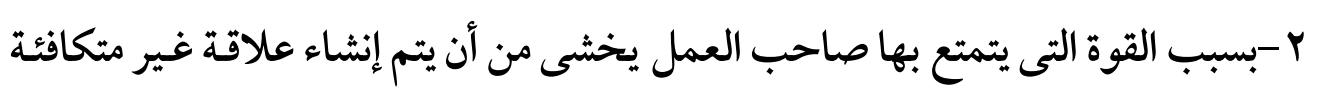

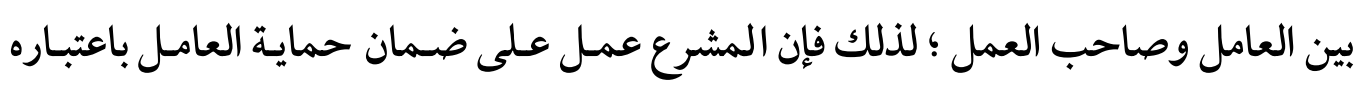
الطرف الضعيف ضد إساءة استخدام السلطة المحتملة ؛ وذلك ببناء نظام حمايـة إلزامى لئى

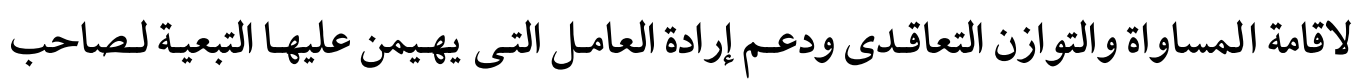

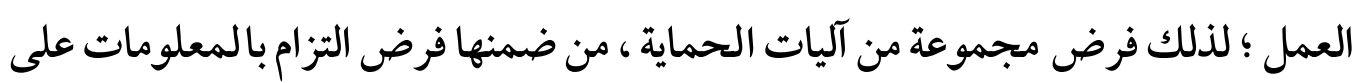

قديتضمن عقد العمل بنداًتعاقدياً يوجـب على صـاحب العمل البحث عن إمكانية إعادة التصنيف خـارج

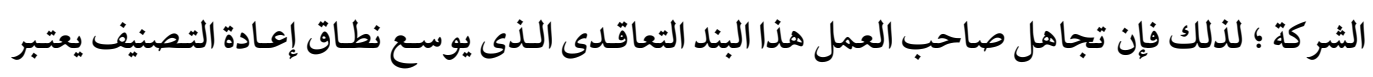

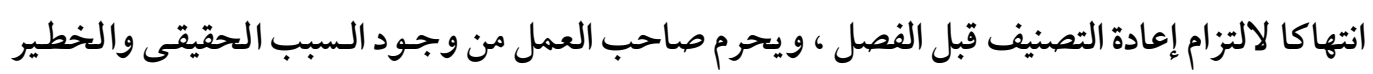

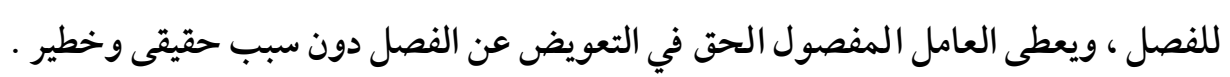
Cass. soc., 28 mai 2008, nº 06-460090 
$(M+1)$

صاحب العمل الذى يكون لديه معلومات لا يعرفها العامـل ؛ بهدف التوضيح والشفافية وتقليل الهيمنة التى يعانى منها العامل وضمان استعادة المساواة في العقد.

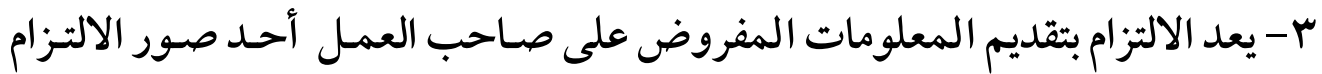
بالمعلومـات المفـروض في جميع العقـود في القـانون الفرنسى ، حيـث كرس المشـرع

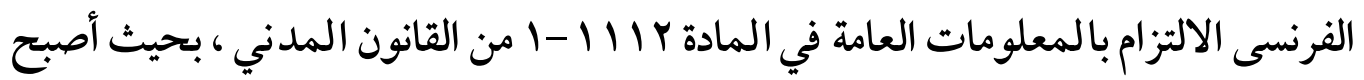
له أساس نصي خاص به. كما أنه الآن منفصل تمامًا عن الأسس القانونية الأخرى التي كانت مرتبطة به تقليديًا - كان يتم ربط الالتزام بالمعلومات العامة من خلال السو ابق القضائية بمبدأ

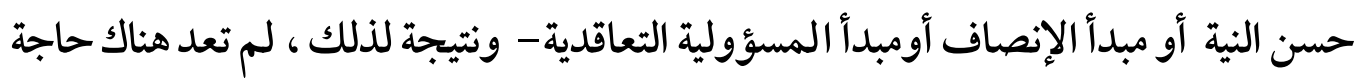

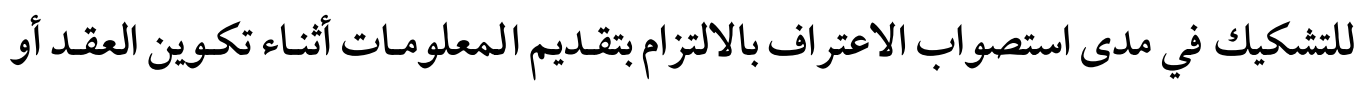
عند تنفيذه ؛ لذلك لم يعد من الممكن اعتباره التزامًا إضافيًا لنظرية عيوب المئم الموافقة.

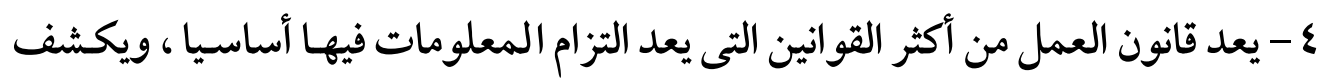

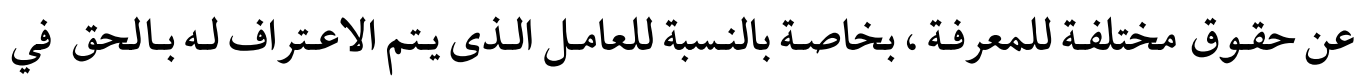

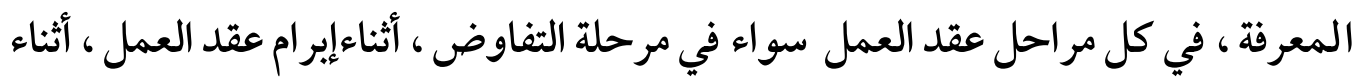
تنفيذه ، وأيضًا أثناء إنهائه. فالتزام صاحب العمل بالمعلومـات يعـد ضـمن آليات حمايـة حـق العامل في المعرفة

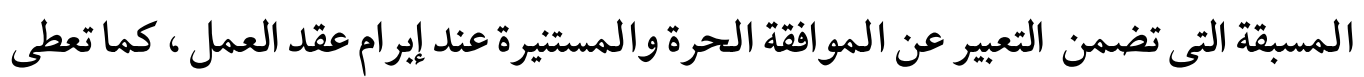

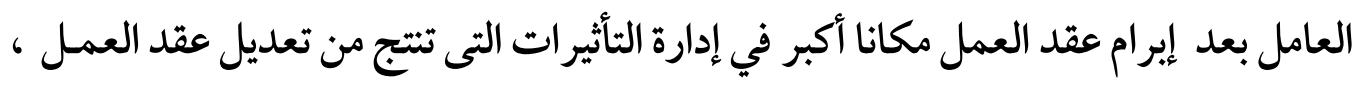

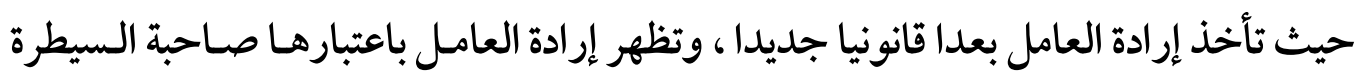

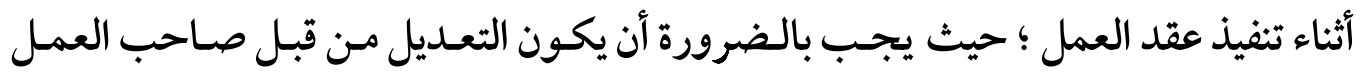

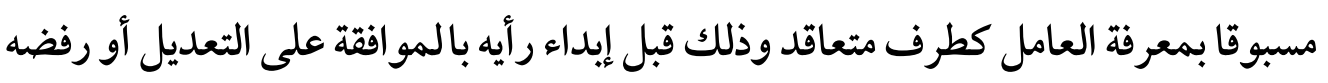




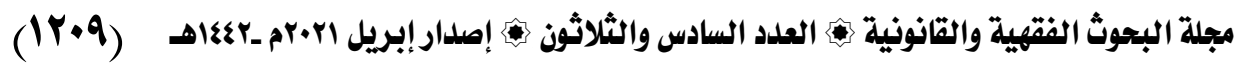

\section{قائمة المراجع}

\section{أولا : المراجع بالالة المريبية}

إ-المؤلثات العامة : المرعة

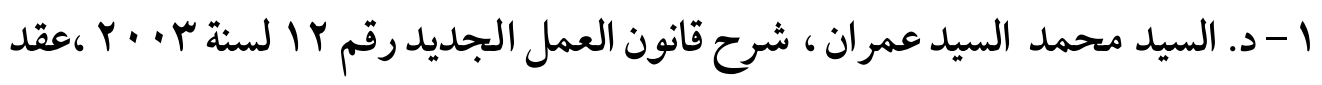

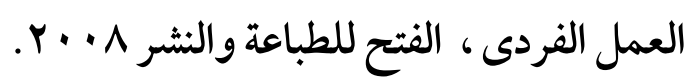

ץ-د.توفيق حسن فرج ، قانون العمل الجديد ، تنقيح وائل بندق ، النا شر مؤسسة إبر اهيم

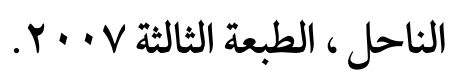

r-د. عصام أنور سـليم ، الوجيز في قـانون العمل ، ، دار الجامعـة الجديـدة بالإسكندرية

$$
r+19
$$

ع -د. محمد حسين منصور ، قانون العمل ، النـاشر دار الجامعـة الجديـدة بالإسكندرية

$$
r+11
$$

ه - د. محمد لبيب شنب ، شرح أحكام قانون العمل ، تنقيح وائل بندق ، الطبعة السادسة

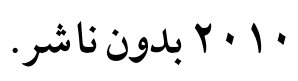

Y-د. مصطفى عبد الحميد عدوى ، الوجيز في قانون العمل ، بدون ناشر ، 1999

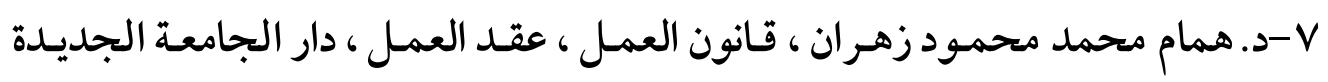

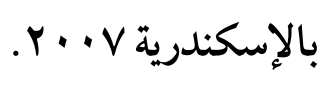

\section{rالمؤلفات المتخصصة والرسائل والمقالات}

1 - د. خالد حمدى عبد الرحمن ، الحماية القانونية للحياة الخاصة للعامل ، النـاشر دار

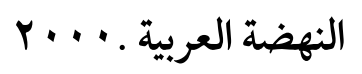

Y - د. سعيد السيد قنديل ، إنهاء علاقة العمل في المنشأت الصغيرة ، دراسة مقارنه ،

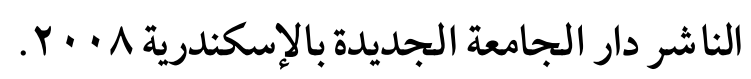

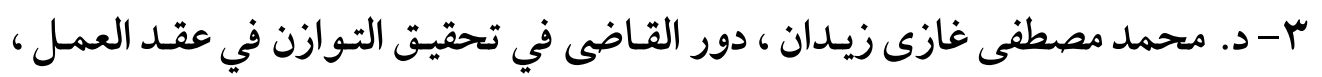




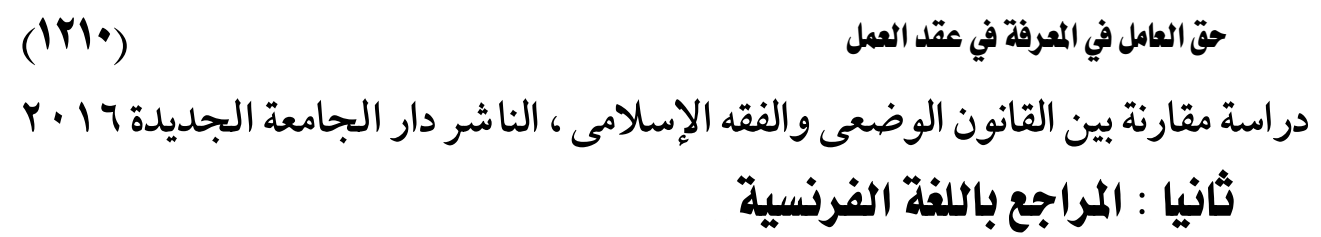

1-Ouvrages généraux ,course et traits

1- j. Pelissier. G. Auzero et e. Dockes, droit du travail, précis dalloz, 2013.

2- Outrages spéciaux et thèses

1-A.Lepage, Avant-propos à l'étude Le droit de savoir, Rapport annuel de la Cour de cassation 2010, La Documentation française, 2011.

2- Année Séverine DHENNIN, la nullité du contrat de travail, Thèse, UNIVERSITE DE DE LILLE2, 2001

3- Aurélia Le mettre. Les critères du contrat de travail, Master de droit et pratique des relations de travail, Université Panthéon Assas Laboratoire de droit social,2010

4- B. Boubli : Sur les modification du contrat de travail et la loi Aubry - Semaine sociale Lamy 1998.

5- Franck PETIT, la modification du contrat de travail, Le Droit Ouvrier• AOÛT2016

6- Grégoire LOISEAU, La neutralisation du dol du salarié, D. 2006

7- Henrik de Brier, - La mobilité du salarié, Thèse, Université d'Avignon, 2015

8- J. MOULY, note sous Soc. 3 juil. 1990, D. 1991

9- Jean PÉLISSIER. La détermination des éléments du contrat de travail, le Droit Ouvrier, MARS 2005

10- Léa Amic, La loyauté dans les rapports de travail, THÈSE, Université d'Avignon, 2014

11-Lucie Jubert, L'organisation du travail et la prévention des risques professionnels, Thèse. l'Université Paris Nanterre , 2019.

12- M.-A. PEANO, Lřintuitus personae dans le contrat de travail, Dr. soc. 1995.

13- madame alice mannes, la conscience en droit social, these , universite pantheon-assas (paris ii) 2018.

14- Marie Annick PÉANO, L'intuitu personae dans le contrat de travail, Dr.soc. 1995

15- Martine GOURVES épouse BARBIER, La volonté du salarié dans le rapport de travail, Thèse, Université Lumière Lyon 2, 2010.

16-Manoëlla Rasselet, Les Ruptures Du Contrat De Travail,These, 


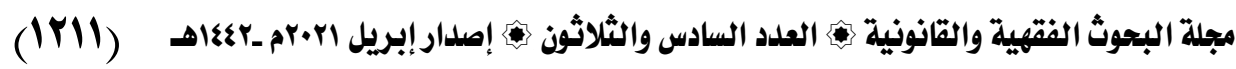

Université De Nantes.2007

17- P.H. Anton Mattei : Les éléments du contrat de travail - Dr. Social 1999.

18- Panagiota Perraki, La protection de la vie personnelle du salarié en droit comparé et européen : étude comparative des droits français, hellénique, britannique et européen, thèse, université de Strasbourg 2013

19- Sangare Yacouba, Les Sanctions En Droit Du Travail, These , Universite De Cergy-Pontoise, 2012

20- Serge Diena Diakiese: Modification du contrat de travail en vertu de la loi congolaise,Université protestante au Congo, l'année académique 2004/2005. 
$(|r| r)$

حق العامل في المعرفة في عقد العمل

فهرس البجتث

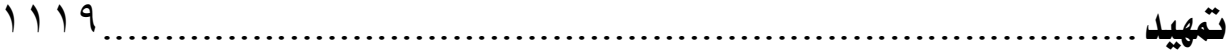

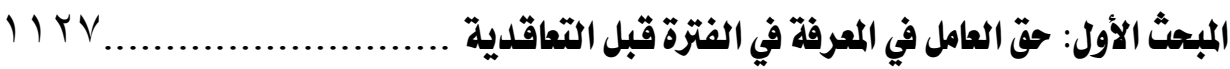

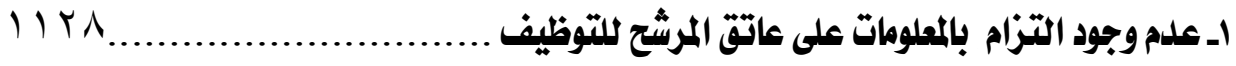

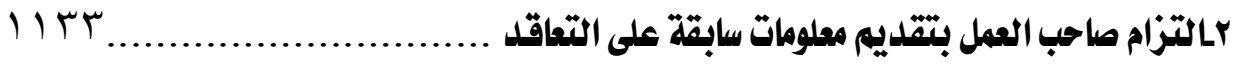

المبحث الثانى: حق العامل في المعرفة عند إبرام عقد العمل ...................................

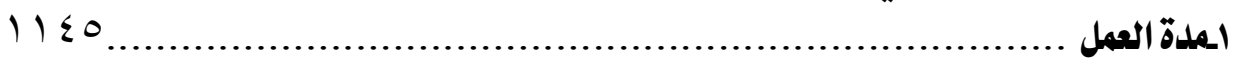

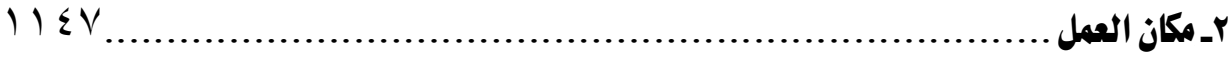

Y.

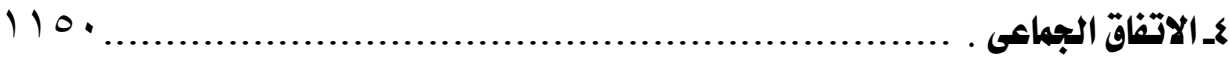

المبحث الثاثث: حق العامل في المعرفة أثناء تتفيذ عقد العمل ..................................

ا.حق العامل في معرفة التفييرات في أجره . .

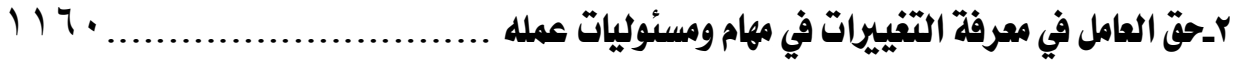

r.

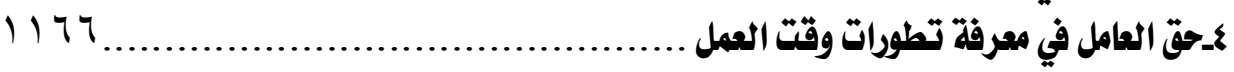

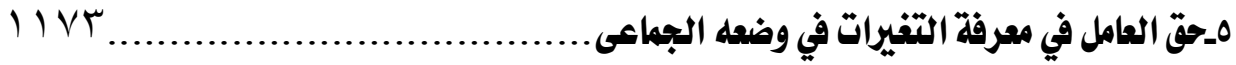

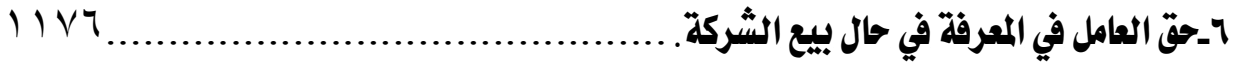

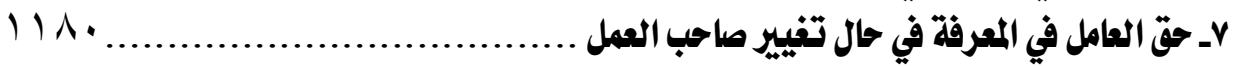

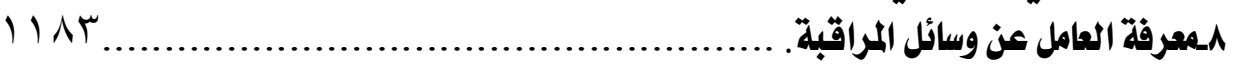

9عرفة العامل عز مخاطر العمل ................................................................

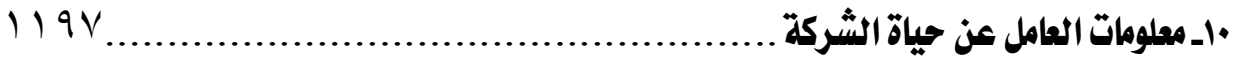

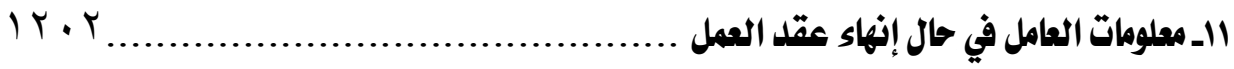

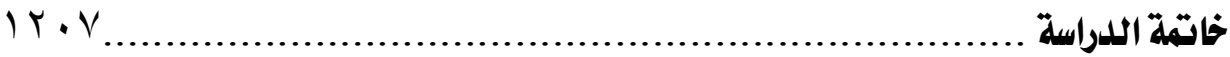

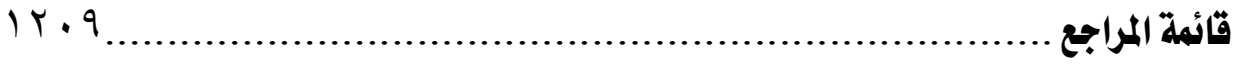

فهرس البحث....................................................................................... 